UNIVERSIDADE DE SÃO PAULO

INSTITUTO DE PSICOLOGIA

LÍVIA SANTIAGO MOREIRA

\title{
Aventura bruta em versos: sublimação e melancolia na obra de Ana Cristina César
}




\section{Aventura bruta em versos: sublimação e melancolia na obra de Ana Cristina César}

Dissertação apresentada ao Instituto de Psicologia da Universidade de São Paulo como parte dos requisitos para obtenção do título de Mestre em Psicologia Clínica.

Área de Concentração: Psicologia Clínica

Orientador: Prof. Dr. Daniel Kupermann 
AUTORIZO A REPRODUÇÃO E DIVULGAÇÃO TOTAL OU PARCIAL DESTE TRABALHO, POR QUALQUER MEIO CONVENCIONAL OU ELETRÔNICO, PARA FINS DE ESTUDO E PESQUISA, DESDE QUE CITADA A FONTE.

Moreira, Lívia Santiago.

Aventura bruta em versos: sublimação e melancolia na obra de Ana Cristina César / Lívia Santiago Moreira; orientador Daniel Kupermann. -- São Paulo, 2014.

$160 \mathrm{f}$.

Dissertação (Mestrado - Programa de Pós-Graduação em Psicologia. Área de Concentração: Psicologia Clínica) - Instituto de Psicologia da Universidade de São Paulo.

1. Psicologia clínica 2. Sublimação 3. Melancolia 4. Escrita 5. Desfusão pulsional 6. César, Ana Cristina I. Título. 
Nome: Lívia Santiago Moreira

Título: Aventura bruta em versos: sublimação e melancolia na obra de Ana Cristina César

Dissertação apresentada ao Instituto de Psicologia da Universidade de São Paulo como parte dos requisitos para obtenção do título de Mestre em Psicologia Clínica.

Aprovado em:

Banca Examinadora:

Prof. Dr. Daniel Kupermann Instituição: USP

Julgamento: Assinatura:

Prof. Dr.a Ana Cleide Guedes Moreira Instituição : $\underline{\text { UFPA }}$ Julgamento: Assinatura:

Prof. Dr. Nelson da Silva Jr. Instituição: USP

Julgamento: Assinatura: 


\section{DEDICATÓRIA}

À Ana Cecília Carvalho, Elisa Massa, e Mariana Camilo, com admiração e amizade.

À Sandra Godinho Santiago, pela poesia. 


\section{AGRADECIMENTOS}

Ao Prof. Daniel Kupermann, não só pelo apoio neste trabalho, mas também por abrir meus horizontes e pela generosidade ao ensinar;

Aos Profs. Ana Cecília Carvalho, Ana Cleide Guedes Moreira, Elisa Cintra, Maria Lívia Moretto e Nelson da Silva Junior, por compartilharem seus conhecimentos e acompanharem minha trajetória.

Ao Prof. Luís Cláudio Figueiredo, pelas preciosas indicações bibliográficas.

A Daniel Delouya, pela escuta cuidadosa e diferenciada.

Aos Prof.s da Universidade Federal de Minas Gerais, Antônio Teixeira, Cassandra Pereira, Guilherme Massara Rocha, Maria Teresa Carvalho , Paulo César Ribeiro Carvalho, Oswaldo França Neto e Riva Satovski, pela inspiração para a pesquisa, a clínica e a psicanálise.

Ao querido amigo e brilhante revisor Thiago Moyano, fundamental para a conclusão deste trabalho.

Aos queridos amigos de sempre: Ana Paula Guilherme, Cássia Reis, Daniel Werneck, Elisa Massa, Felipe Bier, Frederico Coutinho, Júlia Dorigo, Júlia Goyatá, Kirlian Siqueira, Letícia Barreto, Maria Luisa Freitas, Mariana Camilo de Oliveira, Mário Corra, Marina Maria, Mônica Toledo, Patrícia Lúcio, Paulo Henrique Amaral, Rafael Prosdocimi, Raul Duarte, Theo Duarte, Viviane Andrade, Vitor Duarte, pela companhia que faz a vida ficar colorida e possível, é muito o amor que tenho por vocês!

Aos novos e indispensáveis amigos, Aline Souza Martins, Georgia Nunes, Mateus Soares, e, especialmente, Gabriela Rodrigues, que se transformaram em minha família em São Paulo.

Aos colegas e amigos de orientação, Daniel Vitorelo, Denise Goldfajn, Lucas Bulamah, Nadeje Pereira, Priscila Robert, Tatiana Cunha e Thiago Abrantes, pela animada interlocução e pelo acolhimento.

Às indispensáveis Cecília Gontijo Leal, Julia Faria Campos, Letícia Moreira e Mariana Theodorica, pelo amor praticamente incondicional.

À família Santiago e à família Moreira, por tudo, sempre.

A Rodolfo Moreira Neto e Ana Dalva, Sandra Godinho e João Motta, por todo cuidado, carinho e leveza.

Aos meus queridos irmãos, Guilherme e Leandro, pela cumplicidade e pela alegria que trazem pra minha vida: Marininha, Bruninho e a esperada Gabriela.

Aos alunos e pacientes que tanto me ensinaram. 


\section{RESUMO}

Para abordar nossa pergunta "como se dá a sublimação na melancolia", tomaremos a escrita como modelo sublimatório, acreditando que ela demonstraria, com maior nitidez, os mecanismos que buscaremos descrever. Escolhemos como objeto de nossa investigação teórica, a obra de Ana Cristina César - artista carioca, ícone da poesia dos anos 70 no Brasil. A particularidade de sua escrita é o entrelaçamento com sua vida, cuja autobiografia ficcional traz o que acreditamos ser um discurso melancólico. Através de uma leitura sistemática do legado literário e biográfico da autora, cuja escrita transitou entre cartas, poemas, diário e tradução, investigaremos os enlaces e desenlaces entre sublimação e melancolia. Faremos um exame apurado da metapsicologia freudiana da melancolia, do conceito de desfusão pulsional e da sublimação, tentando entender a relação entre as dimensões tópica, dinâmica e econômica. A fím de melhor atingir nossos objetivos traçados, buscamos nosso aporte teórico também nas obras de autores pós-freudianos que se dedicaram ao tema, como, por exemplo, Klein, Winnicott, Lambotte e Rosenberg. Foi realizada uma análise, observando a singularidade da pesquisa que inclui o campos da literatura e da psicanálise. Descobrimos que o processo sublimatório, quando faz uso do "trabalho de melancolia", e não do trabalho de luto, aumenta o risco de desfusão pulsional. A partir da investigação da dimensão temporal e das instâncias ideais que possuem características próprias na melancolia, observamos que há uma especificidade da sublimação nesta afecção.

Palavras-chave: 1. Psicologia clínica 2. Sublimação 3. Melancolia 4. Escrita 5. Desfusão pulsional 6. César, Ana Cristina. 


\begin{abstract}
MOREIRA, L.S. Unfinished adventure in verse: sublimation and melancholy in the literature of Ana Cristina Cesar. 2014. 200f. Dissertação (Mestrado) - Universidade de São Paulo, São Paulo, 2014.

In order to better approach our central question, "how the sublimation occurs in melancholy", we are going to take writing as a sublimatory model, which pointedly demonstrates the mechanisms that we will try to describe. We have chosen as object of analysis for this theoretical investigation, the work of Ana Cristina César, artist from Rio de Janeiro, iconic in Brazil's 1970s poetry. The particularity of her writing is the intertwining with her personal life, whose fictional autobiography surfaces what we believe to be a melancholic discourse. Through a systematic reading of the author's literary and biographical legacy, which covers a variety of genres and forms, such as collections of poetry, diaries, as well as translations, we will persecute the connections and outcomes in the processes of sublimation and melancholy. We are going to do an acute examination of the Freudian metapsychology of melancholy, the concept of pulsional defusion as well as sublimation, in an attempt to understand the relationship between the topic, dynamic, and economic dimensions. Such achievements will not be possible without the contributions of post-Freudian scholars, such as Klein, Winnicott, Lambotte, and Rosenberg, whose works will be our theoretical apparatus. Our analysis observed the particularity of the researche that embrace both the fields of psychology and literature. We have reached the conclusion that when the sublimatory process uses the "work of melancholy", not grief, the risk of pulsional defusion increases. Through the investigation of the temporal dimensions and the ideal instances that possess proper characteristics in melancholy, we observed that there is a specificity of sublimation in this condition.
\end{abstract}

Keywords: 1. Clinical Psychology; 2. Sublimation; 3. Melancholy; 4. Writing; 5. Defusion; 6. César, Ana Cristina. 


\section{Sumário}

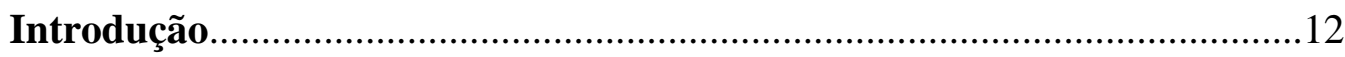

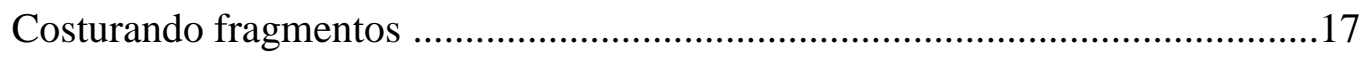

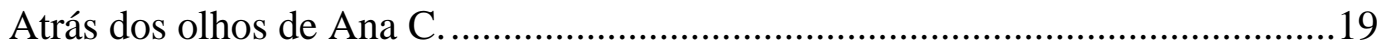

Capítulo I - A sublimação...............................................................................27

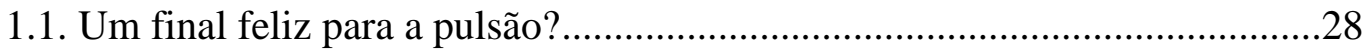

1.2. Notas sobre o risco de uma desfusão pulsional ...........................................41

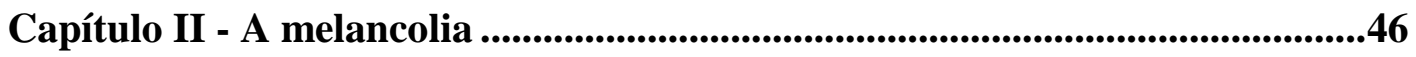

2.1. À guisa de uma introdução à melancolia....................................................46

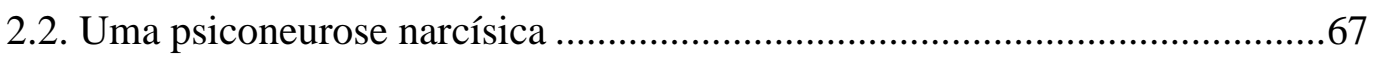

2.2.1. Ambivalência, culpa, vergonha e masoquismo ......................................74

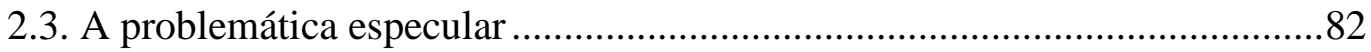

2.3.1. Os mecanismos defensivos da melancolia ............................................85

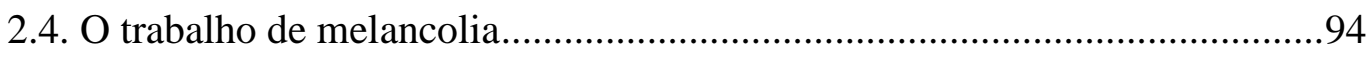

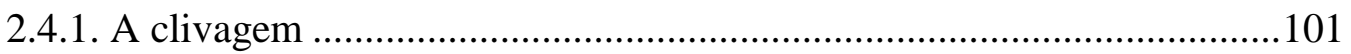

\section{Capítulo III- Ampliando a visão}

3.1. Contribuições Kleinianas: posição depressiva, sentimento de culpa,

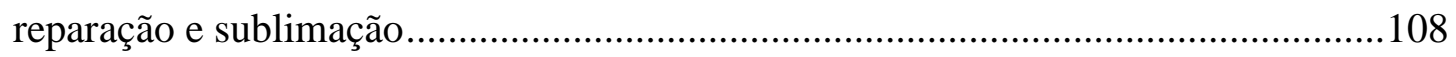

3.2. Contribuições Winnicottianas: a criatividade, o núcleo silencioso do eu e o rosto como espelho 
Capítulo IV - Imóvel tóxico do tempo: melancolia e sublimação em

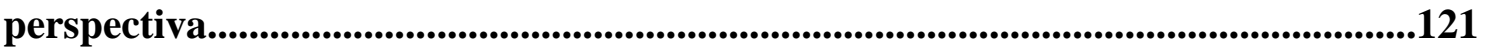

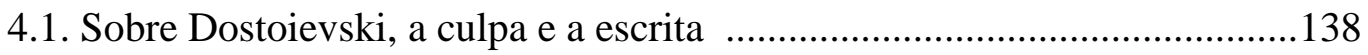

\section{Capítulo V - No entre-lugar do eu: a obra de Ana Cristina César}

5.1. No interior da palavra. 141

5.2. Preciso voltar aos cadernos terapêuticos..................................................151

5.3. Quem escreve deixa um testemunho 161

Considerações finais .169

Anexos:

Desenhos - Portsmouth-Colchester.

Dentro da "Pasta Rosa" 175

Bibliografia. 
Sete chaves

Vamos tomar chá das cinco e eu te conto minha grande história passional, que guardei a sete chaves, e meu coração bate incompassado entre gaufrettes. Conta mais essa história, me aconselhas como um marechal do ar fazendo alegoria. Estou tocada pelo fogo. Mais um roman à clé?

Eu nem respondo. Não sou dama nem mulher moderna.

Nem te conheço.

Então:

É daqui que eu tiro os versos, desta festa - com arbitrio silencioso e origem que não confessocomo quem apaga seus pecados de seda, seus três monumentos pátrios, e passa o ponto e as luvas.

Ana $C$

A teus pés, 1982 


\section{Introdução}

Meu amor águas

Naufrágil

Ana $C^{l}$

Esta pesquisa é fruto de inquietações trazidas pelos projetos de pesquisa "A sublimação e seus limites" e "Uma investigação do espaço literário", orientadas pelos professores Ana Cecília Carvalho, Guilherme Massara Rocha e Oswaldo França Neto. Estendendo-se ao longo dos anos de 2004 a 2008, ela foi financiada pelo CNPQ e FAPEMIG. No Curso de Especialização em Teoria psicanalítica da Universidade Federal de Minas Gerais, sob orientação da Profa. Ana Cecília Carvalho, defendemos nossa monografia "Sublimação e melancolia na constituição do eu" (2010). A investigação sobre os limites da sublimação continua a colocar em questão algumas das concepções que temos sobre o fazer artístico. Uma imersão nos escritos da poeta Ana Cristina César nos levou pensar que ainda haveria muito a ser pesquisado sobre o efeito do processo criativo no artista e no fruidor.

A psicanálise, através do conceito de sublimação, nos permite dessacralizar as obras de arte uma vez que sabemos a 'origem bastarda' da sua criação. As grandes descobertas da psicanálise, o inconsciente e a sexualidade, não excluiram o processo criativo de uma análise. A arte parecia ser o último reduto excluído da luta de forças entre as pulsões, da sexualidade e da ferida narcísica que o homem sofreu com a noção de inconsciente: não somos senhores de nossa própria casa. A possibilidade de análise de um artefato cultural, ao contrário do que se pensa, não interfere no valor nem na capacidade que elas têm de nos afetar. A compreensão de que a sexualidade e seus derivados podem se infiltrar em todos os lugares, inclusive ou principalmente nas artes, nos mostra a luta contínua entre pulsão, de vida e de morte, o caráter particular da pulsão - perversa e polimorfa - e a primazia do outro no surgimento do aparelho psíquico. Freud (1914/1987, p.221) nos diz:

${ }^{1}$ (CÉSAR, 2008, p.178). 
O psicanalista sabe que está trabalhando com forças altamente explosivas e que precisa avançar com tanta cautela e escrúpulo quanto um químico. Mas quando foram os químicos proibidos, devido ao perigo, de manejar substâncias explosivas, que são indispensáveis, por causa de seus efeitos?

Os elementos para a alquimia de nosso trabalho apresentam dificuldades no manejo destas "substâncias explosivas". Investigar a sublimação e a melancolia é pisar em um terreno não muito seguro, já que ambos dão margem a diversas interpretações. Além disso, a interface entre psicanálise e literatura deve acontecer de forma que os dois campos sejam enriquecidos, como se houvesse uma "fertilização recíproca da psicanálise com a arte” (KON, 1996, p.208). É preciso atenção e sensibilidade para garantir que não haja excessos nem para um lado - como as interpretações que retiram toda a subjetividade do autor, onde este está morto e só a escrita fala - nem para outroque hiper-interpreta o texto, considerando-o uma tela de projeção autobiográfica, ignorando os elementos de transformação e criação que o texto possui.

Carvalho (2001) ressalta a importância da psicanálise para definir os limites e pensar a interação entre vida e obra, principalmente nos artistas que se mantiveram muito próximos das experiências vividas que alimentaram sua escrita - que aqui tomamos como paradigma da sublimação. Antes de buscar delimitações, nos manteremos no limiar que permite a aproximação a esta área esfumaçada entre sujeito e objeto, onde não sabemos o que cria a escrita, como ela é criada e qual seria o efeito da escrita para aquele que a criou. Acreditamos que a particularidade da escrita que encontramos nos textos de Ana C., por se tratar de uma autobiografia ficcional, nos coloca ainda mais próximos dos elementos que compõem o complexo melancólico e a atividade sublimatória. Carvalho (2001, p.260) esclarece:

se é verdade, portanto, como pretende uma certa tendência da crítica literária, que o eu que fala no texto, ao ser incessantemente inventado, composto e recomposto, assumindo posições diversas e nomes que se multiplicam e se reduplicam, não pode ser equivalente à pessoa do escritor, isto apenas ressalta a necessidade de se examinar a função que a escrita teria para aquele que escreve, especialmente aqueles que terminaram a vida com o suicídio. Nesse sentido, é importante investigar os relativos distanciamentos e aproximações que movimentam a produção textual da fonte que a originou, a fim de que esse exame possa nos revelar algo a respeito da potencialidade ao mesmo tempo funcional e disfuncional da escrita. É aqui que a psicanálise pode ser convocada para ajudar a esclarecer a natureza desses limites, que dizem respeito à função da escrita como sublimação e à especificidade da poética auto-biográfica, definida 
aqui, como trabalho de fertilização cruzada, não só entre vida e escrita, mas também entre textos que são escritos e reescritos, em que a vida é rememorada, desmembrada e ficcionalizada: trabalho de reconstrução e desconstrução, no qual se vislumbra uma destrutividade potencial. ${ }^{2}$

O discurso melancólico que escutamos no texto de Ana C. - nos leva a investigar como se dá o processo da criação artística para quem a vida ficou muito "perigosa para viver”. Por apoiar-se naquilo que está nas origens do aparelho psíquico - a linguagem e a capacidade representacional -, a literatura iluminará o percurso que irá responder nossa maior questão: qual seria o estatuto da sublimação na melancolia? Acompanhamos Metzger e Silva Jr. (2010) em suas análises sobre o tema. De acordo com eles,

\begin{abstract}
A escrita literária parece exigir do sujeito um grande esforço de abstração. Seu 'material de trabalho' é particularmente abstrato, isto é, afastado de suportes empíricos, se comparado às outras artes, como a música, dança pintura e teatro por exemplo. Esse material, particularmente na poesia do séc. XX é o próprio 'eu do escritor, que deve ser tomado 'como um objeto'”. Talvez esta exigência de uma extrema renúncia erótica, associada ao reinvestimento o Eu fundado na libido narcísica sejam particulares à metapsicologia da criação literária. Tal metapsicologia é, sem dúvida, próxima àquela da melancolia. A desfusão pulsional inerente a este tipo de sublimação, desabilitaria, nesse caso, psiquismo para uma refusão completa da pulsão de vida com a pulsão de destruição, como no caso aventado por Freud na carta à Marie Bonaparte da investigação. ${ }^{3}$ Pelo contrário, em tal situação de cultura pura da pulsão de morte, o funcionamento da palavra enquanto representação-coisa poderia levar o desejo de negação ao seu extremo, isto é, à concretização suprema do "não" no ato suicida, tal como encontramos na biografia de alguns poetas e escritores com intensa produção literária. Aqui temos uma hipótese metapsicológica do que pode estar em jogo em casos como esses. (p. 579, grifos nossos)
\end{abstract}

Em consonância com estes autores compreendemos que exista uma proximidade, uma relação muito íntima entre a metapsicologia da sublimação - a escrita,

2 Ana Cecília Carvalho, em A Poética do suicídio em Sylvia Plath (2003), parece lançar luz sobre a delicada relação entre a vida, escrita e suicídio não só em Plath, mas também em outros artistas como David Foster Wallace e Ana Cristina César.

${ }^{3}$ Nesta carta analisada pelos autores, encontraremos a hipótese freudiana sobre uma sublimação da pulsão de morte. 
particularmente - e da melancolia. Destacamos as noções de identificação narcísica, os ideais, o trabalho do luto e a fusão e desfusão pulsionais na problemática em questão. $\mathrm{O}$ eu é quem recolhe a libido investida no objeto e, é pelo eu que esta libido passará ao ser sublimada. Temos aí colocados os termos de nossa investigação freudiana, a qual buscará subsídios teóricos na psicanálise e na literatura.

Onde na primeira tópica acreditávamos que o aparelho psíquico havia encontrado um destino menos conflituoso para satisfazer a exigência da pulsão, constatamos que, também na via sublimatória, pode-se ver as marcas da pulsão de morte. Diante da consequência do descentramento radical apresentado pela formulação da pulsão de morte $^{4}$, percorreremos os momentos em que o trabalho de sublimação do ego resulta em uma desfusão dos instintos e numa liberação dos instintos agressivos no superego, como no fenômeno do sentimento inconsciente de culpa - presente tanto na melancolia como na reação terapêutica negativa.

A melancolia foi uma afecção central para Freud pensar o narcisismo e, em decorrência disso, alterar sua teoria das pulsões. Assim como o caso do "Homem dos Lobos" nos alertou para a presença dos mecanismos de defesa pertencentes aos três eixos diagnósticos - neurose, perversão e psicose -, a melancolia também requer, para sua investigação, uma capacidade de ver o apagamento da linha divisória entre neurose e psicose. A nitidez dos limites desaparece com a manifestação de sofrimentos e sintomas que ora se parecem com um, ora com outro. Com Freud, consideramos a melancolia como uma psiconeurose narcísica e, assim como ele aponta em "Luto e Melancolia" (1917[1915]), existem muitas perguntas que ainda precisam ser respondidas. Gostaríamos de nos aproximar da melancolia de forma que, devido a sua patoplastia, não seja absorvida pelas outras entidades nosográficas.

$\mathrm{Na}$ melancolia a perda do objeto de amor primordial, apesar de fazer parte do desenvolvimento psíquico de todos, passa a ter uma consequência diferente daquela que a entende apenas como a primeira castração; a qualidade da relação de objeto anterior à separação será determinante no modo de enfrentamento dessa dolorida divisão, desse afastamento. A melancolia estaria relacionada ao traumatismo de uma abrupta separação, nesse primeiro momento onde o pequeno sujeito já esboça o mundo exterior

\footnotetext{
${ }^{4}$ Segundo Joel Birman, a pulsão de morte seria responsável por um terceiro descentramento efetuado pela teoria psicanalítica, tendo sido o primeiro, a noção de inconsciente e o segundo, a noção de narcisismo. In: BIRMAN, J. Freud e a filosofia. Rio de Janeiro: Jorge Zahar Editor, 2003.
} 
e este é investido como algo separado de si. A dor dessa perda está relacionada com a dor de existir, de saber-se sozinho no mundo.

Para nos aproximar cada vez mais da problemática da melancolia e da sublimação envolvidas em nosso trabalho, iremos aprofundar a análise sobre o "trabalho de melancolia", que foi definido por B. Rosenberg (2003, p.143) como uma "tentativa de liquidar o investimento narcisista do objeto", mas considerando que é ele que permitiria um deslocamento sobre outro objeto, "mesmo que este último seja sempre investido de modo narcisista".

Perseguiremos as respostas sobre como é possível ao melancólico criar. Qual o efeito do trabalho criativo numa subjetividade com "transtornos narcísico-identitários" (ROUSSILLON, 2011; FIGUEIREDO, 2014), especificamente, os melancólicos? Haveria uma especificidade na dinâmica sublimatória do sujeito melancólico? A arte seria para esse sujeito uma solução reparadora de seu eu, permitiria modos mais livres de organização ou pelo contrário, seria promotora de sofrimento subjetivo? A literatura moderna levaria o eu a um ponto de indizível do qual não seria mais possível o retorno, ou seria através dessa promoção da indeterminação e do fragmentário que se poderia constituir um vazio em torno do qual o sujeito poderia construir o novo, se refazer, mesmo que de modo transitório? Investigaremos se seria o objetivo ou o efeito da sublimação a criação de um espaço vazio dentro do sujeito, para que ele não sucumba ao mortífero da estagnação, na determinação invariável de si. Nos questionaremos se esse mesmo espaço seria, paradoxalmente, o extremo da desconstrução que não encontraria mais equivalência no mundo, significando para o sujeito um deserto, um exílio. Essa economia paradoxal será encontrada ao longo de todo o nosso trabalho.

Observaremos na obra de Ana C. assim como em seus contemporâneos, uma escrita que problematiza o público e o privado, que ficcionaliza o íntimo e o confessional - um registro da experiência de fragmentação do homem moderno. Apesar de um "espírito do tempo" em comum, acreditamos que a consequência da escrita para essa artista tenha nuances específicas importantes para pensarmos as diversas modalidades de sublimação, bem como o efeito da criação sobre um eu melancólico.

Na próxima sessão, delinearemos o percurso escolhido para melhor apresentar as questões centrais desse trabalho. 


\section{Costurando fragmentos}

Junto a esta introdução, faremos uma primeira inserção na vida e obra de Ana Cristina César. Nesta breve apresentação da autora, intitulada "Atrás dos olhos de Ana C.", traremos à tona os termos que serão discutidos ao longo da dissertação através de um ensaio com as possíveis interpretações sobre a função e o efeito psíquico da escrita para a poeta.

Na sequência, em "A sublimação", primeiro capítulo deste trabalho, retraçaremos o caminho desta noção na obra freudiana, aqui subdividida em dois momentos. Primeiramente, "Um final feliz para a pulsão?" apresenta as primeiras discussões que o fundador da psicanálise aponta em seus ensaios. Já em "Notas sobre o risco de uma desfusão pulsional", buscamos entender as alterações sofridas com o advento da segunda teoria pulsional. Ademais, trechos selecionados da obra de Ana C serão incluídos a fim de, aos poucos, familiarizar o leitor com o estilo e o conteúdo de sua escrita.

O segundo capítulo, "A Melancolia”, foi estruturado da seguinte maneira: para que se prepare o campo, “À guisa de uma introdução à melancolia" tem por objetivo discorrer sobre alguns conceitos chave, fundamentais na elaboração de um pensamento sobre tal afecção. Entre eles estão o narcisismo, as instâncias ideais e a noção de desfusão pulsional, retomada mais a frente.

Subsequentemente, em "Uma psiconeurose narcísica", iremos buscar os primeiros momentos em que Freud abordou a melancolia até chegar ao texto clássico escrito em 1915 e publicado em 1917, "Luto e melancolia". No entanto, será em "O ego e o id" (1923) que encontraremos os subsídios para o aprofundamento da constelação de conceitos que fazem parte do universo da melancolia (e da sublimação), tais como a identificação, ambivalência, culpa, vergonha e masoquismo.

$\mathrm{Na}$ "Problemática especular", acompanharemos a leitura que Lambotte (1997) faz do “estádio do espelho de Lacan”, objetivando compreender a importância dos primeiros momentos da constituição subjetiva. Desta feita, em "Trabalho de melancolia", à luz de Rosenberg (2003), lidaremos com a possibilidade de articular a problemática melancólica através da noção de "destacabilidade do objeto". Assim, retomaremos a 
discussão sobre o superego, a fusão e desfusão pulsionais, o sentimento inconsciente de culpa, o masoquismo, bem como sobre a clivagem, elementos que possuem singularidade nessa patologia. Para tal, buscaremos suporte para nossas argumentações nos autores pós-freudianos, tais como Lambotte, J. Lacan, Ferenczi, Kupermann, Rosenfeld, Vertzman, Cintra, Moreira, Green, entre outros.

Imbuídos de uma consciência sobre a complexidade do tema, o terceiro capítulo, "Ampliando a visão", convoca as contribuições de Melanie Klein e D. Winnicott na expectativa de avançarmos no debate em torno da sublimação na melancolia. ${ }^{5}$ Discutiremos brevemente, então, a análise que Freud (1928[1927]) fez do escritor Fiódor Dostoievski.

"Imóvel tóxico do tempo: melancolia e sublimação em perspectiva", quarto capítulo desta dissertação, pensará, sob os auspícios dos debates anteriores, na dimensão do tempo, fator que acreditamos ser fundamental no entendimento da desfusão pulsional tanto na melancolia quanto na sublimação.

Finalmente, nosso último capítulo, "No entre-lugar do eu: a obra de Ana Cristina César", se debruçará, com os recursos metapsicológicos adquiridos ao longo desta trajetória, sobre o trabalho da poeta Ana Cristina César. Esperamos encontrar elementos que nos permitam tensionar e iluminar a teoria até então conhecida sobre os limites da sublimação, bem como sua participação na construção ou no desencadeamento de uma melancolia.

As páginas conclusivas deste texto revisitarão nossa hipótese em busca de traçar considerações finais e possíveis questionamentos a serem perseguidos, tanto em relação a este arcabouço teórico, quanto no que tange à fortuna crítica da autora

\footnotetext{
${ }^{5}$ Neste trabalho buscaremos fazer um exercício do que é chamado por Luis Cláudio Figueiredo de um pensamento complexo em psicanálise que, ao invés de subtrair a contribuição de uma escola psicanalítica em função de outra, busca-se os pontos em que cada uma delas irá suplementar a outra, e assim, tentar compreender as múltiplas facetas do fenômeno clínico que sustenta nossa atividade teórica.
} 
Atrás dos olhos de Ana C.

Ana Cristina César, poeta carioca nascida em 1952, é um ícone da poesia marginal brasileira, do movimento de contracultura dos anos 1970, herdeira de uma tradição poética que vai de Mallarmé, Baudelaire, Whitman, Dickinson, até T.S Eliot, Mansfield, Plath, Bishop, Bandeira e Drummond. A poesia chamada "confessional", ou autobiografia ficcional era um modelo no qual ela se encontrou e trabalhou para imprimir seu estilo.

A literatura aparece muito cedo na vida de Ana C. Filha de um editor de revista e de uma professora de literatura, aos quatro anos, antes mesmo de saber escrever, ela já fazia poemas que foram ditados e registrados por sua mãe. Ela andava de um lado para o outro do sofá recitando poemas enquanto sua mãe os escrevia. Aos sete anos teve seu primeiro poema publicado. Ana C.(1992, p.82) nos conta:

eu era menina e já escrevia memórias, envelhecida. O tempo se fazia ao contrário. De noite não dormia enquanto meus olhos viam as luzes dos automóveis velozes no teto. Quando me virava de bruços vinha o diabo e me furava as costas com o punhal de prata. As Mãos se interrompiam à meia-noite quando chegava o anjo mais escuro que $o$ silêncio.

O tempo se fazia ao contrário, "o tempo é a economia de uma escrita". (DERRIDA, 1995, p.220).

Armando Freitas Filho - amigo íntimo de Ana C. e também escritor - nos fala que Ana C. encarava a modernidade e "talvez por isso tenha morrido cedo - pura passagem permanente - muitas asas e um desdém pelo que poderia ser raiz" (1998) ${ }^{6}$.

O projeto literário de Ana C. aparece enunciado no poema que se intitula "Estou atrás". O título alude tanto a uma busca quanto a uma posição - estar atrás do espelho da palavra.

\footnotetext{
${ }^{6}$ Armando Freitas Filho foi o depositário do acervo de Ana C., por vontade expressa da poeta. Junto à família, um ano após a sua morte, começa a organizar o primeiro arranjo desse material que será publicado como Inéditos e dispersos (1998), livro onde encontramos na contracapa a frase por nós citada.
} 
Estou atrás

Do despojamento mais inteiro

Da simplicidade mais erma

Da palavra mais recém-nascida

Do inteiro mais despojado

Do ermo mais simples

Do nascimento a mais da palavra ${ }^{7}$

A busca pelo ideal literário de se aproximar do ponto de nascimento a mais da palavra irá cobrar um preço alto. Chegar perto do a mais do nascimento da palavra é buscar aquilo que está para lá deste. Buscar esse além implica fazer morrer a palavra para que depois ela possa renascer. Como Ícaro que voou perto demais do sol e teve derretidas suas asas feitas de cera de abelhas e penas de gaivotas, a poeta talvez tenha ultrapassado o ponto do limite que garantiria a sua integridade. Ir além desse ponto é arriscar a queda mortal. Existe uma radicalidade na poesia de Ana C., sendo essa, talvez, a marca que a distanciava de seus companheiros de geração. Sua poesia se assemelha a uma escrita confessional e autobiográfica, mas a poeta nos avisa: “Literatura não é documento" (1979) ${ }^{8}$. Quais teriam sido os efeitos desse modo especial de literatura que produz uma "autobiografia ficcional"?

Ana C. trabalhou intensamente para buscar uma voz própria em sua escrita. A voz encontrada é capaz de seduzir o leitor a sentir-se muito íntimo, quase cúmplice e testemunha de uma história de paixão e, também, de silêncios. Sua escrita ficcionalizava o confessional e a autobiografia, confundindo seu leitor que acredita fazer parte do diálogo ao qual a escritora convida, ao mesmo tempo em que se esquiva. Vida e obra parecem a todo tempo se confundir. Talvez Ana C. tenha trazido à superfície do corpo do poema a experiência radical do encontro com o não sentido ${ }^{9}$. O ficcional terminaria por revelar-se: a verdade seria uma ficção.

De acordo com Lambotte (1997), o eu do melancólico teria sido presa das pulsões de morte que não foram suficientemente neutralizadas por falta de uma energia erótica em quantidade suficiente. O ferimento narcísico não torna possível o represamento da libido, escoando pelo buraco vazio que aparece no lugar da imagem integrada do corpo, a qual deveria ter sido oferecida pelo outro. A dinâmica aqui se parece com a "imagem

\footnotetext{
${ }^{7}$ Poema escrito em 28-05-69. (CÉSAR, 1998, p.51,)

${ }^{8}$ Título do ensaio publicado em 1979, resultado da pesquisa realizada durante o curso de mestrado em comunicação na UFRJ. (CÉSAR, 1999).

${ }^{9}$ A palavra sentido aqui pode ser entendida tanto como percepção quanto como direção e significado.
} 
da bomba aspirante que se nutre paradoxalmente do vazio que ela mesma provoca", que nos fala Lambotte (1997.p.63).

Pensamos, com a autora, que "a imagem do corpo se constrói na relação identifica tória com o outro e na caução que este traz à experiência que a criança atravessa" (LAMBOTTE, 1997, p. 205). Observamos no sujeito melancólico:

um comportamento destinado a evitar, não o objeto como tal, mas a ilusão de identidade que ele supõe e da qual o sujeito jamais se tornou cúmplice. Ou seja, à falta de uma imagem especular suficientemente investida, o melancólico se esforçaria em atenuar esta falha de ilusão ou de imaginário- e, por isso mesmo, de desejo - negando vigorosamente tudo o que se assemelharia a logro e mentira, frente a uma verdade encontrada muito cedo: a da irredutível ficção que define o sujeito. (1997, p.207, grifos no original)

Ana C. parecia buscar uma maneira de se defender dos efeitos que sua própria poesia produzia em si. Os poemas de títulos sugestivos, como "O último adeus I", "O último adeus II", "O último adeus III", "Contagem regressiva", "Nada, Esta espuma", e "Fogo do final" - sendo este o último poema de A teus pés(1982/1992) - são contrapostos ao que ela chamou de "cadernos terapêuticos". Ela escreve:

Preciso começar de novo o caderno terapêutico.

Não é como o fogo do final. Um caderno terapêutico é outra história. É deslavada. Sem luvas. Meio bruta. É um papel que desistiu de dar recados. Uma imitação da lavanderia com suas maquinas a seco e suas prensas a vapor. Um relatório do instituto nacional do comércio, ríspido mas ditoso, inconfessadamente ditoso. Nele eu sou eu e você é você mesmo. Todos nós. Digo tudo com ais à vontade. E recolho os restos das conversas, ambulância. Trottoir na casa. Umas tantas cismas. O terapêutico não se faz de inocente ou de rogado. Responde e passa as chaves. Metálico, estala na boca, sem cascata. E de novo.(CÉSAR, 1982/1992, p.53)

É interessante o que a poeta aponta aqui: haveria dois tipos de escrita, uma mais próxima do "fogo do final" e outra, mais próxima da contenção. Como indicou Carvalho (2003), haveria uma escrita pulsional e uma escrita do recalque. Entendemos, desse modo, que os cadernos terapêuticos teriam a função de curar aquilo que a própria escrita (pulsional) teria provocado. Três meses antes de sua morte, Ana Cristina 
pergunta em um poema: “a poesia pode esperar?” (CÉSAR, 1998, p.175) ${ }^{10}$ A resposta vem em outro poema escrito no mês seguinte: "Não, a poesia não pode esperar" (CÉSAR, 1998,p.76) ${ }^{11}$. Em “Contagem Regressiva”, escrito no período de 1982 a 1983 escreve: "Os ramais piscam: 'estou cansado de todas as palavras"12. O que se entrevê aqui é que o esforço de composição poética, o qual busca uma originalidade e estilo próprio irá cobrar um preço que será pago com o próprio corpo da artista. Ana C. escreve: "Os poemas são para nós uma ferida". (CÉSAR, 1998, p.164)

De acordo com elaborações freudianas, a dor é o afeto representante da melancolia. A dor psíquica, em analogia à somática, seria como uma ferida que concentra para si todos os investimentos e esforços do corpo para que o tecido rompido seja reconstruído. A ferida narcísica que encontramos nos melancólicos seria um esgarçamento do tecido psíquico que carece de sentido para se reestruturar e se recompor. Como seria possível reconstruir, então, essa rede esburacada de sentidos? Imaginamos que o outro, ou a linguagem, através da oferta de palavras que nomeiam a experiência seria capaz de nos oferecer material para essa tecelagem. Contudo, os versos dizem:

Estas areias pesadas são linguagem.

Qual a palavra que

Todos os homens sabem?(CÉSAR, 1998, p.124)

A investigação da escrita e sua função na vida de escritoras suicidas como Ana Cristina César, e lembramos aqui também de Virgínia Wolf, Silvia Plath, Florbela Espanca, Paul Celan, David Foster Wallace, e outros tantos, nos leva a perguntar junto a Carvalho: "em vez de uma suposta precariedade da estrutura do eu, o que estaria em jogo aqui não seria a precariedade da escrita, ou seja, seus limites como recurso sublimatório?” (2003, p.170) Segundo a autora:

é forçoso relacionar a precariedade da escrita a algum conflito emocional, não é para ressaltar a "divisão do eu" ou sua suposta "condição esquizóide", e sim para mostrar que a indissociação entre a movimentação pulsional dessa escrita e o trabalho das forças defensivas que se lhe contrapõem resulta em uma tensão ligada aos

\footnotetext{
${ }^{10}$ Poema escrito em 13-06-83.

${ }^{11}$ Poema escrito em 15-07-83. Ana C. morre em 28 de outubro de 1983

12 Ana C. neste poema, como em muitos outros, toma como suas as palavras dos poetas que lê. Seu texto produz um labirinto que leva o leitor a buscar as referências aludidas, na esperança de desvendar os segredos da poeta. A referência aqui é ao poema de Manoel Bandeira chamado "Pousa a Mão na Minha Testa": Não te doas do meu silêncio: Estou cansado de todas as palavras. / Não sabes que te amo? Pousa a mão na minha testa:/Captarás numa palpitação inefável/O sentido da única palavra essencial/- Amor.
} 
limites da representação. As marcas dessa tensão estarão presentes no domínio da escrita, embora não se possa dizer que a escrita liquidará o conflito afetivo que a produziu. ${ }^{13}$

Acreditamos que a escrita de Ana C. tem o efeito de produzir um traumatismo, uma vez que a palavra fica destituída dos seus poderes de nomear a experiência. Talvez seja também por esse motivo, que ela convoca o leitor a todo o momento a ser sua testemunha. A poeta escreve:

Você se importaria de ler algo sórdido? Não, não é bem algo sórdido, pelo contrário, é uma página importante que testemunha a obsessão de registrar todos os pormenores de uma mente e todo o desenrolar da história do pensamento. Eu me curvo e me escondo ante o que escrevi ao me entregar totalmente a esta obsessão. E sinto inclusive o infeliz medo da tua leitura, mas fico subitamente feliz porque percebo que deste medo posso fazer outros textos que tematizem o medo e depois falem do texto que escrevi para aplacar o medo e dos outros textos que escrevi para aplacar os primeiros textos. (CÉSAR, 2008, p.114)

De acordo com Kupermann (2008, p.174), o processo criativo comporta um efeito de desterritorialização que pode ser sentida como um desamparo, potencialmente traumatizante. Em suas palavras,

a questão se torna mais complexa pelo fato de que os efeitos de desterritorialização promovida pelas pulsões no psiquismo tendem a ser experimentados como produtores de um estado de desamparo (Hilflosigkeit) traumatizante para as subjetividades, sendo que o paradoxo reside no fato de que esse mesmo estado de desamparo seria a condição para a criação de novos territórios existenciais.

Ou seja, uma leitura ferencziana nos indica que aquilo que teria valor traumático seria "a impossibilidade de a criança atribuir sentido à dor produzida por não encontrar

\footnotetext{
${ }^{13}$ Lendo Kristeva, a autora considera que "isso se deve ao fato de que, sendo irredutível aos sentimentos, o afeto no seu duplo aspecto de fluxo energético e de inscrição psíquica - embora fora da linguagem, traduz-se com uma extraordinária fidelidade. Como a verbalização dos afetos tem uma economia diferente da economia das ideias, ela não os torna conscientes, mas faz com que eles operem duplamente: de um lado, redistribuem a ordem da linguagem e dão origem a um estilo. Por outro lado, apresentam o inconsciente em personagens e atos que representam, na enunciação, as moções pulsionais proibidas e transgressivas". Somos lembrados ainda que, para Freud, a literatura é "uma encenação dos afetos no nível intersubjetivo (os personagens) e no nível intralinguístico (o estilo).” (CARVALHO, 2003, p.170)
} 
um terceiro capaz de testemunhar e acolher seu sofrimento. Quando há esse reconhecimento, o trauma não se torna patogênico" (KUPERMANN, 2008, p.152).

A libido necessária para a criação é a mesma que carrega a história dos caminhos percorridos dentro do aparelho psíquico com suas ligações, fixações, condensações, deslocamentos e desligamentos. Escreve Ana C.(1998, p.87):

as palavras escorrem como líquidos lubrificando passagens ressentidas.

O escritor, ao, e para, criar, precisa se aproximar daquilo que será transformado (emoções, afetos, intensidades, representações) ficando, assim, novamente confrontado com experiências que procuram sentidos e destinos. A criação e a arte podem promover uma abertura de espaços psíquicos mais livres, onde as experiências podem ser transformadas, além de serem capazes de representar algo para o artista e também para o fruidor. Contudo, como podemos suspeitar através de Ana C., o processo criativo não é sem riscos para aquele que cria, como também não o é para aquele que se utiliza dele. Pelo contrário, provoca reaberturas que podem ser traumáticas, mas que ao mesmo tempo, podem ser metabolizadas e simbolizadas. Ana Cristina César (1998, p.33) escreve:

Talvez me irrite pisar no impisável

E a morte deve ser muito mais gostosa

Recheada com marchemélou

Uma lâmpada queimada me contempla

A poesia de Ana Cristina, ao mesmo tempo em que procurou ir ao limite da palavra, também procurou se defender dos efeitos dessa escrita, através dos chamados "cadernos terapêuticos”. A esperança de que uma escrita de contenção pudesse sustentar o trabalho do que chamamos de "escrita ferida" acabou não sendo suficiente para conter o transbordamento pulsional ocasionado por ela. Lemos o poema intitulado "Fagulha" da série "Do diário, não diário- Inconfissões" (1998, p.41):

Eu não sabia que virar pelo avesso era uma experiência mortal 
A escrita de Ana C. talvez tenha fragilizado os mecanismos de defesa que poderiam oferecer uma proteção em relação à verdade mortífera do nada sobre o qual se erige a própria identidade. "Não quero mais a fúria da verdade." (CÉSAR, 1992, p.76), diz o eu da enunciação, e em outro poema: "Não volto às letras, que doem como uma catástrofe. Não escrevo mais.” (CÉSAR, 1992, p.77)

Pensamos que o encontro com o limite representacional da palavra na escrita poética levaria, assim, a um (re)encontro com o nada, espelho vazio com o qual o sujeito melancólico se depara nos primeiros tempos de sua constituição subjetiva. A "estranha familiaridade" (Unheimlich) com a dimensão necessária do engano, da ficção necessária para a identificação do eu com a imagem que lhe é atribuída pelo olhar do outro, traria à tona a dificuldade experimentada por esses sujeitos de tomar consciência de seu corpo, de seu espaço e de seus limites. Ana C., ao buscar "o nascimento a mais da palavra", encontra a própria morte da palavra, que não mais representa e nem comunica. $\mathrm{O}$ buraco aparece como um abismo que não mais possuirá contorno nem moldura. $\mathrm{O}$ risco de tal empreendimento estético é a irreversibilidade de tamanha desconstrução, uma vez que o buraco se assoma à ferida psíquica responsável por, paradoxalmente, promover o ato criativo.

Seguiremos a análise de nossa pesquisa após comentarmos o poema escrito mais de quatorze anos antes da morte de Ana Cristina César. O poema assombra o leitor que irá se deparar com o vazio produzido pela própria escrita. Vemos como ali, a função representativa da palavra é colocada em xeque, sendo que seu caráter ilusório aparece através da repetição ad nauseam da palavra "janela". A busca do ideal literário encontrou, ao fim, a palavra enquanto coisa, palavra cuja forma não garante mais o sentido. Sentido que, talvez, fosse o próprio motivo de toda a busca. Ao lermos esse poema, escrito em fevereiro de 1969, sofremos um efeito de tensão e desconstrução, resultado que ganha ainda mais intensidade através da significação que só podemos lhe dar a posteriori, após sabermos que a escritora se lançou para a morte, da janela de seu quarto:

Ela ficava olhando pela janela vertendo seu único olho pela janela com o pé em cima da janela Ela ficava olhando pela janela O dia inteiro o olho, o pé, a janela em cima embaixo pelos lados da janela 
Ela ficava olhando pela janela

um dia ela cansou de olhar e fechou a janela

mas era dura e não fechava a janela

Ela ficava olhando pela janela

às vezes tentava mas logo esquecia da janela

que sempre aberta com um olho e um pé a janela

Ela ficava olhando pela janela

até que seus pensamentos dissociaram a janela

que caiu inteiriça, e era uma caída janela

Ela ficava olhando pela janela

que não era, nem existia como janela:

Ela ficava olhando pelo buraco

(CÉSAR, 1998, p.49)

A palavra janela aparece várias vezes em sua obra, sendo um importante significante que nos remete ao dentro e o fora, à moldura, ao não lugar, ao enquadre, ao alcance da vista, à privacidade e à alteridade, ao mundo externo e ao mundo interno. De acordo com Lambotte (1997), o suicídio por defenestração (deixar-se cair ou lançar-se pela janela) é próprio da melancolia. A janela funciona como a metáfora do olhar do materno, olhar que não teria devolvido a imagem do eu que deveria ali ser refletida, depositada. "A defenestração do melancólico se assevera no impulso do sujeito de unirse o nada, que ele, desde sempre, presume subsistir atrás das coisas" (MASSA, 2012, p.86). Como desenvolveremos no segundo capítulo "A melancolia", a criança irá identificar-se com o objeto do olhar perdido de uma mãe deprimida, aquele que não reflete o que vê, mas se perde no horizonte ilimitado e não representável. 


\title{
Cap. I A Sublimação
}

A animalidade dos signos me inquieta. Versos a galope descem alamedas a pisotear-me a alma ou batem asas entre pombos pardos da noite.

Ana C. ${ }^{14}$

Na obra póstuma Antigos e Soltos (2008), olhamos, pela fresta das páginas, o processo criativo de Ana C. Testemunhamos as diversas versões de um mesmo poema, os cortes e edições, as mudanças de termos, um apagamento leve de palavra que ainda se deixa entrever, a caneta em fúria que escurece nossa visão. Em uma de suas cartas Ana C. pergunta se os seus cortes nos poemas seriam atos-falhos. Trazemos aqui um exemplo, sem a edição final que calaria os versos suprimidos, pertencente à sessão "Prontos, mas rejeitados", escrito enquanto Ana Cristina César ainda era jovem:

\author{
Metalinguagem Falida \\ Não posso não posso mais falar do ato de escrever \\ Não há mais metáforas para o ato de escrever \\ Me sinto morta ao redigir o ato de escrever \\ Me sinto __ porca ao lamber o ato de escrever \\ Se falo no poema. No sujeito do ato de escrever \\ Não há como conviver com o ato de escrever \\ Não há mais como aguentar \\ Não há como resolver o aflito ato de escrever \\ Na mãe. No desejo na paisagem nos bichos \\ Vejo apenas metáforas para o ato de escrever \\ reflexos falides problemas antiges \\ me castigo, me ausento, me evito esse problema \\ no jardim \\ ebsessivamente \\ por toda parte obsessivamente já começa \\ ocupa obsessivo metade da minha vida \\ e é preciso que obsessivo saia da outra metade \\ para dar lugar enfim ao ato de foder \\ (CÉSAR, 2008, p.108, grifos nossos, traços no original)
}

${ }^{14}$ (CÉSAR, 2008, p.22) 
As frases cortadas parecem ter uma função que não é somente estética. O que significaria para a autora os cortes serem atos falhos? Em outro poema escreve: "o desespero precisa ser discreto, soletrado numa pequena esquina (2008, p.232). O programa estético de Ana C. vai em direção ao fragmentário, ao impessoal; escrever até que não haja mais resquícios de subjetividades. Então, “como conviver com o ato de escrever ?" (CÉSAR, 2008, p.108)

É ao conceito freudiano de sublimação que iremos recorrer para entender a relação entre criação e criador, entre a sexualidade, a necessidade de refreamento da sexualidade e ao mesmo tempo, a importância da ressexualização da pulsão.

\subsection{Um final feliz para a pulsão?}

Não, amor, isto não é literatura.

Agora que você chegou não preciso mais me roubar. E como farei com os versos que escrevi?

Ostento biográficas palavras embora maneta e sem luneta. Tarde demais esse amor sem dedos.

Ana C. $^{15}$

A sublimação é um conceito utilizado por Freud para explicar o processo criativo e a capacidade do sujeito de abrir mão dos seus desejos sexuais diretos e egoísticos em função da cultura. Entretanto, ao longo da obra freudiana não encontramos um texto exclusivamente dedicado à ela ${ }^{16}$. Alguns leitores da obra freudiana consideram a sublimação apenas como uma noção, alegando que uma falta de formalização e uma forte aproximação com conceitos aos quais se misturaria - como formação reativa, sintoma, e a simbolização - não a permitiria ser elevada a um conceito. Mijolla-Mellor (2011, p.37) nos diz que a noção de sublimação ocupa uma posição paradoxal por não

15 (CÉSAR, 1998, p.181). A segunda estrofe foi escrita em setembro de 1983. A terceira estrofe está em César, (2008, p.66)

${ }^{16}$ Segundo Strachey, Freud teria destruído o artigo metapsicológico sobre a sublimação junto a outros trabalhos em 1915. (Cf.: KUPERMANN, 2003, p.65) 
ter sido totalmente definida por Freud e ao mesmo tempo ser indispensável ao edifício teórico da psicanálise, tanto do ponto de vista individual quanto coletivo.

A inquietação de Freud com a arte está presente desde as cartas à Fliess ${ }^{17}$ até os últimos textos, nos mostrando que o acertado conhecimento intrapsíquico que os escritores criativos demonstravam continuaram a trazer a compreensão interna (insight) que a psicanálise se esforçava para alcançar.

Freud declara inúmeras vezes tanto que a psicanálise não conseguiria explicar o gênio nem o artista, quanto que não caberia a ela fazê-lo. Em o "Interesse da psicanálise do ponto de vista da ciência da estética" (1913) ele nos diz:

A psicanálise esclarece satisfatoriamente alguns dos problemas referentes às artes e aos artistas, embora outros lhe escapem inteiramente. No exercício de uma arte vê-se mais uma vez uma atividade destinada a apaziguar desejos não gratificados - em primeiro lugar do artista e, subsequentemente, de sua assistência ou espectadores. As forças motivadoras dos artistas são os mesmos conflitos que impulsionam outras pessoas à neurose e incentivam a sociedade a construir instituições. De onde o artista retira sua capacidade criadora não constitui questão para a psicologia. (FREUD, 1913, p.222)

Essas assertivas freudianas sempre funcionaram como uma espécie de ressalva que permitia com que ele fizesse, com menos resistência, exatamente aquilo que havia dito não ser possível ou até mesmo permitido. Sarah Kofman (1996) nos demonstra essa tendência ao longo da obra freudiana e nos alerta para a diferença entre o que ele dizia e aquilo que fazia em relação às interpretações de obras de arte, como vemos no "Édipo Rei”, “A Gradiva”, Leonardo da Vinci, Dostoievski, entre outros. Ainda segundo a autora, podemos identificar o método desenvolvido para se aproximar da obra de arte que é fruto de inspiração e investigação.

O método freudiano consistiria em partir do efeito de afeto produzido pela obra sobre o fruidor para voltar ao afeto experimentado inicialmente pelo artista - o que nos leva a interrogar sobre os meios que foram capazes de produzir transformações de afeto neste e no fruidor. Tais meios procedem de uma combinatória simbólica que o artista domina.

\footnotetext{
${ }^{17}$ Em carta de 15 de outubro de 1897, Freud escreve para Wilhem, Fliess sobre suas descobertas sobre a interpretação do sonho e reconhece em si mesmo o fenômeno Edípico. Neste contexto, cito:

"Passou-me fugazmente pela cabeça a ideia de que a mesma coisa estaria também na base de Hamlet. Não estou pensando na intenção consciente de Shakespeare, mas creio, ao contrário, que um acontecimento real tenha estimulado o poeta a criar sua representação, no sentido de que seu inconsciente compreendeu o inconsciente de seu herói.”. (Carta 71, p.283)
} 
A arte, que é uma espécie de jogo simbólico, permite uma alteração econômica ao transformar o afeto. Em "Leonardo da Vinci e uma Recordação de infância" (1910, p.98) lemos:

Uma natureza generosa deu ao artista a capacidade de exprimir seus impulsos psíquicos mais secretos, aqueles que ele próprio não percebe, por meio das obras de arte que ele cria, e essas obras têm um efeito poderoso sobre aqueles que não conhecem o artista $\mathrm{e}$ igualmente ignoram a fonte de emoção que sentem (...). Entretanto, se considerarmos as profundas transformações pelas quais uma impressão da vida de um artista deve passar antes de estar autorizada a contribuir para um trabalho artístico, seremos forçados a manter em limites muito modestos o direito à certeza da demonstração.

A sublimação faz referência à definição química do processo definido como uma passagem direta de um corpo, sem intermédio líquido, do estado sólido ao gasoso. (LAPLANCHE, 1989, p.11). Outro sentido do termo sublimação é o que implica a passagem por um limiar ou de um "limite" (limens) (MIJOLLA-MELLOR, 2011, p.41). Limites que devemos reconhecer na economia e na dinâmica sublimatória. Trata-se de um processo onde a transformação dos elementos psíquicos vigora e o aumento de valor atribuído ao material sublimado viria da sua distância do sexual, da sua capacidade de formar laço social e parte das nossas pulsões virarem ternura. (MIJOLLA-MELLOR, 2011, p.41). Com Kofman (1996, p.186) acreditamos que apesar da noção de valor incluída no termo, a sublimação é um conceito metapsicológico e não moral.

Para Freud, a pulsão ou energia libidinal seria suscetível de transitar das atividades sexuais para as atividades não sexuais e a sua referência à valorização social nos leva a questionar se ela é determinante para definir as atividades sublimatórias. "O que está em questão será a utilidade para a sociedade, será, de modo mais profundo o reconhecimento pelo outro ou pelos outros, será o valor de comunicação e até mesmo o valor de linguagem”? (LAPLANCHE, 1989, p. 12)

Em "Os três ensaios sobre a sexualidade infantil” (1905), conhecemos o caráter perverso polimorfo da pulsão sexual. São apresentados alguns componentes da sexualidade, a qual é sempre parcial e busca uma organização. Torna-se claro como o objeto da satisfação sexual é contingente, sendo necessária uma rede de significações para unir a pulsão e o objeto. A sublimação aparece no segundo ensaio, aproximada à noção de formação reativa às fantasias histéricas e também como defesa contra o caráter do erotismo anal. (Cf. FREUD, 1905, p. 183) Aqui são apresentados três destinos para a 
sexualidade infantil - esquema parecido com o que veremos anos depois no estudo sobre Leonardo da Vinci em 1910. O recalque da disposição sexual infantil pode resultar na perversão, no sintoma neurótico e na sublimação. O sintoma seria uma obra de arte não compartilhada, ao passo que esta deve ser compartilhada. $\mathrm{O}$ recalque deveria inibir o sexual infantil, mas também deixar um resto de libido destinado à sublimação. Este mecanismo ainda não exclui o risco de que a inibição predomine.

Segundo Freud, as forças que motivam os artistas são os mesmos conflitos que se traduzem em neuroses e incentivam a sociedade a construir suas instituições. Isto é, a tentativa do mecanismo mental é a de aliviar o indivíduo das tensões nele criadas por suas necessidades, o que em parte pode se dar extraindo-se satisfação do mundo externo. Porém, para se obter satisfação no mundo real, é necessário possuir controle sobre ele. Os impulsos afetivos são regularmente frustrados pela realidade, o que leva a uma nova tarefa de encontrar meios de manejar sua insatisfação. A maneira encontrada pelo artista é representar como realizadas suas fantasias mais pessoais, plenas de desejo, mas elas só se tornarão obras de arte quando passarem por uma transformação que atenua o que nelas é ofensivo, oculta sua origem pessoal e, ao obedecerem às leis da beleza, seduzem outras pessoas com uma gratificação prazerosa.

Em "Delírios e sonhos na Gradiva de Jensen” (1906), vemos como são submetidos à investigação os sonhos das personagens criadas por escritores imaginativos no curso de uma história ficcional. ${ }^{18}$ Sobretudo, neste texto, Freud manifesta sua admiração pelos escritores e poetas que, aparentemente sem esforço, possuem um conhecimento acertado dos processos psíquicos.

Sabemos da preferência explícita pela literatura como forma de arte, especialmente pelos clássicos como Goethe e Shakespeare ${ }^{19}$. Contudo, teremos que lembrar que Freud elegeu um poeta contemporâneo a ele, Arthur Schnitzler (1986-1931), como seu “duplo" (Doppelgängerscheu). Em uma carta apaixonada ao poeta (CF. KON, 1996) escreve:

\footnotetext{
${ }^{18}$ Às voltas com a questão da arte e da criação, atento às implicações que a arte moderna teria para a psicanálise, Green questiona se a psicanálise nos modelos freudianos seria capaz de interpretar a arte moderna. (GREEN, 1971)

${ }^{19}$ Entre os autores mais citados por Freud estão: Sófocles, Heine, Ibsen, Flaubert, Rabelais, Zola, Diderot, Bocage, Oscar Wilde, Bernard Shaw, Dostoievski, Molière, Swift, Homero, Horácio, Macaulay, Tasso, Hoffmann, Schiller, Mark Twain, Aristófanes, Thomas Mann, Stefan Zweig, Hebbel, Galsworthy, Cervantes, Hesíodo, entre outros. (KOFMAN, 1996, p.28)
} 
Sempre que me deixo absorver profundamente por suas belas criações, parece-me encontrar, sob a superfície poética, as mesmas suposições antecipadas, os interesses e conclusões que reconheço como meus próprios. [...] Carta de 14 de maio de 1922. (FREUD apud KON, 1996,p.38$39)^{20}$

A carta confirma o que Baas (2001, p.115) diz: "é o artista que interessa a Freud, mais que o amador da arte, na elaboração do processo sublimatório". Entretanto, Freud está mergulhado nesse lugar de apreciador, de leitor da arte. Depois da "Gradiva", ele descobre que os sonhos inventados por um escritor serão suscetíveis às mesmas interpretações que os sonhos reais, e assim, na produção do poeta estão em jogo os mesmos mecanismos do trabalho de elaboração do sonho.

"Delírios e sonhos na Gradiva de Jensen" (1906) é um texto divisório; ali, Kofman (1996, p.59) nos diz que "Freud teria passado de uma atitude de admiração frente aos artistas para uma certa desilusão. A obra de arte muda do status de modelo paradigmático confirmador do conhecimento psicanalítico: ela própria se torna objeto de investigação." 21

Kofman (1996) nos conta um detalhe curioso da história entre psicanálise e arte. Quando se buscou um comentário de Jensen, autor da Gradiva, sobre a interpretação feita de sua obra, o autor respondeu de mau humor que as negava. O que não abalou Freud em suas convicções, ao contrário, ele diz que não há nada estranho para nós que o autor desconheça o seu próprio saber. "Mas o que pode ser o psiquismo, ele próprio, senão um texto, para poder ser "representado" por um texto? Não é só o texto da obra que estrutura a vida do escritor em um texto, ao estruturar os seus fantasmas?" (KOFMAN,1996,p.57) A conclusão que encontramos neste artigo é que:

O poeta, [...] concentra sua atenção no inconsciente de sua própria alma, aguça o ouvido para todas as virtualidades e lhes confere expressão artística, ao invés de recalcá-las pela crítica consciente. Ele aprende pelo interior de si mesmo o que nós aprendemos pelos outros: quais são as leis que regem a vida do inconsciente; mas ele não tem a menor necessidade de exprimí-las ou de percebê-las claramente; graças à tolerância de sua inteligência, elas são incorporadas às suas criações. Nós extraímos essas leis da análise de suas obras, da mesma maneira que desenredamos dos casos mórbidos reais (...) Ou ambos, o

\footnotetext{
${ }^{20}$ In: Jones, E. A vida e a obra de Sigmund Freud (Rio de Janeiro, Imago, 1989, vol.3, pp 430-431.

${ }^{21} \mathrm{O}$ conhecimento endopsíquico do artista adquirido por Freud na Gradiva mostra que o "artista não sabe verdadeiramente o que diz e diz mais do que acredita estar dizendo: Platão já expulsava os poetas de sua cidade ideal, entre outros motivos por esse." (KOFMAN, 1996, p.28)
} 
poeta e o médico, compreenderam mal o inconsciente, ou nós dois o compreendemos muito bem." (FREUD,1906,p.93)

Em "Escritores criativos e devaneios" (1907) Freud se pergunta se devemos procurar traços de atividade imaginativa já na infância. Pode-se dizer que, na brincadeira, toda criança se comporta como um escritor criativo, pois constrói um mundo próprio e reajusta os elementos de seu mundo de uma nova forma que lhe agrade. A antítese do brincar não é o que é sério, mas o que é real. A irrealidade do mundo imaginativo dos escritores permite que aquilo que presenciamos como expectadores nos cause prazer, o que não aconteceria caso fosse realidade. A fantasia criada por um escritor criativo funciona como a realização de um desejo, uma correção da realidade insatisfatória. Os desejos encontrados podem ser eróticos ou são do tipo que elevam a personalidade.

A tese que permite a comparação da criação poética como devaneio diz que uma forte experiência no presente desperta no escritor criativo uma lembrança de uma experiência anterior (infância). Essa recordação dá origem a um desejo que encontra realização na obra. A própria obra revela ocasiões motivadoras do presente e da lembrança antiga. $\mathrm{O}$ indivíduo que devaneia oculta suas fantasias dos demais porque sente ter razão para se envergonhar das mesmas, acreditando que seu relato causaria repulsa. O escritor suaviza o caráter de seus devaneios egoístas por meio de alterações e disfarces, e nos suborna com o prazer puramente formal, isto é, estético ${ }^{22}$, que nos oferece na apresentação de suas fantasias. Freud nos diz que o efeito produzido por uma obra literária é a libertação de tensão em nossas mentes, talvez porque ela permita que nos deleitemos com nossos próprios devaneios, sem autoacusações. Quando as fantasias se tornam exageradamente profusas e poderosas, estão presentes as condições para o desencadeamento da neurose. Nossos sonhos noturnos são fantasias, nos quais os desejos reprimidos e seus derivados são realizados através da distorção onírica. (CF: FREUD, 1907, p.154) Nas histórias dos escritores criativos analisados por Freud, há sempre um herói a quem nada pode acontecer.

Em uma coletânea póstuma que reúne a obra de Ana C. encontramos uma narrativa ilustrada pela mesma na qual podemos perceber, como em um movimento antecipatório, a temática do suicídio e da morte. Vemos:

\footnotetext{
${ }^{22} \mathrm{O}$ termo estético será entendido não só pela categoria do belo, mas também das sensações, como Freud descreve em "O estranho" (1919).
} 


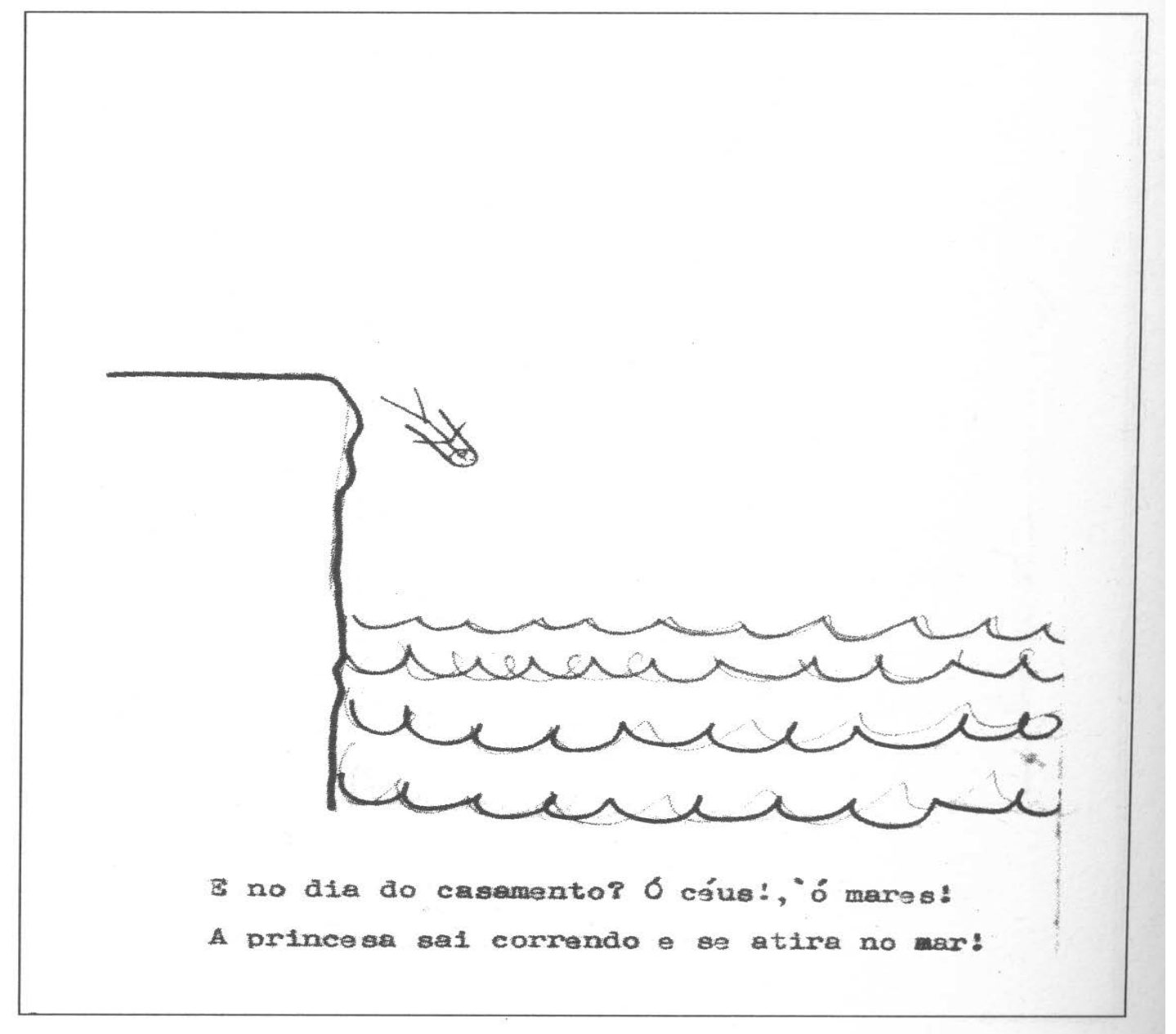

A imagem acima faz parte de uma história que foi desenhada e escrita por Ana C. ainda criança (Cf: CÉSAR, 1998, p.18). Nos chama atenção o fato de que sua primeira tentativa de suicídio foi lançando-se ao mar, por volta de um mês antes de sua morte. Ao contrário da análise que Freud faz dos escritores, na história da poeta ainda criança, não existem heróis e a princesa se atira no mar.

Em “A moral sexual civilizada e doença nervosa moderna” (1908), um eterno mal estar fica instituído, uma vez que é necessário abrir mão da satisfação imediata e sofrer a operação de mudança na relação com o objeto primordial de amor. Essa intervenção, renúncia à qual todo sujeito precisa passar para tornar-se um ser parte da cultura, implica uma retirada da libido investida no objeto, uma dessexualização e uma posterior escolha por um alvo não sexual. A entrada na cultura seria um efeito da sublimação, assim como também toda produção cultural. A capacidade de sublimação, o que levaria a alguns serem artistas ou escolher esse destino da pulsão não é totalmente esclarecida por Freud (1908, p.193) 
Esse instinto (instinto sexual) coloca à disposição da atividade civilizada uma extraordinária quantidade de energia, em virtude de uma singular e marcante característica: sua capacidade de deslocar seus objetivos sem restringir consideravelmente a sua intensidade. A essa capacidade de trocar seu objetivo sexual original por outro, não mais sexual, mas psiquicamente relacionado com o primeiro, chamase capacidade de sublimação.

É necessário o refreamento dos instintos, mas, com isso, corre-se o risco do adoecimento nervoso. O aparelho psíquico, comparado com uma máquina, só pode transformar um tanto de energia:

(...) A essa capacidade de trocar seu objetivo sexual original por outro, não mais sexual, mas psiquicamente relacionado com o primeiro, chama-se de capacidade de sublimação. (...) Entretanto, não é possível ampliar indefinidamente esse processo de deslocamento, da mesma forma que em nossas máquinas não é possível transformar todo o calor em energia mecânica. Para a grande maioria das organizações parece ser indispensável certa quantidade de satisfação sexual direta, e qualquer restrição dessa quantidade, que varia de indivíduo para indivíduo, acarreta fenômenos que, devido aos prejuízos funcionais e ao seu caráter subjetivo de desprazer, devem ser considerados como uma doença. (1908,p.153, grifos nossos)

No trabalho sobre Leonardo da Vinci, Freud (1910, p.120) nos dirá que "a repressão quase total de uma vida sexual real não oferece as condições mais favoráveis para o exercício das tendências sexuais sublimadas" Neste trabalho ele faz uma faz uma patografia - um estudo sobre a mente a partir da obra e dos dados biográficos disponíveis - do artista. A atividade de pesquisa no início da vida desse artista é interpretada por Freud como a sublimação de sua curiosidade sexual. Segundo ele, a relação muito próxima entre Leonardo e sua mãe, bem como sua origem ilegítima, teriam tido uma influência decisiva no destino do artista e sua obra:

A repressão sexual que se estabeleceu depois dessa fase de sua infância levou-o a sublimar sua libido na ânsia de saber e estabelecer sua inatividade sexual para o resto de sua vida. [...] É provável que uma outra pessoa não tivesse conseguido livrar da repressão a maior parte da libido sublimando-a numa sede de conhecimentos; sob as mesmas influências teria sofrido perturbação permanente de sua atividade intelectual ou adquirido uma disposição incoercível para a neurose obsessiva. (FREUD, 1910, p.123) 
Apesar da sublimação ter sido apontada como uma alternativa ao sintoma psíquico, vemos que as atividades sublimatórias de Leonardo da Vinci estão acompanhadas de sofrimento desde o início da vida, aparecendo na inibição de suas produções, na dificuldade de realização sexual e nos sintomas obsessivos. Dessa forma, mesmo sendo considerado como especial na sua capacidade de sublimar, Da Vinci também tinha uma "tendência especial para a repressão dos instintos" (FREUD, 1910, p.123). A sublimação não era uma forma de cura para seus sintomas.

A tendência homossexual do pintor seria um tipo de escolha narcísica de objeto que ocorreu devido à impossibilidade de aceitar a perda do vínculo libidinal com a mãe. Com o temor desta ameaça, "o menino reprime seu amor pela mãe; coloca-se em seu lugar, identificando-se com ela, e toma a si próprio como um modelo a que devem assemelhar-se os novos objetos de seu amor" (FREUD, 1910, p.92). Assim, os jovens parceiros representariam duplos de si mesmo. Neste momento da obra freudiana ainda não havia uma distinção entre autoerotismo e narcisismo.

Observa-se, neste caso, como a atividade científica ganha mais interesse que a artística com o passar dos anos, como se esta o aproximasse mais de respostas e de uma tentativa de elaboração daquilo que seriam suas investigações sexuais infantis. Eissler em seu estudo sobre Leonardo, supõe uma espécie de circuito de "evacuação do traumatismo" olho-mão, uma vez que não há uma impressão que Leonardo não deva passar imediatamente para o desenho. Assim como em uma aproximação com Goethe também haveria uma espécie de

[...] conversão imediata em verso de toda e qualquer experiência sensível, como se a poesia surgisse diretamente de todas as impressões cotidianas. Em última análise, vemos que o modelo do traumatismo é também um modelo de defesa contra o traumatismo. Defesa ou elaboração? Defesa ou simbolização?(LAPLANCHE, 1989,p.187)

Essa característica de ter que anotar tudo que via, transformar tudo em poesia, era também uma característica de Ana C., que andava sempre com um caderninho na mão.

Para Laplanche, essa "evacuação do traumatismo", mencionada anteriormente, trataria-se de uma simbolização:

De fato deveríamos conceber a elaboração artística, essa elaboração no desenho (desenho teria que se distinguir da pintura), como 
elaboração ao mesmo tempo do ataque interno e do ataque externo, do que Freud chama a excitação e do que chama ou do que se traduz por estímulo. [...]Pois bem, poder-se-ia dizer que a simbolização na obra de arte desfaz esta distinção, desfaz até a relação metafórica entre o externo e o interno. Ela reúne o externo e o interno para retomá-los num outro nível de símbolo.(LAPLANCHE, 1989,p.190)

A obra comportaria, então, essa função de elaboração, ao ser o que permite um tratamento daquilo que seria potencialmente traumático.

No estudo de 1910 há sempre uma oposição entre a sublimação artística que acontece em um tempo mais tardio - ligada à alegria de viver - e a sublimação intelectual, originária - que anima, mas também paralisa a criação artística. A “inspiração" é considerada um outro pólo da sublimação que permitiu Laplanche trilhar novas pistas sobre Leonardo. Lemos em “Sublimation ou Inspiration” (1999):

[...] a criação é como que perfurada pelo vetor de conhecimento [...] e como a criação vem do indivíduo ela é narcísica, mas isso que o chama e o orienta, é um vetor vindo do outro. [...] E tudo que o sujeito pode fazer é ficar aberto ao trauma e para o trauma. (LAPLANCHE, 1999, p.331, tradução livre)

A relação do artista com seu pai também aparece como fator importante em sua obra. Com Lage (2008) destacamos a curiosa afirmação de Freud de que essa relação seria repetida no tratamento que dava aos seus trabalhos:

Para Leonardo, o reflexo de sua identificação com o pai foi prejudicial para sua pintura. Freud entende que Leonardo tratava sua criação como seu pai outrora tratou a dele, ou seja, restabelece-se uma similaridade entre a relação do artista com o pai e a relação do filho com sua criação. Ele reconhece, também, nessa impossibilidade de concluir, a presença de "ambições enormes, difíceis de satisfazer", que podem ser a manifestação da outra face dessa identificação: o desejo de superar o pai. (LAGE, 2008, p.77)

A sublimação pode ser estimulada pelo ideal, no entanto, sua execução é independente de tal estímulo. A formação de um ideal aumenta as exigências do eu, constituindo o fator mais poderoso a favor da repressão. Freud nos mostra como somos levados a confundir a formação desse ideal e a sublimação, sendo necessária uma diferenciação entre eles. 
A idealização "é um processo que diz respeito ao objeto; por ela, esse objeto, sem qualquer alteração de sua natureza, é engrandecido e exaltado na mente do indivíduo. A idealização é possível tanto na esfera da libido do eu quanto na da libido objetal." (FREUD, 1914, p.111) Por outro lado, a sublimação “é um processo que diz respeito à libido objetal e consiste no fato de se dirigir no sentido de uma finalidade diferente e afastada da satisfação sexual" (FREUD, 1914, p.111). Somos lembrados, portanto, que o ideal do eu exige a sublimação dos instintos libidinais, mas não pode fortalecê-la.

Encontraremos aqui a formação do agente psíquico especial que compara e mede constantemente o eu real pelo eu ideal. A sublimação "é uma saída, uma maneira pela qual essas exigências podem ser atendidas sem envolver repressão" (FREUD, 1914, p.112, grifos nossos). Então, se esta não envolve o recalque, poderia ser, paradoxalmente, dependente dele para acontecer? De acordo com Baas (2001):

A lógica desta relação entre sublimação e recalque torna-se muito sutil e bastante enigmática, pois, compreende-se bem, a pulsão sexual é sublimada, mas o caráter sexual é recalcado. Que é portanto a pulsão sexual depurada de toda a sexualidade? (2001, p.117)

O autor mostra como é difícil a tarefa de descrever o mecanismo sublimatório. A pulsão sexual é sublimada e o que nela havia de caráter sexual será recalcado. Embora o conceito de pulsão de morte só apareça em 1920, poderíamos dizer que a pulsão depurada de toda a sexualidade é a pulsão de morte.

Assim, a lógica da sublimação apresenta-se como um curto-circuito do recalque, e, portanto, da rede associativa e simbólica que constitui a mediação habitual para a descarga pulsional. (2001, p. 118)

Veremos no segundo capítulo "A melancolia", como a formação do "agente psíquico especial" e a sublimação estão intrinsecamente relacionadas.

Retomando, Freud nos diz que a sublimação pode ser estimulada pelo ideal. A problemática mistura e indiferenciação na compreensão dos termos eu ideal e ideal do eu ao longo de sua obra nos permite questionar: quem estimularia ou exigiria a sublimação, o eu ideal ou o ideal do eu? Talvez uma sublimação estimulada pelo eu ideal esteja próxima do desenvolvimento acelerado de habilidades nas crianças que precisam amadurecer rapidamente. 
Sabemos que a tradição considera o ideal do eu o ponto referencial da sublimação, sendo ele a parte "benéfica" que acompanharia o superego. Contudo, quais seriam as consequências de uma sublimação nascida do eu que busca uma reparação, do eu idealizado ou fragmentado? Se esta questão se sustenta, poderíamos imaginar, desde aqui, que os destinos da sublimação se dividiriam entre aqueles que estariam mais próximos da fonte pulsional e aqueles que estariam mais distante desse centro, e do risco de transbordamento pulsional.

Em um trecho do último poema de "A teus pés" (1982/1992), que se intitula "O fogo do final", o eu lírico busca explicações e motivos que poderiam justificar algo que não chega a ser dito, que aparece apenas como negativo, mas produz vertigem:

\footnotetext{
Vertigem das alturas.

Você está errado: não é o romance da longa vida que começa. Não foi nossa razão que deu com os burros n'água. Nem o frio na espinha dentro do ar engarrafado no aterro do Flamengo. Rush. Não foi a pressa. O estabanamento na escada em espiral. O livro que falta na estante e no entanto deveria ficar lá onde está. A amizade recente com o carteiro do Brasil, que entra vila adentro e bate na janela e me entrega o envelope pelo nome. Os grunhidos do ciúme. Minhas escapadas pelo grande mundo, suas retiradas para dentro da sólida mansão. Não foi nada disso. Então o quê? (CÉSAR,1992.p.52-53)
}

A obra de Ana C. será ilustrativa da problemática que queremos investigar e retomaremos os pontos aqui levantados no quinto capítulo.

A pulsão pode ser descrita como aquilo que dá início a um movimento e uma quantidade de trabalho. Encontramos em Freud a distinção de dois termos bem próximos para dizer de uma excitação que precisa ser contida: Reiz - para o externo, estimulação - e Erregung para o interno, excitação. De qualquer modo, Laplanche (1989) lembra que a pulsão se origina de uma excitação interna, numa força constante da qual o aparelho não consegue fugir. Desse modo, ela deve estar na origem das elaborações, "elaborações estas, que colocam em funcionamento um certo número de dispositivos que resultam em descarga pulsional e outras que incidem sobre a própria pulsão: os destinos pulsionais”. (LAPLANCHE, 1989, p.14) 
Em “Os instintos e suas vicissitudes” (1915) entendemos a sublimação como um dos destinos da pulsão, que envolve um processo de dessexualização visando um alvo não sexual. Outros possíveis destinos da pulsão são: a reversão ao seu oposto, o retorno em direção ao próprio eu do indivíduo e a repressão.

Freud nos mostra que a pulsão (Trieb) deve ser analisada em alguns aspectos: a meta, o objeto, a fonte e o impulso. Ali ele retoma a definição de 1905 que diz que a pulsão é "o representante psíquico das excitações que se originam no interior do corpo" (FREUD, 1915, p.142).

A meta imediata da pulsão é evidentemente a satisfação, ou seja, redução da tensão provocada no início pela excitação. A sublimação supõe uma mudança da meta através de uma espécie de etapa intermediária entre a satisfação libidinal direta e a satisfação que será inibida em seus objetivos.

O objeto é aquilo em que e por meio do que a pulsão pode atingir sua meta. O objeto é o que há de mais variável, a "contingência do objeto" é um aspecto que Freudressaltava: a escolha objetal não é dada a partir de uma determinação biológica. Ela conta com aspectos da história do sujeito que podem fazer com que a pulsão se fixe ou não. Assim, a articulação entre meta e objeto está no centro do problema da sublimação. Onde antes parecia haver, portanto, apenas uma mudança das metas, a dessexualização, vemos que a sublimação é um processo global que envolve, ao mesmo tempo, a meta e o objeto.

A fonte se refere ao processo somático que se localiza num órgão ou numa parte do corpo e cuja excitação é representada, na vida psíquica, pela pulsão. Freud diz que toda exigência de trabalho para a vida psíquica tem sua origem no corpo e nas zonas erógenas. As fontes podem ser diretas e indiretas - sendo que "qualquer processo somático, qualquer modificação difusa, qualquer ação, ainda que psíquica, pode, num segundo tempo, tornar-se 'fonte' da pulsão sexual”,23 (LAPLANCHE,1989, p.17). Sobre o impulso (Drang), dizemos que ele é quase a própria pulsão (Trieb) - aquilo que impele a uma ação, aquilo que introduz uma urgência talvez irreprimível. O impulso é definido como "o fator motor da pulsão, a quantidade de força ou a medida de exigência de trabalho que ela representa”. (FREUD, 1915, p.142) Nesse artigo metapsicológico,

\footnotetext{
${ }^{23}$ A escrita poderia ser aquilo que, em um segundo momento se transformaria em uma fonte indireta da pulsão? Teriamos assim um novo fluxo, uma excitação da libido que pode ser recompositora da quota narcísica, aumentar a quantidade de pulsão de vida no aparelho psíquico. Mas assim, também pode ser fator de transbordamento libidinal- uma vez reativado pelo processo da escrita.
} 
Freud ainda desenvolve seus argumentos a partir das relações prazer-desprazer que ditam o princípio do prazer que rege a primeira teoria pulsional.

\subsection{Notas sobre o risco de uma desfusão pulsional}

Estaria eu à beira de me acometer no infinito?

$$
\text { Ana } C^{24}
$$

Foi através da clínica, da observação de fenômenos como a compulsão à repetição, masoquismo e a reação terapêutica negativa que Freud questionou o princípio de prazer que regia o primeiro dualismo pulsional. A descoberta trazida em "Além do princípio do prazer" (1920) nos diz que qualquer excitação, ou exigência de trabalho dentro do aparelho psíquico pode ser percebida como desprazer, ou seja, a tendência à qual esse sistema visa é aquela que aniquila as tensões produzidas no seu interior. A partir da segunda teoria pulsional proposta em 1920 estamos sob a égide do Princípio do Nirvana, que busca a ausência de qualquer excitação dentro do aparelho psíquico. $\mathrm{O}$ surgimento da vida seria a causa de sua continuação e, ao mesmo tempo, do esforço no sentido da morte. Partimos do pressuposto de que pulsão de vida e pulsão de morte estão sempre interligadas, ou melhor, estão fusionadas, intrincadas.

Com a compreensão adquirida no estudo do narcisismo, do luto e da melancolia, Freud procura solucionar, com a segunda teoria das pulsões, a enigmática dessexualização que envolve o processo sublimatório. A libido dessexualizada retorna ao eu, que será agora objeto de investimento, para que, posteriormente, a libido possa novamente investir em outros objetos, compartilhados socialmente. Segundo Kupermann (2010, p.202):

A sublimação é descrita como um processo no qual, em um primeiro tempo, o sujeito experimenta um desligamento dos objetos que, até então, mereceram o investimento da sua "libido do objeto" (ou "sexual), o que implica, portanto, uma dessexualização, a libido sexual desligada voltando-se ao ego, tornando-se "libido do ego" ou

${ }^{24}$ (CÉSAR, 2008, p.344) 
"narcísica". Mas essa introversão da libido é, também - por meio de um mecanismo muito pouco elucidado que só pode ser nomeado de trabalho de luto -, a condição para que o sujeito crie novos objetos de investimento que venham a adquirir valor social, metamorfoseando a libido do ego mais uma vez em libido sexual, ou seja, promovendo uma sexualização.

O processo de desinvestimento dos objetos, designado como "trabalho do luto", é reconhecido no interior do mecanismo de constituição do eu e no sublimatório, bem como na melancolia. Porém, enquanto a sublimação também aponta para a possibilidade de uma mudança do objeto e do alvo da pulsão, a melancolia demonstra a incapacidade de realizar com sucesso o trabalho do luto, não sendo possível se desligar do objeto de amor no qual investia. $\mathrm{O}$ resultado dessa impossibilidade é a internalização do objeto através de uma identificação narcísica.

Para Freud (1923), o eu em constituição passaria por algo parecido com o que encontramos na melancolia. Em o "Ego e o Id" (1923), o eu é formado através desse processo no qual a libido teve que se desligar de um objeto ao qual se encontrava identificado e retornar ao eu. A retirada dessa energia que antes era destinada ao objeto implica um represamento de energia no eu. O período de narcisismo é descrito deste modo; a libido do objeto é transformada em libido do eu, sendo que esse eu será investido como se fosse um objeto $^{25}$. De acordo com Freud, o processo de desinvestimento da libido, isto é, a dessexualização necessária ao trabalho do luto para que haja o desligamento da libido ao objeto, não acontece sem riscos ao aparelho psíquico. Nesse momento, haveria a ameaça de uma desfusão pulsional, que libertaria as pulsões destrutivas dentro do aparelho psíquico e colocaria em perigo o eu.

Uma vez que a sublimação promove o desligamento dos nossos objetos de investimento, como entender a desfusão pulsional contida nesse mecanismo e sua participação na constituição do eu, onde é preciso se desligar do objeto de amor? Encontraríamos uma implicação da sublimação na constituição do eu melancólico? Seria a sublimação a responsável pela construção de um discurso melancólico?

\footnotetext{
${ }^{25}$ Como iremos desenvolver no item "O narcisismo", Freud (1914) nos indica que é necessária uma "nova ação psíquica" para que o eu possa se estruturar: "Posso ressaltar que estamos destinados a supor que uma unidade comparável ao eu não pode existir no indivíduo desde o começo; o eu tem de ser desenvolvido. Os instintos auto-eróticos, contudo, ali se encontram desde o início, sendo necessário que algo seja adicionado ao autoerotismo - uma nova ação psíquica - a fim de provocar o narcisismo." (FREUD, 1914, p.92) Vemos com Lacan que a constituição do eu se daria através da imagem do corpo que chega através do Outro; esta imagem permitiria a unificação do corpo fragmentado do momento auto-erótico. Tal leitura sugere uma correspondência entre a "nova ação psíquica" e o "estádio do espelho", formulado por Lacan em "O estádio do espelho como formador da função do eu" (1949).
} 
As duas classes de pulsões, de vida e de morte ${ }^{26}$, são igualmente conservadoras. Freud (1923) traz um argumento que nos parece ser central para nossa investigação:

A transformação da libido do objeto em libido narcísica que assim se efetua, obviamente implica numa dessexualização - uma espécie de sublimação, portanto (...) teremos de considerar se outras vicissitudes instintuais $^{27}$ não podem resultar também dessa transformação; se, por exemplo, ela não pode ocasionar uma desfusão dos diversos instintos que se acham fundidos. (FREUD, 1923, p.44-45)

A clínica da melancolia nos aparece como um lugar privilegiado de investigação do processo sublimatório e dos possíveis destinos da desfusão pulsional. Ela também nos oferece um campo de observação do funcionamento das instâncias ideais, fundamentais para a compreensão da constituição do sujeito, dos seus modos de distribuição da libido e do próprio mecanismo sublimatório. Segundo Mijolla-Mellor (2010):

\begin{abstract}
A sublimação está, na verdade, ligada ao investimento de um tempo futuro e ao trabalho para se conseguir isso. Essa é a razão pela qual se pode legitimamente aproximar a sublimação destes momentos de reelaboração identificatória que constituem o trabalho de luto, o do humor, o tempo do período de latência, bem como o da cura psicanalítica. De fato, se o ideal de eu está conforme o objetivo original (segundo Freud, tornar-se como o pai), é com qualquer espécie de atividade relacionada a esse fim que ele incita o eu, na medida em que essa atividade é suscetível de resgatar uma imagem identificatória valorizada para o eu. Assim sendo, a idealização vai introjetar identificações inconscientes emprestadas dos objetos do Édipo sem que ele tenha tido a menor elaboração do tipo sublimatório, enquanto a sublimação trabalha sobre o luto do próprio eu, mais precisamente, sobre o luto do eu-ideal todo poderoso. (MIJOLLAMELLOR, 2010, p.503)
\end{abstract}

Com efeito, deveríamos pensar em diferentes tipos de sublimação a partir do momento em que são diversas as formas de arranjos da constituição subjetiva. Teremos que considerar também que as consequências da sublimação serão diferentes para cada

${ }^{26}$ Procuraremos considerar a complexidade trazida pelo novo dualismo pulsional de 1920 , como analisa Figueiredo (1999). O autor nos demonstra como a pulsão de morte, Tanatos, corre o risco de se tornar uma noção generalista, e até mesmo imprecisa, quando entendida simplesmente como destrutividade e ódio, numa lógica dualista. Da mesma forma entenderemos Eros: "Se Eros procura ligações, há formas de Eros que produzem desligamentos e os dois movimentos podem ser absolutamente simultâneos". (1999, p.33)

${ }^{27}$ Nossa edição das Obras Completas de Freud permite um equívoco de tradução nesse momento. Onde se lê instinto, deveria-se ler pulsão. Lembramos também que os termos fusão e desfusão pulsional também são traduzidos por intrincação e desintrincação. 
sujeito. Mas quais seriam os elementos que nos permitiriam mapear os possíveis destinos da desfusão pulsional decorrente do processo sublimatório?

Desconfiamos que a desfusão pulsional empreendida pela sublimação poderia levar ao recrudescimento da força do superego reconhecidamente tirânico na melancolia. Como nos mostra Kupermann (2010, p. 202),

Porém é sabido que o circuito da sublimação, uma vez interrompido, pode comportar outras vicissitudes. A libido dessexualizada sofre uma arriscada desfusão pulsional, promovendo a presença, no eu, da pulsão de morte desligada, que será utilizada para o movimento, necessariamente agressivo, de constituição de novos objetos de investimento sexual. No entanto, se a criação se mostra inviável, em função da impossibilidade de realização do trabalho de luto - devido à eleição, pelo sujeito traumatizado, da idealização do objeto perdido -, a pulsão de morte, ao invés de contribuir para o movimento de desterritorialização necessário aos processos sublimatórios, alimenta o superego, incrementando sua fúria sádica e mortífera. "Já que o trabalho de sublimação do ego resulta numa desfusão dos instintos e numa liberação dos instintos agressivos no superego", escreve Freud, "sua luta contra a libido expõe-no ao perigo de maus-tratos e morte" (Freud, [1923] 1980: 73-74). É apenas nesse sentido que a chamada dessexualização própria ao processo sublimatório transforma-se em narcisismo de morte, característico da melancolia.

Assim, vemos que a dessexualização necessária à sublimação pode transformar-se em narcisismo de morte, como na melancolia. Mas poderemos dizer que a sublimação produz uma melancolização no sujeito ou seria necessário, antes, uma pré-disposição em sua constituição subjetiva para determinar quais seriam os destinos da sublimação?

Nossa hipótese é a de que a sublimação que cria e transforma irá retomar a maneira pela qual se deu a constituição do eu psíquico, suas primeiras relações de objeto e as marcas que essas primeiras experiências imprimiram no eu. Buscarmos entender ao longo deste trabalho, o que se passa nesse processo.

[...] além do fato de que somente se abra a sujeitos capazes de escrever, a via da escritura se revela perigosa. Se pode morrer porque algumas coisas nunca tenham sido ditas. Mas também pode-se morrer porque tenham sido ditas, porque tenham sido "mal" ditas., ou "mal escutadas, ou "mal" recebidas. . Assim, haveriam maneira boas e maneira más de dizer, bons e maus interlocutores, escrituras salvadoras e escrituras fatais. Acreditando ajustar o destino do horror, certos textos não fazem mais que precipitar nele a seus autores. Alguns textos mas não todos. Enquanto as "sublimações" fiquem à distância do trauma, parecem ter uma função vital. Permitem "tolerar o intolerável", "pensar para não morrer". Permitem ao escritor suportar. Mas a escritura de si pode também 
acercar-se das queimaduras da infância, desembocar sobre uma exposição pública do ódio sentido por outras vítimas, reavivar a vergonha e a culpabilidade. O que se passa então?(ROSENBLUM, 2002, p.148)

No próximo capítulo, "A melancolia", passaremos, inicialmente, pelos caminhos trilhados nos primeiros momentos de formação do eu, para então, entender a especificidade de uma subjetividade melancólica. 


\section{Cap. II A Melancolia}

\section{Uma arte}

A arte de perder não tarda aprender; tantas coisas parecem feitas com o molde da perda que o perdê-las não traz desastre.

Perca algo a cada dia. Aceita o susto de perder chaves, e a hora passada embalde. $A$ arte de perder não tarda aprender.

Pratica perder mais rápido mil coisas mais: lugares, nomes, onde pensaste de férias ir. Nenhuma perda trará desastre.

Perdi o relógio de minha mãe. A última, ou a penúltima, de minhas casas queridas foi-se. Não tarda aprender, a arte de perder.

Perdi duas cidades, eram deliciosas. E, pior, alguns reinos que tive, dois rios, um continente. Sinto sua falta, nenhum desastre.

- Mesmo perder-te a ti (a voz que ria, um ente amado), mentir não posso. É evidente:

$a$ arte de perder muito não tarda aprender, embora a perda - escreva tudo! - lembre desastre.

Elizabeth Bishop ${ }^{28}$

Este capítulo será dedicado à metapsicologia relacionada aos termos que compõem a problemática melancólica. Retomaremos a obra de Ana C. no quinto capítulo, após termos trazido à tona elementos que nos permitirão pensar sobre a especificidade do processo sublimatório - a escrita - para esta poeta.

\section{1 À guisa de uma introdução à melancolia: narcisismo, instâncias ideais,} desfusão pulsional

28 Tradução de Horácio Costa. 
A partir da introdução do conceito de narcisismo na obra de Freud, foi possível pensar em uma outra dinâmica na distribuição econômica da libido, a qual coloca em movimento o aparelho psíquico. No primeiro dualismo pulsional temos, de um lado, as pulsões sexuais e, do outro, o instinto de auto-conservação. $\mathrm{O}$ ego, neste primeiro momento, é considerado uma instância deslibidinizada, responsável pelo recalque das pulsões libidinais. As pulsões do ego agem de acordo com os interesses de autoconservação, ligados à preservação da espécie. As pulsões sexuais são movidas pela libido e buscam objetos que promovam satisfação, desvinculados da ordem da necessidade.

O narcisismo aparece, inicialmente, relacionado à homossexualidade masculina. A homossexualidade, como Freud apontou em "Leonardo da Vinci" (1910), seria um tipo de escolha narcísica de objeto que ocorreu devido à impossibilidade de aceitar a perda do vínculo libidinal com a mãe. Diante dessa ameaça, "o menino reprime seu amor pela mãe; coloca-se em seu lugar, identificando-se com ela, e toma a si próprio como um modelo a que devem assemelhar-se os novos objetos de seu amor" (FREUD, 1910, p.92).

Já em "Totem e tabu" (1913), o narcisismo aparece como uma estrutura permanente na história libidinal do sujeito e não somente como uma fase evolutiva passageira. $\mathrm{O}$ narcisismo faria parte da estruturação do ego, instância essa capaz de unir as pulsões dispersas do momento auto-erótico anterior. A estruturação do ego se daria através de uma relação com as figuras parentais que, ao investir libidinalmente no corpo do bebê, transformam o auto-erotismo originário em um narcisismo primário. Esse narcisismo primário nos conta que o investimento no eu ocorre antes que seja possível um investimento em um objeto externo, seja por transbordamento da libido que foi concentrada no eu, ou por uma necessidade de expansão que seria da ordem de uma ousadia do sujeito, uma expansão criativa (KUPERMANN, 2003). A libido, parte então, do eu em direção a um objeto externo, sendo que este eu, ainda indiferenciado de seu ambiente, experimenta com essa escolha de objeto, uma satisfação libidinal que é imperativa do Id - instância psíquica de onde partem as pulsões. Quando não é mais possível o investimento libidinal no objeto externo, a libido retorna ao ego. Com Freud nos lembramos de que a libido nunca quer abrir mão de nenhuma satisfação. A pulsão que é destinada a encontrar satisfação toma agora o eu como objeto de investimento, mas para tanto, é necessário um trabalho de dessexualização dessa libido que estava investida no objeto externo para que ela possa retornar ao eu. Agora o ego também é 
objeto de investimento libidinal e não somente a força recalcante. Freud (1914) postula então, um novo conflito psíquico: a libido do objeto é contraposta a uma libido do ego. Contudo, essa formulação se torna problemática, uma vez que o conflito não obedece ao sistema anterior no qual as pulsões tinham naturezas diferentes. É em "Sobre narcisismo: uma introdução" (1914) que tal conceito é apresentado e justificado através da análise das seguintes fontes: as psicoses, a vida mental das crianças, a vida mental dos povos primitivos, a distribuição da libido no adoecimento orgânico, a hipocondria e a observação da vida erótica dos sexos.

Freud ao analisar as neuroses de transferência - histeria, neurose obsessiva observa que há um investimento de libido em objetos externos e uma ligação com a realidade que de modo algum é cortada totalmente. Um paciente que sofre de histeria ou neurose obsessiva tem a relação com as pessoas e as coisas do mundo externo retidas na fantasia, ou tem seus objetos da memória substituídos por objetos reais. Ele pode também misturar esses dois e ainda renunciar "[...] à iniciação das atividades motoras para a obtenção de seus objetivos relacionados àqueles objetos” (FREUD, 1914,p.90). Nas parafrenias, categoria que incluía as esquizofrenias e as paranóias, parecia haver uma retração da libido para o mundo interno sem que houvesse uma substituição do mundo externo na fantasia: "Quando realmente as substitui, o processo parece ser secundário e constituir parte de uma tentativa de recuperação, destinada a conduzir a libido de volta a objetos" (FREUD, 1914, p.91). A libido que se afastou do mundo externo é dirigida de volta ao ego: esse retorno chamamos de narcisismo secundário. A megalomania, que é característica dos estados esquizofrênicos, irá apontar para um afastamento da libido do mundo externo que ficará retida no ego. Freud nos diz que ela não é uma criação nova, mas uma ampliação e amostra mais clara de uma condição existente anteriormente. Segundo ele: "Isso nos leva a considerar o narcisismo que surge através da indução de catexias objetais, como sendo secundário, superposto a um narcisismo primário que é obscurecido por influências diferentes"(FREUD, 1914, p.91). Haveria um primeiro momento, quando o corpo do bebê é investido auto- eroticamente, e um segundo momento de investimento em objetos externos. Contudo, "somente quando há catexia objetal é que é possível discriminar uma energia sexual - a libido de uma energia dos instintos do ego" (FREUD, 1914, p.92) Assim, Birman (2006, p.127) afirma:

entre desamparo e onipotência oscila a subjetividade humana de acordo com a leitura freudiana do eu e do narcisismo, indicando ao 
mesmo tempo a fragilidade daquela e a sua pretensão divinizante. (...) $\mathrm{O}$ eu seria então a construção sólida pela qual o sujeito procura proteger-se do descentramento radical em todas as suas dimensões, isto é, o inconsciente, o desejo, a pulsão, o outro.

Na vida mental das crianças e dos povos primitivos, encontramos traços isolados do que seria uma megalomania: a "onipotência de pensamentos" - o que confere poder de realidade aos desejos e atos mentais - e a confiança no poder mágico das palavras, crença que serve como princípio lógico de explicação do mundo externo. Freud nos mostra que há uma antítese entre a libido do ego e a objetal: quanto mais uma é utilizada, mais a outra se esvazia.

No adoecimento orgânico, a libido e o interesse do ego partilham o mesmo destino, os investimentos libidinais são retirados de volta para o ego do enfermo e colocados para fora quando ele se recupera. Enquanto está adoecido, os investimentos libidinais aos objetos amorosos e ao mundo externo são retirados, concentrando-se no órgão que sofre. Na hipocondria, por exemplo, acontece um processo mórbido de afastamento da libido de seus objetivos, uma vez que o órgão doente não apresenta mudanças observáveis organicamente.

Sobre a vida erótica dos seres humanos, Freud (2014) nos diz:

\begin{abstract}
Assim como a libido objetal inicialmente ocultava de nossa observação a libido do ego, também em relação à escolha de objeto nas crianças de tenra idade (e nas crianças em crescimento) o que primeiro notamos foi que elas derivavam seus objetos sexuais de suas primeiras experiências de satisfação.(FREUD, 1914, p.103)
\end{abstract}

O ser humano teria, originalmente, dois objetos sexuais, ele próprio e a mulher que dele cuida. Assim, ele postula que "a existência de um narcisismo primário em todos, o qual, em alguns casos, pode manifestar-se de forma dominante" (FREUD, 1914, p.105). Os objetos de amor serão escolhidos de acordo com o tipo narcisista ou o tipo anaclítico. No tipo narcisista, escolha objetal privilegiada na melancolia, a pessoa amará o que ela própria é, o que ela foi, o que gostaria de ser, ou alguém que foi uma vez parte dela mesma. No tipo anaclítico a pessoa pode amar a mulher que a alimenta, o homem que a protege, bem como os substitutos dessa função que tomarão seu lugar (FREUD, 1914, p.107). O narcisismo primário infantil será refreado em detrimento das aquisições culturais que impõem uma renúncia ao prazer e aos privilégios concedidos à criança. A repressão, antes exercida pelo ego, será desempenhada pelo amor-próprio do ego, noção 
essa que incluiria o investimento libidinal no ego. O narcisismo nos leva a questionar as origens da formação do eu e sobre as condições dadas para os seus primeiros investimentos objetais, isto é, de onde foi que eles partiram, uma vez que é preciso que exista um eu sujeito da ação. Freud (1914) diz:

Posso ressaltar que estamos destinados a supor que uma unidade comparável ao ego não pode existir no indivíduo desde o começo; o ego tem de ser desenvolvido. Os instintos auto-eróticos, contudo, ali se encontram desde o início, sendo necessário que algo seja adicionado ao auto-erotismo - uma nova ação psíquica - a fim de provocar o narcisismo. (FREUD,1914,p.92)

O eu, segundo Garcia-Roza (1996, p.150), "antes de ser um agente de ligação ele é um efeito dela. Não há eu anterior à ligação". Já Ribeiro (2000) irá nos dizer que essa ação específica é criadora, ao mesmo tempo, do narcisismo e do eu. O autor irá situar a ação específica na identificação feminina primária, que se refere à identificação precoce com a mãe $e^{29}$.

Reconhecemos o aparelho psíquico como um dispositivo que tem o objetivo de dominar as excitações, as quais podem ocasionar desprazer ou desenvolver patologias. Para tanto, a elaboração psíquica ${ }^{30}$ auxilia no escoamento das excitações e a nova ação psíquica mencionada deve estar relacionada a essa tentativa. Os impulsos libidinais terão o destino da repressão se entrarem em conflito com as ideias éticas e culturais do indivíduo. Tal repressão ainda não terá um caráter intelectual: ela provém do ego, ou do amor próprio deste, reconhece em si os padrões de exigência aos quais deverá se submeter. Isto é, o ego fixa para si um ideal pelo qual mede seu ego real. A formação de um ideal se torna um fator que condiciona a repressão. O que é projetado como sendo ego ideal é o "substituto do narcisismo perdido de sua infância na qual ele era o próprio ideal" (FREUD, 1914, p.111).

\footnotetext{
29 "Essa "nova ação psíquica" que é a identificação primária, na medida em que é incapaz de cobrir a totalidade do que foi vivenciado sob a forma auto-erótica, acarreta obrigatoriamente a formação de um resto constitutivo de um primeiro núcleo inconsciente e, consequentemente, inaugura a primeira oposição entre o recalcado e as forças recalcantes. Esses primeiros momentos de formação do eu se confundem, então, com um narcisismo totalmente impregnado de feminilidade, o que nos leva a pensar que não é tanto a mulher que é narcísica por excelência, como queria Freud, mas que o narcisismo é, originariamente, feminino por excelência” (RIBEIRO, 2000, pp. 47-48).

${ }^{30}$ Ao contrário de Laplanche, preferimos o termo "elaboração psíquica" ao termo perlaboração. "A expressão elaboração é utilizada por Freud para designar, em diversos contextos, o trabalho realizado pelo aparelho psíquico com o fim de dominar as excitações que chegam até ele e cuja acumulação ameaça ser patogênica. Este trabalho consiste em integrar as excitações no psiquismo e em estabelecer, entre elas, conexões associativas. (LAPLANCHE, PONTALIS, 1988, p.196)
} 
Assim, vemos como as instâncias ideais desempenham um papel fundamental na dinâmica psíquica, sendo, particularmente importantes para iluminar o complexo melancólico e o processo sublimatório. A seguir, buscaremos obter uma melhor compreensão interna, também, sobre as dimensões tópicas e econômica destas.

\section{O eu e as instâncias ideais}

As instâncias ideais são testemunhas do papel que o outro adulto desempenha na constituição subjetiva. A alteridade é compreendida como algo que antecede o sujeito e o traumatiza, no entanto, esse é exatamente o processo que o constituirá. A chamada "condição antropológica universal" do humano - o desamparo e dependência do bebê ao outro cuidador - implica uma passividade radical frente ao outro. $\mathrm{O}$ outro precede o sujeito, o constitui, o traumatiza e exige dele trabalho -que podemos entender como exigência de trabalho psíquico de simbolização, elaboração e transformação daquilo que vem desse outro e excede ao sujeito. Há uma dimensão da constituição subjetiva que encontra uma "abertura permanente e inevitável ao outro, em sua alteridade que sempre ultrapassará, por princípio, a nossa possibilidade de recepção, acolhimento e compreensão e que, no entanto, como expressão do sofrimento, nos exige alguma resposta" (COELHO JUNIOR e FIGUEIREDO, 2012. p. 32). Essa relação com a alteridade, a qual implica constantes traumatismos, pode ser considerada mais tributária das pulsões de morte, do excesso que não é simbolizado, promovendo rupturas e desligamentos. Contudo, sabemos que esse último é também responsável por colocar em marcha o psiquismo, evitando o enrijecimento das ligações e o narcisismo mortífero, como nos propõe Green (1988).

A exigência de representação trazida pela pulsão traz junto de si o protótipo das

relações objetais de um sujeito. É diante da condição imposta ao pequeno sujeito, o qual, ao nascer, está em total dependência do cuidador adulto - que pensamos o surgimento das relações objetais e das representações. $\mathrm{O}$ bebê carece de recursos que o possibilitem dominar as excitações criadas tanto pelo corpo, através das exigências vitais como a fome e a sede, mas também das contingências ambientais como o frio, calor, luz, sons, enfim, vários estímulos que precisam ser identificados para que possam ser manejados e dominados pelo sujeito. A representação de um eu com contornos e 
limites que diferenciem o que é o externo, o não-eu, e o interno, se dá aos poucos. O surgimento do eu depende da relação do sujeito com o outro que dele cuida, seu primeiro objeto de investimento amoroso. Esse papel de cuidador é, na maioria das vezes, realizado pela mãe. A condição de desamparo da criança ao nascer requer da mãe inferências sobre as necessidades do filho. O leite e o seio oferecidos apaziguam, num primeiro momento, o corpo que se debate com o excesso de estímulos que lhe chegam de uma só vez. Freud (1895, p.336-337) nos diz como a primeira mamada seria a primeira experiência de satisfação do bebê. O bebê tentará reencontrar esse mesmo alívio sentido com a contenção física de seu corpo, a oferta de alimento e calor numa próxima vez que sentir fome. Essa experiência tem a intensidade de produzir um traço mnêmico no prematuro aparelho psíquico, que será retomado, como uma tentativa de alucinar o objeto que ofereceu conforto e satisfação das exigências corporais. Talvez não fosse descabido pensar que esse esforço psíquico de representação de um estímulo para que a pulsão possa aí procurar se satisfazer pode ser considerado como a primeira forma de sublimação da pulsão dentro do aparelho psíquico.

O ego prematuro começa a buscar ligações entre as experiências percebidas e formar representações delas. Para que seja possível se organizar internamente é necessário encontrar objetos aos quais a pulsão possa se ligar. A satisfação pulsional decorre da possibilidade de aliviar o excesso desgovernado de tensão produzido pelas fontes pulsionais e pelo exterior, desse modo, o eu que se forma poderá prever e controlar os estímulos externos. Esta fase do desenvolvimento psíquico é conhecida como fase oral, e a apreensão do mundo pelo bebê é dada por mecanismos de introjeção e projeção. Freud diz (1923, p.43): “A princípio, na fase oral primitiva do indivíduo, a catexia do objeto e a identificação são, sem dúvida, indistinguíveis uma da outra (...)”. O canibalismo, por exemplo, seria, a um só tempo, amor e destruição do objeto. Através do protótipo da relação oral o objeto é ingerido, sendo que os modos como esta primeira identificação se dá poderão influenciar as identificações secundárias ${ }^{31}$. Os investimentos aos objetos surgem do id. O ego, posteriormente, irá se sujeitar a esses desejos ou tentará reprimi-los. O id percebe as tendências eróticas como necessidades, isto é, não se trata de um instinto natural que irá encontrar um objeto certo para se satisfazer. A ordem da necessidade será contaminada pelo investimento psíquico realizado pela entrada do outro nos primórdios da vida. Com efeito, o investimento em objetos

\footnotetext{
${ }^{31}$ Como veremos a seguir, a introjeção deve ser diferenciada da incorporação, ambas resultando em uma identificação.
} 
externos nesse primeiro momento é considerado uma identificação. Ela aparece como uma tentativa de apreensão do objeto para satisfazer o id. Será a interferência da realidade (que demonstra que o objeto de escolha amorosa não está disponível sempre que o sujeito o reivindicar) que irá fazer com que o ego busque formas de domesticar e introjetar o objeto. A identificação, ou seja, ter dentro de si o que antes era externo e muitas vezes frustrante, é uma forma de manutenção do objeto de amor. Freud (1923, p.43) nos diz que "pode ser que essa identificação seja a única condição em que o id pode abandonar os seus objetos". Seguimos nosso raciocínio com Freud (1923, p.44):

[...] pode-se dizer que essa transformação de uma escolha objetal erótica numa alteração do ego constitui também num método pelo qual o ego pode obter controle sobre o id e aprofundar suas relações com ele - à custa, é verdade, de sujeitar-se em grande parte às exigências do id. Quando o ego assume as características do objeto, ele está-se forçando, por assim dizer, ao id como um objeto de amor e tentando compensar a perda do id, dizendo: Olhe, você também pode me amar; sou semelhante ao objeto.

É interessante acompanharmos que quando uma pessoa precisa abandonar um objeto sexual, "muito amiúde se segue uma alteração de seu ego que só pode ser descrita como instalação do objeto dentro do ego, tal como ocorre na melancolia." (FREUD, 1923, p.43, grifos nossos) Esse processo de identificação que ocorre nas fases iniciais de desenvolvimento "torna possível supor que o caráter do ego é um precipitado de catexias objetais abandonadas e que ele contém a história dessas escolhas de objeto" (FREUD, 1923.p.43). O ego é formado através desse processo no qual a libido teve que se desligar de um objeto ao qual se encontrava identificado e retornar ao eu. $\mathrm{O}$ retorno ao eu dessa energia, que antes era destinada ao objeto, implica um represamento de energia no eu. O período de narcisismo, como vimos, é descrito deste modo: a libido do objeto é transformada em libido do eu, sendo que esse ego será investido como se fosse um objeto ${ }^{32}$.

França Neto (2005) nos mostra como o psiquismo surge a partir de paradoxos: a identificação é, ao mesmo tempo, representação (interno) e objeto (externo). Ou seja,

o eu instaurado e constituído por identificações é ao mesmo tempo interno (ele é uma diferenciação do isso, sendo então constituído por representações catexizadas) e externo (visto e tratado como um objeto propriamente dito). Ou seja, na identificação, ou no ponto de identificação, iguala-se interno e externo, o que é outra situação paradoxal. (FRANÇA NETO, 2005, p. 97)

\footnotetext{
${ }^{32}$ Empregamos os termos "ego" e "eu" sem nenhuma diferença a ser privilegiada.
} 
Veremos que o supereu também mantém essa ambígua posição, ele faz parte do eu e tem uma existência separada dele. $\mathrm{O}$ eu é sujeito e objeto, uma parte diferenciada do id que, também é vista por esse como objeto. $\mathrm{O}$ eu precisa que o ambiente (geralmente a mãe) lhe permita acreditar que o objeto de que ele necessita para aliviar seu desconforto e atender à sua necessidade (como o leite) poderá ser achado-encontrado sempre que dele se necessitar, como nos mostra Winnicott (1975). A crença mágica de que se opera com todo o poder no mundo deve ser, a princípio, reforçada para que, posteriormente, o pequeno sujeito seja confrontado não com sua onipotência, mas com sua limitação, incompletude, insuficiência e castração. O princípio de realidade e a interdição de um terceiro irão impossibilitar que o pequeno sujeito mantenha o mesmo tipo de relação que desfrutava com o objeto, período onde espera-se que haja um acolhimento do ambiente e onde ainda não está clara a separação entre a díade mãe-bebê. É essa separação dolorosa que irá precipitar a formação do que chamamos de "eu-ideal": o bebê buscará uma referência que indique quem ele era antes da separação ou o quê teria garantido a relação anterior. Aquele que antes acreditava ser o único objeto de investimento materno irá dar-se conta de que além dele, existem muitos outros, com necessidades, interesses e desejos diferentes. $O$ pequeno passa a observar o ambiente na busca de um modelo ou referencial, quando então, começa a se configurar um romance familiar, uma criação de fantasias que oferecem narrativas que expliquem o mundo e o lugar no qual se está inserido. O sujeito cria para si um ideal que será uma referência de comparação entre quem se é, o que se imagina ser e o que acredita dever ser, isto é, quais parâmetros são precisos alcançar para que seja possível obter reconhecimento e amor.

A criação do ideal do eu passa por um processo que se assemelha ao mecanismo sublimatório: o objeto externo que não pode mais ser investido - o pai com o qual se identifica - deverá ser elevado a um ideal, tendo em mente a injunção "seja como seu pai, mas até certo ponto", uma vez que o acesso à mãe pertence a ele. Esse processo de identificação ao pai também envolve uma dessexualização da pulsão antes de se ter, com o retorno da libido, a introjeção do objeto em uma instância diferente do eu - o superego e o ideal do ego. Na literatura psicanalítica, eles ora aparecem separados, ora como facetas de um mesmo destino de objeto. O pai, é simultaneamente o modelo de identificação, e aquele que limita, censura e pune o sujeito. 
O superego traz consigo as vias afetivas da ambivalência de sentimentos em direção às figuras parentais e de autoridade. O superego só será pensado como uma instância psíquica a partir de 1923, em "O ego e o id", contudo, já podemos encontrar na primeira tópica a presença de um agente censor ${ }^{33}$. Iremos localizar também em Freud a presença de um superego arcaico, apesar desta ser reconhecida majoritariamente apenas como herdeira do complexo de Édipo. Freud (1917[1915]) nos diz em “A pulsão e seus destinos":

Aqui estamos familiarizados com o agente comunitário denominado 'consciência'; vamos incluí-lo, juntamente com a censura da consciência e do teste da realidade, entre as principais instituições do ego, e poderemos provar que ela pode ficar doente por sua causa própria. ((1917[1915]), p.280, grifos nossos)

A consciência da criança desde cedo é desenvolvida a partir da relação com seus objetos de amor, suas condutas são avaliadas de forma a evitar a perda da estima dos objetos amados, como lemos a seguir:

Os tormentos causados pelas censuras da consciência correspondem precisamente ao medo da perda de amor, por parte de uma criança, medo cujo lugar foi tomado pelo agente moral. Por outro lado, se o ego resistiu com êxito à tentação de fazer algo que, para o superego, seria censurável, ele sente-se elevado em sua auto-estima e fortalecido em seu orgulho, como se houvesse feito alguma preciosa aquisição. (FREUD, 1938, p 236).

O ego precisa avaliar os objetos ou conteúdos que podem ser investidos sem a restrição de uma consciência moral. Os conteúdos que causam uma perturbação na representação de eu que foi oferecida pelo outro - e que agora o eu faz de si - caso não possam ser aceitos, encontrarão o destino da repressão. A especialização dentro do próprio ego, uma forma de auto-observação, será correlata das restrições feitas pelos

\footnotetext{
${ }^{33}$ Teremos que levar em conta a força da atividade crítica do eu desde os tempos mais iniciais e retomar algumas das considerações de Freud que já foram feitas a esse respeito, uma vez que na teorização sobre a primeira tópica psíquica não encontramos referências nítidas aos períodos do desenvolvimento em que se daria essa separação entre o eu e sua instância crítica. De acordo com Figueiredo (2012), quando o outro não puder ser introjetado de maneira a vir fazer parte do eu ele se tornará o elemento não digerível que encontraremos no "Supraeu", um superego arcaico que ainda está distante da função moralizadora e normativa, que aparece de forma aterrorizadora e disruptiva como as vozes que assediam o sujeito. De acordo com o autor "as identificações que compõem o supra-eu são justamente as funções intersubjetivas que não passaram por processos de introjeção eficazes - ou seja, foram incorporadas". A incorporação aqui é entendida no sentido de elementos que não puderam ser assimilados e permanecem como um corpo estranho interno, uma "cripta", como M. Torok e N. Abraham nos falam em “A casca e o núcleo" (1995). Insistimos junto a Figueiredo e Ferenczi que o id e o superego são mais arcaicos que o ego.
} 
pais, pelo princípio de realidade e pela cultura de um modo geral. A condição de formação do superego seria dada a partir do momento em que é exigida da criança uma renúncia aos seus objetos de amor.

A criança encontra-se dentro do romance familiar, vivenciando o complexo de Édipo que é composto por sentimentos ambivalentes de amor e ódio aos pais. Será necessário, então, encontrar uma forma ou uma resposta para os conflitos que surgem desse romance (FREUD, 1910, p.155) ${ }^{34}$. A bissexualidade pré-existente deverá dar lugar a uma identificação com uma das figuras parentais e o objeto de amor primordial se tornará um objeto de impossível realização. Assim, temos que o ideal com o qual o eu se identificava não é mais condizente com o que é percebido por ele. De certa forma, a ideia anteriormente construída para si, referente a quais atributos ou qualidades seriam necessários para que o eu se sentisse amado por seu objeto, permanecerá como um ponto impossível de ser alcançado. O que é impossível aparece como um ideal e o sentimento de plenitude e completude que o eu experimentou no seu período narcísico continua sendo buscado.

Diante desses desafios que encontramos na formação do eu, os pais vêm ao auxílio das crianças contra os perigos externos, mas exigem em troca um temor, chamado por Freud de "temor pela perda do amor". Este temor fica explícito e é decisivo no complexo de Édipo: a criança se sente ameaçada tanto no seu narcisismo quanto na sua relação com aquele que é sua ligação com a cultura. É neste contexto que Freud (1923, p.51) entende o superego como o herdeiro do complexo de Édipo, pois tanto os objetos de amor com os quais o eu se ligava, quanto o ideal que tinha de si (o amor ao eu que é investido como objeto) serão abandonados, não sem antes serem instalados no psiquismo em uma instância diferente do eu, o superego. Assim, como vimos, a função que os pais exerciam de avaliação moral, de censura, limitação, crítica e julgamento, será incluída no eu sob a forma de um ideal em relação ao qual o eu se orientará, isto é um "ideal do eu". A antiga forma de auto-representação de um eu que teria sido perfeito

\footnotetext{
${ }^{34} \mathrm{O}$ complexo de castração, aqui explicado brevemente, descreve como a criança é confrontada com questões sobre sua própria identidade sexual e suas escolhas amorosas. Tanto o menino quanto a menina buscarão dar respostas ao enigma da diferença anatômica entre os sexos. Segundo Freud, o menino, tomado pela angústia de castração, irá abrir mão do seu primeiro objeto de amor incestuoso para não sofrer a retaliação de ter seu órgão genital "amputado" - como presumiu ter acontecido com as meninas. A menina, sob a influência da inveja do pênis, sente a ausência desse órgão como um dano que ela buscará compensar, negar ou reparar. O complexo de castração está, nos dois casos, intimamente ligado ao complexo de Édipo. Enquanto no menino ele coloca fim ao complexo de Édipo, na menina, ele será seu ponto de partida.
} 
e se torna modelo de auto-comparação é considerada o "eu ideal". Segundo Freud (1923, p.54):

Se o ego não alcançou êxito em dominar adequadamente o complexo de Édipo, a catexia energética do último, originando-se do id, mais uma vez irá atuar na formação reativa do ideal do ego. A comunicação abundante entre o ideal e esses impulsos instintuais do Ics soluciona o enigma de como é que o próprio ideal pode, em grande parte, permanecer inconsciente e inacessível ao ego.

Em linhas gerais, esse é, o caminho da libido que encontramos no desenvolvimento de um psiquismo essencialmente neurótico. Contudo, entendemos que, antes da problemática edípica, existe um conjunto de circunstâncias a serem percebidas, interações que serão determinantes nos futuros modos de relação com o mundo e seus objetos. Assim, retomamos Freud (1923, p.64):

Temos afirmado repetidamente que o ego é formado, em grande parte, a partir de identificações que tomas o lugar de catexias abandonadas pelo id; que a primeira dessas identificações sempre se comporta como uma instância especial no ego e dele se mantém à parte sob a forma de um superego; enquanto que posteriormente, à medida que fica mais forte, o ego pode tornar-se mais resistente às influencias de tais identificações. O superego deve sua posição especial no ego, ou em relação ao ego, a um fator que deve ser considerado sob dois aspectos: por um lado, ele foi a primeira identificação, uma identificação que se efetuou enquanto o ego era muito fraco; por outro, é o herdeiro do complexo de Édipo e, assim, introduziu os objetos mais significativos no ego.[...] Ele (o superego) constitui uma lembrança da antiga fraqueza e dependência do ego, e o ego maduro permanece sujeito à sua dominação. Tal como a criança esteve um dia sob a compulsão de obedecer aos pais, assim o ego se submete ao imperativo categórico de seu superego.

Aqui inferimos que o superego, ou a função superegóica, já aparece nos primeiros momentos da constituição psíquica. Ele seria o efeito retroativo da pulsão de morte enviada ao mundo externo e ao mesmo tempo a primeira identificação - os restos do objeto anteriormente investido que agora são colocados dentro de si. Sublinhamos essa ideia, trazida anteriormente, de que se trataria de uma identificação que ocorre num período em que o eu ainda é frágil ${ }^{35}$. A economia paradoxal do superego mostra que ao mesmo tempo em que o superego surge como um produto ou efeito da pulsão de morte,

\footnotetext{
${ }^{35}$ Melanie Klein observa em sua clínica com crianças que a origem do superego seria muito anterior à proposta por Freud em 1923. O sentimento de culpa, norteador da percepção e introjeção do outro, seria decorrente da posição depressiva, como veremos adiante.
} 
é ele que promove a ligação dessa pulsão de agressão, de destruição, mesmo que para isso uma parte do eu seja sacrificada. O superego encontra-se numa posição intermediária entre o id e o mundo externo, reunindo em si as influências do passado e do presente. Dessa forma, a origem do superego é pulsional ${ }^{36}$, embora suas aspirações sejam as mais altas e distantes da vontade de satisfação imediata provinda do id. Nas palavras de Freud (1923, p. 54): "o combate que outrora lavrou nos estratos mais profundos da mente, e que não chegou ao fim devido à rápida sublimação e identificação, é agora continuado numa região mais alta (...)". Isto é, o ego adota os mesmos métodos de defesa contra as exigências do mundo externo e interno e ambos o ameaçam com a aniquilação, "mas a sua defesa contra o inimigo interno é particularmente inadequada" (FREUD, 1938, p 229). O ego, por ter sido igual ao id, sofre com os ataques do id que permanecem como ameaças, mesmo que tenham sido temporariamente dominados.

Freud, em "O mal-estar na civilização"(1930), nos diz que poderíamos considerar que a criança desenvolva quantidades consideráveis de agressividade contra a autoridade, geralmente pai e mãe, que irão inibir este impulso. A criança se vê obrigada a renunciar à satisfação dessa "agressividade vingativa e encontra uma saída para esta situação economicamente difícil com o auxílio de mecanismos familiares" (FREUD, 1930, p.153). É através da identificação que a criança irá resolver esta situação, ao incorporar a si a autoridade inatacável. É interessante percebermos como os papéis são distribuídos nesse momento: a autoridade se transformará no superego da criança, porém, exercerá a posse de toda a agressividade que a criança gostaria de exercer contra a própria figura de autoridade, sendo que o ego da criança adquirirá o papel da autoridade que foi assim degradada. Para Freud (1930, p.153), “o relacionamento entre o superego e o ego constitui um retorno, deformado por um desejo, dos relacionamentos reais existentes entre o ego, ainda individido, e o objeto externo". Relembramos aqui a importância das primeiras relações objetais, modelos que serão determinantes das futuras relações intersubjetivas. O ego está a todo tempo sendo fragilizado em suas forças e submetido a diversas exigências, vindas da realidade externa, do superego e do id. Freud (1938, p.230) diz que:

(...) desponta em nós a compreensão de que essa tentativa precoce de represar o instinto sexual, um partidarismo tão decidido por parte do incipiente ego em favor do mundo externo, em oposição ao mundo

\footnotetext{
${ }^{36}$ Conforme afirma Marta Rezende Cardoso. In: Superego. São Paulo: Editora Escuta, 2002.
} 
interno, ocasionado pela proibição da sexualidade infantil, não pode deixar de ter efeito na disposição posterior do indivíduo para com a cultura. As exigências instintivas forçadas a afastar-se da satisfação direta são compelidas a ingressar em novos caminhos que conduzem à satisfação substituta, e, no curso desses detours, podem tornar-se dessexualizadas e a sua vinculação com seus objetivos instintivos originais pode tornar-se frouxa.

Neste ponto, encontramos dentro do próprio mecanismo da constituição do eu os pressupostos necessários para a sublimação e elementos característicos da melancolia: a dessexualização da pulsão, o conflito com o superego e a identificação com o objeto perdido. Teremos que considerar a noção de pulsão de morte em sua radicalidade para compreender o complexo melancólico. Dessa forma, quando o ego utiliza os investimentos objetais lançados pelo id, isto é, quando a energia objetal se transforma em libido narcísica - uma vez que o eu se tornou objeto de amor do id através de uma identificação - , ele "está trabalhando em oposição aos objetivos de Eros e colocando-se a serviço de impulsos instintuais opostos" (FREUD, 1923, p. 61). Isso porque "o ego, sublimando um pouco da libido para si próprio e para seus propósitos, auxilia o id em seu trabalho de dominar as tensões" (FREUD, 1923, p.63). Essas noções serão de fundamental importância para a investigação do problema que levantamos sobre o processo de sublimação na melancolia, que será pensado através da obra de Ana Cristina César.

Freud nos indica que é na perturbação melancólica que melhor podemos obter uma compreensão a respeito desse elemento da constituição do eu humano, onde uma parte do ego se coloca contra a outra, julga-a e a toma como seu objeto: "uma perda objetal se transformou numa perda do ego, e o conflito entre o ego e a pessoa amada, numa separação entre a atividade crítica do ego e o ego enquanto alterado pela identificação". O superego atua como o representante do id que possui as forças de Eros e Tanatos lutando dentro dele. Será necessário nos aproximarmos, ainda mais, da relação entre o eu e o supereu, instâncias que reúnem movimentos - dinâmicos, tópicos e econômicos necessários para a compreensão do mecanismo da sublimação na melancolia. Freud nos que o ego retira libido do id e transforma as catexias objetais deste em estruturas do ego. De uma maneira que ainda nos é obscura, com a ajuda do superego, ele se vale das experiências de época passadas armazenadas no id:

para com as duas classes de instintos, a atitude do ego não é imparcial. Mediante seu trabalho de identificação e sublimação, ele ajuda os instintos de morte do id a obterem controle sobre a libido, mas, assim 
procedendo, corre o risco de tornar-se objeto dos instintos de morte e de ele próprio perecer. A fim de poder ajudar desta maneira, ele teve que acumular libido dentro de si; torna-se assim o representante de Eros e, doravante, quer viver e ser amado (FREUD, 1923, p.73, grifos nossos).

Estamos diante de um sério risco para o sujeito nesse momento, a "dominação das tensões”, a partir de 1920, implica não só evitar o aumento ou diminuição da tensão observando assim o Princípio de Constância dentro aparelho psíquico. Freud nos indica que qualquer excitação ou exigência de trabalho dentro deste aparelho pode ser percebida como desprazer - sendo que a tendência à qual o aparelho psíquico visa é aquela que aniquila as tensões produzidas no seu interior ${ }^{37}$. Pretendemos seguir as consequências dessa operação no aparelho psíquico e para isso trazemos um argumento de Freud que referencia nossa investigação:

A transformação da libido do objeto em libido narcísica que assim se efetua, obviamente implica numa dessexualização - uma espécie de sublimação, portanto (...) Teremos de considerar se outras vicissitudes instintuais não podem resultar também dessa transformação; se, por exemplo, ela não pode ocasionar uma desfusão dos diversos instintos que se acham fundidos. (FREUD, 1923, p.44-45, grifos nossos)

Encontramos aqui a confluência dos termos que identificamos no conjunto de nossa questão. Como vimos no capítulo "A sublimação", a desfusão pulsional é incluída em sua dinâmica em 1923, indicando destinos para a pulsão, antes insuspeitos.

Após a sublimação, o componente erótico não mais tem o poder de unir a totalidade da agressividade que com ele se achava combinada, e esta é liberada sob a forma de uma inclinação à agressão e à destruição. Essa desfusão seria a fonte do caráter geral de severidade e crueldade apresentado pelo ideal. (1923, p. 71, grifos nossos)

A problemática da desfusão pulsional que vemos aqui estará presente ao longo de todo o trabalho. Será através da noção de desfusão e refusão pulsional que tentaremos entender os mecanismos tanto da sublimação, quanto da melancolia.

${ }^{37}$ A ideia de um narcisismo de morte se impõe a nós, como indicado por André Green (1988). 


\section{A Desfusão pulsional}

A desfusão pulsional é a protagonista de nossa problemática da sublimação e da melancolia. Se acreditamos com Freud que o trabalho de sublimação implica em uma desfusão dos instintos que antes se encontravam ligados, precisamos entender o por quê isso se dá, qual é a dinâmica e a economia da fusão e desfusão pulsional no aparelho psíquico. Veremos com Lambotte (1997) e Rosenberg (2003) que a melancolia seria um derivado das pulsões de morte não suficientemente neutralizadas. Será o exemplo freudiano principis da desfusão pulsional, a saber, masoquismo moral, que irá nos mostrar como se dá, para o melancólico, a relação entre suas instâncias psíquicas e os objetos do mundo externo.

Com Freud, acompanhamos as formulações sobre a sublimação até a introdução da noção de pulsão de morte e constatamos a importante descoberta de que o trabalho de sublimação acarreta uma desfusão dos instintos que estavam ligados, colocando em risco a vida do eu. Diante desta colocação, somos levados a analisar os momentos em que se faz necessário o "trabalho de sublimação do ego", momentos em que o trabalho de dessexualização da libido pode incorrer em graves consequências para o eu. Tanto a formação do eu como o processo de identificação, o trabalho de luto e a identificação narcísica na melancolia envolvem mecanismos de dessexualização da libido que estão diretamente relacionados com a desfusão pulsional, mencionada acima. A sublimação e a melancolia compartilham então, de elementos que estão interligados e precisam ser investigados desde as origens da constituição do sujeito ${ }^{38}$. Como veremos, os elementos desfusionantes por excelência, são a sublimação, a identificação, o masoquismo, a ambivalência e o trauma.

É em "O problema econômico do masoquismo" (1924) que serão desenvolvidas as noções de fusão e desfusão pulsionais. Neste artigo, Freud é levado a analisar como o princípio do prazer se relaciona com as pulsões de morte e as pulsões de vida. O prazer e o desprazer não poderiam mais ser referidos a um fator quantitativo, mas sim, qualitativo. Em suas palavras:

\footnotetext{
38 Delouya (2000, p.130) nos lembra que “a sublimação está presente, vinculando-se ao ideal desde o inicio da vida como resultado da pulsão de morte na purificação do eu-prazer”.
} 
Se pudéssemos dizer o que é essa característica qualitativa, estaríamos muito mais avançados na psicologia. Talvez seja o ritmo, a sequência temporal de mudanças, elevações e quedas na quantidade de estímulo. Não sabemos. (FREUD, 1924, p.200, grifos nossos)

Assim, "uma vez que tenhamos admitido a ideia de uma fusão das duas classes de instintos uma com a outra, a possibilidade de uma desfusão - mais ou menos completa se impõe a nós" (FREUD, 1923, p.56). Entretanto, Freud (1923, p.56) nos diz que

[...] tal hipótese não lança qualquer luz sobre a maneira pela qual as duas classes de instintos se fundem, misturam e ligam uma com a outra, mas que isto se realiza de modo regular e de modo muito extensivo constitui pressuposição indispensável à nossa concepção.

Seguiremos a pista indicada por ele:

[...] teremos de considerar se outras vicissitudes instintuais não podem resultar também dessa transformação (sublimação); se, por exemplo, ela não pode ocasionar uma desfusão dos diversos instintos que se acham fundidos. (FREUD, 1923, pp.44-45)

Foi através da noção de fusão e desfusão dos instintos que Freud pôde compreender os fenômenos do masoquismo e do sadismo. O princípio que antes tinha como objetivo a ausência total de excitação no aparelho psíquico é alterado pela intromissão das pulsões de vida e se torna princípio do prazer. Isto é, o princípio do Nirvana pertencente às pulsões de morte é modificado através da interferência das pulsões de vida e da libido. Eros representa as exigências da vida e age sobre a tendência à inércia e à desorganização. O princípio do prazer também se sujeita a modificações e, ao adequarse ao mundo externo, transforma-se em princípio da realidade. Contudo, a maneira pela qual uma pulsão se transforma na outra não nos é clara, não sabemos o que determina a quantidade de pulsão de morte que irá se submeter ao princípio do prazer e aquela que permanecerá desfusionada, resistindo às mudanças.

O masoquismo se apresenta de três formas: "como condição imposta à excitação sexual, como expressão da natureza feminina e como norma de comportamento" (FREUD, 1924, p.201). Iremos nos deter sobre o último, conhecido como masoquismo moral, onde identificamos o sentimento inconsciente de culpa em sua maior parte. Apesar de o termo sentimento inconsciente parecer incorreto, uma vez que não falamos em sentimentos inconscientes, este parece ser, para Freud, o melhor modo de descrevêlo. No masoquismo moral, observamos um afrouxamento da vinculação das pulsões, a 
sexualidade ou libido parece estar mais afastada dos seus propósitos de obter prazer. Entretanto, veremos que a satisfação será obtida de maneira sádica pelo superego:

A consciência e a moralidade surgiram mediante a superação, a dessexualização do complexo de Édipo; através do masoquismo moral, porém, a moralidade mais uma vez se torna sexualizada, o complexo de Édipo é revivido e abre-se o caminho para a regressão, da moralidade para o complexo de Édipo. (FREUD,1924, p.211)

O sadismo que deveria ser expresso para o mundo externo retorna contra o eu, uma vez que o princípio da realidade e as normas culturais exigem que as tendências destrutivas do indivíduo sejam impedidas de se realizar:

A destrutividade que retorna do mundo externo é também assumida pelo superego, sem qualquer transformação desse tipo, e aumenta seu sadismo contra o ego. O sadismo do superego e o masoquismo do ego suplementam-se mutuamente e se unem para produzir os mesmos efeitos. (FREUD,1924, p.212)

Para Freud (1924), o masoquismo moral é uma prova da existência da fusão dos instintos e o perigo que ele apresenta reside no fato de ter sua origem na pulsão de morte. O instinto de destruição que não pôde ser totalmente voltado para fora, atua na destruição do próprio eu, encontrando nisso uma satisfação libidinal sádica. Desse modo, o superego atua com severidade contra o eu, pois conhece os desejos profundos desse. Segundo Delouya (2000, p. 132), a consequência da desintrincação pulsional é "um acúmulo interno de agressividade ou destrutividade das pulsões de morte que, não encontrando vias de descarga motora externa, agem a serviço do ideal e contra o eu”.

A necessidade de punição tem como par e é explicada pelo sentimento de culpa que surge quando os ataques do superego ao ego encontram motivos para acusá-lo. Lembramos aqui que os desejos inconscientes podem ser sempre reconhecidos pela instância crítica e censora que sabe tudo sobre eles, uma vez que o superego é uma diferenciação do próprio eu. De acordo com Freud(1930, p.156), “o sentimento de culpa é uma expressão tanto do conflito devido à ambivalência, quanto da eterna luta entre Eros e o instinto de destruição ou morte".

Ele diz:

Quanto ao sentimento de culpa, temos de admitir que existe antes do superego e, portanto, antes da consciência também. Nessa ocasião, ele é expressão imediata do medo da autoridade externa, um reconhecimento da tensão existente entre o ego e essa autoridade. É o 
derivado direto do conflito entre a necessidade do amor da autoridade e o impulso no sentido da satisfação instintiva, cuja inibição produz a inclinação para a agressão. (FREUD,1930, p.161,grifos nossos)

Em “O Ego e o Id” (1923, p.57), lemos que "[...] a ambivalência é um fenômeno tão fundamental que ela mais provavelmente representa uma fusão instintual que não se completou". Nesse texto, o exemplo oferecido para pensarmos a oposição entre as duas classes de instintos, a pulsão de vida e a pulsão de morte, é o do amor e do ódio polaridades de cada pulsão. A observação clínica nos mostra que o amor sempre está acompanhado de ódio e que o ódio pode se transformar em amor e vice versa. ${ }^{39}$ Contudo, quando pensamos no mecanismo de transformação de amor em ódio, pressupomos que existiria na mente, no ego ou no id, "uma energia deslocável, a qual, neutra em si própria, pode ser adicionada a um impulso erótico ou destrutivo qualitativamente diferenciado e aumentar a sua catexia total.” (1923, p.59) Para Freud (1923, p. 60),

[...] parece uma concepção plausível que essa energia deslocável e neutra, que é sem dúvida, ativa tanto no ego quanto no id, proceda do estoque narcísico de libido - que ela seja Eros dessexualizado. (Os instintos eróticos parecem ser em geral mais plásticos, mais facilmente desviados que os instintos destrutivos)

Essa questão nos parece importante, já que a energia necessária para a transformação do amor em ódio provém da libido dessexualizada. Vemos também como os instintos destrutivos são menos plásticos, o que nos leva a pensar que eles buscam caminhos já trilhados anteriormente, como seria o caso da agressividade presente no agente censor do eu. Freud (1923, p 61) continua:

Se essa energia deslocável é libido dessexualizada, ela também pode ser descrita como energia sublimada, pois ainda reteria a finalidade principal de Eros - a de unir e ligar- na medida em que auxilia no sentido de estabelecer a unidade ou tendência à unidade, que é particularmente característica do ego.

\footnotetext{
${ }^{39}$ Klein (1937, p.347) sublinha a necessidade de trabalharmos a interação entre o amor e o ódio desde os momentos mais arcaicos de funcionamento psíquico. A compreensão do papel desempenhado pelos impulsos destrutivos nessa interação seria capaz de mostrar como os sentimentos de amor e as tendências de reparação se desenvolvem em ligação com os impulsos agressivos, ou apesar deles. Retomaremos esse ponto no terceiro capítulo deste trabalho.
} 
Como dito anteriormente, quando o ego é o intermediador que transforma a libido erótica em libido do ego - tornando-se o objeto amoroso único -, ele se coloca a serviço não de Eros, mas de Tanatos. As pulsões de vida buscam nos defender contra a destrutividade e a agressividade das pulsões de morte, seja ela dirigida ao interior ou ao exterior do eu. Elas nos convidam à reinvenção, ao rearranjo, à fala, à desalienação, à ligação das representações e afetos.

Rosenberg (2003) em "Masoquismo guardião de vida e masoquismo de morte", indica que seria necessário uma espécie de masoquismo primário para que o aparelho psíquico possa se constituir. A ideia é que a capacidade do bebê de sustentar um desprazer irá permitir a espera pelo retorno do objeto de satisfação fazendo com que as frustações do ambiente e o desprazer do desamparo trazidos pelas pulsões anárquicas não paralisem o pequeno sujeito. Ao poder sustentar um desprazer por um certo período de tempo, as primeiras representações e fantasias são criadas, retoma-se o traço deixado sulcado no aparelho psíquico pelo objeto. Recorremos a esse traço para buscar representar aquilo que não está mais ali. Como vimos, a possibilidade de representação do objeto ausente que era fonte de apaziguamento e prazer é sentido como uma alucinação.

O masoquismo como guardião de vida é um paradoxo. Entretanto, “o masoquismo moral é aquele ao qual as neuroses recorrem mais habitualmente quando o masoquismo se lhes é necessário" (ROSENBERG, 2003, p.40). O autor propõe uma separação entre a culpa e o masoquismo moral, na qual a primeira desempenharia uma transformação do sadismo em masoquismo e sua forma extrema seria encontrada na reação terapêutica negativa, em que o eu não se sentirá culpado, mas doente - reafirmando a relação entre esse sentimento de culpa e a necessidade de punição ${ }^{40}$. Já o masoquismo é "a melhor proteção contra a destrutividade, e em primeiro lugar contra a destrutividade interna, mas pode se tornar seu instrumento privilegiado". (ROSENBERG, 2003, p.118) Iremos discutir no item "O trabalho de melancolia", as ideias desse autor, as quais nos serão muito úteis para pensar a especificidade da sublimação na melancolia, o que nos permitirá perceber elementos importantes na obra de Ana Cristina César.

\footnotetext{
${ }^{40}$ A reação terapêutica negativa que tem como obstáculo o sentimento inconsciente de culpa é um fator que "tem de ser levado em conta em muitíssimos casos, talvez em todos os casos graves de neurose" (FREUD, 1923, p.66). Como as pulsões de morte agem da forma mais silenciosamente possível, talvez o aspecto moral seja o disfarce perfeito para que a morte opere: morre-se pela honra, pelos ideais, sofre-se por vergonha, etc...
} 
Na próxima sessão, traremos a definição que Freud dá à melancolia e buscaremos nos autores pós-freudianos as noções que expandirão nossa compressão sobre os termos dessa pesquisa. 


\title{
2.2 Uma psiconeurose narcísica
}

\begin{abstract}
Para aqueles a quem a melancolia devasta, escrever sobre ela só teria sentido se o escrito viesse da melancolia. Tento lhes falas falar de um abismo de tristeza, dor incomunicável que às vezes nos absorve, em geral de forma duradoura, até nos fazer perder o gosto por qualquer palavra, qualquer ato, o próprio gosto pela vida. Esse desespero não é uma aversão, que pressuporia capacidades de desejar e de criar, de forma negativa, claro, mas existentes em mim. Na depressão, o absurdo de minha existência, se ela está prestes a se desequilibrar, não é trágico: ele me parece evidente, resplandecente e inelutável. Donde vem esse sol negro? De que galáxia insensata seus raios invisíveis e pesados me imobilizam no chão, na cama, no mutismo, na renúncia. (KRISTEVA, 1989,p.11)
\end{abstract}

Os gregos percebiam a melancolia como a verdadeira natureza do ser. Freud (1917[1915]) nos dizia que o melancólico seria aquele que não fazia mais que, talvez, apreender a verdade com mais acuidade que aqueles que não o são.

Assim, talvez tenhamos nas saídas encontradas na melancolia, algumas respostas que poderão iluminar tanto a clínica das afecções narcísicas - que requer modos de intervenção distintos da que encontramos no paradigma neurótico clássico-, quanto a própria clínica da neurose. Acreditamos que as diferentes matrizes clínicas encontramse em uma base de sustentação comum, um solo - muitas vezes movediço - que parece trazer à tona os momentos e os impasses arcaicos da constituição psíquica. A localização nosográfica da melancolia também se assenta em um terreno não muito seguro. Deparamo-nos com uma profusão de interpretações sobre a problemática do chamado "complexo melancólico" proposto por Freud (1917[1915]). Ora considerada uma psicose, ora misturada a concepções da tradição psiquiátrica, o que as dissonâncias nos mostram é que precisamos nos mover lentamente para alcançar aquilo que a especificidade do discurso melancólico coloca em relevo. Nas palavras de Lambotte (1997, p.11)

Com efeito, como abordar a melancolia se, já disposta entre as psicoses, ela apela aos princípios gerais de explicação tanto psiquiátricos quanto psicanalíticos? Considerar a melancolia como uma psicose, a despeito das múltiplas formas sintomáticas de que ela pode revestir, não contribui para fazer progredir sua compreensão, se não, ao contrário, contribui para banalizar o modo de aproximação a ela. 
As inúmeras variações dos quadros melancólicos nos impelem a uma escuta que busque entender quais seriam os fundamentos constitucionais dessa patologia, quais os seus modos privilegiados de defesa e de relações objetais, enfim, sua dinâmica, economia e tópica envolvidas. Como veremos, as dimensões do outro que foram introjetadas, identificadas e incorporadas deverão ser consideradas na composição da problemática melancólica, uma vez que o conflito psíquico na melancolia está localizado entre o ego e o superego. Concordamos com Lambotte (1997, p.392):

Assim, pois, atrás das explicações metapsicológicas da melancolia precedentes, da insuficiência das representações originárias da primeira tópica freudiana - às quais voltaremos em termos de significantes - a impossível imagem narcísica da segunda tópica, e do modelo lacaniano que remete a organização psíquica do sujeito a um tempo especular, perfila-se uma outra perspectiva, dinâmica desta vez, que permite apreender as fontes e as relações energéticas específicas de tais processos.

Assim, para seguirmos na releitura das contribuições ao tema, traremos alguns argumentos que irão nortear nossa aproximação à melancolia, a representante privilegiada da categoria das "psiconeuroses narcísicas":

O comportamento do supereu deveria, contrariamente ao que ocorreu até o momento, ser levado em consideração em todas as formas de doença psíquica. À espera disso, sempre podemos postular que deve haver afecções que repousam em um conflito entre o eu e o supereu. A análise nos autoriza a admitir que a melancolia é um caso exemplar deste grupo; gostaríamos muito de poder dar a este gênero de distúrbios o nome de 'psiconeuroses narcísicas'. Com efeito, não seria absolutamente contraditório com nossos sentimentos que encontremos motivos para separar estados como a melancolia das outras psicoses. Mas agora assinalemos que podemos aperfeiçoar nossa fórmula genética simples sem deixá-la ruir. A neurose de transferência corresponde ao conflito entre o eu e o isso, a neurose narcísica ao conflito entre o eu e o supereu, a psicose entre o eu e o mundo exterior. Certamente que não podemos dizer de imediato se efetivamente adquirimos conhecimentos novos ou se somente enriquecemos nosso formulário, mas penso que esta possibilidade de aplicação nos deve encorajar a manter em vista nossa partição do aparelho psíquico em um eu, um supereu e um isso. (FREUD, 1924.p.192)

A primeira obra freudiana que tratou do assunto foi o "Rascunho G" (1895), considerado, por ele mesmo, uma apreciação prematura no que se refere às observações clínicas do fenômeno. Ali, ele observa que o afeto correspondente à essa patologia é o 
do luto: o desejo de recuperar algo que foi perdido. Trataria-se de uma perda na vida pulsional, isto é, consistiria em luto por perda da libido. (Cf: FREUD, 1895, p.223) Os efeitos desse processo seriam a inibição psíquica com empobrecimento pulsional e sofrimento. Para explicar estas manifestações, Freud supõe que o aparelho psíquico, ao se defrontar com uma grande perda da quantidade de excitação, se defende através de uma espécie de "retração para dentro" na esfera psíquica, que produz efeitos sobre as quantidades de excitação contíguas. Como uma hemorragia interna, um empobrecimento da excitação se instala no depósito da libido que agora está livre, manifestando-se nas outras funções, diz Freud (1985, p.227): "Essa retração para dentro atua de forma inibidora, como uma ferida, num modo análogo ao da dor”. A dor foi considerada por ele como uma pseudopulsão, reforçando o caráter econômico de urgência que deve ser observado nesse fenômeno.

Sobre a dor psíquica, Cintra (2000, p.62) nos lembra que na teorização freudiana o primeiro envelope psíquico, o chamado "escudo pára-excitação" foi atravessado em um ponto, de onde parte um fluxo de excitações invadindo o aparelho psíquico, da periferia para o centro. Contudo, a dor não virá da ruptura dessa camada protetora, mas do acúmulo de energia interna que vem ao encontro da energia invasora para tentar imobilizá-la através de um processo de ligação. A ligação limita o fluxo da energia livre, buscando representações que possibilitarão a operação do processo secundário. Esse primeiro envelope psíquico mantém num sistema fechado interno o aumento pulsional até o ponto onde a descarga se torna necessária. A descarga pulsional só é possível através da presença e disponibilidade do objeto. $\mathrm{O}$ que provocaria a dor seria o encontro da energia quiescente interna que tenta dominar a energia livre que vem de fora. A dor não seria decorrente do aumento absoluto de energia, mas do encontro da energia livre com a energia mobilizada de dentro para fazer o bloqueio e a ligação da que vem de fora. A energia que atravessa o pára-excitação deixa passar uma excitação que dependendo da sua intensidade e natureza, produz ou o prazer de excitação da pele e dos órgãos do sentido e motricidade ou a dor.

Anos depois, em "Luto e melancolia" (1917[1915]) compreendemos que a melancolia compartilha de várias condições externas presentes no luto. Quando ocorre o fato de um ente querido falecer, ou um grande amor acabar, o mundo externo se torna vazio e sem apelo, não há disposição para realizar novas atividades e as funções orgânicas como o sono e a fome podem ficar alteradas. Essas reações não são 
consideradas patológicas quando não se prolongam no tempo. Na melancolia, o trabalho de luto não se completa.

Entre os traços distintivos da melancolia, encontramos, segundo Freud (1917[1915],p.276):

[...] desânimo profundamente penoso, a cessação de interesse pelo mundo externo, a perda da capacidade de amar, a inibição de toda e qualquer atividade, e uma diminuição dos sentimentos de autoestima a ponto de encontrar expressão em auto-recriminação e autoenvilecimento, culminando numa expectativa delirante de punição ${ }^{41}$.

No luto normal a libido investida no objeto amoroso que foi perdido será aos poucos desvinculada, desligada. O doloroso processo de desfazer ligações deixa o eu inibido e desinteressado pelo mundo externo. Isso demonstra como o ego não abandona facilmente uma posição libidinal, nem mesmo quando um substituto já está presente. A libido que é retirada do objeto se volta para o eu e, quando terminado o trabalho do luto, o ego fica novamente livre para investir em outros objetos. Na melancolia, além do desinteresse e inibição, observamos uma diminuição da auto-estima que acompanha a perda do objeto de amor. Freud (1917[1915], p.280) nos dirá que "no caso da melancolia, a insatisfação com o ego constitui, por motivos de ordem moral, a característica mais marcante". A baixa-estima e as auto-acusações do melancólico seriam frutos de uma "identificação narcísica" com o objeto perdido, objeto introjetado ${ }^{42}$ que era ao mesmo tempo amado e odiado. "Dessa forma, uma perda objetal se transformou numa perda do ego, e o conflito entre o ego e a pessoa amada, numa separação entre a atividade crítica do ego e o ego enquanto alterado por uma identificação" (FREUD, 1917[1915], p.282).

O mecanismo conhecido como "identificação narcísica" é um processo que visa apreender o objeto dentro de si para que sua ausência não seja sinônimo de catástrofe. A identificação narcísica traz consigo a relação - sempre ambivalente - que se mantinha

\footnotetext{
${ }^{41} \mathrm{~A}$ capacidade de amar, assim como de sublimar dos melancólicos são temas que geralmente carregam uma polêmica - já que esse trecho do texto freudiano é tomado na sua literalidade. Moreira (2002) nos ajuda pensar este ponto. Segundo a autora, "quando estamos melancólicos perdemos a capacidade de amar parcialmente, ficamos na posição de desamparo dos bebês, um verdadeiro bebê melancólico, que pede amor do tipo oral e fusional, intenso e incondicional. Mas quando saímos do processo mais excessivo, patológico, de melancolia, podemos recuperar a capacidade de amar como adultos, como relações de objeto, sem precisar fundir com o outro; recuperamos a capacidade de nos amara nós mesmos também, sem fusão, guardando certa distância do outro e reconhecendo ele como objeto com existência própria". (MOREIRA, 2014, comunicação pessoal)

${ }^{42}$ A introjeção será considerada como um processo de apropriação e consequente expansão psíquica, enquanto a incorporação será correlata da impossibilidade de assimilação do que é trazido pelo mundo externo, pelo objeto.
} 
com o objeto de amor. A ambivalência de sentimentos, assim, colore a introjeção que é feita do objeto perdido. Várias equações podem ser pensadas a partir daí. Uma delas diz respeito à cisão entre os sentimentos contraditórios que são dirigidos ao objeto, mas que, por este estar agora "habitando" o interior psíquico do melancólico, é atacado na sua porção que está identificada ao ego - desse modo entenderíamos as auto-acusações, o auto-envilecimento, as recriminações melancólicas. Através da melancolia, Freud (1917[1915]) entende que o ego só pode atentar contra a própria vida se dirigir para si mesmo toda a agressividade que dirigiria a um objeto externo, isto é, tratar a si mesmo como tal. Esse mecanismo ocorre devido ao retorno ao eu do investimento da libido que estava dirigida para o exterior, ligada ao objeto. Se não fosse a operação de identificação com o objeto (mais especificamente, com a sua faceta odiada) que se efetua nesse momento, o ego ainda seria aquele que se auto-preservaria e buscaria as condições para evitar a dor e buscar o prazer.

Na melancolia, o luto vivido pode ser reativo à perda de um objeto real, mas parece estar mais relacionado à uma perda de natureza ideal. Nessa condição, pode-se saber até quem, mas não o que foi perdido nesse alguém. Segundo Freud (1917[1915], p.278), “isso sugeriria que a melancolia está de alguma forma relacionada a uma perda objetal retirada da consciência, em contraposição ao luto, no qual nada existe de inconsciente a respeito da perda". Como dissemos, no luto, o teste da realidade se processa aos poucos e seu penoso trabalho libera aos poucos a libido do objeto perdido. Já na melancolia, o complexo funciona como uma ferida aberta que exige um contra-investimento ${ }^{43}$ muito alto para que o eu não seja esvaziado de toda a sua energia libidinal. Diferentemente do luto simples e do luto patológico, há uma perda de auto-estima que acompanha a tristeza, isto é, existe uma alteração no eu. As auto-recriminações e as auto-acusações dos melancólicos seriam "[...] recriminações feitas a um objeto amado, que foram deslocadas desse objeto para o ego do próprio paciente.” (1917[1915], p.280) O que muitas vezes é chamado de um "delírio de inferioridade" seria uma tentativa de atacar o objeto de amor que se tornou um objeto abandônico e por essa razão é odiado pelo eu. A relação objetal é desfeita quando após a escolha objetal - uma ligação da libido a um

\footnotetext{
${ }^{43}$ Contra-investimento é um "processo econômico postulado por Freud como suporte de numerosas atividades defensivas do ego. Consiste no Investimento pelo ego de representações, atitudes, etc., susceptíveis de impedirem o acesso à consciência e à motilidade das representações e desejos inconscientes. O termo pode igualmente designar o resultado mais ou menos permanente desse processo". (LAPLANCHE, PONTALIS, 1988, pp.144-145)
} 
objeto particular - se segue um desapontamento proveniente desse objeto de amor. Essa dinâmica nos será cara para a apreciação da obra de Ana Cristina César.

Diante da ruptura da relação de amor, o eu precisa haver-se com a perda do objeto. Esse processo é descrito por Freud (1917[1915], p.281) do seguinte modo:

A catexia objetal provou ter pouco poder de resistência e foi liquidada. Mas a libido livre não foi deslocada para outro objeto; foi retirada para o ego. Ali, contudo, não foi empregada de maneira não especificada, mas serviu para estabelecer uma identificação do ego com o objeto abandonado. Assim, a sombra do objeto caiu sobre o ego, e este pôde, daí por diante, ser julgado por um agente especial, como se fosse um objeto, o objeto abandonado.

Para Freud (Cf.: 1915, p.182), temos que considerar três elementos como précondições necessárias à melancolia: a perda do objeto, a regressão da libido ao ego - e com ela a identificação narcísica - e a ambivalência de sentimentos. Para as duas primeiras condições deve ter estado presente uma forte fixação no objeto amado, e contraditoriamente, a catexia objetal deve ter tido pouco poder de resistência. Sobre a ambivalência e a identificação narcísica, Freud (1915, p.184) diz:

Esse conflito devido à ambivalência, que por vezes surge mais de experiências reais, por vezes mais de fatores constitucionais, não deve ser excluído entre as pré-condições da melancolia. ${ }^{44} \mathrm{Se}$ o amor pelo objeto - o um amor que não pode ser renunciado, embora o próprio objeto o seja - se refugiar na identificação narcisista, então o ódio entra em ação nesse objeto substitutivo, dele abusando, degradando-o, fazendo-o sofrer, e tirando satisfação sádica de seu sofrimento.

Lembramos que a ambivalência de sentimentos está presente desde as primeiras identificações. Na gênese do amor construída por Freud em "O Instinto e suas vicissitudes" (1915), reconhecemos a fase de incorporação como a primeira de muitas, onde o amor é compatível com a abolição da existência separada do objeto. Qualquer separação é percebida como desprazer e pode então despertar angústia e ódio no eu, que irá atacar o objeto que provocou o mal-estar. Isto é,

Quando a fase puramente narcisista cede lugar à fase objetal, o prazer e o desprazer significam relações entre o ego e o objeto. Se o objeto se torna fonte de sensações agradáveis, estabelece-se uma ânsia(urge) motora que procura trazer objeto para mais perto do ego e incorporálo ao ego. (1915, p.158)

\footnotetext{
${ }^{44}$ Pensaremos mais à frente em uma ambivalência primária, relacionada aos fatores constitucionais e uma ambivalência secundária, referente às experiências reais, derivada da problemática edípica.
} 
O objeto que proporciona prazer nos atrai e nós o amamos. Inversamente, se ele for fonte de desprazer, há um esforço do eu para aumentar a distância entre si e o outro, repetindo o modelo de fuga dos estímulos aversivos externos. Esse objeto que é repelido é também odiado. De acordo com Freud (1915, p.160),

O ego odeia, abomina e persegue, com intenção de destruir, todos os objetos que constituem uma fonte de sensação desagradável para ele, sem levar em conta que significam uma frustração quer da satisfação sexual, quer da satisfação das necessidades auto-preservativas. Realmente, pode-se asseverar que os verdadeiros protótipos da relação de ódio se originam não da vida sexual, mas da luta do ego para preservar-se e manter-se.

Os ataques brutais da instância crítica que são deferidos ao eu melancólico visam, então, dois alvos: o outro que foi responsável pelo abandono - mas agora faz parte do eu - e o próprio eu. Esses ataques teriam a finalidade de punir dois responsáveis de uma só vez. Lemos em Freud:

Descobrimos que as autocensuras com que esses pacientes melancólicos se atormentam a si mesmos da maneira mais impiedosa, aplicam-se, de fato, a outra pessoa, o objeto sexual de que se tornou sem valor para eles por sua própria falha. (FREUD, 1917[19161917], p. 498, grifos nossos.)

$\mathrm{Na}$ ambiguidade da expressão "sua própria falha", lemos a consideração das duas possibilidades mencionadas acima. A primeira tratar-se-ia da culpabilização do eu pelo abandono do objeto de amor que era, ao mesmo, tempo amado e odiado, fator sobre o qual insistiremos. A segunda se refere ao mencionado pouco "poder de resistência do investimento objetal", isto é, o objeto não suportou o investimento que lhe era requisitado, tendo a vertente do ódio vencido a do amor. A fragilidade do investimento ao objeto é uma condição da melancolia que encontramos também nas fases iniciais da vida do sujeito. As alterações percebidas na qualidade dessa primeira relação com o outro que é simultaneamente o objeto de investimento e fonte de identificação podem trazer consequências significativas para o eu que se constitui. Vimos com Freud que a necessidade de separação do objeto de amor é uma renúncia à qual todo o ser humano é submetido para que possa entrar na cultura. Essa separação acarreta uma transformação no eu. $\mathrm{O}$ eu se divide em uma parte, que busca resguardar o objeto dentro de si e 
garantir sua permanência, e uma outra parte, que se transforma no objeto perdido, que critica e julga. O eu, diante da necessidade de desligar-se de seus objetos de amor, precisa efetuar um dessexualização da libido que se ligava aos antigos objetos para depois investir em novos objetos. No entanto, seria esse o mecanismo responsável por uma desfusão pulsional que se infiltraria deixando marcas na instância crítica desse tempo tão arcaico?

Freud (1917[1915], p.282) nos mostra como na perturbação melancólica podemos obter uma compreensão a respeito da constituição do eu, onde uma parte do eu se coloca contra a outra, julga-a e a toma como seu objeto: "Dessa forma, uma perda objetal se transformou numa perda do ego, e o conflito entre o ego e a pessoa amada, numa separação entre a atividade crítica do ego e o ego enquanto alterado pela identificação". Lembramos que, "no caso da melancolia, a insatisfação com o ego constitui, por motivos de ordem moral, a característica mais marcante" (1917[1915], p.280).

A partir do momento em que se pode perceber a existência do objeto existe a possibilidade de uma ferida narcísica - que poderá ser parcialmente cicatrizada com o ideal do eu (Cf: MOREIRA, 2002). Essa ferida narcísica primordial que recorre a uma instância superior para se conter também confere a ela poderes especiais de observação e censura. É o superego que irá avaliar se o eu está de acordo com o ideal de eu. O objeto, por ser um elemento externo e variar na qualidade e quantidade de seu cuidado e presença, precisa entrar dentro de um circuito de ordenações previsíveis e capazes de contenção. $\mathrm{O}$ eu, passivo e submetido às vontades tanto do objeto quanto do id, tem como recurso a transformação da atitude passiva em ativa, atribuindo a si mesmo a responsabilidade pelo que venha acontecer com o objeto. Como observado na megalomania e na onipotência de pensamentos presentes nas patologias narcísicas, o ego toma para si a responsabilidade pelos destinos dos objetos que estão ao seu lado.

\subsubsection{Ambivalência, culpa, vergonha e masoquismo}

Como vimos anteriormente, tanto a instância crítica quanto o sentimento de culpa são trazidos por Freud ao longo da primeira tópica como tributários do complexo edípico. A culpa seria o resultado dos sentimentos ambivalentes em relação ao objeto de amor que 
é também fonte de identificação. O desejo de ocupar o lugar do pai, o qual é amado e temido, leva o eu a reprimir suas tendências agressivas, que tomam a forma de um sentimento de culpa. É somente na segunda tópica psíquica que localizaremos o sentimento de culpa ao lado das pulsões destrutivas no eu. Pensamos que, na melancolia, o complexo de Édipo reatualiza as perdas originárias, isto é, "perde-se" novamente o objeto de amor ou algo ligado ao ideal onde antes o eu se refugiava. $\mathrm{O}$ eu que se responsabilizou pela partida do objeto de amor para obter algum domínio e contenção da situação de desamparo pode se ver aprisionado a uma identificação com o objeto que está na origem da formação do próprio eu, impossibilitado de desidentificar$\mathrm{se}^{45}$. Vimos que a consequência dessa operação é o eu se colocar a serviço das pulsões do id. No tempo do complexo de Édipo, a perda do objeto de amor encontra novamente um terreno de ambivalência de sentimentos, onde o eu irá novamente ficar em dívida com o outro, se culpando através da instância crítica superegóica - que agora contém o ideal do eu. Assim, podemos dizer que o sentimento de culpa que é anterior ao complexo de Édipo encontra, nesse último, a ocasião para se reeditar. Sabemos que o ego busca evitar, de todas as formas, a perda de seu objeto de amor ao identificar-se com ele, mas quais seriam os elementos que permitiriam ao eu desidentificar-se desse objeto incorporado?

Após esse processo conhecido como complexo melancólico, o superego, a instância crítica do eu, pode ser visto na sua faceta mais terrível: uma "pura cultura da pulsão de morte”. (Cf: FREUD, 1917 [1915], passim) A culpa do melancólico, então, estaria referida tanto à responsabilidade pela ausência do objeto quanto pelos seus desejos proibidos. Contudo, no melancólico haveria um desejo primário mais urgente, o desejo de ser. Veremos com Vertzman $(2002,2009)$ que o desejo de ser traz ao mesmo tempo a culpa de sê-lo. Se o objeto não está mais lá, como antes ou como o eu precisava que ele estivesse, então, o eu em constituição, por estar vivenciando o período da onipotência de pensamentos ${ }^{46}$ irá atribuir a si a causalidade do movimento de afastamento do objeto de

\footnotetext{
${ }^{45}$ Esse termo parece ter sido usado pela primeira vez por Octave Manonni. Ele entendia a identificação como um processo inconsciente sendo que a sua conscientização produziria uma desidentificação. Só seria possível saber a que se está identificado no momento em que não se está mais identificado ao objeto. Manonni (1987/1994) chama atenção para o fato da identificação ser um tipo de pensamento que não necessita de justificativa, pois a causa permanece sempre obscura; ela só vem a ser consciente quando o sujeito desidentifica-se.

${ }^{46} \mathrm{Na}$ onipotência de pensamentos, ainda não está clara a distinção dentro e fora, eu e outro. O sentimento de onipotência é um importante fator na estruturação do sujeito, pois é preciso num primeiro momento acreditar que as ações do mundo externo são efeitos do próprio desejo, ou seja, é preciso que exista um ambiente que propicie ao pequeno sujeito a ilusão de que ele cria os objetos da realidade.
} 
amor. As auto-recriminações surgem também como uma forma de punição dessa culpa por ter feito o outro desaparecer. Como ele não sabe por quê, é ao seu corpo e suas características pessoais que recorre, buscando a origem do que poderia ter repelido a mãe, justificado o abandono ${ }^{47}$. Um dos maiores sofrimentos do melancólico é sentir que ele não teve nenhum poder de influência sobre a decisão do outro, que ele não foi motivo para a felicidade da mãe nem foi capaz de despertar seu amor (um amor “suficiente”), mas o contrário disso. Vertzman (2002, p.74) nos ajuda a pensar a culpa:

O elemento impossível de ser introjetado, como notado, é a culpa edípica do adulto. A criança não possui vocabulário para correlacionar a linguagem da mímesis com o crime da sexualidade, entretanto, ela é capaz de assumir todos os outros aspectos da culpa, tais como a comiseração, a imputação compulsiva de responsabilidade a si, a percepção de ter cometido um ato condenável, dentro da sua forma de usara linguagem. [...]a culpa passional do adulto é degradada no universo psíquico da criança tornando-se culpa por ser. Percebo alguma afinidade entre esta modalidade paradoxal de culpa e a culpa narcísica, definida por Freud como angústia diante da perda do amor parental. [..] $\mathrm{O}$ apego que a criança adquire pela nova posição advém do fato de que foi através da culpa de ser que ela pôde se separar paradoxalmente do outro, que ela pôde assumir sua única identidade possível, que ela pôde reconhecer a presença de um desejo a ela dirigido.

Segundo o autor (2002), a culpa é o índice que permite ao sujeito se identificar. Quando o outro adulto não reconhece o pequeno sujeito como alguém com necessidades próprias, estaremos face a uma desautorização que atua na capacidade de dar sentido e no próprio sentido do existir. Em suas palavras,

Quando a onipotência introjetiva não encontra qualquer elemento no mundo que a sustenta - neste caso o reconhecimento por parte de um terceiro - ocorre um curto-circuito na construção do sentido. Quando o desmentido atinge uma área onde a afirmação de si seja prioritária, neste caso a verdade das próprias sensações, o que é desmentido é o próprio sujeito. Para que o desmentido seja performativo e o trauma se efetive não é necessário que este terceiro emita sentenças específicas a respeito da criança. Basta que não a encare como uma pessoa com necessidades próprias. A ausência de reconhecimento característica do trauma não é um problema senso perceptivo. Diante dos obstáculos típicos da vida, o infans escuta precocemente que ele deve se adequar ao mundo tal qual ele é, que nada pode fazer para transformá-lo, que o único modo de existir é na quietude, que deve

\footnotetext{
${ }^{47}$ Freud (1923) nos conta como na reação terapêutica negativa estaria em jogo um sentimento de culpa tão poderoso que impediria o paciente de se beneficiar de sua melhora. Freud sempre fazia menção ao "complexo melancólico" para tentar compreender esse fenômeno clínico - a reação terapêutica negativa que subverte todas as noções anteriores sobre a teoria e a técnica.
} 
aceitar prontamente aquilo que lhe é oferecido. $\mathrm{O}$ traumatizado se agarra à ideia de que tudo que lhe ocorre é fruto de um destino que nada quer e que precisa utilizá-lo como intérprete para provar o seu poder. (VERTZMAN,2002,p.69)

Veremos mais adiante como a dimensão do desmentido está presente de diversas formas na melancolia.

De acordo com Vertzman (2002), o masoquismo seria o testemunho de uma falha da estrutura neurótica. A diferença entre a culpa e o masoquismo estaria no seu lugar de satisfação. A culpa viria depois da satisfação libidinal que tem um objeto próprio. $\mathrm{Na}$ culpa e na consciência moral, iremos observar o sadismo acrescido do supereu - ao qual o eu se submete. No masoquismo moral o acento recairia, contrariamente, sobre o masoquismo do próprio eu, que irá reclamar uma punição - seja do supereu ou do exterior propriamente dito.

Pensamos que a ambivalência em relação à figura paterna seria distinta daquela que observamos na relação mãe-filho. A separação necessária com o objeto primordial de amor - sabemos com Klein (1940) - gera angústias paranóides e também depressivas. O objeto que passa a ser percebido como distinto do eu, surge como um objeto total que contém, dentro de si, tanto as partes boas (nutrição, cuidado, amor) quanto as partes más (frustração, abandono, ódio). Podemos entender, assim, que haveria uma ambivalência "primária" relacionada a um momento constitutivo arcaico, cuja resultante seria o "ser ou não ser". A ambivalência "secundária”, relativa ao complexo Édipo e sua dissolução, estaria direcionada ao desejo inconsciente, aos desejos incestuosos - cuja realização exacerbaria a culpa de se estar ocupando o lugar do pai, superando-o - e aos desejos que vão na direção oposta aos modelos estabelecidos pelo ideal do eu.

De acordo com França Neto (2005,p. 101) "é a vertente do ódio direcionada ao pai que também é amado que precipita no sujeito um sentimento de culpa potencialmente paralisante". Entretanto, pensamos que o ódio da ambivalência "primária" é tão ou mais mortificador do que aquilo que chamamos aqui de ambivalência secundária. $\mathrm{Na}$ neurose obsessiva, a onipotência de pensamentos engendra um mecanismo ritualístico que tem como objetivo afastar ou dificultar a realização mágica dos pensamentos violentos que aparecem na fantasia de aniquilamento do outro. Na melancolia, ela assoma ao eu a culpa pelo destino do objeto, atuando como defesa frente à falta de controle sobre o objeto de amor. A presença ou a ausência do objeto passam a ser interpretadas como efeito ou resposta aos movimentos do esboço de eu que busca regularidade e constância para se configurar. Desse modo, vemos acontecer uma 
inversão de papeis: temendo o afastamento e a morte daquele que é responsável pelo seu cuidado, o bebê passa a se adequar ao ambiente que o acolhe, e não o contrário - cujo corolário seria a ideia da "mãe suficientemente boa". A progressão traumática de que nos fala Ferenczi (1933, p.103) é um modelo de entendimento do destino que virá a ter essa composição subjetiva especial, que parece ser composta somente de id e superego. Essa compreensão será retomada na análise da obra de Ana C.

O ódio, não podendo ser dirigido ao exterior, retorna para o eu ameaçando-o de desintegração. Essa ameaça de aniquilamento geraria as "agonias impensáveis" deque nos fala Winnicott, as quais têm a cisão como mecanismo de defesa básico para enfrentá-las. $\mathrm{O}$ ódio direcionado ao interior do psiquismo não funcionaria apenas como a voz que desautoriza, recrimina e dilacera o eu, mas também como uma força cuja potência desfaz as ligações construídas, desconstrói unidades e pode contaminar o psiquismo - que passa a convocar as lembranças penosas e transformar em fragmentos vexatórios a memória e a narrativa da história de si construída.

Pensamos que o sentimento inconsciente de culpa que está na base da resistência mais poderosa ao tratamento analítico seria tributária do primeiro momento de separação, da culpa arcaica relacionada à possibilidade de destruição do outro, um que se diferencia do eu, mas faz parte do mesmo. Sabemos que a diferenciação é um processo lento que irá envolver o já mencionado mecanismo de identificação de forma que esse outro seja metabolizado e passe a compor os traços diretrizes do eu. Contudo, iremos perceber que esse mecanismo de introjeção inclui o risco de uma "incorporação" do objeto externo, que será mantido encapsulado, enquistado numa "cripta" (TOROK, ABRAHAM, 1987) ${ }^{48}$ que impede sua movimentação, a transformação do estranho em familiar. Compreendemos que a tentativa de supressão do ódio que seria responsável tanto por uma retaliação do objeto quanto pela distinção necessária entre o eu e o objeto externo produz uma dinâmica delicada.

\footnotetext{
${ }^{48}$ De acordo com os autores (TOROK, ABRAHAM, 1987, p.239), "na tópica, essa cripta corresponde a um lugar definido. Não é nem o Inconsciente dinâmico, nem o Ego da introjeção. Seria antes como um território encravado entre os dois, espécie de Inconsciente artificial, instalado no próprio seio do Ego. A existência de tal túmulo tem por efeito obturar as paredes semipermeáveis do Inconsciente dinâmico. Nada deve filtrar para o mundo exterior. É ao Ego que retorna a função de guardião do cemitério. Ele se mantém plantado ali para fiscalizar as idas e vindas da família próxima que pretende - por razões diversas - ter acesso ao túmulo. Se ele consentir em introduzir aí os curiosos, os prejudiciais, os detetives, será para lhes poupar falsas pistas e túmulos fictícios. Aqueles que tem direito à visita serão objetos de manobras e de manipulações variadas. Eles também serão constantemente mantidos presentes no interior do Ego. Vê-se que a vida de um guardião de túmulo - por ter que compor com essa multidão diversa deve ser feita de malícia, de astúcia e de diplomacia. Seu lema: para esperto, esperto e meio".
} 
Quando o suporte identitário, a função de cuidado e o espelhamento oferecido pelo objeto materno não possuem qualidades que o permitiria ser introjetado - compondo assim o narcisismo e a auto-estima - o eu pode ver-se aprisionado a esse outro, incapaz de deixá-lo partir, se separar. É o objeto investido narcisicamente que precipita uma identificação que irá garantir para o eu a presença do outro, embora esse outro venha cindido em suas partes boas e más. O eu também irá sofrer uma cisão, e a parcela má identificada ao eu será tratada como se fosse um objeto externo, explicando as autoacusações e recriminações que podem chegar ao ponto extremo de um "delírio de inferioridade", como nos diz Freud. A parcela boa parece não ter a força de doação de vida necessária para combater o superego que se tornou uma "cultura pura da pulsão de morte", podendo ainda, paradoxalmente, funcionar como a energia de vida que irá sexualizar o sofrimento trazido pela culpa. Aqui trazemos, brevemente, a voz de Ana C. em uma carta escrita para Maria Cecília Fonseca, em junho de 1976:

Eu só queria dizer que estou ciente de uma grande solidão, falta de laços, [...] Acho que a distância me tira a vergonha de falar da solidão. É difícil falar disso tudo pra alguém perto, fica parecendo um apelo, um pedido, uma velada exigência ou reclamação. Como explicar para alguém perto que me sinto sozinha e que isso não significa que não somos amigos, não significa que não gosto de ninguém, não oculta uma reclamação?(talvez ocultasse se eu formulasse tudo isso.) (Era isso que eu queria dizer na primeiríssima e rejeitada folha e não consegui. Está dito, enfim.) Sei é que com as pessoas que estão aqui perto eu me sinto muito insegura. Deve ser estranho pra você receber cartas minhas tão flutuantes. Na minha cabeça parece que em cada carta transmito uma coisa diferente. Essa instabilidade intensa também é real, é cotidiana. Essa solidão que eu falo não é fato novo: ficou evidente, privado, inescapável. Antes era escamoteado, público, irremediável. Acho que eu tenho curiosidade de saber se todas essas coisas minhas são tão públicas assim. Até que ponto todo mundo percebe, Cecília?(CÉSAR, 1999b, p. 116)

A poeta dizia que as cartas e biografias são mais arrepiantes que a literatura, ela manifestava um desejo de que suas cartas fossem publicadas. Em outro momento, em março de 1977 termina uma carta para Clara Alvim, outra professora de literatura de quem fica amiga, assim: "Desculpa o estilo - morro pela boca, por essa boca. Me sinto triste e a palavra vilipendia minha tristeza. Me escreve? Beijos"(CÉSAR, 1999b, p.25). O significado de "vilipendiar" é "tratar alguém com desprezo, considerar (algo ou 
alguém) como vil, indigno, sem valor" (HOUAISS, 2001, p.2662). A palavra recrudesceria a tristeza da escritora? Retomaremos essa discussão no capítulo 5.

Será que o resultado da ambivalência primária estaria mais próximo da vergonha e a ambivalência secundária estaria mais próxima da culpa? Florence (1994, p.131) aponta que a melancolia está ligada aos modos mais arcaicos de ambivalência, isto é, "a identificação melancólica reconduz aos modos mais arcaicos da ambivalência, cliva o eu em uma parte sádica, identificada com o objeto, e em uma parte perseguida pela fantasia do objeto", o que nos leva a entender a rigidez do ideal melancólico. Sobre esse ponto Vertzman (2009, p.171) contribui dizendo que:

O melancólico apresenta-se como portador de um código moral bastante rígido, que não apenas servirá para instrumentalizar a critica mordaz que dirige aos outros, como também - e sobretudo - a si próprio. Há nele uma preocupação permanente com a noção de ridículo, tanto no que se refere ao ser ridículo quanto ao próprio ridículo da vida. Ele está ligado a um código moral.

A vergonha diz respeito ao sentimento de não estar à altura de nossas pretensões, a partir da proposta de Vertzman (2009), ela está relacionada com o olhar (ser olhado), sendo que os sentimentos de desgosto ou desprezo por si são projetados no outro. A vergonha é relativa ao que se é e suscita o desejo de transformação, mas é imperdoável, não pode ser expiada. Para o autor,

o sujeito depressivo da contemporaneidade sofre com a vergonha. $\mathrm{O}$ papel importante que o olhar do outro ocupa em sua vida remete para a questão da subjetividade exteriorizada, também perceptível na melancolia, mas de forma diferente. Na depressão, a presença do outro é perturbadora porque apontaria para alguma coisa em que ele seria falho, em que não teria tido a performance esperada, ainda que não tenha clareza sobre sua falha. Na melancolia, a exterioridade é de outra ordem. O outro sabe tudo sobre ele, ele é quase transparente e, portanto, não haveria interioridade. Ele não sabe o que é o segredo. (VERTZMAN, 2009, grifos nossos)

Uma das diferenças centrais entre vergonha e culpa diz respeito ao tipo de reparação que cada uma convoca: enquanto a culpa deve ser reparada e expiada, a primeira não consegue fazê-lo. Consideramos diferentes tipos de sublimações, as que partem da tentativa de reparação da vergonha e as que buscam reparar a culpa. Esta última estaria na origem de algumas sublimações que mantêm uma relação muito próxima entre o 
objeto perdido que deveria ser abandonado e o objeto que será recriado, reinvestido na sublimação $^{49}$, o que encontramos na poesia de Ana C.

O sentimento de vergonha é aterrador após o acesso melancólico. Na fase maníaca, a fusão do eu com o superego, a liberação da censura e da libido permitem ao Eu fazer coisas que antes estavam fora de sua possibilidade, estavam inibidas, mais que recalcadas. Dar-se a ver fazendo o que o superego proíbe, ser olhado sem os mecanismos de defesa usuais - a culpa, a tristeza, a inibição - potencializa o sentimento de vergonha, que parece não ter expiação. O sofrimento do eu, o seu esmagamento, é visível pela apatia e desespero que aparecem quando a fase maníaca passa. A profundidade da depressão pós-crise pode, muitas vezes, ser maior que o estado anterior que teria precipitado a defesa maníaca, um processo que se retroalimenta e aprisiona o sujeito que perde cada vez mais a capacidade de construir narrativas e dar sentido à vida. O adoecimento físico aparece como uma camuflagem dessa vergonha que irá se sobrepor à culpa inconsciente, a qual gera a necessidade de punição do eu pelo Superego. Nos trabalhos de Vertzman $(2009,2012)$ a noção de perdão aparece como tentativa de mitigar essa vergonha.

Pensamos que no melancólico existe uma dupla fonte de irrupção pulsional, tanto a que vem do próprio trabalho de desinvestimento do objeto como também da ferida deixada pelo objeto perdido. Cintra (2000, p.140) nos diz que:

A tendência do melancólico a cobrir-se com a sombra do objeto, a assumir esta sombra sobre si, é um exemplo claro de transformação de investimento em desinvestimento, uma vez que a sombra nada mais é que a face do objeto que virou as costas, que des-investiu o sujeito. Assumindo de um lado a sombra do objeto, e de outro, criando um Eu Ideal que concentra em si um brilho fálico e absoluto, o melancólico descaracteriza tanto a luz quanto o escuro, criando uma dissociação que destitui tanto a luz quanto a sombra, de seus poderes fecundantes.

A autora também nos ajuda a compreender um pouco mais o desinvestimento aos objetos presente na melancolia quando afirma que:

Este desinvestimento produz o sem-sentido, ao mesmo tempo que é preciso considerar que o desinvestimento nunca é uma simples retirada completa do investimento mas ocorre deixando "restos desorganizados do sentido perdido...é [um estado] persecutório e cheio de remorsos melancólicos. Este sem-sentido que pode ser vivido

\footnotetext{
${ }^{49}$ O que nos levará a fazer uso da compreensão kleiniana que entende a sublimação como um processo que está diretamente relacionada à necessidade de reparação.
} 
de uma forma passiva, e paradoxalmente, impassível ou ativa, caracteriza a experiência do 'buraco negro', e corresponde à vivência de ser amaldiçoado ou danado, para lá de toda a esperança, de ser um prisioneiro da perdição (CINTRA,2000, p.122).

Portanto, o trabalho do luto, ele mesmo, poderia ser contaminado pelo trabalho subreptício da pulsão de morte - o que nos remete à "pura cultura da pulsão de morte" encontrada no superego melancólico - superego reconhecidamente tirânico e sádico. Perguntamos uma vez mais, seria esse excesso mortífero o que comprometeria a constituição "plena" do eu e impediria o sujeito de se apropriar dos outros recursos oferecidos pelo ambiente? Veremos que segundo a interpretação de autores como Rosenberg e Lambotte, o eu do melancólico teria sido presa das pulsões de morte que não foram suficientemente neutralizadas por falta de uma energia erótica em quantidade suficiente. O ferimento narcísico não torna possível o represamento da libido que escoa pelo buraco vazio que aparece no lugar da imagem integrada do corpo que deveria ter sido oferecida pelo outro. É Lacan quem irá nos oferecer as ferramentas para pensar a função do olhar e do espelhamento na constituição subjetiva.

\subsection{A problemática especular}

A contribuição de Lacan (1949) sobre o estádio do espelho nos auxilia a pensar como se daria a formação do ego e a apropriação da identidade através do olhar que um terceiro oferece à criança. Segundo Lacan (1949, p.100), o estádio do espelho

\footnotetext{
é um drama cujo impulso interno precipita-se da insuficiência para a antecipação - e que fabrica para o sujeito, apanhado no engodo da identificação espacial, as fantasias que se sucedem desde uma imagem despedaçada do corpo até uma forma de sua totalidade que chamaremos de ortopédica - e para armadura enfim assumida de uma identidade alienante, que marcará com sua estrutura rígida todo o seu desenvolvimento mental.
}

Assim, a partir do olhar materno totalizante e de seu narcisismo, o ego do bebê começará a se formar. Contudo, o ego melancólico não teria encontrado no outro o suporte para o reconhecimento de si mesmo e seu lugar de existência. Incapaz "[...] de romper os laços que parecia ter tão fortemente instaurado, o melancólico não renunciou 
a um ideal tão selvagemente defendido e, em vez de deixá-lo esvanecer-se, devorou-o para conservá-lo para sempre" (LAMBOTTE, 2000, p.79). A relação com seu próprio corpo ficará comprometida, como explica Lambotte (2000, p.81)

\begin{abstract}
Dotado de um rosto que não reconhece e de um corpo aguçado pelo vazio, o melancólico dá a impressão de dissociar-se, como se sua intimidade obedecesse a forças estranhas e para ele permanecesse, por conseguinte, inacessível. Na marca do espelho, lugar das primeiras identificações estruturantes, indicados pelos paradoxos freudianos deixados sem resposta, foi ali, sem dúvida que o olhar do melancólico adquiriu definitivamente essa hebetude que o caracteriza, por falta de um outro olhar que, numa troca benevolente, lhe teria permitido tomar por sua a imagem à sua frente.
\end{abstract}

Como nos aponta a autora, o eu ideal desses pacientes está contaminado por uma verdade que aparece cedo demais, a verdade de que a relação com o Outro ${ }^{50}$ é um logro, um engano; o sujeito melancólico não caiu na ilusão vital da relação ao Outro que lhe teria atribuído uma identidade. Essa relação estará refletida na maneira como esse sujeito se relacionará com o mundo:

As queixas colocadas tais como: não vale a pena fazer o que quer que seja, já que não há sentido, não há verdade, etc., e que se justificam num primeiro nível a apatia melancólica, denunciam sem dúvida o efeito catastrófico do logro de que o sujeito foi vítima e pelo qual recusa agora se deixar tomar. Mais ainda, se esta recusa traduz, como vimos, o único modo de defesa que lhe foi possível elaborar, é de um verdadeiro traumatismo que se trataria para o melancólico, de um modo de reação estrutural ao qual ele não podia escapar, não mais que o podia modificar [...] (LAMBOTTE,1997,p.391).

Para Lambotte (1997), a especificidade do discurso melancólico está no ponto de definição dessa "estrutura", a qual acontece em um tempo pré-especular, antes da criança entrar na fase do espelho, ou melhor, no momento em que ela estava conquistando sua imagem e seu desejo. Segundo a autora, a mãe é responsável por investir com seu olhar a imagem da criança que iria identificar-se através desse espelhamento que a mãe faz. O melancólico padece de um abandono daquele objeto que ele já tinha percebido que estava 'por ali'. O que descrevemos aqui se assemelha ao que

${ }^{50}$ O "grande Outro" é a própria referência ao simbólico, uma noção "concebida como um espaço de significantes que o sujeito encontra desde seu ingresso no mundo [...]. O Outro vai se tornar mais especificamente o lugar 'onde se constitui o eu que fala'. [...] O movimento do desejo procede da articulação do sujeito com o Outro e do Outro com o sujeito, razão por que o lugar do Outro se encontra como lugar do único possível da verdade”. (KAUFMANN, 1996, pp.385-387) 
Green (1988) nomeou como a "Mãe Morta" 51 e ao que Lacan chamou de "suicídio do objeto" ${ }^{52}$. A criança percebe que seu objeto de investimento se tornou opaco e sem vida, é um morto, um nada que apareceu no lugar de onde vinha o cuidado e o afeto. O efeito é de uma verdadeira catástrofe narcísica, de uma ferida no eu que não sabe mais qual é o seu referencial. O pequeno sujeito irá então buscar mecanismos defensivos para não sucumbir à dilaceração de sua imagem corporal e à hemorragia libidinal que escoa pela ferida narcísica.

Lambotte (1997) nos diz ainda que não só o sujeito efetua uma identificação narcísica, mas o sujeito identifica-se com o nada que ficou no lugar do objeto de amor, identifica-se com o próprio movimento de partida do objeto. As auto-acusações e o discurso do "não ser nada" podem ser entendidas agora como título da identidade desses sujeitos que sabem, mais do que todos, sobre o logro da identificação necessário para a constituição da vida. Esses sujeitos não param de denunciar essa verdade que lhes apareceu cedo demais, que as relações estão fadadas, que a vida é só um jogo, e que a morte é mais próxima do que se imagina. O discurso niilista vem como um anteparo a esses sujeitos que buscam se proteger a todo tempo de uma nova catástrofe e, por isso, antecipam o término de suas relações e se mantêm mais afastados do mundo, embora o veja com uma lucidez mortífera.

O recurso que esses sujeitos possuem é o da negatividade, o de acreditarem que nada é para eles, que nada vale a pena, que as coisas não fazem sentido. A negatividade do melancólico muitas vezes é aproximada ao mecanismo descrito por Freud como (Verleugnung), o desmentido ou desautorização - típicos da perversão. O melancólico não deixa de perceber as diferenças na realidade (a diferença anatômica entre os sexos,

\footnotetext{
51 “A transformação na vida psíquica, no momento do luto súbito da mãe que desinveste brutalmente seu filho, é vivida por ele como uma catástrofe. Por outro a lado, porque sem nenhum aviso prévio o amor foi repentinamente perdido. $\mathrm{O}$ trauma narcisista que esta mudança representa não precisa ser longamente demonstrado. É preciso, no entanto, sublinhar que ele constitui uma desilusão antecipada e que provoca, além da perda de amor, uma perda de sentido, pois o bebê não dispõe de nenhuma explicação para dar conta do que aconteceu. É claro que considerando-se como centro do universo materno, ele interpreta essa decepção como a consequência de suas pulsões para com o objeto.[...] Depois da criança ter tentado uma vã reparação da mãe absorta por seu luto, que lhe fez sentir a medida de sua impotência, depois de ter vivido a perda do amor da mãe e a ameaça da perda da própria mãe e que lutou contra a angústia através de diversas maneiras ativas, entre elas a agitação, a insônia ou os terrores noturnos, o Eu vai pôr em ação uma série de defesas de outra natureza. A primeira e a mais importante será um movimento único com duas vertentes: o desinvestimento do objeto materno e a identificação inconsciente com a mãe morta". (GREEN, 1988, p.248 e 249)

${ }^{52}$ Essa ideia aparece no seminário sobre a transferência, onde lemos: "um remorso de um certo tipo, desencadeado por um desenlace que é da ordem do suicídio do objeto. Um remorso, portanto, a propósito de um objeto que entrou, de algum modo, no campo do desejo e que, por sua ação, ou por qualquer risco que correu na aventura, desapareceu" (LACAN, 1961/1992, p. 380).
} 
por exemplo), o mecanismo que ali reconhecemos assemelha-se ao "eu sei, mas, mesmo assim ...", que nos explica Mannoni (1973). O tipo de desmentido ou recusa que aparece no discurso melancólico é o de que as coisas do mundo existem, mas nenhuma delas lhe diz respeito.

\subsubsection{Dos mecanismos defensivos da melancolia}

A melancolia coloca em primeiro plano o Eu, esta instância que representa o sujeito e é responsável pela mediação entre seus conteúdos internos e a exigência da realidade externa. Dentre as maneiras que o melancólico encontra para lidar com sua particular composição subjetiva estão os mecanismos defensivos conhecidos como inibição, negativismo, a identificação ao nada, o masoquismo moral, a sexualização do pensamento, a mania - além, é claro, da identificação narcísica.

Vemos como o complexo melancólico aciona defesas que vêm em auxílio desse eu que se transformou e é o alvo de uma "pura cultura da pulsão de morte". A instância crítica que acusa o eu precisa ser calada, é necessário reinvestir nos objetos externos e liberar os canais de fluxo da libido. A chamada "virada maníaca", a qual muitas vezes acompanha a melancolia diz respeito a essa tentativa precária de sobrevivência do eu. $\mathrm{O}$ que encontramos na mania é o pólo oposto da melancolia, onde a realidade externa é superinvestida, todos os objetos do mundo externo (e interno) têm o potencial de se desdobrar em múltiplos sentidos e a energia dispensada ao eu para suas atividades parece ser ilimitada. As censuras são diminuídas, novos arranjos são experimentados, antigos ideais e projetos são retomados e reinvestidos. De acordo com Freud (1933 [1932], p.80): “o ego liberado, maníaco, permite-se uma satisfação verdadeiramente desinibida de todos os seus apetites. Aqui estão acontecimentos ricos em enigmas não solucionados". É interessante para nós o fato de que o mais importante trabalho de tradução de Ana Cristina César foi o poema de Katherine Mainsfield chamado "Bliss", palavra que se refere ao êxtase que dá o tom da mania.

$\mathrm{Na}$ crise melancólica vemos o supereu se tornar um complemento do eu totalmente distinto, tratando-o como puro objeto, enquanto na mania, de maneira inversa, encontramos uma fusão do eu com o supereu, que se tornam uma instância única; 
aparentemente é como se o supereu tivesse perdido a sua força ou estivesse fundido no eu. Com as palavras de Freud (1933 [1932], p.79-80),

(...) durante um surto melancólico seu supereu se torna super severo, insulta, humilha e maltrata o pobre eu, ameaça-o com os mais duros castigos, recrimina-o por atos do passado mais remoto, que haviam sido considerados, à época, insignificantes (...). O supereu aplica o mais rígido padrão de moral ao eu indefeso que lhe fica à mercê; (...) Em determinadas formas da doença (mania), na verdade, passa-se algo de tipo contrário, nos intervalos; o eu encontra-se em um estado beatífico de exaltação, celebra um triunfo, como se o supereu tivesse perdido toda a sua força ou estivesse fundido no eu (...).

O maníaco suspende os ataques ao objeto perdido que está identificado ao eu, entretanto, permanece sem o conhecimento do que foi levado na perda. Este conteúdo inconsciente permanece tanto na mania quanto na melancolia. Não poder saber o que foi perdido - uma vez que o que se perdeu (o eu, "a coisa") não pode ser representado por ter ocorrido num tempo onde a linguagem ainda não existia e a separação do eu ainda não havia se concluído - serviria ainda de estímulo para a fuga de ideias que aparecem e aceleram o pensamento e que podem chegar a construções delirantes. Deriva também daí a confusão nosográfica que localiza a melancolia como psicose, uma vez que o delírio pode ser interpretado como o fator distintivo definitivo da recusa da realidade. No entanto, Lambotte (1997) nos lembra que antes de uma negação da realidade, da não aceitação da castração, o melancólico é aquele que foi castrado desde o início, estando muito mais próximo da realidade que a simples neurose. A mania expressa justamente a tentativa de se reencontrar com a verdade que ele já descobriu precocemente. Através do delírio o sujeito cria novamente para si as condições de separação precária entre o mundo externo e interno, entre o que está delimitado pelo seu corpo e o que pertence ao mundo externo. O indivíduo pode experimentar a onipotência de pensamentos, elemento fundamental na sua constituição que foi frustrado, ele é - talvez pela primeira vez - o centro do mundo. Essa megalomania se opõe às tendências persecutórias do eu e a euforia garante que o sentimento de exceção não seja o de ser o excluído, o culpado, o que precisa de expiação.

Como vimos anteriormente, um dos fenômenos observados na clínica dos pacientes melancólicos é a auto-recriminação ${ }^{53}$ melancólica que nos traz aspectos que

\footnotetext{
${ }^{53}$ Pensamos que a auto-recriminação, a auto-depreciação característica da melancolia pode adquirir várias "máscaras". Poderíamos reconhecer uma auto-depreciação nos sujeitos que anulam o seu desejo, seja porque acreditam que o seu desejo é mortífero para os outros ou porque não acreditam ser possível haver
} 
reconhecemos no "masoquismo moral". Rosenfeld (2003) nos fala como o masoquismo seria uma tentativa do sujeito suportar uma culpa que é insuportável. O desprazer incomensurável produzidos pelo sentimento de culpa inconsciente deverá ser sexualizado, e, assim, através da inversão do desprazer em prazer masoquista, o sujeito se protegeria contra o colapso psíquico. Esse masoquismo moral incluirá e dará um destino, funesto, para as vozes do que foi chamado por Figueiredo (2012) de "Supraeu", isto é, a dimensão mais arcaica do psiquismo.

Um dos sintomas necessários da melancolia é a anestesia psíquica. A mencionada anestesia pode ser traduzida em uma fala que é recorrente entre os pacientes melancólicos: "Não vale a pena fazer isto ou aquilo, afinal, nada tem importância". De acordo com Cintra (2000, p.44):

[...] pode-se afirmar que o ferimento narcísico polarizou para si próprio toda a energia psíquica possível, na tentativa de elaborar a dolorosa perda de valor, mas este luto parece não poder se cumprir: a certeza imaginária da interrupção do contato afetivo, da instalação iminente do desamparo é tão grande que é preciso encená-la imediatamente, para abreviar a angustiante espera. É preciso convocar o estado gelado para reduzir a dor de esperá-lo. Não há possibilidade de substituir a relação afetiva atual por outra, em que haja fluxo de amor.

A anestesia psíquica nos mostra como o sujeito melancólico se defende do sofrimento provocado pela necessidade de lidar com o que vem do mundo externo e do mundo interno - "o perigo de vida", de voltar a perder algo que já foi perdido, mas não se sabe. A perda de um vínculo tão precoce é sentida como uma morte e o medo de um novo arrombamento faz com que o sujeito se mantenha a todo tempo em posição defensiva de espera por essa verdadeira catástrofe que ele acredita estar fadada a acontecer novamente. É como se não fosse possível cicatrizar-se, e a inibição, o congelamento, a desafetação aparecem para minimizar a dor. Nas palavras de Freud (1917[1915]/2010, p.175)

Mas a inibição melancólica nos parece algo enigmático, pois não conseguimos ver o que tanto absorve o doente. O melancólico ainda nos apresenta uma coisa que falta no luto: um extraordinário rebaixamento da autoestima, um enorme empobrecimento do Eu. No luto, é o mundo que se torna pobre e vazio; na melancolia, é o próprio $\mathrm{Eu}$.

algo que valha a pena (no que escutamos por trás, será que o sujeito não merece nada, ou só merece o nada?). Talvez não tenhamos que nos ater nas auto-depreciações literais do sujeito, cuja caricatura seria o auto-flagelamento. 
Como a escolha de objeto do melancólico é aquela do tipo narcísico, esse outro escolhido (como em uma neurose de destino) estará sempre em uma posição que o ameaça, uma vez que o sujeito depende do espelhamento nele para se reconhecer. A experiência vivida é a de um exílio, onde a aproximação afetiva é uma ameaça e o distanciamento alimenta a inibição e o estado de congelamento produzido para evitar a dor. Abraham (1970, p.42) nos diz que a

inibição mental parece ser o primeiro sintoma a se manifestar. [...] Refiro-me particularmente à tendência de 'negação da vida'. Os graus mais altos de inibição, especialmente - isto é, o estupor depressivo representam uma morte simbólica. $\mathrm{O}$ paciente, exatamente como se não estivesse mais vivo, não reage mesmo à aplicação de fortes estímulos externos.

A "paisagem psíquica" do melancólico é de agressividade e concretude, sem cor. A inibição característica do melancólico já aparecia nas figuras da melancolia na antiguidade - inibição que se assemelha à preguiça e poderia ser traduzida nos termos medievais conhecidos como acídia e tristitia . Como já não o era naquele tempo, essa "preguiça" não deveria ser tratada como um pecado capital ou uma falta moral. Ela seria antes, o efeito de uma paralisação frente a um ideal impossível, ela ilustra o medo de que o chão desapareça debaixo dos pés ao se mover. O filósofo Agamben (2007, p.30), para pensar a relação do fazer humano na cultura ocidental, recorre ao conceito de melancolia, desde sua apropriação pela igreja católica até Freud. Para ele. "a preguiça é uma consequência da acídia e não sua essência. Na clássica figuração da Melencolia de Dürer, o gesto de deixar cair a cabeça sobre uma mão está significando o desespero e não o sono". Agamben (2007, p.32) também ressalta tanto a relação com o gênio quanto a dimensão inalcançável do ideal:

Ao mesmo tempo em que a sua tortuosa intenção abre espaço à epifania do inapreensível, o acidioso dá testemunho da obscura sabedoria segundo a qual só a quem já não tem esperança foi dada a esperança, e só quem, de qualquer maneira, não poderá alcançá-las foram dadas metas a alcançar. Tão dialética é a natureza do seu "demônio do meridiano": assim como se pode dizer da doença mortal, que traz em si a possibilidade da própria cura, também daquela se pode afirmar que a maior desgraça é nunca tê-la tido". 
A paralisia e a imobilidade estariam referidas à certeza da inadequação de qualquer ação sua, da impossibilidade de atender às exigências erigidas - sendo estes, motivos adicionais para mais castigos superegóicos. De acordo com Lambotte (1997, p.392):

De fato, parece que para o sujeito melancólico a que nos prendemos até o momento, e atrás do qual se perfila a estrutura específica que tentamos esclarecer, não se trata de ultrapassar a ilusão da intersubjetividade, nem de preferir desaparecer a confrontar-se com ela, mas de se defender contra o logro da intersubjetividade no sentido do engano e, em consequência, de rechaçar todo investimento afirmando que ele está trucado antecipadamente ${ }^{54}$.

Um modo de defesa próprio do sujeito melancólico chamado comumente de negativismo, será utilizado de uma forma original na melancolia: é mister apontar que este não se trata do mesmo processo encontrado na psicose e na esquizofrenia. $\mathrm{O}$ mundo melancólico é desencantado, desafetivizado, sem esperança, onde se torna difícil ser surpreendido com a trivialidade das coisas que poderiam ser tomadas como belas. Como vimos, o melancólico não irá desconsiderar que os outros existem, que a vida pode ser prazerosa e possuir sentido, por outro lado, o que vemos nessa figura melancólica é a impossibilidade do melancólico de sentir que aquilo que será encontrado na realidade externa diga respeito a ele. Sobre este ponto, pensamos que este tipo de defesa poderia funcionar como uma formação reativa a um primeiro momento em que o sujeito acreditou, onipotentemente, que seria ele quem teria provocado a destruição do objeto. Ao mesmo tempo, vemos que este tipo de negação refere-se à fragilidade do suporte externo que por algum motivo não teria sido capaz de metabolizar os elementos destrutivos e devolvê-los de forma mais integrada. Lambotte (1997, p.21) irá definir onde se posiciona a recusa do melancólico:

Entre o recalque e a foraclusão, o tipo de recusa que o sujeito melancólico opõe à realidade encontrará talvez sua expressão no desmentido, termo que, sem negar a existência da coisa, nega entretanto, que ela diga respeito no que quer que seja ao sujeito. E atrás da negação se perfila a alternativa melancólica no que esta deve ao ideal ou à morte, ou seja, ao tudo ou ao nada da desaparição do outro que o sujeito assume sob a figura da falta. Não resta mais que encerrar um tal desenvolvimento, na medida em que o sujeito ignora que continua a viver os efeitos de uma catástrofe à qual não se podem

\footnotetext{
${ }^{54} \mathrm{~A}$ diferença entre a ilusão e o logro "está notadamente no engano, pela palavra ou pelo gesto, de uma sedução que consiste em dar ao falso a aparência do verdadeiro. O logro é desta ordem. Da mesma forma, o sujeito melancólico não pára de denunciar o logro e, em primeiro lugar, o logro da identidade na medida em que ele "sabe" a ilusão da relação ao Outro". (LAMBOTTE, 1997, p.392)
} 
aplicar as categorias da linguagem, e a referência ao destino substitui desde então a experiência do real, na conviç̧ão de deter a verdade: a da morte.

Assim, podemos imaginar que a interação do melancólico com o outro estará comprometida com essa dimensão do "desmentido". A possibilidade de uma relação com o outro será desmentida, uma vez que o outro primordial imprimiu a marca da ausência (ou do excesso) que não permitiu ao ego melancólico criar seu contorno e se ver como uma unidade capaz de receber investimentos do mundo externo. Perguntamos com Lambotte (1997. p. 391) :

Ora, não seria precisamente a concepção do sujeito melancólico não poder encarar as relações sociais senão a título da exclusão que viria responder ao inevitável mal-entendido sobre o qual elas repousam?

A melancolia é um estado no qual o sujeito se vê distante de suas relações com o mundo e com os outros. Nela, a solidão é símbolo das pulsões de morte, as quais procuram desfazer todos os elos, a representação que se constrói para atribuir um novo sentido à vida (cujo objetivo é desligar toda a energia que estava ligada) e retirar dos objetos o investimento garantidor de vínculo. A agressividade que não pôde ser externalizada se volta contra o eu e funciona também como um agente de ataque às construções representacionais. A ausência de sentido também poderia ser um efeito dessa desconstrução promovida pela agressividade, movimento que, ao acionar a pulsão de vida para conter a destruição do eu, acaba sexualizando o próprio não sentido e a dor que acompanha o desinvestimento - a do trabalho de luto, por exemplo, acabaria se tornando masoquismo moral. O suicídio aparece como mais uma tentativa de contenção da dor que se assoma ao eu. Paradoxalmente, ele também é uma tentativa do sujeito escapar de sua dor. De acordo com Lambotte (1997, p.374):

Mais agressividade voltada contra si, o suicida exige, sem dúvida a energia especifica da passagem ao ato que dá a esta última sua significação. Adiantamos anteriormente, a propósito da defenestração melancólica, o impulso do sujeito de juntar-se ao nada suposto subsistir atrás das coisas como um testemunho de sua verdade recoberta e, consequentemente inacessível; e é numa verdadeira identificação imaginária ao nada que o sujeito atravessa a moldura vazia para enfim apoderar-se da verdade que ele sabia desde sempre.

O suicídio seria o último recurso do sujeito para finalmente conseguir uma representação do nada ao qual se identificou. A morte derradeira seria o destino trágico 
para o "suicídio do objeto", uma última tentativa de representação daquilo que foi vivido na primeira infância. Encontramos raciocínio semelhante também em Ferenczi $(1934 / 2011, \text { p.127, grifos do autor })^{55}$ :

O desprazer cresce e exige uma válvula de escape. Tal possibilidade é oferecida pela autodestruição, a qual, enquanto fator que liberta da angústia, será preferida ao sofrimento do mundo. $\mathrm{O}$ mais fácil de destruir em nós é a consciência, a coesão das formações psíquicas numa entidade: é assim que nasce a desorientação psíquica. (A unidade corporal não obedece tão prontamente ao princípio de autodestruição).

No melancólico, a oposição sistemática previne o risco da decepção que este sujeito sabe - com horror - não poder dominar novamente. Distanciar-se do mundo e de si seria uma possibilidade do melancólico escapar à morte real pelo suicídio, morte esta que significaria o fim de uma "lógica da evidência" (Cf: LAMBOTTE, 1997, p. 362). A análise em primeira pessoa que Kristeva (1989) faz do que ela chamou de "sol negro", ilustra o que disseram os autores supracitados. Nas palavras da autora, "brotadas da melancolia":

Em suma, uma existência desvitalizada que, embora às vezes exaltada pelo esforço que faço para continuá-la, a cada instante está prestes a oscilar para a morte. Morte vingança ou morte liberação, doravante ela é o limite interno do meu abatimento, o sentido impossível dessa vida, cujo fardo, da cada instante, me parece insustentável, salvo nos momentos em que me mobilizo para enfrentar o desastre. Vivo uma morte viva, carne cortada, sangrante, tornada cadáver, ritmo diminuído ou suspenso, tempo apagado ou dilatado, incorporado na aflição... Ausente do sentido dos outros, estrangeira, acidental à felicidade ingênua, eu tenho de minha depressão uma lucidez suprema, metafísica. Nas fronteiras da vida e da morte, às vezes tenho o sentimento orgulhoso de ser a testemunha da insensatez do Ser, de revelar o absurdo dos laços e dos seres. (KRISTEVA,1989,p.12)

Deste modo, vemos que a tentativa de nomeação da experiência catastrófica acontece com parcos recursos, uma vez que a prematuração psíquica não permite uma rede representacional que contemple o traumatismo da experiência (com o outro). Talvez, o

\footnotetext{
${ }^{55}$ Kupermann em seu artigo "A progressão traumática" (2006) nos esclarece um pouco mais sobre a leitura ferencziana: "Em "Reflexões sobre o trauma", Ferenczi ilustra a clivagem psíquica como a reação do "homem abandonado pelos deuses", que "escapa totalmente à realidade e cria para si um outro mundo no qual, liberto da gravidade terrestre, pode alcançar tudo o que quiser" . Cria-se, dessa maneira, um anjo da guarda desencarnado que virá em socorro do sujeito traumatizado pelo isolamento a que se viu submetido. Porém, no limite, essa saída poderá conduzir ao suicídio, já que anjos da guarda tendem a se mostrar, mais cedo ou mais tarde, impotentes.
} 
que Ferenczi observou como o efeito nocivo de um amadurecimento precoce, não esteja distante do que estamos descrevendo: um desvio na rota do desenvolvimento psíquico da criança que teve que tornar-se sábia para cuidar de si e da mãe que não dispõe de recurso psíquico para a maternagem. Sobre essa verdade que o melancólico chega perto demais, Kupermann (2008, p.153) nos lembra com Ferenczi que:

A aquisição precoce de um saber e de uma maturidade própria dos adultos cobra, portanto, um preço alto, o da insensibilidade como comprometimento da capacidade de afetar e de ser afetado pelo outro, que se faz acompanhar pela impossibilidade de expressão dos afetos de amor e de ódio e por uma consequente diminuição da potência para se afirmar de modo singular e, no limite, também da vontade de viver.

Observamos aqui como em um primeiro momento o conhecimento da verdade produz um amadurecimento, que colocará em risco a vida do sujeito. As consequências dessa precocidade serão devastadoras. A criança que entra em sofrimento com seu desamparo e não é acolhida a tempo acaba por perder a esperança de que algum dia o objeto de amor voltará. De acordo com Vertzman (2002), uma das consequências mais notáveis do trauma é a dissolução das correlações anteriores entre o eu e o que podemos denominar de vida sentimental:

A pessoa divide-se num ser psíquico de puro saber que observa os eventos a partir de fora, e num corpo totalmente insensível. Na medida em que o ser psíquico ainda é acessível aos sentimentos, incide todo o seu interesse no único sentimento que subsiste de todo o processo, isto é, o que o agressor sente. (FERENCZI, 1990, p. 142).

A problemática que estamos descrevendo nos permite pensar que a relação entre a escritora Ana C. e sua obra traz a marca dessa divisão.

Na melancolia observa-se que o estilhaçamento do eu ideal faz com que sujeito forme um ideal todo-potente, impossível, em relação ao qual estará sempre em defasagem, em déficit, oferecendo-se submissamente aos ataques do superego, das vozes que o acusam, que o humilham e massacram. Ferenczi (1990, p. 143) nos diz que,

Considerado de um outro ponto de vista, o da indestrutível pulsão de auto-conservação, o mesmo processo deveria ser descrito desta maneira: quando se abandonou qualquer esperança de ajuda por parte de uma terceira pessoa, e sente-se as próprias forças de autodefesa totalmente esgotadas, nada mais resta senão esperar pela clemência do agressor. Se me submeto tão completamente à vontade dele que deixo 
de existir, se, portanto, não me oponho a ele, talvez me conceda salvar a própria vida...

Como dissemos, a formação do ego implica em um abandono do objeto de amor. Esse passa a se tornar parte do ego, isto é, uma dessexualização já está presente neste momento. A energia que é retirada dos objetos é investida no ego, fica represada narcisicamente. Os passos seguintes para a formação de um sujeito são, de certo modo, reedições desse desinvestimento para um posterior investimento. No ego melancólico, algo aconteceu nesse processo, sendo possível, a posteriori, observar a patologia narcísica que se desenvolve. Acreditamos que a desfusão pulsional, desde a origem da constituição do sujeito psíquico, tem um papel nessa composição especial de subjetividade, em que a pulsão de morte ficaria mais "resistente" às possíveis investidas da pulsão de vida. A "identificação ao nada" que encontramos na melancolia, como descreve Lambotte (1997, p.374), pode ter sido precipitada por essa desfusão pulsional. Por que não foi possível ao sujeito melancólico nenhum outro tipo de identificação que desse o suporte a um ideal que o sustentasse? Seguimos a indicação da autora:

[...] para o que concerne ao sujeito melancólico, nos poderíamos perguntar se esta colocação à parte da comunidade que ele se empenha em justificar racionalmente, e que se apoia numa desapropriação dos afetos e do desejo na origem de sua relação ao outro, não foi a causa de uma intrincação insuficiente dos dois tipos de pulsões, intrincação na qual a pulsão de morte conservaria ainda uma grande autonomia. E na medida em que os dois tipos de pulsão são indiscerníveis no início da formação do aparelho psíquico, poderíamos pensar que a pulsão de morte insuficientemente ligada, por um lado, e na impossibilidade de ser projetada para o exterior, por outro lado, tenha colocado a pulsão de vida a serviço da auto-destruição no prazer repetitivo da erotização. (LAMBOTTE, 1997, p. 315)

Nas observações feitas até o presente momento, constatamos como a construção do ego implica uma "sublimação da pulsão" que estava investida nos primeiros objetos de amor. Encontramos nos sujeitos melancólicos uma relação patológica com seus objetos de amor perdidos e uma relação particular com os ideais identificatórios. A clínica da melancolia irá nos mostrar que a especificidade do discurso melancólico implica outros modos de aproximação do analista.

Se tomarmos, entretanto, a noção de resistência em sua vertente positiva como indicadora do nosso caminho, podemos supor que o objetivo destes sujeitos é fazer da nossa presença o testemunho ocular 
de uma verdade que se esconde na aparente uniformidade de seus relatórios diários. Eles usam o olhar do analista como garantia de que suas ações, sensações e sentimentos formam conjuntos que podem ser reconhecidos como sendo suas vidas. Este reconhecimento que, para muitos, é imediato e pré-reflexivo, só ocorre, quando ocorre, após muito labor. Aquilo que é o ponto de partida de muitos percursos analíticos e que deve ser desconstruído para que ele se dê, não o é em absoluto para estas pessoas. Um sentimento de estranheza radical em relação a si as invade. $\mathrm{O}$ vazio que as acomete parece localizar-se na própria ideia de ser, o que acarreta numa falta de consistência da imagem narcísica e numa percepção de futilidade e indiferença quanto às próprias ações. (VERTZMAN, 2002, p.60)

Tanto a clínica do luto quanto a própria concepção de trabalho de luto parecem não nos oferecer todas as ferramentas para pensarmos o problema da melancolia. A ideia de um "trabalho de melancolia" nos é cara ao empreendermos a busca de uma compreensão mais específica do problema. Sob os auspícios dos teóricos anteriormente mencionados iremos, a seguir, buscar em Rosenberg (2003) noções que iluminarão os aspectos obscuros que fazem parte da constelação de causas e efeitos da melancolia.

\section{$2.4 O$ trabalho de melancolia}

Por encontrarmos muita afinidade entre nosso raciocínio e o trabalho desenvolvido por Rosenberg (2003), iremos desenvolver aqui seu argumento sobre a diferença entre o trabalho de luto e o "trabalho de melancolia" a fim de avançarmos em nossa investigação. O "trabalho de melancolia", o de luto e, também o da sublimação possuem nuances que devem ser consideradas na investigação de nosso tema. Indicamos aqui o que parece estar na centralidade de nossa discussão:

o sucesso do trabalho de melancolia repousa na possibilidade da passagem do sadismo desintrincado pulsionamente do melancólico ao masoquismo, um processo equivalente a uma reintrincação pulsional. Tudo isso introduz a questão mais geral das relações entre melancolia e masoquismo que é preciso rever do ponto de vista do trabalho da melancolia. (ROSENBERG,2003, p.153)

Enquanto no luto normal a "destacabilidade" do objeto está assegurada, na melancolia o trabalho do luto complica-se. Somos levados a pensar que para ser possível o desapego ao objeto é necessário um outro tipo de trabalho - o trabalho de 
melancolia. Iremos definir assim a diferença entre o trabalho de luto e o trabalho de melancolia: no primeiro, trata-se de realizar o desapego do objeto perdido enquanto no trabalho de melancolia deve-se, antes que o desapego seja possível, assegurar a mencionada "destacabilidade do objeto". O trabalho de melancolia será definido então como "o trabalho psíquico elaborativo da "não-destacabilidade". Este trabalho tem como objetivo liquidar o investimento narcisista do objeto.

A não-destacabilidade, por sua vez, está ligada ao investimento narcisista de objeto e "torna-se praticamente a predisposição à melancolia, já que, é ela que torna impossível o trabalho do luto" (ROSENBERG, 2003, p. 129). É a escolha de objeto do tipo narcisista que irá precipitar a identificação narcísica - movimento que tenta garantir a presença do objeto dentro de si. Tal "destacabilidade do objeto" está relacionada com a possibilidade de uma desidentificação.

O trabalho de melancolia compreende, então: uma elaboração da destacabilidade antes que o desapego do objeto seja possível; uma tentativa de liquidar o investimento narcisista de objeto ao menos à medida que permitirá um deslocamento sobre outro objeto, mesmo que esse último seja sempre investido de modo narcisista; uma tentativa de ligar a raiva do objeto, cujo aumento provocou o acesso melancólico.

Sobre a relação entre a escolha narcisista, a qual fundaria a não-destacabilidade do objeto, o autor diz:

Investir narcisisticamente um objeto é investir-se a si mesmo por meio do objeto, ou, se preferirmos, investir-se a si mesmo no espelho do objeto. Se isso é verdade, desinvestir o objeto quer dizer de fato desinvestir-se a si mesmo: aceitar que o objeto está perdido é perderse a si mesmo. A melancolia experimenta a perda do objeto como uma perda de si, como um desinvestimento narcisista de si. (ROSENBERG, 2003, p.129)

Observamos que, para além das considerações sobre a ambivalência e a raiva contidas na melancolia ou voltar-nos para o sadismo melancólico, a questão fundamental que o trabalho de melancolia deve resolver é aquela da desintrincação. De acordo com o autor, o problema fundamental com o qual nos deparamos na melancolia é a desfusão pulsional extrema. O sucesso ou o fracasso do trabalho de melancolia estaria condicionado ao fato de Eros conseguir ou não ligar a pulsão de destruição, de se conseguir um nível de reintrincação pulsional que seja suficientemente bom para que o acesso de melancolia se interrompa. O trabalho de melancolia seria bem sucedido no 
momento em o sadismo desintrincado pulsionalmente passaria ao masoquismo, o que seria o equivalente a um processo de reintrincação pulsional (CF: ROSENBERG, 2003, pp. 151-153). Acompanhamos a hipótese do autor:

o trabalho de melancolia pode resultar no reinvestimento de um (novo) objeto(externo), de uma outra pessoa, contanto que a introjeção evolua e se transforme em identificação, e que assim, a culpa com relação ao objeto perdido seja vivida. ${ }^{56}$ As duas coisas estão ligadas. Aliás, sabemos, e Freud não deixou de observar que é a culpa que transforma o sadismo em masoquismo. (ROSENBERG, 2003,p.147)

O acesso de melancolia seria uma crise que tem início com um aumento notável da raiva e do sadismo antes escamoteados pelo investimento "narcisista-idealizante" do objeto depois da perda do objeto amoroso. Ora, se como vimos, a sublimação depende de uma força agressiva, de uma destrutividade para ocorrer, pensamos que este aumento da raiva e do sadismo melancólico possa sofrer também a interferência do processo sublimatório em si.

De acordo com Rosenberg (2003), através da introjeção-identificação o eu é convocado a usar sua própria libido, sendo que ele irá, ao mesmo tempo, - ao se oferecer como objeto de amor ao isso - receber um aporte libidinal maior por parte deste último. O que, em última instância, decidiria o êxito ou a falha do trabalho de melancolia é a balança econômica entre o que se ganha e o que se perde. O problema é que, a libido a mais que vem do id pode servir para aumentar a força do superego, aumentando seu sadismo contra o eu - lembramos que o supereu tem suas raízes no id, o que complica ainda mais a dinâmica. Ademais, o eu, estando identificado à parte má do objeto, gasta ou perde esta energia com seu próprio masoquismo; e ainda, o eu, ao ser objeto de investimento de satisfação do id, tem que se submeter a ele, tentando atender a suas exigências de satisfação imediata, gastando novamente energia para construir defesas contra esse novo vínculo. Desse modo,

Para resultar nessa ligação da destrutividade, na reintrincação pulsional, o eu utiliza sua própria libido narcisista ${ }^{57}$ e compreendemos

\footnotetext{
${ }^{56} \mathrm{~A}$ “introjeção: parece-nos ser um processo correlativo à projeção que faz com que o eu abrigue em si mesmo aquilo que foi introjetado e que pode ser a qualquer momento reprojetado sem que o eu seja, ele próprio, profundamente modificado por isso. [...] A identificação é apenas um introjeto abrigado no eu; ela é uma transformação, uma remodelagem do próprio eu a partir do modelo do objeto.[...] sendo que essa remodelagem do próprio eu pode se tornar, em alguns casos, um traço de caráter definitivo do eu". (ROSENBERG, 2003, p.146)

57 Pensamos aqui numa ferida que é reaberta incessantemente e que solicita um contra-investimento extraordinariamente elevado. "O complexo da melancolia se comporta como uma ferida aberta, de todos
} 
melhor o papel da introjeção-identificação quando pensamos que por meio dela é o próprio eu que é atacado, o que lhe representa uma solução indubitável para investir sua libido narcisista na ligação da destrutividade que é depositada nele. Essa dissipação de libido narcisista representa um grande perigo para o eu, podendo esgotar-se com a tarefa, esvaziar-se de sua libido narcisista e assim sentir-se ele mesmo tão desvalorizado (e culpado) que o suicídio torna-se a última solução que lhe resta. (ROSENBERG, 2003, p.151)

Entendemos então que a reintrincação pulsional distingue o trabalho de melancolia, que busca fazer a passagem do auto-sadismo para o masoquismo. Esse ponto é fundamental: "a ligação pela libido da pulsão de morte é a definição que Freud dá ao masoquismo erógeno primário e sabemos que o masoquismo erógeno ${ }^{58}$, sendo uma das formas do masoquismo, é ao mesmo tempo a essência de todas as outras formas" (ROSENBERG, 2003, p.153). Se Freud afirmou várias vezes a existência da intrincação e a utilizou abundantemente para a reinterpretação pulsional dos fenômenos basais como a ambivalência, a regressão, a identificação, e certamente, o sadismo e o masoquismo, ele não descreveu o processo da ligação das duas pulsões. Sobre esse ponto, Freud (1923, p.158) nos diz:

Reconhecemos duas pulsões fundamentais e deixamos a cada uma o seu próprio objetivo. Saber como as duas se misturam no processo de vida, como a pulsão de morte é colocada a serviço das intenções do Eros, sobretudo quando a pulsão se volta para o exterior como agressão, eis aqui tarefas que estão reservadas à pesquisa futura. Não iremos além do ponto onde uma tal perspectiva se abre para nós.

A relação entre a reintrincação pulsional, ou a refusão pulsional, nos leva então aos primeiros momentos da constituição subjetiva. Acreditamos que a distensão do tempo produzida por uma necessidade que não foi atendida e deixou o pequeno sujeito no desamparo, chegando a produzir nele um sentimento de desesperança, deixaria um traço marcante sobre o qual encontraremos um trilhamento mais profundo que aquele

os lados atrai energias de investimento (que chamamos de "contra - investimentos" no caso das neuroses de transferência) e esvazia o Eu até o completo empobrecimento; com facilidade pode se mostrar resistente ao desejo de dormir do Eu. Um fator provavelmente somático, que não se explica de forma psicogênica, apresenta-se na atenuação que costuma ocorrer nesse estado depois que anoitece. Ligada a essas observações está a questão de se não bastaria uma perda no Eu, sem consideração do objeto, para produzir o quadro da melancolia, e se um empobrecimento tóxico direto da libido do Eu não poderia resultar em certas formas de doença. (FREUD,1915[1917/2010, p.186)

${ }^{58}$ Freud em "O problema econômico do masoquismo" (1924) nos diz que a pulsão de morte é em grande parte emanada para o exterior, mas uma outra parte não participa do deslocamento para o exterior, é nela que devemos reconhecer o masoquismo erógeno. 
produzido pelas marcas de experiências satisfatórias. Essa dimensão que será explorada mais a frente. A pulsão de morte terá mais território do que a de vida, uma vez que o masoquismo de vida teria tido que intervir numa proporção diferente àquela que veríamos em outros tipos de constituição subjetiva. A desfusão pulsional marca, desde o início, esse psiquismo, fazendo com que as ligações se tornem mais fracas e o medo da perda iminente. A pulsão de morte, que não se transformou em grito e choro - não tinha esperança suficiente para emitir o chamado -, foi silenciada, habitando para sempre um núcleo de desespero calado que pode, a qualquer momento, ser revivido. O paradoxo tal qual destaca Rosenberg (2003, p.188) é que, "quanto mais a pulsão de vida é gasta defensivamente em um esforço de auto-conservação, mais diminui ou esgota-se sua capacidade de alimentar um movimento progressivo-expansivo, que é o único que pode conservar, a longo prazo, a vida".

Não há uma intrincação nem desintrincação absolutas e não se trataria de uma mistura que transformaria as pulsões em uma só. Sabemos que é a possibilidade de desintrincação que garante a continuidade da vida, a diversidade e a variedade. Freud (1940[1938],p.174) nos diz que esse acordo e esse antagonismo das duas pulsões fundamentais conferem justamente aos fenômenos da vida toda a diversidade que lhes é própria. O interessante é que a intrincação pulsional sem intermédio do objeto é impossível: "uma união-fusão direta das próprias pulsões é incompatível com sua heterogeneidade. Seu antagonismo, aliás, só pode ser revelado no terreno do objeto". (ROSENBERG, 2003, p.161) De acordo com o autor, é em um terceiro terreno de encontro - com exceção do masoquismo erógeno primário, da problemática do narcisismo primário e da constituição do eu primário - que a libido tem como tarefa tornar inofensiva a pulsão de morte.

Abraham (1911/1970, p.41), mesmo sem possuir o conceito de narcisismo, nos oferece uma sofisticada explicação do fenômeno:

Em resultado da repressão do sadismo, surgem a depressão, a ansiedade e a auto-acusação. Contudo, se for obstruída uma fonte tão importante de prazer, da qual fluem os instintos ativos, tem de haver um reforço das tendências masoquistas. O paciente adotará uma atitude passiva e obterá prazer em seu sofrimento e em pensar continuamente sobre si próprio. Desta maneira, mesmo o mais profundo sofrimento de melancolia contém uma fonte oculta de prazer. 
De um lado temos o conflito ambivalente e a identificação narcísica, do outro, a raiva e o sadismo. Rosenberg (2003) localiza na raiva a evidência das fontes primárias da estrutura melancólica. A raiva é erotizada - ligada por investimento libidinal narcisista - e vivenciada sobre a forma de sadismo. Segundo ele, a ambivalência do melancólico seria de uma qualidade diferente daquela habitual nos neuróticos e mesmo no obsessivo. A "formidável raiva" do melancólico pelo objeto seria uma herança e um vestígio da agressividade implicada na constituição do objeto primário - o que nos mostra novamente a relevância das contribuições kleinianas acerca da posição depressiva, que apresentaremos no próximo item. É característica da melancolia a compensação dessa raiva destruidora do objeto pelo investimento narcisista -idealizador do mesmo. A predisposição à melancolia seria constituída, então, não somente por tal investimento, mas também "por um conjunto constituído pela raiva ao objeto e pelo investimento narcisista de objeto" ${ }^{59}$ (ROSENBERG, 2003, p. 143). Assim, nos diz o autor,

realiza-se no acesso melancólico o que podemos chamar de imperativo categórico do melancólico, imperativo que sempre fundou sua organização psíquica e que se afirma novamente: Não odiarás nem destruirás o objeto, porque com ele destruirás a ti mesmo! (ROSENBERG, 2003, p. 143)

A partir de Rosenberg (2003), compreendemos que, no trabalho do luto a via do inconsciente ao pré-consciente não está obstruída enquanto que no trabalho de melancolia o pré-consciente está como que apartado. Ao passo que trabalho do luto é possível alcançar o desapego do objeto através dessa integração entre préconsciente/consciente, o trabalho de melancolia "é obrigado a passar por uma outra via para eliminar essa barreira que impede o conflito de se integrar no pré-consciente[...] utilizando vias que lhe são particulares e características” (ROSENBERG, 2003, p. 128, grifos do autor). Nos lembramos que a sublimação não passa pelo recalque e é estimulada pelo ideal. Retomamos a discussão tópica com Freud:

Portanto, na melancolia trava-se inúmeras batalhas em torno do objeto, nos quais ódio e amor lutam entre si, um para desligar a libido

\footnotetext{
${ }^{59}$ É interessante a proposta do autor sobre o investimento homossexual ser uma proteção, uma defesa contra a melancolia: "A comunidade do tipo de investimento narcisista entre homossexuais e os melancólicos faz com que a homossexualidade possa representar uma defesa contra a melancolia. Mas ela pode representar mais do que isso: parece-nos que faz parte do tratamento do melancólico que a homossexualidade (manifesta ou não) possa representar o eixo pelo qual podemos fazer evoluir o tipo de investimento narcisista para um investimento objetal propriamente dito. A homossexualidade sendo, na análise, uma das vias reais da regressão ao investimento de objeto ao narcisismo, ela pode também ser a via de "retorno", a via de objetificação do tipo de investimento. (ROSENBERG, 2003, p. 132)
} 
do objeto, o outro, para manter essa posição da libido contra o ataque. Não podemos situar essas lutas em outro sistema que não o Ics, a região dos traços mnemônicos das coisas (em oposição aos investimentos de palavras). Lá também ocorrem as tentativas de desligamento do luto, mas nesse último nada impede que esses processos continuem pela via normal até a consciência, através do Pcs. Esse caminho se acha bloqueado para o trabalho da melancolia, talvez devido a muitas causas ou à ação conjunta de causas. A ambivalência constitucional pertence, em si, ao reprimido; as vivencias traumáticas com o objeto podem ter ativado outro material reprimido. Assim, tudo que diz respeito a esses conflitos da ambivalência permanece subtraído à consciência, até que sobrevém o desenlace característico da melancolia. (FREUD, 1917[1915]/ 2010, p.191)

O trabalho de melancolia deveria garantir a possibilidade de se efetuar a escolha de um objeto diferente, visando à liquidação de um investimento narcisista mesmo que esse novo objeto seja, como o antigo, assim investido. Veríamos, na repetição dos acessos melancólicos, o trabalho de melancolia que por um deslocamento arduamente realizado leva à reedição do seu modo de investimento privilegiado. O que se esperaria como objetivo com esses pacientes é a "objetificação" tanto quanto possível de seu investimento, isto é, transformar a maior quantidade possível em investimento do tipo objetal anaclítico. A elaboração viria através de uma identificação que tornaria o trabalho de melancolia possível. A retirada da libido para o eu e a transformação que se seguem permitem que a ambivalência se torne consciente, uma vez que ela se tornou um conflito entre as instâncias intrapsíquicas. O problema é que a identificação - onde o ser substitui o ter - parece ser a única via de elaboração possível. Freud (1917[1915]/2010, p.192) nos mostra as dificuldades encontradas no caminho do melancólico:

Assim, tudo que diz respeito a esses conflitos da ambivalência permanece subtraído à consciência, até que sobrevém o desenlace característico da melancolia. Ele consiste, como sabemos, em que o investimento libidinal ameaçado abandona finalmente o objeto, mas apenas a fim de se retirar para o lugar do $\mathrm{Eu}$, de onde havia partido. Refugiando-se do Eu, o amor escapa à eliminação. Após essa regressão da libido, o processo pode se tornar consciente e é representado na consciência como um conflito entre uma parte do Eu e a instância crítica.

A identificação irá oferecer a saída para o eu que fica imobilizado entre duas impossibilidades, a de desinvestir o objeto e a de continuar a existir. Conhecemos a 
relação da identificação com a desintrincação pulsional, principalmente através do superego. Este, como sabemos,

nasceu de fato por identificação com o modelo paternal. Toda identificação deste gênero tem a característica de uma dessexualização ou mesmo de uma sublimação. Ora, parece que em semelhante transposição ocorre também uma desunião pulsional. O componente erótico não tem mais, depois da sublimação, a força para ligar a totalidade da destruição que ali se associava, e essa última torna-se livre como tendência à agressão e à destruição. É dessa desunião que o ideal, em geral, [o supereu] retiraria seu traço de dureza e crueldade, aquele do dever imperativo. (FREUD,1923)

O trabalho de melancolia para oferecer uma possibilidade de saída para o melancólico deve garantir um investimento objetal através do reencontro de um novo objeto, ao mesmo tempo que propicia o desapego com o objeto perdido. Não seria esse movimento a própria sublimação? Com efeito, na criação, assim como no reinvestimento melancólico, os traços do antigo objeto permanecerão disfarçados e transformados no novo objeto. Localizamos aqui também os elementos que irão colocar limites à sublimação.

A seguir, iremos discutir um mecanismo defensivo que complica ainda mais a elaboração e a unidade do eu. Os conflitos também podem ser manejados através de uma divisão que irá separar o eu em partes, cada uma dela respondendo a uma exigência, interna ou externa. Por isso, a noção de clivagem nos será cara para seguir a investigação da melancolia.

\subsubsection{A clivagem}

$\mathrm{Na}$ teoria freudiana, clivagem é um mecanismo que só será tratado a fundo na segunda teoria pulsional. Na definição de Laplanche e Pontalis (1988, p.101), a clivagem do ego é uma expressão usada por Freud

para designar um fenômeno muito particular que ele vê operar sobretudo no fetichismo e nas psicoses: a coexistência, no seio do ego, de duas atitudes psíquicas para com a realidade exterior na medida em que esta vem contrariar uma exigência pulsional: uma tem em conta a realidade, a outra nega a realidade em causa e coloca em seu lugar um 
produto do desejo. Estas duas atitudes persistem lado a lado sem se influenciarem reciprocamente.

Encontraremos uma proximidade entre a identificação narcísica e o mecanismo de clivagem. Florence (1994, p.131) irá nos dizer que o próprio de uma identificação narcísica "é conservar um vínculo em que o objeto e o eu são os duplos um do outro. [...] Ela é a mais primitiva e mais importante em seus efeitos: ela constitui o próprio e suas clivagens”. Com Ferenczi (1931, p.76-77), a clivagem do eu também será pensada em relação ao abandono, e ao desamparo:

Tem-se nitidamente a impressão de que o abandono acarreta uma clivagem da personalidade. Uma parte da sua própria pessoa começa a desempenhar o papel da mãe ou do pai com a outra parte, e assim torna o abandono nulo e sem efeito". No entanto, o resultado produzido é o de uma cisão na qual a parte sensível se encontra brutalmente destruída, enquanto a outra parte "sabe tudo, mas nada sente".

O escritor e filósofo francês Blanchot afirma que "o artista mais talentoso, cada vez que se empenha numa nova obra, fica desamparado e como que privado de si mesmo" (BLANCHOT, 1984, p. 142). De acordo com Kupermann (2006), será a emergência do abandono o que irá causar a chamada "confusão de línguas"60 entre os adultos e a criança, fazendo com que a última, se desamparada, seja obrigada a se haver com o enigma que viria com a culpa que é transmitida pela linguagem própria dos adultos, a linguagem da paixão. Em suas palavras:

Como efeito deste abandono, e por não poder prescindir do amor do agressor (por sua vez objeto privilegiado de amor da criança), a solução psíquica encontrada é a incorporação do agressor bem como de seu sentimento de culpa enigmático, que dá origem a uma clivagem através da qual a criança procura proteger a si própria. (KUPERMANN, 2006)

\footnotetext{
${ }^{60}$ Ferenczi (1933/1984) insiste que o importante é que a criança, ainda com uma personalidade em desenvolvimento, ao invés de se defender, introjeta aquilo que a ameaça. Para o autor, a época da identificação, referida por Freud, é um estágio de amor objetal passivo, ou o estágio da ternura. Neste estágio somente ocorreriam características de amor objetal na fantasia, pois, por mais que as crianças imaginem-se ocupando o lugar de um progenitor, elas não poderiam ir além do estágio da ternura. Se nesta fase um adulto impõe à criança outra forma de amor que elas não desejam e nem podem concretizar, um amor objetal erótico, ocorre a confusão de "línguas" entre criança/adulto". (PINHEIRO, 1996, p. 52).
} 
De acordo com Rosenberg (2003, p.169), a lógica de criação do supereu não estaria muito distante daquela que encontramos na clivagem:

Assim, a criação da instância supereu está no interior do aparelho psíquico como o núcleo masoquista erógeno-primário, mas está no exterior do eu como está a pulsão de morte derivada projetada para o exterior. Do ponto de vista do eu, é uma espécie de projeção fora de si. Mas uma projeção, se assim podemos dizer, no interior do aparelho psíquico, uma espécie de projeção interna. Certamente, o eu sacrifica para isso uma parte de si que irá se tornar uma outra instância no aparelho psíquico, mas com esse sacrifício ele próprio se encontra ao abrigo dos efeitos diretos e destruidores da pulsão de morte.

O grau extremo de desintrincação que ainda é compatível com a vida parece ser a clivagem de objeto ${ }^{61}$ e a clivagem do eu. A clivagem é uma decomposição da entidade que conhecemos como "eu", um corte, uma fenda - que corresponderia a uma das formas mais extremadas da ação da pulsão de morte no interior do aparelho psíquico. Essa desintrincação pulsional

coloca a libido diante de um objeto não estruturado, não diferenciado dentro de si mesmo, um objeto que a libido só pode investir em tudo ou nada, e em tudo, e imediatamente. O investimento pode ser tão massivo que o sujeito tem dificuldade em se sentir diferente do objeto e sente-se, antes, investido-invadido pelo objeto. Depois desse investimento massivo, direto, não mediado, o sujeito vive uma formidável excitação que se torna rapidamente insuportável. Esses dois lados da intrincação pulsional, por um lado, a recusa e a clivagem do eu, obra de uma pulsão de morte desintrincada e, por outro, o investimento massivo e a excitação insuportável, obra de uma libido desintrincada, são certamente os dois aspectos complementares do quando que os psicóticos apresentam. (ROSENBERG, 2003,p.166)

A recusa funcionaria como uma fronteira - a clivagem do eu - que protegeria o eu e lhe forneceria um setor objetal compatível com suas capacidades de trabalho.

O objeto recusado, é evidente que, se ele era a fonte de grande excitação, é porque era um objeto muito investido, portanto um objeto de uma importância capital para o eu. Não acreditamos que mesmo a recusa mais bem-sucedida possa apagar completamente um objeto tão importante para o eu sem deixar pelo menos o sentimento

\footnotetext{
${ }^{61}$ A clivagem do objeto é um "mecanismo descrito por Melanie Klein e por ela considerado como a defesa mais primitiva contra a angústia: o objeto, visado pelas pulsões eróticas e destrutivas, cinde-se num "bom" e num "mau" objeto, que terão então destinos relativamente independentes no jogo das introjeções e das projeções. A clivagem do objeto opera particularmente na posição paranóide-esquizóide, em que incide sobre objetos parciais. Reencontra-se na posição depressiva, em que incide então sobre o objeto total" (LAPLANCHE, PONTALIS, 1988, p.144).
} 
inconsciente de uma falta, de uma privação, de um lugar vazio conservado em negativo, se assim podemos dizer, a forma de um objeto recusado. Acreditamos que o sentimento correspondente a esse lugar vazio não seria suportável se não fosse contra-investido de maneira masoquista. Acreditamos que toda recusa é acompanhada de uma vivencia masoquista inconsciente, masoquismo que liga e domina o sofrimento inconsciente do vazio do objeto recusado. Acreditamos que a vivência masoquista que supomos com relação ao objeto recusado seja um esboço de elaboração sem o qual nossas psicoterapias de psicóticos teriam pouca chance de sucesso. (ROSENBERG, 2003, p. 197, grifos nossos.)

Uma das figuras do movimento de intrincação e desintrincação pulsional é a negação e, consequentemente, seus predecessores, a expulsão, a projeção. A pulsão de morte é o elemento que coloca o outro a uma distância suportável, uma vez que cria uma boa relação entre a libido e seu objeto e permite a elaboração do desejo ao evitar o conluio entre o desejo e seu objeto - como seria o caso de algumas passagens ao ato na psicose. Assim, mesmo na neurose, há necessariamente a presença da pulsão de morte: “A mudez da pulsão de morte na neurose é a obra de uma intrincação pulsional que teve sucesso" (ROSENBERG, 2003, p. 167).

Novamente somos confrontado com o caráter paradoxal do trabalho de melancolia. No luto, é necessário primeiramente um reinvestimento e até mesmo um superinvestimento do objeto. Observamos, no enlutado, a onipresença do objeto em seu cotidiano e em seus sonhos. Já no trabalho de melancolia, para que o desinvestimento narcisista se dê, o objeto deverá ser rebaixado e depreciado na tentativa torná-lo indigno de investimento. O trágico é que esse objeto que precisa ser rebaixado é introjetado, sendo que o ataque a si mesmo disfarça o ataque que é feito contra o objeto. Mas, entendemos com Freud (1917[1915]/2010, p.174) que,

a solicitação desta [tarefa do trabalho de luto] não pode ser atendida imediatamente. É cumprida aos pouco, com grande aplicação de tempo e energia de investimento, e enquanto isso a existência do objeto perdido se prolonga na psique. Cada uma das lembranças e expectativas em que a libido se achava ligada ao objeto é enforcada e superinvestida, e em cada uma sucede o desligamento da libido.

O que iremos ver é que a identificação pela regressão narcisista não leva a uma tomada de consciência verdadeira. Tanto no trabalho de luto quanto no de melancolia o objeto morre enquanto tal. Segundo Rosenberg (2003, p.140)o investimento narcisista de objeto "estando ligado à idealização do objeto, no melancólico certamente, essa 
desvalorização tem como objetivo atacar a idealização do objeto, torná-la impossível”. Ou seja, metapsicologicamente, o autor nos mostra que

\begin{abstract}
trata-se de mobilizar o ideal do eu do sujeito para destruir a idealização do objeto, torná-la impossível; incongruente com esse ideal de eu. Mas não se deve esquecer que esse ataque, desvalorizando o objeto, passa pela introjeção do objeto, o que faz com que aquilo que vemos clinicamente seja uma desvalorização, um menosprezo de si que dão a impressão de que esse ideal do eu do sujeito esmaga esse último, enquanto na realidade ele está mobilizado para esmagar o objeto (mortalmente). (ROSENBERG, 2003, p.140)
\end{abstract}

Vemos que tanto o ideal do eu quanto o supereu estão em jogo e a desvalorização do objeto é acompanhada também da culpabilização do mesmo, não somente do eu. O eu, por sua vez, se sente culpado e também culpa o outro buscando de algum modo o controle ativo do que foi vivido passivamente. O ideal do eu atua na destruição do objeto pela desvalorização e o supereu "acusa o objeto de apresentar-se como tendo valor quando só se trata de fingimento" (ROSENBERG, 2003, p. 141). A acusação da impostura do objeto pelo superego é interessante. Nesse momento de acusação do objeto, observamos novamente a ideia de logro apresentada por Lambotte (1997). O eu poderia assim dizer: "Não sou eu, é o outro que é falho". Talvez resida aí o efeito terapêutico que percebemos nos sujeitos que podem reconhecer conscientemente no outro quem falhou, quem faltou na hora dos cuidados, desidentificando-se com o objeto. Paradoxalmente, culpar o outro, atacar o outro (externo) é um caminho para que a identificação com o ausente possa acontecer.

A descrição que estamos tentando fazer do discurso melancólico parece estar próxima do que Joseph (1992) chamou “o vício pela quase morte”. No artigo homônimo, não se buscou examinar o valor defensivo do vício, mas há um outro aspecto que se quer mencionar:

Trata-se de algo relacionado com a tortura e sobrevivência. Nenhum dos pacientes que tenho em mente como estando particularmente incluídos nesse grupo viciado tem, na realidade, uma história de infância muito ruim, embora psicologicamente, num certo sentido, eles quase certamente tiveram - como por ex. uma falta de contato caloroso e de compreensão verdadeira, e algumas vezes um progenitor muito violento. No entanto, na transferência, temos a impressão, como indiquei, de estarem sendo empurrados para o limite das coisas, e tanto o paciente como o analista sentem-se torturados. A partir da dificuldade que esses pacientes sentem de esperar e de tomar consciência de descontinuidades ou mesmo do tipo mais simples de culpa, fiquei com a impressão de que eles sentiram essas experiências 
potencialmente depressivas na tenra infância como uma dor terrível que se transformava em tormento, e que tentaram evitá-la, assumindo eles próprios o tormento, infringindo dor mental a si mesmos e edificando-a num mundo de excitação perversa, o que necessariamente milita contra qualquer progresso real em direção à posição depressiva. É muito difícil para nossos pacientes achar que é possível abandonar esses terríveis deleites pelos prazeres incertos dos relacionamentos reais. (JOSEPH,1992, p.143, grifos nossos)

A relação do sadismo superegóico aparece em sua maioria das vezes como um efeito da introjeção das vozes parentais, o que poderia levar à suposição de que o tratamento dispensado à criança nesses casos sempre aconteça sob a égide de alguma forma de violência parental. Contudo, iremos perceber que, em diversos casos, que o ambiente externo cuidou para que tudo se passasse bem para aquele bebê que representa o narcisismo reeditado dos pais. Como Freud (1914) nos diz, à "Majestade o bebê" são dadas as condições que muitas vezes os pais não tiveram na infância, sendo que estes procuram escapar ao destino de reproduzir, com o filho, o que os seus próprios pais fizeram com eles. O dramático será perceber que, mesmo com todo o cuidado e atenção dos pais para fugir às determinações familiares o filho pode, ainda sim, padecer de um sofrimento narcísico, trazendo à tona o que é estranhamente familiar. Lambotte (2000, p.72) nos diz que

É de fato uma identificação falhada que se trata quando, para além do pai austero e piedoso, o filho descobre 'tudo o que há por trás, sem ousar no entanto, sabê-lo'. Como compreender a imagem de um pai ideal que deixa transparecer, apesar de sua real sabedoria, a angústia existencial que o filho se apressa em ligar a erros supostos, a partir de pedacinhos incompreensíveis escapados ao acaso?

Podemos pensar aqui em uma identificação que acontece entre o superego dos pais com o superego dos filhos, o que os levaria a reencenar os conflitos paternais que tanto se buscou controlar ou superar. Veríamos assim que uma transmissão transgeracional do trauma poderia representar uma faceta da compulsão à repetição e da neurose de destino. A "escolha da neurose" nesses casos seria ainda menos livre, quase uma contradição entre termos.

Daremos prosseguimento ao nosso trabalho, trazendo a contribuição trazida por Klein (1940) sobre o período arcaico de constituição do ego, demonstrando que a elaboração de uma "posição depressiva" é central a todo desenvolvimento psíquico humano. Lambotte (1997) também aponta a necessidade de se investigar o que ela 
chamou de "fase depressiva constitutiva", para entendermos a relação entre a sublimação e a melancolia. Ela pergunta:

[...] não seria legítimo interrogar-se sobre a pertinência das sequelas de uma fase depressiva constitutiva, originalmente, da sublimação, vestígio da efetuação do luto dos objetos desaparecidos? (LAMBOTTE, 2000, p.86)

A característica inerente à pulsão é a de substituir um objeto por outro em busca de satisfação, sendo esta, sempre impossível. Nesse sentido, a pulsão se confundiria com a própria capacidade sublimatória, que faz com que o circuito pulsional busque novos modos de encontrar a satisfação. Ao melancólico é colocado o mesmo desafio que é posto à sublimação: em ambos os casos há um objeto que não mais pode ser investido. Contudo, o melancólico é impossibilitado de desinvestir o seu objeto de amor, sob o risco de perder a si mesmo no processo. Perguntamos com Schneider (1990, p.415):

A escritura não é a própria melancolia? Interpretação depreciativa e interminável de si por si mesmo, projeto vão de falar de um assunto vão: si mesmo? Foi "um humor melancólico que - confia Montaigne, que inicialmente enfiou-me na cabeça esse sonho de me meter a escrever". Como se estivesse em jogo, mais que um motivo sobre o qual muito se escreveu, o próprio movente da escritura, sua condição íntima. No sentido da medicina do século dezesseis, a melancolia, o humor negro, estado de despojamento de si mesmo leva incontestavelmente a escrever.[...]Se não se manifesta profunda demais, engolindo o eu que escreve no desmoronamento do eu vazio, a melancolia leva a escrever, a acariciar amorosamente o oco do próprio ser, a preencher o vazio de si mesmo com a escritura de mim.

Reiteramos a questão: como e quanto da capacidade de sublimação dos melancólicos se encontraria comprometida? Observamos que o processo criativo está presente nos sujeitos melancólicos, mas qual seria a diferença na economia e na dinâmica da sublimação nesses sujeitos? Esperamos traçar ao longo do trabalho os elementos que respondam a essas questões. 


\title{
Cap III - Ampliando a visão: Klein e Winnicott
}

\author{
Mãe se escreve com M maiúsculo \\ máscula forma de perder \\ a mulher já dada e tida e viva apesar \\ de mim apenas por querer \\ a leitura amarga dessa letra \\ projeto ressentido de viver \\ como escrevê-la se existir não cabe \\ na culpada dúvida do ser? \\ (CÉSAR,2008,p.120)
}

\subsection{Contribuições Kleinianas: posição depressiva, sentimento de culpa, reparação e sublimação.}

O artigo "Amor culpa e Reparação" (1937) é fundamental no desenvolvimento das ideias propostas mais elaboradamente por Klein sobre a posição depressiva do aparelho psíquico, tal qual em seus artigos: "Uma contribuição para a psicogênese dos estados maníaco-depressivos" (1935) e "O luto e sua relação com os estados maníacodepressivos" (1940). Klein (1937, p.347) preferia usar o termo posição ao termo fase, compreendendo que assim seria capaz de abarcar toda a organização psíquica, a natureza das relações de objeto, as fantasias, as defesas, bem como todas as implicações das mudanças que ocorrem no desenvolvimento do ego. Ela sublinha a necessidade de trabalharmos a interação entre o amor e o ódio desde os momentos mais arcaicos de funcionamento psíquico. A compreensão do papel desempenhado pelos impulsos destrutivos nessa interação seria capaz de mostrar como os sentimentos de amor e as tendências de reparação se desenvolvem em ligação com os impulsos agressivos, ou apesar deles.

Para compreendermos a posição depressiva, devemos considerar a importância do sentimento de ambivalência que o melancólico mantém com o objeto perdido. A criança ainda incapaz de suportar a mínima frustração à sua demanda, a percebe como uma traição e ataca o objeto que foi responsável pelo seu desprazer. A partir do momento em que o objeto total é percebido, isto é, quando a criança concebe que, o mesmo objeto que é fonte de amor e apaziguamento, também é aquele que frustra, surgem ansiedades e dor diante da possibilidade de que as tendências agressivas dirigidas ao "objeto mau" 
possam destruir o seu objeto de amor, ou seja, “objeto bom”. Portanto, a situação primordial para a análise dos sentimentos de amor e de ódio é a relação do bebê com a mãe, uma vez que ela é simultaneamente o primeiro objeto de amor e de ódio do bebê. A criança ama a mãe quando ela a alimenta, alivia sua fome e oferece o prazer sensual que é obtido pela estimulação da boca pelo seio. A gratificação que é assim percebida constitui parte essencial da sexualidade da criança e é sua expressão inicial. De maneira oposta, quando o bebê sente o desconforto da fome, não tem seus desejos e necessidades físicas atendidas, ou quando sente dor, sentimentos de agressividade e ódio surgem ao mesmo tempo em que o bebê é tomado por impulsos de destruir a mesma pessoa que é objeto de todos os seus desejos. A criança ainda não sabe que o objeto contra o qual ela nutre ambos sentimentos é o mesmo. A partir do momento em que essa compreensão se dá, ela se vê compelida a reparar os danos que pode ter causado ao objeto amado. O sentimento de culpa surge, nesse panorama, onde acontecem as primeiras atividades mentais reconhecidas como pensamento imaginativo e na construção da fantasia que acompanha os sentimentos e vivências do bebê. $O$ mundo interno "seria o lugar dos objetos do superego que, por outro lado, representam dentro do psiquismo as funções intersubjetivas exercidas pelos objetos primários" (FIGUEIREDO, 2012, p.257).

Conforme o pensamento kleiniano (1937, p.389) as fantasias destrutivas possuem uma equivalência a verdadeiros desejos de morte. Isto é, para o bebê, é como se aquilo que desejou nas suas fantasias realmente tivesse acontecido, o que tem consequências importantíssimas para o desenvolvimento do eu, uma vez que é como se "realmente tivesse destruído o objeto de seus impulsos destrutivos e continuasse a destruí-lo". O sujeito teme uma retaliação, pois acredita que as armas empregadas para destruir o objeto também se voltam contra si mesmo.

O bebê irá buscar se defender dessas fantasias destrutivas com fantasias onipotentes de caráter restaurador, entretanto, o medo de ter destruído o objeto do qual mais ama e depende não consegue ser eliminado. Esses conflitos básicos afetam profundamente a força da vida emocional e o desenvolvimento do indivíduo adulto. Segundo a autora (KLEIN,1940, p.394):

O desejo de controlar o objeto, a gratificação sádica de dominá-lo e humilhá-lo, de sobrepujá-lo, o triunfo sobre ele, podem participar com tanta força do ato de reparação (realizado através de pensamentos, atividades ou sublimações) que o círculo "benigno iniciado por esse ato se rompe. Os objetos que deveriam ser restaurados se transformam 
novamente em perseguidores e os medos paranóides voltam à tona. Esses medos reforçam os mecanismos de defesa paranóides (de destruir o objeto) assim como os mecanismos maníacos( de controlálo ou mantê-lo em animação suspensa, e assim por diante). A reparação em progresso então é prejudicada ou anulada dependendo da intensidade com que esses mecanismos são ativados. Como consequência do fracasso do ato de reparação, o ego se vê obrigado a recorrer constantemente a defesas obsessivas e maníacas.

Desse modo, compreendemos que, quando o indivíduo percebe impulsos de ódio em si mesmo contra alguém que ama, sente-se culpado ou preocupado. Esses sentimentos se manifestam disfarçadamente e são fonte de perturbação nas nossas relações pessoais, como observamos nas várias nuances de insatisfação consigo mesmo ou no que é conhecido popularmente como "baixa-estima". Segundo Klein (1937, p.350), eles teriam suas raízes no sentimento "inconsciente" de culpa:

Esse sentimento surge do medo inconsciente de ser incapaz de amar os outros de verdade ou de forma suficiente e, principalmente, de não conseguir dominar seus próprios impulsos agressivos: essas pessoas têm medo de ser um perigo para aqueles que amam.

A semelhança do que aqui é descrito com o que observamos em pacientes melancólicos é notável, já que a diminuição da auto-estima e o auto-envilecimento são condições para a melancolia. Lemos em um poema de Ana C. (1998, p.171):

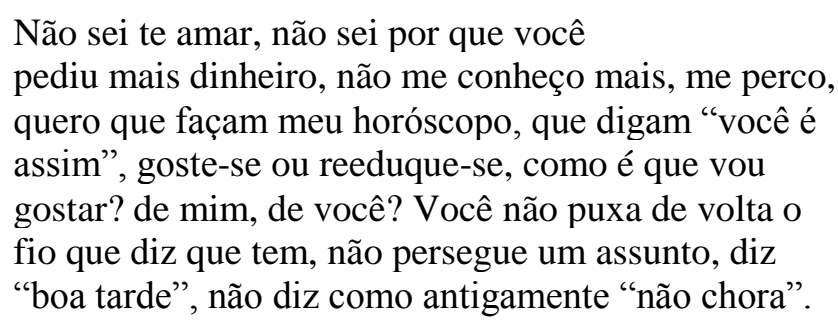

Há um avanço muito importante no desenvolvimento quando surgem, na mente do bebê, os conflitos de amor e de ódio e o medo de perder o objeto amado. Os sentimentos de culpa e de sofrimento aparecem como um elemento novo na emoção do amor, uma vez que a criança irá se preocupar tanto com o objeto quanto com seu destino, a partir das ações (mesmo que fantasiadas) que foram por ela produzidas. Ademais, ela também se sente compelida a fazer sacrifícios a fim de reparar, e restaurar, as pessoas que foram feridas em sua fantasia. Percebemos que existe uma capacidade de se identificar com o outro, de se colocar no lugar deste e perceber o que ele estaria sentindo, o que é um 
elemento importante para os verdadeiros sentimentos de amor. É interessante perceber que, nessa operação de buscar reparar o outro, realiza-se no presente, algo que gostariase de ter realizado no passado, o que possui também um caráter reparador para o próprio eu.

O sentimento de culpa e a necessidade de reparação estão profundamente ligados à emoção do amor. A resolução do conflito entre amor e ódio arcaicos nos dará indicações de como o indivíduo maneja suas relações amorosas posteriores. Se a culpa for extremamente forte, pode ser que isso leve ao afastamento ou rejeição da pessoa amada, pois, é o medo de que ela possa morrer em decorrência dos ataques que lhe são feitos em fantasia (como foi inicialmente a mãe), que torna intolerável a dependência em relação a essa pessoa (Cf: KLEIN, 1937, p.362). Observa-se como a criança busca a sua independência em relação à mãe e se regozija com suas primeiras conquistas e êxitos que, de certa forma, a apazigua de não precisar tanto daquela pessoa que lhe é fundamental. Na fantasia inconsciente da criança, a mãe protetora que está sempre ali para realizar os cuidados necessários e satisfazer as suas vontades é tomada como uma parte inseparável, desse modo, a morte da mãe amada implicaria a morte do próprio sujeito. Segundo Klein (1937, p.362), "quando esses sentimentos e fantasias são fortes demais, a ligação com as pessoas amadas pode se tornar um fardo insuportável”.

O que encontramos como saídas possíveis para essas dificuldades é a redução da capacidade de amar, negando-a ou suprimindo-a, passando a evitar as emoções "mais fortes". Outra saída também pode ser o deslocamento do investimento amoroso para objetos inumanos, como a ciência, os animais, coleções de objetos, entre outros. É possível também encontrarmos casos onde existe uma grande dependência em relação ao objeto amoroso, o qual pode funcionar como uma fuga da responsabilidade pelas próprias ações. Nesse caso, observa-se que o amor é fundamental contra o sentimento de culpa e vários tipos de medo: é necessário que a pessoa amada certifique para o indivíduo que o ama e através dos sinais de sua afeição indique que ele não é "mau", que seus impulsos destrutivos não tiveram efeito mortal.

Para Klein, o sentimento de culpa é um incentivo fundamental para a criatividade e o trabalho em geral. Contudo, ele pode inibir as atividades produtivas caso seja muito intenso. A observação da análise de crianças através do brincar, por exemplo, demonstra que, quando os medos são atenuados, a atividade criativa aumenta e os impulsos destrutivos se reduzem. Nesse escopo, ocorre uma diminuição gradual do sentimento de culpa e da ansiedade em torno da morte da pessoa amada, que eram muito 
pesados para uma criança suportar. Uma vez tornados menos intensos e mais fáceis de controlar, o desejo de fazer a reparação pode se expressar construtiva e criativamente. Essa possibilidade também pode ser observada na análise de adultos. Em "Uma contribuição à psicogênese dos estados maníaco-depressivos", ela nos diz que:

ao lidarmos com a etiologia, parece essencial não nos limitarmos a encarar a disposição da libido apenas como tal. É preciso também estudá-la em conexão com as primeiras relações do sujeito com seus objetos externos e internalizados, reflexão que implica compreender os mecanismos de defesa desenvolvidos gradualmente pelo ego ao lidar com suas diversas situações de ansiedade. (1935, p.309)

Os efeitos mortíferos da pulsão de morte são especialmente visíveis na compulsão à repetição, nos imperativos tirânicos do superego, no masoquismo moral, nos sonhos repetitivos da neurose traumática, na reação terapêutica negativa, na impossibilidade de representação, no desligamento, na inércia, no princípio do nirvana. Cintra (2011) aponta que na melancolia a ordem do superego seria a de purificar e destruir, sendo esta purificação a separação total das qualidades positivas daquelas que são negativas e, em seguida, tentar destruir aquilo que foi considerado ruim. A relação ambivalente se torna assim, ainda mais terrível.

Observamos, na teoria kleiniana, uma constante busca para compreender como os processos arcaicos e infantis permanecem no indivíduo adulto. O sentimento de culpa deve ser investigado na sua complexidade, uma vez que constatamos a sua importância no funcionamento mental e a sua capacidade de interferir em diversos aspectos da vida de um indivíduo. Se este sentimento está na base dos processos criativos, poderíamos dizer, então, que a criação é alimentada pelo núcleo melancólico do sujeito. Todos esses elementos corroboram nossa hipótese de que a sublimação irá retomar a maneira pela qual se dá a constituição do eu psíquico, suas primeiras relações de objeto e as marcas que essas primeiras experiências imprimiram no eu. $\mathrm{O}$ sentimento de culpa tem uma especial tendência de se disfarçar e intrometer-se em processos que the parecem estranhos. Na coletânea póstuma encontramos um poema escrito no período de 19821983, Ana C.(1998, p.174) escreve:

Tento até o velho golpe: recitar poemas para tua indiferença. Cabotina. Agarrada num rabo-de-cavalo. "Teus versos agora me tocam menos Que você". Tua mão vacila. Não é de cera 
Até que um dia com a unha tira a lasca do rosto e descubro

A identidade da morta por debaixo.

É porque tem que chegar. Perto do coração não tem palavra?

Como vimos anteriormente, a sublimação é pensada junto ao mecanismo de reparação. De acordo com Laplanche e Pontalis (1988, p.581), tal mecanismo descreve como o ego procura "reparar os efeitos produzidos no seu objeto de amor pelos seus fantasmas destruidores", desempenhando um papel fundamental no trabalho do luto e na sublimação. A reparação, então, seria tributária da posição depressiva e está intrinsecamente ligada a sentimentos de culpa.

Segal (1993, p. 95) analisa o artigo sobre arte, "Situações de ansiedade infantil refletidas numa obra de arte e no impulso criador" (1929), onde Klein se volta para o impulso criador. Lá, ela analisa uma jovem pintora sueca, Ruth Kjar, acometida por depressões recorrentes e sentia seu interior ser invadido por um espaço vazio, sendo compelida a pintar exatamente pela intolerância ao espaço vazio que havia sido deixado na parede por um quadro removido. Neste exemplo, será estabelecida uma direta relação entre a origem do impulso criador e a necessidade de reparação. Segal (1993, p. 96) acha interessante esse artigo preceder imediatamente ao trabalho de Klein sobre a formação de símbolos, uma vez que, em sua opinião, a formação de símbolos seria a própria essência da criatividade artística.

A partir do artigo kleiniano "Uma abordagem psicanalítica da estética” (1952), Segal (1993) irá sugerir que o impulso artístico está diretamente relacionado à posição depressiva, ou melhor, entenderíamos a criação como uma necessidade de se recriar o que sente nas profundezas de seu mundo interno. Seria "a percepção interna do sentimento mais profundo da posição depressiva - o sentimento de que seu mundo interno está estilhaçado - é que leva o artista a precisar recriar algo que seja sentido como um mundo completamente novo. Isso é o que todo grande artista faz - cria um mundo", que pertence exclusivamente à obra (SEGAL, 1993, p. 96). A autora nos diz, contudo, que, o trabalho de reparação do artista nunca é concluído. Outra observação que nos parece importante é a de que "alguns artistas sentem de modo particularmente poderoso que a obra adquire existência quase independente", e um aspecto importante da reparação é deixar que a obra se vá - a doação que o sujeito faz de sua obra para o mundo(SEGAL, 1993, p.106). Isto é, mesmo se a obra conseguir fazer o trabalho de 
reparação, ela poderá ser dispensada da sua função narcisante. Contudo, essa separação também pode gerar a sensação de estranho que o duplo traz. Kofman (1996, p.140) nos diz que a arte seria um duplo, e como todo duplo ele aparece para preservar ou defender o original, mas num segundo momento, ele se torna aquilo que é capaz de destruí-lo, ele se torna o representante da morte:

Esses duplos são constitutivos do verdadeiro ser do artista e de sua identidade: pois o fato de que este tenha de se desdobrar, se repetir, se representar, implica uma não-presença de si, uma insatisfação originária, a morte imanente à vida, a ausência de origem simples e plena. É por isso que, além do prazer preliminar devido ao "prêmio de sedução" oferecido pela beleza da obra, além do prazer decorrente da supressão da inibição, a arte proporciona ao artista, assim como ao público, um prazer narcísico análogo que o sonho dá. Com a diferença de que por meio dela pode se tornar universal, graças à identificação. Por isso Green (1994) pode designar a arte, com toda razão, como um objeto transnarcísico.

Segal (1993, p.108) nos oferece mais argumentos importantes:

[...] parte da dificuldade na arte é que ela deve satisfazer tanto o anseio por um objeto ideal e por um self fundido com esse objeto como a necessidade de restaurar um objeto inteiro realisticamente percebido, uma mãe superada não fundida com o self. Adrian Stokes sugere que o sentimento particular de ser arrastado para dentro de uma obra de arte e nela ficar envolvido contém elementos da fusão pré-depressiva com o objeto ideal. Mas o artista também tem de emergir disso para ser de algum modo criativo.

A autora também irá fazer uma análise sobre Richard Holmes, um escritor de biografias - que nos é muito útil para pensar a dimensão autobiográfica na obra de Ana C. Ele irá descrever o processo de escrever uma biografia

biografia como algo que tem dois estágios principais. O primeiro deles é o relacionamento ficcional vivo e uma identificação profunda, uma forma de identificação que ele chama também de "auto-projeção". Ele diz que, em certo sentido, isso é um estado mental pré-biográfico, préliterário, que é motivação essencial para seguir os passos de alguém. (In: SEGAL, 1993, p. 108).

Ele diz ainda que "o verdadeiro processo biográfico começa precisamente no momento e nos lugares em que essa forma ingênua de amor e identificação sucumbe. $O$ momento de desilusão pessoal é o momento de recriação impessoal, objetiva." 
(SEGAL, 1993. p. 108). Ou seja, até mesmo para conseguirmos falar sobre a pessoa a ser biografada, é preciso, depois da identificação com ela ou sua obra, uma desidentificação. Para esse biógrafo,

o colapso da idealização e da identificação induziu nele o mais negro desalento, mas foi também o momento de criação. Holmes posteriormente fala de outra descoberta: a de que o sujeito individual de uma biografia é uma quimera.[...] 'é nesse sentido que toda evidencia biográfica real é evidência em "terceira pessoa" - evidência que é testemunhada. [...] Nesse sentido o biógrafo está continuamente sendo excluído, ou alijado, da comunicação ficcional que estabeleceu com seu sujeito.(SEGAL, 1993, p.108, grifos nossos).

Desse modo, por mais que busquemos os dados biográficos de Ana C., sabemos que a nossa leitura envolve uma construção, que foi facilitada pelo efeito que sua poesia nos causou, isto é, sabemos que a obra de arte não se resume ao artista.

Concordamos com Segal (1993, p. 104) que, "é um paradoxo que a obra do artista seja nova e, no entanto, surja da ânsia de recriar ou restaurar. Esse paradoxo é inerente ao simbolismo". Como sabemos por Freud (1908), o artista é um devaneador, mas ele volta à realidade externa, nunca a deixa inteiramente. Segal (1993, p.105) irá falar sobre a diferença entre o artista e o artesão:

Em primeiro lugar, ele tem uma consciência aguda de suas realidades internas, da realidade interna que busca expressar. Mas uma apreensão de uma realidade interna caminha sempre com a dificuldade de diferenciar o que é interno do que é externo e, portanto, também com um senso da realidade externa - uma diferença básica entre criatividade e delírio. $\mathrm{O}$ artista deve ter uma destacada percepção da realidade do potencial e das limitações de seu instrumento, limitações que tanto usa como tenta superar. Ele não é só um sonhador, mas um artesão supremo. $\mathrm{O}$ artesão pode não ser um artista, mas um artista deve ser um artesão. E por via de regra ele está vivamente ciente disso.

Ela enumera um grande número de artistas que pararam de criar ou morreram em torno da idade de 37 anos, contudo, aqueles que conseguiram ultrapassar a crise, pareceram amadurecer e mudar o método e estilo de trabalho, vivendo até idade avançada, a exemplos de Picasso e Henry Moore. A autora também indica que no adeus à junventude e à infância representada pela crise de meia-idade é necessária uma nova elaboração das ansiedades depressivas, sendo que a perspectiva da própria morte deve ser encarada realisticamente. Seria a necessidade de resolver conflitos internos que forçariam alguns artistas a começar a criar somente após a crise de meia-idade. A 
"Interpretação dos sonhos" (1900) de Freud teria começado a ser escrita por volta dessa idade e Klein também se torna analista nesse período. Assim, a autora considera que "a criatividade artística é uma maneira de expressar e elaborar as ansiedades da posição depressiva. Sugiro, também, que isso depende da aceitação da própria mortalidade" (SEGAL, 1998.p.136).

Seguiremos a indicação de Segal e iremos pensar a relação da melancolia e da sublimação com o tempo. Antes, porém, falaremos um pouco sobre algumas compreensões winnicotianas necessárias para o desenvolvimento de nosso argumento.

\subsection{Contribuições Winnicottianas: a criatividade, o núcleo silencioso do eu e o rosto como espelho} "Seu olho enxerga, mas seu corpo não." Você não reparou ainda que
daqui não apago o desejo escuro, a cara metade do meu rosto, de fio
a pavio com furor de luta preso numas mãos bem brancas.

Ana C. (1998, p.143)

Para o psicanalista e pediatra Winnicott, suas observações do crescimento infantil indicaram que o essencial era viver de forma criativa. Não nos surpreende o fato de que a noção de pulsão de morte encontrou resistência no pensamento deste autor. Para ele, o chamado "verdadeiro self" seria resultado de um êxito repetido da função materna, quando ela responde ao gesto espontâneo ou à alucinação sensorial do bebê. A criança precisa ouvir o eco de seu movimento no mundo, sentir que alterou a realidade de alguma forma, contudo, seria preciso a preservação de um espaço que não poderia ser invadido por esse outro cuidador. Segundo Winnicott, haveria um núcleo secreto no coração do psiquismo, um elemento que não seria comunicável, cuja preservação é preciosa - o que vai contra a regra fundamental da psicanálise: “tudo dizer". Em um poema escrito em janeiro de 1982, lemos:

[...]retomo o caderno terapêutico depois de ter dito que a minha cura era "falar tudo", que me desse e me viesse, e assim, angustiada com a partida que me cala ou um flanco de mim, escrevo como quem fala tudo,[...] senti que meu compromisso era com a mulheres, com o colo delas, e só secundariamente com ele, com um apelo da realidade muda.[...] Volto para a casa de mamãe, e tenho de suportar a angústia de ter que me emudecer até a Mary voltar(CÉSAR, 1998, p.135). 
Voltando à teoria winnicotiana, cada atividade feita pelo bebê e o trabalho de tradução da mãe possibilitarão que as vivências, uma a uma, entrem na esfera de onipotência do bebê. A formação de uma unidade depende da experiência de ser contido e de conter, relacionada ao conhecido modelo canibalista que Freud localiza na fase oral. Ali, é feita uma transposição para o psíquico das primeiras formas de interação com o mundo, que se dá através da boca, dos lábios, língua e seio. A partir dessas experimentos o bebê irá buscar seus equivalentes simbólicos, desse modo, o tampar e encaixar pinos nos buracos amplia o espaço que servirá de piso para as futuras brincadeiras mais complexas. Se tudo corre bem, o interesse do bebê se amplia e ele estará pronto para essas novas simbolizações que envolvem o brincar e o falar. A partir daí, poderá encontrar narrativas para ilustrar suas histórias, chegando, assim, à simbolização secundária. É quando se pode localizar a psique no corpo que o pequeno sujeito pode experimentar o "gesto espontâneo", movimentos estes que fazem com que ele se aproprie das sensações correspondentes a essa etapa inicial. As necessidades corporais são aos poucos transformadas em vontades do ego e as experimentações físicas levam a uma elaboração imaginativa.

O sentimento de ser real é acompanhado de uma capacidade cada vez maior de suportar as rupturas da continuidade da vida e as experiências reativas do eu que é submetido a seu ambiente. Caso esses processos iniciais fracassem, uma alternativa de sobrevivência do eu é o isolamento. A necessidade constante de reação a um ambiente hostil resulta em uma perda temporal do "sentimento contínuo de existir" e provoca angústias impensáveis, primitivas. Essas agonias primitivas incluirão o medo de retornar a "um estado não integrado; cair para sempre; perda do conluio psicossomático, fracasso da despersonalização, perda do senso do real; perda da capacidade de relacionar-se com objetos". (Cf: WINNICOTT,1963, p.72) Winnicott irá afirmar que o medo do colapso é o medo de um colapso que já foi experienciado. Ele é um temor da agonia original que provocou a organização de defesa que o paciente apresenta. A importante indicação desse psicanalista irá mostrar que é preciso dizer para o paciente que aquilo que é o seu maior temor, já aconteceu. Entendemos, assim, que a antecipação dos términos de suas relações e em última instância, da morte, seriam formas de se defender desse colapso, ao qual o sujeito acredita não ser capaz de sobreviver. Em suas palavras: 
Existem momentos em que se precisa dizer a um paciente que o colapso, do qual o medo lhe destrói a vida, já aconteceu. Trata-se de um fato que se carrega consigo, escondido no inconsciente.[...] Neste contexto especial, o inconsciente quer dizer que a integração do ego não é capaz de abranger algo. O ego é imaturo demais para reunir todos os fenômenos dentro da área da onipotência pessoal. (WINNICOTT, 1963, p.72)

Sabemos que as intrusões que provocam o reagir acontecem sempre, mas, encontramos problemas quando elas ultrapassam a competência integrativa da criança levando a um "transbordamento da para-excitação" - da energia necessária para se defender do excesso que perturba o eu.

A percepção espaço-tempo depende de uma integração do eu. A compartimentação, os elementos dissociados, dispersos e espalhados, dizem respeito a uma não integração. A continuidade leva a um sentimento de existir e à autonomia. Para o autor, o tratamento se daria pela possibilidade de se experimentar, talvez pela primeira vez, o que não teria acontecido na época da infância. Contudo, o medo da desintegração, da perda da identidade, da sua diluição em um mundo sem limites leva o sujeito a acionar seus mecanismos de defesa.

O texto de Lacan sobre o estádio do espelho (1949) influenciou diretamente o pensamento winnicottiano, no entanto, para ele, o psicanalista não teria considerado o espelho em termos do rosto da mãe do modo como ele próprio viria fazê-lo. Assim, de acordo com Winnicott (1975, p.153),

nas primeiras fases do desenvolvimento emocional do bebê humano, um papel vital é desempenhado pelo meio ambiente, que, de fato, o bebê ainda não separou de si mesmo. Gradativamente, a separação entre o não-eu e o eu se efetua, e o ritmo dela varia de acordo com o bebê e com o meio ambiente. As modificações principais realizam-se quanto `a separação da mãe como aspecto ambiental objetivamente percebido. Se ninguém ali está para ser mãe, a tarefa desenvolvimental do bebê torna-se infinitamente complicada.

A função do ambiente envolve o segurar, o manejar e a apresentação de objetos. Winnicott (1975) se pergunta: "Quando o bebê olha para o rosto da mãe ao mamar, o que ele olha ali?" Ele nos diz que,

Para obter a resposta, temos de nos voltar para nossa experiência com pacientes psicanalíticos que podem reportar-se a fenômenos bastante primitivos e, apesar disso, verbalizá-los (quando acham que podem fazê-lo) sem que isso constitua agravo à delicadeza do que é pré- 
verbal, não verbalizado e não-verbalizável, exceto, talvez, na poesia. $(1975$, p.154)

Ele sugere que o que o bebê vê quando olha o rosto da mãe é a si mesmo. "em outros termos, a mãe está olhando para o bebê e aquilo com que ela se parece se acha relacionado com o que ela vê ali" (WINNICOTT, 1975, p.154). Esse seria o curso esperado dos eventos. Para os bebês que olham e não veem a si mesmos, quando a mãe reflete o próprio humor ou a rigidez de suas defesas, há consequências, sendo que a primeira delas envolve a capacidade criativa. Lemos,

A capacidade criativa começa a atrofiar-se e, de uma ou de outra maneira, procuram outros meios de obter algo de si mesmos de volta, a partir do ambiente. [...]Alguns bebês não abandonam inteiramente a esperança e estudam o objeto e fazem tudo o que é possível para ver nele algum significado que ali deveria estar, se apenas pudesse ser sentido. Alguns bebês, tantalizados por esse tipo de relativo fracasso materno, estudam as variáveis feições maternas, numa tentativa de predizer o amor da mãe, exatamente como todos nós estudamos o tempo. O bebê rapidamente aprende a fazer uma previsão: "Por enquanto, posso ficar seguro, esquecer o humor da mãe e ser espontâneo, mas , a qualquer momento, o rosto dela se fixará ou seu humor dominará; minhas próprias necessidades pessoais devem então ser afastadas, pois, de outra maneira, meu eu (self) central poderá ser afrontado". (WINNICOTT, 1975, p.155)

Também nos diz que, na direção da patologia, encontra-se a predizibilidade; quando precária, o bebê é forçado aos limites de sua capacidade de permitir acontecimentos. Isso irá acarretar uma ameaça de caos, o bebê, então, organizará a retirada ou passará a olhar o mundo apenas para poder se defender dele. "Um bebê tratado assim crescerá sentindo dificuldades em relação a espelhos e sobre o que o espelho tem a oferecer. Se o rosto da mãe não reage, então o espelho constitui algo a ser olhado, não a ser examinado" (1975, p. 155).

"O brincar e a realidade" (1975) traz uma série de casos em que Winnicott interpreta a função do rosto tanto em casos clínicos como em artistas. O exemplo privilegiado nesse ensaio é o de Francis Bacon, levando-se em conta que ele na maior parte de seu trabalho, pinta rostos que nos parecem totalmente deformados. Bacon declarava que era fundamental para a apreciação de sua arte que suas pinturas fossem emolduradas em vidro, pois assim, ao contemplá-las, as pessoas não veriam apenas uma pintura, mas poderiam, de fato, ver-se a si mesmos. 
O leitor a essa altura estará pensando em Francis Bacon. Refiro-me aqui, não ao Bacon que disse: 'Um rosto belo é uma recomendação silenciosa' e 'Essa é a melhor parte da beleza, que um quadro não pode exprimir', mas ao exasperador, perito e desafiador artista de nossa época que continua a pintar o rosto humano significantemente deformado. (...) esse Francis Bacon moderno está-se vendo no rosto da mãe, mas com uma peculiaridade nele, ou nela, que enlouquece tanto a ele quanto a nós. Nada conheço da vida particular do artista e o trago à baila apenas porque ele força sua presença em qualquer debate atual sobre o rosto e sobre o eu (self). Os rostos de Bacon parecem-me muito afastados da percepção real; olhando para os rostos, parece-me que ele empreende um penoso esforço no sentido de ser visto, que está na base do olhar criativo. Vejo que vinculo a percepção e percepção, ao postular (no indivíduo) um processo histórico que está na dependência de ser visto: Quando olho sou visto; logo existo. Posso agora me permitir olhar e ver. Olho agora criativamente e sofro a minha a percepção e também percebo. Na verdade, protejo-me de não ver o que ali não está para ser visto (a menos que seja cansado).(WINNICOTT,1975, p.157)

A representação dos objetos possibilita sua ausência, além de manter presente naquele que deles se lembra os elementos que estão relacionados a ele. A representação permite o acesso, mesmo que na fantasia - e de modo limitado - aos benefícios e aos afetos que eram sustentados pelo objeto. Assim, a palavra é vital para a sobrevivência da mãe no sujeito; a mãe só pode "morrer" (desaparecer) sem matar a palavra caso sua vivacidade tenha animado o pequeno em constituição. É preciso que o bebê sinta que ele tem uma existência separada, que seus movimentos articulados ou não, violentos ou amorosos produzem alteração nesse mundo que ainda pode ser precária a separação entre o externo e o interno. É preciso que a mãe não morra psiquicamente, que a vida e sua inexorável transitoriedade não sejam uma ameaça para aquela que deveria garantir ao outro que vale a pena entrar no jogo da vida, no fort $d a$, no vai e volta dos objetos, nas idas e vindas da libido. A brincadeira para o pequeno só será possível se a mãe topa também entrar, propondo a brincadeira sem esperar ser a vencedora ou a melhor, adaptando-se à realidade e a fantasia do bebê, ao seu ritmo e seu descompasso. Entendemos com Winnicott que a neutralização suficiente da pulsão de morte é feita por essa mãe que possui a energia libidinal e o espaço psíquico para incluir um outro que não é ela, mas depende quase exclusivamente dela nos primeiros momentos de vida. 


\section{Capítulo IV . Imóvel tóxico do tempo: melancolia e sublimação em perspectiva}

"Quisera dividir o corpo em heterônimos" - medito aqui no chão,
imóvel tóxico do tempo".

Ana $C$.

A patologia narcísica nos mostra como o sujeito melancólico sabe sobre o tempo e suas regras implacáveis, as quais não podemos escapar. Sua consciência trágica sobre a transitoriedade da vida torna familiar a proposição memento mori (lembre-se da morte). Paralelamente, a imobilidade psíquica produzida é uma tentativa de capturar o objeto do passado no presente para que, assim, o futuro, ou melhor, a partida, se aproxime. Mesmo que este desempenhe o papel de denunciador do poder do tempo, o melancólico tenta se eximir de sua ação através da retirada de seus investimentos na realidade. Esta consciência da verdade produz uma dificuldade ainda maior para o estabelecimento de vínculos afetivos, uma vez que o abandono do objeto já está anunciado para ele em voz alta: análoga àquela do coro, que antecipa o destino do herói grego nas tragédias e conhecendo a tendência melancólica dos artistas, poderíamos perguntar se a obra de arte seria uma forma de realizar essa captura. Como entenderíamos a relação tão estreita que encontramos entre a melancolia e a criação artística? A criação artística é um destino da pulsão capaz de promover laço social, seria então pela via da sublimação que o sujeito melancólico buscaria restaurar sua ligação com o outro e promover o encantamento de seu mundo externo e interno? A fim de responder estes questionamentos, centrais a esta investigação, elencamos esta passagem de Kristeva (1987, pp.5-6), a qual sinaliza um possível caminho:

O passado do melancólico nunca passa. Também não passa o do poeta, o permanente historiado não necessariamente de sua história real como de eventos simbólicos que levaram seu corpo à significação ou, na verdade, aqueles que ameaçam sobrecarregar, transbordar sua consciência. [...] O artista: a testemunha mais intima da melancolia e a mais poderosa lutador contra a abdicação simbólica que o envolve até que a morte venha e o suicídio imponha sua triunfante conclusão sobre o vazio e perda do objeto[...].

Desse modo, compreendemos a partir das proposições da autora que "somente a sublimação resiste à morte" (KRISTEVA, 1989, p.97). No entanto, o que temos tentado demonstrar neste trabalho é uma certa desconfiança no que tange às consequências que a sublimação, entendida no contexto criativo, possa trazer. Como veremos em nossa 
análise de Ana C., esta agiria como um phármacon (CARVALHO, 2003): simultaneamente, nem remédio, nem veneno. Conforme nos indica Carvalho (2003), em A poética do suicídio em Sylvia Plath, o processo criativo em geral e a escrita literária, em particular, se realizam sobre a dupla face remédio/veneno da sublimação, tal qual o "phármacon" descrito por Platão e trabalhado por Derrida (2005) em A farmácia de Platão.

A libido necessária para a criação é a mesma que carrega a história dos caminhos percorridos dentro do aparelho psíquico, junto com suas ligações, fixações, condensações, deslocamentos e desligamentos. O escritor, ao, e para, criar, precisa se aproximar daquilo (das emoções, afetos, intensidades, representações e silêncios) que será transformado, ficando, assim, novamente confrontado com experiências que procuram sentidos e destinos. A criação, como podemos suspeitar, não é sem riscos para aquele que cria, nem para aquele que dela se utiliza. Ela provoca reaberturas que podem ser traumáticas, as quais também podem ser metabolizadas e simbolizadas.

A temporalidade é construída junto à noção de unidade do eu. Mesmo que se queira satisfazer imediatamente os desejos, a percepção do tempo convoca a necessidade de que estes se estendam para um futuro, o que, em si, configura uma relação paradoxal entre ambas categorias. Bianchi (1992) propõe um "trabalho do tempo", o qual seria definido nos seguintes termos:

O trabalho do tempo implica todo um conjunto de renúncias narcísicas que podem ser opostas, termo a termo, aos desejos infantis de sertudo, de ser-por-todo-o-tempo, de ser investido sem obrigação de reciprocidade, de dispor do objeto, etc. A prova de realidade imposta pelo escoar da vida não visa mais diferenciar as manifestações que provêm de "dentro", mas, de maneira mais geral, reconhecer a Lei do tempo - a qual, por mais que atinja o Eu e seu corpo, não deixa de impor-se como uma realidade exterior - livrar da onipotência infantil que volta com tanta facilidade, desde que a vida foge e o narcisismo está ameaçado, onipotência mágica que tende a manter intacto, preservado do tempo e da destruição, este "dentro" que pretende conhecer apenas a lei do prazer (BIANCHI, 1992, p.118).

Kell, por sua vez, em $O$ Tempo e o cão (2009) retoma a noção de "duração" tal qual apresenta Bergson em Matéria e Memória (1990):

Para Bergson, a duração implica a sensação subjetiva de indivisibilidade no movimento de nosso corpo, tanto no espaço quanto no tempo. A duração é uma espécie de ilusão necessária para manter o sentimento de (alguma) continuidade em nossa existência; ilusão, sim, porque se o movimento fosse realmente indivisível, o instante não 
existiria. Mas a duração, medida psicológica da vivência do tempo, não se define pela mera soma de todos os instantes. "Ali onde ritmo do movimento é bastante lento para se ajustar aos hábitos de nossa consciência [...] não sentimos a qualidade percebida decompor-se espontaneamente em estímulos repetidos e sucessivos, ligados entre si por uma continuidade interior? (BERGSON apud KELL, 2009,p.138139)

Levando-se tais considerações supracitadas em conta, surgem questionamentos quanto à peculiar relação do melancólico com o tempo no processo sublimatório. Talvez a fragmentação, como sugere Bianchi, seja uma das características dessa modalidade específica. Lemos:

A fragmentação do sentido que transparece na fragmentação do discurso e dos atos reflete a prevalência da experiência arcaica de descontinuidade oposta àquela, insuficiente, da continuidade - a descontinuidade afetiva, dimensão da perda repetida. A negação do tempo assinala que lhe é, inconscientemente, atribuída qualidade de substrato dos traumatismos, fragmentado ele próprio, tendo perdido o sentido, enquanto portador do irreparável (passado ou por vir).[...]Não vejo que o tempo poderia trazer para mim, a não ser catástrofes (BIANCHI, 1992, p. 116).

Nos lembramos aqui da colocação de Mijolla-Mellor (2010) de que a sublimação está sempre relacionada com o investimento em um tempo futuro. A sublimação seria uma via impossibilitada para o sujeito melancólico ou ela seria uma alternativa de rearranjo subjetivo e de flexibilização dos ideais erigidos? Teremos de considerar que as consequências da sublimação são diferentes para cada sujeito, porém quais seriam os elementos que nos permitiriam mapear os possíveis destinos da desfusão pulsional decorrente deste processo?

Quais os efeitos de uma sublimação estimulada por um ideal todo poderoso - como aquele que é edificado pelo melancólico? Chasseguet-Smirguel (1992) ilumina um pouco essa questão, ao afirmar que,

[...] o processo de criação é unicamente guiado pelo Ideal do Ego, as sublimações não continuando em razão das falhas de identificação, se bem que nós nos achamos diante do paradoxo seguinte: quanto mais os sujeitos sentem dolorosamente o afastamento entre seu Ego e seu Ideal, ou temem a revelação, mais eles serão tentados a utilizar a criação para completar aquilo que eles vivem como uma falha tão mais importante entre seu Ego e seu Ideal (falha ilusoriamente negada às vezes) que eles não puderam integrar valiosamente suas identificações. Estas lacunas em seu Ego, causadas por identificações defeituosas, produzem precisamente uma perturbação na realização de 
sublimações. Sendo então o objetivo da obra o de completar magicamente estas lacunas, resultaria disso que um número considerável de criações - em diversos domínios - obedeceria a uma processo fundamentado sobre o Ideal do Ego sem modificação íntima das pulsões. (CHASSEGUET-SMIRGUEL, 1992, p.93)

Segundo a autora, a sublimação seria afetada pelos modos identificatórios e, paradoxalmente, procuraria reparar as possíveis falhas existentes nesse eu. Sabemos que, na melancolia, a perda do objeto acarretou a perda do próprio eu do sujeito. Algo se passou na história de vida do melancólico que fez com que sua identidade ficasse totalmente dependente de um suporte externo, o que poderia explicar a proximidade que iremos encontrar entre Ana C. e sua obra. Só se existe no olhar do outro, e, na ausência deste, a ferida narcísica que se abre pode não mais se fechar. Quanto maior for o ferimento narcísico, maior será o impulso de repará-lo. Lemos ainda que

O processo de criação por indivíduos propensos, por seu Ideal do Ego, a criar sem sublimação correspondente de suas pulsões, e o processo dos que chegam a uma sublimação adequada, parece-me, não diferirem quanto aos fins buscados. Com efeito, em todos os casos, o ato criado é promovido, a meu ver, pelo desejo (narcísico) de reencontrar a completude perdida e representa, pois, também ele, em certo nível, um meio de chegar aos reencontros do Ego e do Ideal. Quanto mais profunda for a ferida resultante da inadequação entre as aspirações narcísicas e a representação do Ego real, mais imperiosa será a necessidade de ativação dos meios para preencher a fatal lacuna. Logo, se pode daí deduzir que os problemas de identificação ocupam aqui o lugar central. (CHASSEGUETSMIRGUEL, 1992, p. 85)

Essa ideia já foi observada por Abraham (1911/1970), alertando-nos para um limite que, quando ultrapassado, impede o sujeito de criar; portanto, poderíamos entender então, que a sublimação na melancolia envolveria mais riscos este. Em suas palavras,

Antes que se estabeleça o verdadeiro estado de depressão, muitos pacientes apresentam uma energia acima do normal em suas atividades e maneira de vida. Frequentemente sublimam de uma maneira forçada a libido que não podem dirigir para seu verdadeiro propósito. Fazem isso a fim de fechar os olhos para o conflito existente dentro deles e desviar o estado mental depressivo que está tendendo a irromper na conciência. Esta atitude muitas vezes é bem sucedida durante longos períodos, mas nunca o é completamente. A pessoa tem de combater influências perturbadoras durante um longo tempo nunca pode desfrutar de paz ou segurança dentro de si mesma. Qualquer situação que exija uma decisão definida no campo da libido provocará um súbito colapso de seu equilíbrio psíquico, que ele 
manteve tão laboriosamente. Quando o estado de depressão se desencadeia, os seus interesses anteriores (sublimações) cessam de repente e isso conduz a um estreitamento de seu panorama mental, o qual pode tornar-se tão pronunciado a ponto de atingir o monoideísmo. (ABRAHAM, 1911/1970, p.41-42, grifos nossos)

O que o autor nos aponta é que existe uma relação direta entre a sublimação "forçada" e o quadro depressivo que se estabelece depois. Aqui chegamos a um ponto semelhante ao pensamento de Schneider (1990), que reafirma a condição paradoxal, a qual temos perseguido ao longo de nossas considerações:

Só a escritura consola da impossibilidade de escrever. É preciso ir mais longe nos enunciados manifestos pela melancolia. Ou, então, para uma melancolia radical. Se tudo está dito, para que consagrar, depois destas linhas desiludidas, centenas de páginas a dizer ainda? A queixa do melancólico é sua única linguagem. Como se o tudo está dito, ao invés de condenar antecipadamente o projeto literário e de arruinar seu desfecho, formasse sua trama secreta e o recurso último. Como se só se tornasse escritor aquele que deve escrever para calar a certeza de que tudo está dito e para descobrir o que já lá está com um novo dizer; como se estivesse intimado a apagar o escrito demais, o sempre precedente. Talvez só aqueles para quem não existem a amargura de chegar tarde demais e a obsessão de passar sempre ao largo possam dispensar o escrever. Só aqueles se sabem ultrapassados, saturados e invadidos pelo estranho têm o desejo da primeira vez e o gosto do próprio. (SCHNEIDER, 1990, p.421)

Vemos então que é criada uma necessidade de sublimar, de escrever, justamente porque existe algo que precisa ser elaborado, um núcleo de vazio que insiste e ameaça tomar conta do sujeito. A escrita marca tanto a tentativa de elaboração do luto quanto a impossibilidade de realizá-lo. Freud nos diz que, na melancolia, o trabalho do luto não é possível de ser completado, contudo, Lambotte (1997) nos atenta para a necessidade de não a investigarmos apenas como uma pseudoclínica do luto. O que se passa é uma identificação do eu com o objeto e a vontade de se paralisar o tempo. Na antiguidade, a melancolia era associada ao planeta Saturno e o deus Chronos da mitologia grega, deus canibal que engole seus filhos. O melancólico sabe, talvez mais do que ninguém, sobre a transitoriedade da vida: ele está imbuído de uma constante assunção da inevitabilidade das perdas. A vontade, na melancolia, é de sair do tempo, onde as coisas estariam ambas preservadas e mortas. Assim, como pensar o investimento em um tempo futuro para esses sujeitos? Seria através da sublimação que o sofrimento pela iminência da perda poderia se amenizar? A sublimação forçaria ou promoveria a "destacabilidade do 
objeto" que lhes é deficiente, motivo pelo qual não conseguem fazer o trabalho do luto? Ou ainda, seria através do reconhecimento alcançado com a sublimação que a ferida narcísica poderia cicatrizar? O objetivo final de uma análise seria da ordem da sublimação? Seria o luto do ideal todo poderoso o que permitiria que a sublimação na melancolia viesse a reconfigurar a estrutura desse sujeito para formas mais livres e criativas, a "rir de si mesmo"?

De acordo com Kupermann (2010, pp.202-203):

O trabalho humorístico de desidealização impõe-se, portanto, como o avesso do incremento do potencial mortífero do superego promovido pela idealização do objeto, oferecendo-se, efetivamente, como paradigma do processo sublimatório. A guinada promovida pelo dito humorístico do previsível desespero paralisante para a elaboração criadora pode ser ilustrada pelo refrão popular: seria trágico... se não fosse cômico.

Assim nos perguntamos mais uma vez: o que permite a um sujeito fazer humor e a outro ficar petrificado na resignação melancólica? Para Kupermann (2003), o elemento diferenciador também estaria ligado ao modo de identificação. Seria preciso identificarse somente "até certo ponto" com o pai, índice mínimo que mitigaria a força e a tirania do superego.

Mijolla-Mellor (2011, p.47), por sua vez, parece apontar para uma positividade do trabalho de sublimação a partir do momento em que o ideal do eu possa ser relativizado:

O movimento de restabelecimento ou de reconstrução do ego dentro do ego constitui um modelo fecundo que dá conta tanto do luto necessário em relação ao ideal como trabalho que se segue quando o ego pode se propor ao amor do superego lhe dizendo: "Veja, você pode me amar, me pareço de tal forma coma a imagem ideal de ti mesmo que você perdeu..." Mas a diferença de formato vem do fato que não é ele, mas $o$ que ele faz, ou melhor, dizendo $o$ que ele busca nessa aliança, mas que ainda não é possuidor, que o ego se propõe ao superego como objeto de substituição. (Grifos da autora)

Nessa via de entendimento, a possibilidade de reconstrução do eu viria através do luto do ideal todo poderoso, o eu se ofereceria ao superego como uma criança se deixa cuidar pelo pai. Contudo, sabemos que essa negociação feita entre as instâncias psíquicas compromete o eu a ficar numa posição de precário equilíbrio entre as exigências do id, do Superego e da realidade externa. Quando o eu se oferece como objeto de amor para o id (que é a raiz do superego), ele está se colocando contra os 
objetivos da pulsão de vida, como nos diz Freud em "O ego e o id". Destacamos uma importante pergunta para se compreender a escrita de Ana C.: estando o sujeito identificado com o objeto perdido, o que encontraríamos no produto sublimatório seria o eco da voz desse objeto? Ou seria a sublimação que permitiria a elaboração do luto, promovendo uma satisfação libidinal que reconstitui a reserva de libido narcísica? Encontramos esperanças de um destino menos sombrio nas palavras de Schneider (1990, pp.408-409):

\begin{abstract}
Os melancólicos são grandes otimistas. Sob uma constante depreciação do presente e uma rejeição exasperada do passado, eles entretêm a secreta esperança de um futuro verdadeiramente novo. Não conseguem separar as coisas, na parte da desilusão que reconhecem nas coisas a fazer (agenda) uma repetição do irremissível (actum agere), e, na manutenção da palavra, o dizer do já dito. (dictum dicere). O melancólico carrega consigo uma ilusão pela qual não ficou de luto, uma ilusão em oco, a de uma palavra nova em folha, que falaria de um mundo novo em folha, bem verdadeiro, bem meu. (Grifos nossos)
\end{abstract}

Lembramos aqui da busca incessante de Ana C. por uma palavra única. Pensamos que é, então, com o modelo do trabalho de luto e de melancolia que iremos entender as diferentes implicações do processo criativo.

Na sublimação, há o tempo do investimento, do desinvestimento e do reinvestimento. O primeiro é o momento de expansão da energia libidinal para um objeto do mundo externo, isto é, uma resposta, um destino para a força da pulsão que busca em que se satisfazer. Devemos considerar, então, que é preciso haver uma energia inicial, um narcisismo primário para que, depois, por transbordamento da libido, ou uma vontade de expansão (seriam diferentes?), o eu emita seus "pseudópodes" - na metáfora do psiquismo como uma mônoda amebóide - para alcançar este objeto do mundo externo.

Subsequentemente, temos o momento de retirada do investimento feito a tal objeto, uma dessexualização ou desligamento da libido vinculada a ele. É aqui que localizamos o "trabalho de luto", o qual faria uso da potência de desligamento, de desobjetalização da pulsão de morte. Será, portanto, através da pulsão de morte que a energia, antes investida no objeto externo (ou em uma representação, uma ideia), ficará livre e irá se recolher no eu.

É aqui, nessa segunda fase, que acreditamos estar a fonte dos diferentes modos de sublimação. $\mathrm{O}$ que as diferenciaria seriam as maneiras como se processarão o trabalho de luto e o trabalho de melancolia. Entenderemos que, nos dois casos, a energia que 
retorna ao eu traz consigo traços do objeto abandonado, bem como as características do vínculo que se estabelecia com tais objetos.

No entanto, o que percebemos é que a escolha de objeto está diretamente interligada ao tipo de composição subjetiva. A escolha objetal de tipo narcísico revela que o eu precisa de um objeto que o espelhe, que garanta sua existência. A problemática identitária entra em jogo, uma vez que a retirada da libido desses objetos pode incorrer em uma identificação narcísica, típica da melancolia - como vimos anteriormente. $\mathrm{O}$ que se observa é que o trabalho de luto, o qual seria necessário para a próxima etapa do processo sublimatório, ficará comprometido já que desfazer-se do objeto desfacelaria aquilo que garante a unidade do eu. Dessa forma, o dolorido trabalho de luto intensificaria a ferida narcísica ou a fragilidade do eu que precisa de um duplo pra existir. Como ficaria, então, o processo sublimatório quando o trabalho do luto não acontece como esperado (um desligamento gradual do investimento no objeto)?

O segundo momento da sublimação, quando a libido volta ao eu, poderia levar a uma espécie de contaminação ou envenenamento do eu pela pulsão de morte que é liberada pelo próprio processo. Se a libido que mantém a unidade do eu possui pouco poder de resistência, a interferência da pulsão de morte poderia fragilizar ainda mais os elementos que o compõem, fazendo com que outros mecanismos defensivos capazes de evitar ou conter a despersonalização e a desintegração do eu sejam necessários. Como sabemos, a identificação narcísica é um desses mecanismos, trazendo para o interior do eu o objeto ao qual deveria ter-se desvinculado. As consequências dessa problemática irão aparecer no terceiro momento da sublimação, o reinvestimento libidinal a um outro objeto destituído de seu caráter sexual (embora saibamos que ele está relacionado ao primeiro), objeto compartilhável com os outros membros da cultura. No último tempo da sublimação a problemática da fusão, desfusão e refusão pulsional, bem como a identificação e desidentificação ocupam a centralidade da discussão. Mesmo quando o trabalho de luto é bem realizado iremos perceber a influência do objeto que foi sublimado. A sublimação aqui seguiria o modelo do sonho e seus processos primário e secundário, onde veríamos a deformação, o disfarce e o tratamento estético daquilo que irá reaparecer então transformado, burlando a censura. Agora, quando o "trabalho de melancolia" se faz necessário, pensamos que a criação ou a transformação presente no processo criativo se mantenha muito mais próxima desse objeto identificado narcisicamente ao eu. A criação, nesses casos, teria uma função importante de espelhamento, de suporte identitário, de composição de subjetividade. Talvez nos 
aproximemos aqui do que Klein (1940) entendia como sublimação, ou seja, ela estaria ao lado das reparações que o eu faz ao objeto de amor, sempre ambivalente.

Acreditamos que alguns tipos de sublimação deixam o ego mais exposto ao trabalho de pulsão de morte. O que permitiria ou não uma refusão pulsional fora da ordem do masoquismo seria o "tempo de elaboração" do processo sublimatório. A especificidade da sublimação na melancolia está referida à intensidade de investimento no objeto. $\mathrm{O}$ eu melancólico, contaminado pela "bílis negra”, não pode se privar do prazer encontrado no investimento narcísico ao objeto. Novas identificações narcísicas seriam precipitadas pela necessidade de recolher para si o máximo de libido para contrapor aquela que se esvai. Na melancolia, o trabalho do luto necessário à sublimação fíca suspenso no tempo, uma vez que o sujeito entra em conflito entre abrir mão do objeto investido em função de outro investimento que poderia ser prazeroso, o qual, porém, é percebido como uma nova possibilidade de abandono. Pontalis (1991, p.143) nos fala sobre os efeitos da separação do objeto:

\begin{abstract}
Separar-se, desunir-se do objeto e de si, desligar-se do semelhante ao idêntico, medir incessantemente a distancia entre a coisa possuída e a palavra que a designa, e que ao designá-la diz de imediato que ela não está ali. Dessa distancia, por sua vez, tentamos fazer uma coisa. Procuramos provas de que ela poderia, de que deveria não ter-se produzido, de que nos fez sofrer um prejuízo que não temos como tolerar. Queixamo-nos de todas as separações de que fomos vitimas. Não nos cansamos de fixá-las no tempo: uma partida, uma morte, uma negligencia - tantos abandonos, outras tantas ofensas. Conferíamolhes uma imagem e um lugar: uma casa imóvel de seus odores, que já não existem; um olhar de mãe que se voltou para outro lugar (pior: para dentro dela mesma, onde não estávamos); um nadinha qualquer que, para nós, era tudo de que precisávamos.
\end{abstract}

Sabemos que a representação está sempre deslocada do real em diversos níveis, impostura que o melancólico denuncia; não se pode enganar uma demanda através de uma presença que não está lá - a alucinação. A fragilidade da constituição desses sujeitos nos leva a pensar que num primeiro momento a sublimação pode funcionar como um remédio para a dor de existir. Entretanto, são trazidos à tona, através da sublimação, tanto conteúdos da memória que são representação, quanto aqueles que se mantiveram apenas como percepção, como "representação-coisa". Conteúdos recalcados emergem no processo sublimatório, o que, além de obrigar o sujeito a se confrontar com esses conteúdos que podem ser disruptivos, ajudam a somar a quantidade de elementos iatrogênicos a ele. Vemos o contorno de um modo masoquista 
de composição subjetiva, que encontrou uma saída através da inversão da economia psíquica que esperaríamos encontrar, evitar o desprazer e a dor e buscar a satisfação. Como seria possível promover a reinversão desse quadro?

De acordo com Freud (1924, p. 200),

$\mathrm{O}$ prazer e o desprazer, portanto, não podem ser referidos a um aumento ou diminuição de uma quantidade (que descrevemos como 'tensão devida a estímulo'), embora obviamente muito tenham a ver com esse fator. Parece que eles dependem, não desse fator quantitativo, mas de alguma característica dele que só podemos descrever como qualitativa. Se pudéssemos dizer o que é essa característica qualitativa, estaríamos muito mais avançados em psicologia. Talvez seja o ritmo, a sequência temporal de mudanças, elevações e quedas na quantidade de estímulo. Não sabemos. (Grifos nossos)

Uma das variáveis importantes para observarmos o que compõe essa economia psíquica, a qualidade estética que Freud suspeita estar envolvida na fusão e desfusão, é o tempo de resposta do objeto (ambiente) aos apelos do pequeno sujeito. É a constatação da morte que gera a noção de temporalidade e, para saber-se vivo, é preciso que um outro ofereça cuidados, um espaço psíquico, uma voz e um olhar capaz de reconhecer no corpo que pode ser apenas carne, um sujeito.

Freud (1950[1895]), ao propor a ideia de uma primeira experiência de satisfação, já inclui o tempo nessa dinâmica psíquica. Retomemos, por exemplo, a primeira mamada mítica: ela seria um ponto de partida, a primeira experiência que imprime traços e ranhuras no aparelho psíquico. O apaziguamento da fome e do desconforto provocado pelas necessidades vitais básicas produz uma marca, um prazer, que será buscado incessantemente. $\mathrm{O}$ tempo entre a primeira mamada e o retorno da fome leva o pequeno sujeito a buscar as primeiras impressões daquilo que trouxe saciedade, alívio, nutrição, conforto - o que propiciou uma descarga da excitação que é seguida de prazer (no modelo da primeira tópica). A experiência de satisfação com o objeto que ainda não se sabe externo ou interno reaparecerá sob a forma de uma "alucinação". Essa seria a tentativa arcaica de representação do objeto que deveria retornar e atender às exigências do recém-nascido. Para Winnicott (1994), esse momento compõe o cuidado da mãe suficientemente boa, que irá buscar adequar-se aos ritmos e "especificidades" do bebê de modo a satisfazê-lo, mas deve também ser capaz de suportar sua angústia, a sua frustração e a de seu filho, oferecendo recursos psíquicos (nomeação, cuidado, pensamento, metabolismo das emoções) que permitem que o psiquismo em formação 
seja colocado em marcha pela necessidade de representação das experiências, para que, aos poucos, ele possa interagir com o ambiente e se comunicar com ele.

Convocamos aqui a noção winnicottiana da experiência de ilusão-desilusão, em que o objeto é, ao mesmo tempo, criado e encontrado: esta alucinação que busca recriar o objeto de satisfação deveria ser logo acompanhada pela apresentação do mesmo (no caso do bebê, o seio) pela mãe, reforçando no bebê a sensação de existência no mundo. Nessa primeira tentativa de sublimação, o objeto que fez a sua marca - que traçou caminhos de "facilitação" - será relembrado, mas a recuperação dessa "memória" implica necessariamente uma transformação e uma perda. Segundo Freud (1950[1895]), o objeto é na verdade reencontrado, uma vez que a busca que teria o poder de apaziguar todas as dores, é o que move o desejo, faz decolar o psiquismo. Com Rosenberg (2003) entendemos que quando o objeto que nutre, que criou uma certa constância e expectativa no bebê, falha, vemos aparecer uma "masoquismo guardião de vida" como forma de tornar suportável o desprazer (que deveria ser apenas temporário) trazido pela frustração. A capacidade de adiamento, de substituição, de renúncia à satisfação imediata é fundamental para a constituição psíquica. Como vimos, a investida da pulsão de vida no momento de desprazer permitiria o adiamento traria uma capacidade de suportar o tempo que levará para o objeto retornar - no modelo proposto, a próxima mamada.

Contudo, entendemos que haveria um "tempo ótimo", um ritmo próprio a cada indivíduo que determinaria suas singulares necessidades - sendo esta a chave de entendimento necessária à função da mãe suficientemente boa, que não sabem que protegem o filho de seu próprio inconsciente. A tarefa da maternagem é mais complexa do que pode a princípio parecer, a ansiedade de uma performance perfeita pode distanciá-la de suas emoções contraditórias, o que pode produzir formações reativas que comprometerão a capacidade de introjeção do bebê. De acordo com Mannonni (1992, p.202),

A mãe ansiosa tem por modelo a "boa mãe", modelo impossível de atingir, e com toda razão: pois o que é uma boa mãe? Em todo caso é uma mãe que jamais tem sentimentos hostis para com os filho. $\mathrm{Na}$ mãe idealizante, é o filho que receberá a carga esmagadora de assemelhar-se ao filho modelo. [...] A mãe idealizante, sempre decepcionada, vê-se obrigada a sentir que odeia seu filho e a entrever o desejo de morte, o que a coloca em luta contínua consigo mesma [...]. 
Queremos colocar em relevo o intervalo entre o surgimento da necessidade e o aparecimento do objeto (a mãe), localizando aí a capacidade de esperança e, consequentemente, de desesperança, elementos centrais na vida do sujeito.

Quando pensamos com Winnicott (1975) que o espaço transicional seria o lugar onde se processa o criar, uma perturbação desse espaço incidiria diretamente sobre o ato de criação. Pensamos que algumas qualidades do processo criativo são determinadas pelas primeiras experiências com os objetos. Kupermann (2008) ressalta uma dimensão do criar que necessita, sempre, de uma energia destrutiva, da agressividade para desfazer os modelos rígidos previamente determinados e poder, então, fazer outra coisa com esses elementos, esses fragmentos. A pulsão de morte seria essa energia destruidora fundamental para a transformação do objeto, da matéria. O processo criativo poderia então operar dentro de um espaço que seria mais ou menos expandido. Primeiro o sujeito deveria ter confiança suficiente no mundo externo que o permita destruí-lo para que depois ele seja reconstruído em outros moldes (em palavra, linguagem). Contudo, o reinvestimento libidinal daquilo que ficou fragmentado precisa dar-se também pelo modelo da mencionada temporalidade envolvida na satisfação trazida pelo objeto cuidador.

A mencionada alucinação, a imaginação que recria o objeto perdido é seguida pelo desprazer da urgência advinda da necessidade. O "masoquismo de vida" aparece em auxílio ao eu para que seja possível suportar o desprazer. Contudo, se o objeto não aparece, o tempo entre a urgência e a satisfação ultrapassa os recursos sublimatórios do sujeito. A consequência desse desencontro é a desesperança - uma das marcas da pulsão de morte -, a descrença de que o objeto irá retornar. Tragicamente, como último recurso psíquico - se ainda podemos considerá-la como recurso -, a desesperança surge para garantir que o sujeito não se frustre tanto de uma próxima vez. É a certeza de que alguém virá que permite ao sujeito expandir cada vez mais esse espaço transicional que é criado entre o mundo interno e o mundo externo. Winnicott sugere que o padrão dos fenômenos transicionais começam a surgir por volta dos quatro meses e duram até cerca do primeiro ano de vida. Sobre eles Winnicott (1975, p.14) nos diz

Introduzi os termos 'objetos transicionais' e 'fenômenos transicionais' para designar a área intermediária de experiência, entre o polegar e o ursinho, entre o erotismo oral e a verdadeira relação de objeto, entre a criatividade primária e a projeção do que já foi introjetado, entro o desconhecimento primário de dívida e o reconhecimento desta. 
O espaço transicional permite a expansão dos recursos psíquicos que protegem o sujeito da "dureza" e concretude do mundo externo, como a fantasia, a criatividade e a imaginação. Contudo, vemos que esse mundo é também o princípio de realidade que retira o sujeito de suas fantasias e pensamentos extremamente aterrorizantes e angustiantes. A desesperança, pensamos, neutralizaria a fertilidade do momento alucinatório anterior, fazendo com que, progressivamente, o pensamento e os modos de relação com os objetos sejam cada vez mais concretos, sem possibilidade de relativização, retradução ou elaboração.

No lugar da alegria descuidada da criança, vemos a possibilidade da invasão da pulsão de morte que irá intensificar a voz tirânica do superego, contaminar e desfazer os elos narrativos construídos com as representações. Se tomarmos o exemplo do humor para compreender o mecanismo dinâmico do conflito que ora buscamos descrever, vemos, como ressalta Kupermann (2003), que a função do superego pode ser radicalmente outra da que costumamos fazer referência. $\mathrm{O}$ superego trata o eu como uma criança que precisa de acolhimento e as coisas que pareciam penosas ou vexatórias trivializam-se. Talvez o que observamos no humor seja o exemplo do que o mecanismo maníaco busca alcançar, uma supressão da força tirânica do superego e uma recomposição do ego que foi tão diminuído, fragmentado, esvaziado.

Se o objetivo de Eros é estabelecer sempre maiores unidades, o fragmento seria, então, tributário da pulsão de morte. "Eros estabelece unidades que lhe sirvam como elementos ainda "maiores" unidades em um movimento integrador que implica uma temporalidade, já que é "sempre" renovado". (ROSENBERG, 2003, p.181)

Mas se o objetivo final da pulsão de morte é a destruição da vida, também é verdade que esse objetivo só pode ser realizado através da desconstrução e da quebra das relações entre as unidades construídas pela pulsão de vida. A desconstrução de uma unidade faz com que encontremos os elementos-unidades que a constituíam e iremos observar que os dois movimentos, o progressivo e o regressivo, só podem ser realizados com a participação das duas pulsões, juntamente com a intrincação pulsional que é sempre presente, necessária.

A estética fragmentária é uma das características marcantes da poesia de Ana C. e também a encontramos num dos primeiros poetas modernos, Baudelaire, que é citado e traduzido por Ana C. A noção de alegoria que aparece em sua poesia parece ser uma figura capaz de traduzir a relação do melancólico com a palavra. O filósofo Benjamin, 
em seu trabalho sobre o barroco alemão - estética que realizaria ao máximo a tensão melancólica - expõe as implicações do apelo alegórico:

esta é justamente a essência da profunda meditação melancólica: seus objetos últimos, onde ela acredita, de forma mais total, assegurar-se do mundo depravado, transformando-se em alegoria, preenchem e negam o nada no qual se apresentam, da mesma forma que, no fim, a intenção não se mobiliza na contemplação fiel das ossadas, mas volta, infiel, para a ressurreição. (BENJAMIN apud KRISTEVA,1987)

Vemos nessa figura, novamente, o negativismo melancólico descrito por Lambotte (1997) e a impossibilidade do luto. Acreditamos que a análise feita por Kell (2009) sobre Baudelaire está em sintonia com a que fazemos de Ana C.. De acordo com ela:

Por meio do recuo poético à alegoria, que evoca os fragmentos do objeto perdido não pelo uso da metáfora, mas da metonímia, o poeta aborda a dor provocada pela passagem do tempo. A passagem voraz do tempo é presença constante na poesia de Baudelaire. [...]A observação freudiana conduz a uma pergunta em relação ao projeto estético de Baudelaire: teria ele escolhido a alegoria como forma predominante de expressão poética por razões formais, ou sua compulsão simbolizadora ("tout pour moi deviant allégorie") pode ser considerada como tentativa de cura para o vazio depressivo em que o poeta já estava, de antemão, instalado? A pergunta, embora irrespondível, merece ser formulada: a melancolia teria sido, em Baudelaire, o motor de sua estratégia poética ou o custo subjetivo de seu projeto estético de dar conta da modernidade por meio da emancipação frente as vivências, e consequentemente da destruição do imaginário? (KELL, 2009, p.184-185, grifos nossos)

Sabemos que o próprio poeta Baudelaire se considerava um melancólico e acreditamos que seu fazer poético não está desvinculado dessa sua condição. Fazemos coro à pergunta já feita por Carvalho (2003) e agora por Kell (2009) como o projeto estético do artista interfere no seu psiquismo? Novamente, Kell nos ajuda a pensar essa questão:

Usar o símbolo no lugar em que deveriam estar as representações de coisas: seria o caso de perguntar se, para esses depressivos que se protegem do vazio ao se interessar por grandes estruturas simbólicas, tudo também se torna alegoria. No caso de Baudelaire, a poesia foi o terreno do predomínio do simbólico sobre as formações do imaginário. O risco de tal empreitada não é estético: é psíquico. (KELL, 2009, pp.184-185, grifos nossos) 
Aqui reconhecemos a lógica circular, que sai da tentativa de representação do objeto para o encontro do objeto na palavra enquanto coisa. Este risco psíquico pode ser também exposto nos seguintes termos, como nos aponta Rosenberg (2003, p. 188): “Quanto mais pulsão de vida é gasta defensivamente para opor-se à desconstrução e à regressão vindas da pulsão de morte, menos ela é capaz de construção, de síntese e de inovação". Lembremos que as duas classes de pulsão são conservadoras, mas "quanto mais a definição de pulsões se distancia do modelo dos instintos, mais as pulsões adquirem um valor historicizante, isto é, de exigência incontornável de historicidade dirigida à vida psíquica" (ROSENBERG, 2003, p. 185). De acordo com Freud, a ligação é o objetivo de Eros, isto é, estabelecer sempre maiores unidades:

Uma das diferenças fundamentais entre as duas pulsões com relação ao seu caráter conservador realiza-se na identidade do passado conservado: quanto à pulsão de morte, trata-se de restabelecer um estado anterior, um passado, idêntico àquele que existia, pela destruição de tudo o que aconteceu posteriormente; no que se refere à pulsão de vida, trata-se de conservar o passado integrando-os nas organizações - unidades mais amplas, mesmo que essa integração só possa acontecer à custa de certa transformação. Para a pulsão de vida, a conservação do passado só pode se dar, portanto, por um movimento integrador que é um passo adiante, uma expansão da vida que está na natureza de Eros [...] (ROSENBERG, 2003,p.183)

Assim, na pulsão de vida há uma remanescência do passado no presente. A pulsão de morte também representa uma tendência do passado em reinstaurar-se, isto é, ele acrescenta a essa remanescência do passado uma espécie de resistência ativa que o passado opõe ao seu desaparecimento.

Uma intrincação pulsional relativamente bem-sucedida torna assim ativa e indestrutível a remanescência no presente. Podemos imaginar que sem a pulsão de morte a potencialidade de ligação da pulsão de vida teria a tendência não somente de transformar o passado, mas de apagá-lo, reconduzindo assim a historicidade da vida psíquica a uma mudança de "presentes" puros e descontínuos, o que equivaleria a uma anulação de seu valor historicizante (ROSENBERG, 2003, p. 184).

O panorama que se apresenta nos mostra a dificuldade da realização do trabalho de melancolia, da mudança do tipo de investimento, que poderia ser entendida também como um movimento progressivo, que pode enfim perceber o outro objeto como total. Na segunda teoria pulsional Freud entende que a regressão é correlativa à desintrincação pulsional. Em “O ego e o id” (1923) Freud diz: 
Para generalizar rapidamente, poderíamos supor que o sentido de uma regressão da libido, por exemplo, da fase genital à fase anal, repousa sobre uma desunião pulsional, e que, inversamente, o progresso da primeira fase genital à fase genital definitiva tem como condição um aporte de componentes eróticos.

De acordo com Rosenberg, "se há uma fixação ao objeto é para impedir uma desintrincação pulsional e, com ela, como vimos, uma regressão mais profunda". (ROSENBERG, 2003, p.191) Aqui entenderíamos a relação de proximidade na melancolia com o objeto primário que é fonte da dor psíquica. Ater-se a esse objeto fixação ao objeto e também ao modo de relação de objeto ( no caso da melancolia, oral canibalista) - conservando-o no objeto sublimado, talvez seja ainda uma forma de evitar uma desintrincação maior, essa regressão mais profunda. Segundo ele,

[...] o progresso de uma fase a outra está ligado a "um aporte de componentes eróticos". [...] mas vimos que, esse aporte de Eros-libido não é o mesmo, dependendo de se impede a regressão ou se favorece a passagem de uma fase à outra: isso acontece na economia interna da pulsão de vida, na dialética interna entre Eros como (auto) conservador ou Eros-libido, fazendo progredir nossas relações objetais. [...] essa economia interna da pulsão de vida, que faz prevalecer ou a característica anti-regressiva ou ainda a característica progressiva do sentido pulsional das organizações psíquicas depende, por sua vez, da economia da intrincação pulsional, isto é, da força respectiva, em um dado momento, da pulsão de vida e da pulsão de morte uma em relação à outra. (ROSENBERG, 2003, p.191-192)

Nos deparamos novamente com o limite da sublimação, limites que são impostos pela relação dinâmica e econômica da fusão e desfusão pulsional.

Sabemos o que acontece quando investimentos demasiado maciços absorvem a libido que se dirige ao objeto e esvaziam perigosamente o eu de uma libido narcisista de que ele tem necessidade para se defender dos ataques do interior; sabemos também o que acontece no retorno maciço da pulsão de destruição do exterior, como na melancolia. Essa condição paradoxal poderia ser traduzida por esta fórmula: o ser humano só existe se consegue desviar suas pulsões de seus alvos, ao menos em grande parte. É muito improvável que ele possa existir se tiver demasiado sucesso nessa tarefa. (ROSENBERG, 2003, p.202)

Nessas patologias em que a violência e a morte espreitam, a identidade do eu está ameaçada, por essa razão, seria falso dizer que é o eu que desvia uma parte da pulsão de morte. $\mathrm{O}$ eu é ele mesmo o resultado de uma intrincação pulsional que irá condicionar sua existência, como vimos em "O problema econômico do masoquismo" (1924), Freud 
fala da união pulsional antes de falar do eu. (Cf: ROSENBERG, 2003, p.201) Iremos então pensar com o autor: "Podemos colocar a questão de saber se a vitória final da pulsão de morte não é o esgotamento dessa capacidade do eu, de desviar em proveito próprio uma parte da pulsão de morte”. (ROSENBERG, 2003, p.200) Talvez o autor esteja dizendo que, a vitória da pulsão de morte é a ausência da capacidade sublimatória.

Tomaremos a análise que Freud fez do escritor Dostoievski para investigar um pouco mais o entrelaçamento da sublimação e pulsão de morte, para que, assim, possamos passar para a análise da relação entre a escrita e a subjetividade no caso particular da poeta Ana Cristina César. 


\subsection{Sobre Dostoievski, a culpa e a escrita.}

Freud (1928[1927]), em sua análise sobre Dostoievski, nos mostra a relação complicada do escritor com o jogo e a humilhação. O romancista, aparentemente, só escrevia após perder tudo no jogo, quando parecia não haver mais saída. Ele implorava a sua esposa para que o desprezasse, sendo que o "jogo era para ele um meio de castigar a si mesmo." (FREUD, 1928[1927], p.220) Sua companheira percebia a existência de um ciclo que se repetia, ela observara que a produção literária, somente o que podia salvá-los da pobreza, não se realizava nunca com tanta naturalidade do que quando tinham perdido tudo e entregado suas últimas economias ao credor.

Naturalmente, ela não compreendia a conexão. Quando o sentimento de culpa dele ficava satisfeito pelos castigos que se havia infligido, a inibição incidente sobre seu trabalho se tornava menos grave e ele se permitia dar alguns passos ao longo da estrada do sucesso (FREUD, 1928[1927], p.220).

Para Freud, uma vez a culpa apaziguada, a satisfação pode sucedê-la, isto é, após castigar-se no jogo a libido estaria livre para a satisfação através do processo sublimatório da escrita. Mas nos perguntamos aqui, satisfação de qual instância? Do eu, do id, ou do supereu?

Rosenberg (2003) pergunta se seria o masoquismo moral que tornaria possível a criação nesse escritor. O apaziguamento da culpa seria sempre masoquista, assim, algumas pessoas só suportariam sua culpa se em certos momentos de sua vida fosse possível um investimento masoquista que o permitiria suportá-la e apaziguá-la.

No "ciclo do jogo" de Dostoiévski, tivemos uma primeira fase em que a satisfação do jogo e a culpa se seguem e são indistintas; uma segunda fase de masoquismo moral na qual a satisfação é culpa erotizada, e isso provavelmente porque a culpa é demasiado intensa para ser suportada, a não ser que investida masoquistamente; uma terceira fase, enfim, onde a culpa é seguida pela satisfação sublimatória (ROSENBERG, 2003, p.47).

O caminho da agressividade dentro do aparelho psíquico talvez encontre na "satisfação sublimatória" um outro modo de atuação mais sutil, clandestino, e também mais mortífero. Clandestino porque fora da lei do princípio do prazer: evitar a dor e buscar o prazer. Em Dostoievski, o masoquismo moral parece ser inerente ao processo 
criativo. A curiosa dinâmica observada nos mostra que a criação só lhe era possível na miséria. Será que os castigos - entre eles o jogo e a miséria - pagavam a dívida do eu para com o Superego, permitindo a ligação da energia de morte através do masoquismo deixando novamente livre a energia para a criação, para o investimento em outros objetos? A escrita para Dostoievski seria o final do ciclo ou ainda faria parte deste jogo mortífero e silencioso que estaria operando no interior de seu psiquismo? Isto é, os ataques do superego, reforçados pela desfusão pulsional resultante da sublimação promoveriam uma destruição lenta e subreptícia de seu mundo interno? Assim, as palavras que ganhariam liberdade e seriam transformadas a partir dos conteúdos psíquicos disponíveis ao escritor iriam aos poucos se aproximando do ponto do indizível, onde a palavra encontra seu limite representacional, a palavra vira também uma coisa com a qual ele joga. O jogo pelo jogo, o texto pelo texto, no final, talvez, fossem a máxima punição - o (re)encontro com o não sentido, realizando, assim, o objetivo da pulsão de morte.

A sublimação aparece como uma das primeiras saídas que nos vem à mente para a necessária "objetificação" que deveria ser produzida pelo trabalho de melancolia. Contudo, vemos com Green (1983/1990, p. 258) que o objeto artístico também pode ser investido narcisicamente: [...] não há então nada de surpreendente em podermos encontrar no âmago da sublimação um objeto narcisista que se referiria pois, ao sublime tal qual o eu o experimenta para o seu próprio prazer [...] Talvez por isso a escrita funcione nesse limite tênue entre aquilo que pode curar e o que pode ferir, envenenar. A palavra estará investida de modo distinto na melancolia:

\begin{abstract}
a melancolia termina seu curso após certo lapso de tempo sem deixar atrás de si alterações aparentes e grosseiras, caráter que partilha com o luto. Neste, sabemos que o tempo era necessário para que fosse executado em detalhe o comando da prova de realidade, trabalho após o qual o eu pode liberar sua libido do objeto perdido. Podemos pensar que a palavra está ocupada, durante a melancolia, por um trabalho análogo; em ambos os casos, o processo escapa, do ponto de vista econômico, a nossa compreensão (ROSENBERG, 2003, p.126).
\end{abstract}

Do ponto de vista topológico, temos que nos perguntar entre quais sistemas psíquicos acontece o trabalho de melancolia. Freud (1917[1915]/2010, p.190) pergunta: “dos processos psíquicos dessa afecção, o que ainda se passa relacionado aos investimentos objetais inconscientes abandonados, e o que relacionado a seu substituto por identificação, dentro do eu?". Para ele, a resposta fácil e rápida seria 
que a "representação inconsciente (da coisa) do objeto é abandonada pela libido". Mas na realidade essa representação é constituída de inúmeras impressões singulares (traços inconscientes delas) e a execução dessa retirada da libido não pode ser um evento momentâneo, e sim, como no luto, um processo demorado, de lento progresso. É difícil dizer se começa em muitos lugares ao mesmo tempo ou se comporta alguma sequência determinada; nas análises pode-se frequentemente verificar que ora esta, ora aquela recordação é ativada, e que as queixas sempre iguais, fatigantes em sua monotonia, têm origem numa fundamentação inconsciente, diferente a cada vez. Se o objeto não tem para o Eu uma grande significação, reforçada por mil nexos, então sua perda não é capaz de produzir luto ou melancolia. Portanto, a característica de executar passo a passo o desligamento da libido deve ser atribuída igualmente ao luto e à melancolia, baseia-se provavelmente na mesma situação econômica e serve às mesmas tendências. (FREUD, 1917[1915]/2010, p.191).

Somente quando um objeto possui um grande valor afetivo é que as manobras melancólicas fazem de tudo para evitar a sua perda. A desafetação e a anestesia, as quais muitas vezes caracterizam a afecção, se contrapõem à intensidade dos sentimentos nutridos pelo objeto amoroso. Por isso, até mesmo a retirada da libido da representação inconsciente do objeto está comprometida.

Exercitando os conceitos e dinâmicas discutidos até esse momento do trabalho, nos dedicaremos agora à obra de Ana Cristina César. 


\section{Capítulo V - No entre-lugar do eu: a obra de Ana Cristina César}

\subsection{No interior da palavra}

Uma frase em cada linha. Um golpe de exercício. Memórias de Copacabana. Santa Clara às três da tarde. Autobiografia. Não, biografia. (CÉSAR,1982/1992, p.7)

Prosa, poesia, confissão ou escritura do eu? Não, biografia. Aqui, nossa preocupação será pensar, através da sublimação, nos graus variados de proximidade com o que chamamos de fonte pulsional. Contudo, não pretendemos afirmar o que seria necessário para que o mergulho nas letras não seja um naufrágio. Inicialmente, acreditamos na importância da contraposição, a qual elenca, de um lado, o diário, os cadernos terapêuticos e a adução técnica, e, de outro, a poesia, e a tradução literária. No entanto, tais limites parecem ser quebrados e Ana C. transforma tudo em ficção. Quanto aos temas e motivos que percorrem sua poética estão o silêncio, a morte, o mar e o nada. Ao lermos a poeta, temos a impressão de que seria possível reconstituir os passos que marcaram toda sua trajetória, culminando em seu suicídio. Em um texto publicado um ano após a morte de Ana C. sua, por exemplo, Heloisa Buarque de Hollanda (1984/2013, p.451), sua amiga e mentora, escreve: "Enterneço-me com a amiga, embaraço-me com a obra que, agora, desdobra-se em recorrentes bilhetes, avisos, sinais. Sofro com a descoberta de uma anotação escrita no hospital pouco antes de sua morte: estou sirgando, mas o velame foge". Desse modo, compreendemos, à luz de Sontag (apud. VIEGAS, 1998, p.41), que "não se pode interpretar a obra a partir da vida, mas pode-se, a partir da obra, interpretar a vida".

A estreia literária de Ana C. aconteceu muito cedo: aos 7 anos teve suas primeiras poesias publicadas no "Suplemento Literário" de um jornal carioca. Qual teria sido o efeito dessa relação tão íntima e intensa com a palavra escrita desde os primeiros anos de vida? A partir da biografia podemos identificar que a poesia é o modelo privilegiado de comunicação com sua mãe, o que se reproduzirá em seu estilo de escrita, na multiplicidade de vozes que parecem buscar uma conversa ao longo de seus versos. Seu 
biógrafo, Moriconi, nos diz que, no início, a poesia era arte ouvida, como aquela, de cunho religioso, lida e contada na igreja que sua família frequentava. Segundo ele,

ditava seus poemas à mãe, que os punha em forma caligráfica. A mão da mãe era o veículo pelo qual Ana podia expressar-se.[...] Adulta, repetia sem cessar o movimento de escrever, como um tique nervoso. Gesto de escrever com mão vazia, fechada sobre si mesma como se empunhasse o lápis, percorrendo a superfície que estivesse mais próxima, mesa de bar, espaldar da cadeira, as próprias pernas. (MORICONI, 1996, p.75)

Sua identidade de poeta a deixava em conflito, como se estivesse presa a ela e não pudesse escapar. Em um poema de 68, aos 16 anos, Ana $\mathrm{C}$ escreve:

Neste interlúnio

Sou um dilúvio ou me afogo.

[...]

Neste interlúnio

Sou fagulha ou hulha inerte

Enorme berne entra corpo adentro,

Poetas quietos entreolhando

Coisas coisas que falecem

Neste interlúnio,

Sou coisa ou poeta. $\quad$ (CÉSAR,1998,p.32)

Moriconi (1996) confirma nossa impressão de que a literatura havia se tornado um objeto ambivalente para Ana C., o qual, ao mesmo tempo, a movia e aprisionava. Ele diz:

Mas o fato é que viveria sempre, até morrer, o conflito entre o tesão por uma vida literária mais próxima ou inteiramente mergulhada no ritmo nervoso dos jornais e da profissionalização editorial. Quando estava na universidade, sonhava sair dela. Quando estava fora, queria voltar. (MORICONI,1996, p.26)

Nossa expectativa era encontrar uma implicação diferente no investimento de cada modalidade de escrita, mas vemos que no processo de composição da maioria deles, há uma exigência extrema de perfeição e um grande pavor do fracasso. Ainda nas palavras do biógrafo:

Redigia seus artigos após longos períodos de fermentação e estudos desproporcionalmente prolongados diante do tamanho e do nível de exigência efetivamente esperado deles. Mas isso mostra a importância que consumiam para a autora. E o grau de exigência que se colocava a 
si própria. Vivia atormentada pelo senso de responsabilidade. A cada tarefa intelectual com que se defrontava, apavorava-se com a possibilidade do fracasso (MORICONI, 1996, p. 27).

Os dois períodos que esteve na Inglaterra foram de intensa produção. A primeira viagem em 1969-70 tratou-se de um intercâmbio pelo Rotary, e, a segunda, em 1979-80, teve como motivo um mestrado sobre teoria e prática de tradução literária. Na correspondência que mantinha com amigos no Brasil, temos notícia do que estava lendo, os filmes aos quais assistia e os relacionamentos que mantinha. É nesse período que produz um caderno de escritos e desenhos, na tentativa de, talvez, "sair da pauta", como diz ela. Percebemos ali uma forte ligação entre os temas de suas cartas, poemas e tradução. Suas aventuras amorosas, as descobertas acadêmicas, a melancolia e a solidão dão o tom de seus escritos. Lemos:

Fico quieta.

Não escrevo mais. Estou desenhando numa vila que não me pertence.

Não penso na partida. Meus garranchos são hoje e se acabaram.

Perdi um trem. Não consigo contar a história completa.[...]

Eu não sei focar ali no jardim, sobre a linha do seu rosto, mesmo que seja por displicência estudada, a mulher difícil que não se abandona para trás, para trás, palavras escapando, sem nada que volte e retoque e complete.

Explico mais ainda: falar não me tira da pauta;

Vou passar a desenhar; para sair da pauta

(CÉSAR,1980, p.95)

Em uma carta para Clara Alvim, Ana menciona como seus pais foram brilhantes na infância e criaram os filhos com grandes expectativas, utilizando-se também da figura do cais, a qual se repete inúmeras vezes em sua obra:

[...] Estou percebendo agora que sou briguenta, faço birras, apostas, leilões... Percebo e continuo a querer brigar: minha mãe (e meu pai também) foram crianças/jovens extremamente brilhantes (minha mãe foi $1^{\text {a }}$ aluna de neolatinas, ganhou bolsa pra França; meu pai era fodíssimo, passava fome, mas já aos 6 anos ganhava bolsa no primário, tendo aprendido a ler sozinho, na bíblia, acompanhando as leituras diárias dos cultos da família protestante[...] Foram, mas hoje são classe média arrochada, trabalhando demais. Criaram pelo menos dois em três filhos para gênio, pensaram(pensam?) "você vai continuar e conseguir o que eu tive vontade, mas não capacidade..." Os três filhos precisam de muita análise, só dois estão fazendo (não exatamente os dois de cima). 
... imagino poemas à beira do cais... sempre o cais, não há despedidas no aeroporto (CÉSAR,1999,p.19).

Ana C. anuncia, desde o início, a vontade de que suas cartas fossem publicadas. Fazia diversas versões e as reescrevia várias vezes, exercitando o estilo íntimo e confessional, dando tratamento estético à fala que pedia contato. Para ela "escrever cartas é mais misterioso do que se pensa" (CÉSAR, 1999a, p.202).

Em Cenas de abril (1979) lemos diversos trechos de um eu lírico que se remói: "Falo o tempo todo em mim"; "aguardo crises agudas de remorsos"; "Querido diário: vergonha ricocheteia" (CÉSAR, 1979/1992). É neste livro que encontramos a série de poemas "Último adeus, I, II e III". No mesmo ano, publica Correspondência Completa (1979/1992) um livreto no qual escreve uma longa carta para alguém que não conhecemos e assina como Júlia, uma das poucas personagens que cria, contudo, cita Gil, seu namorado da época:

Não estou conseguindo explicar minha ternura, minha ternura, entende? ${ }^{62}$

Fica difícil fazer literatura tendo Gil como leitor. Ele lê para desvendar mistérios e faz perguntas capciosas, pensando que cada verso oculta sintomas, segredos biográficos. Não perdoa o hermetismo. Não se confessa os próprios sentimentos. Já Mary me lê toda como literatura pura, e não entende as referências diretas. (CÉSAR, 1980, p.90)

Apesar de não ser possível a confissão dos sentimentos, eles estão lá, escamoteados pela técnica. Numa carta de dezembro de 1979, sonha com sua maior interlocutora e figura materna, Heloísa Buarque de Hollanda, professora responsável por lhe dar projeção nacional ao incluí-la na antologia 26 poetas hoje, de 1976 :

Meu pai embarcou hoje. Fiquei sozinha e católica. [...] Queria mudar tudo na minha cara. Sonhei que você era minha mãe. Há crises de identidade etc. Não ligo mais para os Grandes Monumentos da História, nada me emociona, esqueci o frisson europeu, bola![...] Estou bem. SOS. Beijos. Ana. (CÉSAR,1999b, p.84, grifos nossos)

\footnotetext{
${ }^{62}$ Cunha Lima (1993) investiga de quais poemas e autores são tomados, versos, títulos e estrutura. Aqui a referência vem de Manuel Bandeira, do poema "O impossível carinho": Escuta, eu não quero contar o meu desejo/ Quero apenas contar-te minha ternura/ Ah se em troca de tanta felicidade que me dás/ Eu pudesse repor/ - Eu soubesse repor - / No coração despedaçado/ As mais puras alegrias de tua infância.
} 
Já em fevereiro de 1980, conta que adotou de vez seu "nome de guerra": Ana C. Lá também comenta o que escreveu num ensaio sobre Caetano Veloso: "a poesia quer é virar prosa; o ensaio quer virar poesia". Neste momento, ela está lendo "Inveja e Gratidão" (1946), de Klein, e diz: "é aterrador. Tomo cada linha ao pé do ouvido e fico paralítica de medo" (CÉSAR, 1999b, p.40). Em março, comenta sua correspondência com Clara Alvim, indicando momentos de inércia e depois intensa produção:

Respondi a Clara: fui razoavelmente sincera e contei que estava fazendo NADA (o nada assumia uma dimensão quase filosófica, ah, ah), e que na certa ia continuar a fazer nada, que eu era constitucionalmente uma escritora, mas nunca seria de verdade, sei lá o que mais, ah sim, que a modernidade me perseguia e eu gostava do cantinho inglês, aventuras apenas ao alcance da mão, e uma preguiça divina, enfim.......]

[...] depois de um lapso no ócio eu tinha virado uma suave máquina de produção, decidida a trazer um caldo precioso todo escrito em inglês...(CÉSAR,1999b, p.46)

No ano seguinte, vieram as publicações de Porthsmouth-Colchester (1980) e Luvas de Pelica (1980) - todas elas editadas e diagramas pela própria autora. Ela fala como escrever pode provoca remorsos:

Passei a tarde toda na gráfica. O coronel implicou outra vez com as ideias mirabolantes da programação. Mas isso é que é bom. Escrever é a parte que chateia, fico com dor nas costas e remorso de vampiro. Vou fazer um curso secreto de artes gráficas. Inventar o livro antes do texto. Inventar o texto para caber no livro. O livro é anterior. O prazer é anterior, boboca"(CÉSAR,1979,p.89).

O primeiro tratou-se de um pequeno livro, no formato de caderno de desenho, em que a poesia parece ter sido, de certo modo, apresentada naquelas formas que sugerem um jogo de decifração. Ela tenta achar "a medida exata entre o acaso e a estrutura", e anota: "Quero que você fique olhando, reconhecendo cada tracinho" (CÉSAR,1979). Para as figuras que aparecem, ela apresenta uma legenda que nos leva a tentar identificar as possíveis derivações de sentido para as silhuetas. O caderno escrito em inglês e português possui uma textura diferente e a impressão reproduz sua letra cursiva, o que nos aumenta a sensação de intimidade. Ali, é possível considerar tanto os desenhos quanto o trabalho estético como uma forma lúdica, quase infantil, de escrita. Lemos: "Less afraid but still cautious" (Com menos medo, mas ainda cautelosa). Neste 
caderno, Ana C. ensaia o que podemos chamar de uma tradução literária de suas próprias palavras, a qual por vezes, leva a uma completa alteração do sentido. Por exemplo, "surrupiando" - que significa tomar posse de algo que não é seu - é traduzido por "disappearing into nothingness" - que, em uma tradução livre, significa “desaparecendo no nada". Um desenho que vira palavra que gera ainda outra. Será que traduzir-se poderia ter algum efeito terapêutico? A possibilidade de usar de outro vernáculo e outra gramática ampliaria a chance de nomeação dos afetos que buscam expressão? Este mis en abyme, promoveria mudanças de perspectiva que gerariam novas experiências de elaboração para o eu?

Em certo momento, Ana C. pensou em rasgar todos os livros e fazer com eles uma colagem. Mais tarde, ela revela:

[...] Se acalmou um pouco o ataque de artes plásticas. Conheci uma menina que está expondo uma coisa genial no Institute of Contemporary Arts, quadrinhos que sobem pela parede da escada com pedaços incompletos dela mesmo.[...] fiquei lendo Caderno B, especialmente sinopse de novela, se você tira o que vem antes ou depois fica mensagem secreta para iniciados, lendo essas sinopses descobri minha teoria da literatura. (CÉSAR,1999b, p.80)

O segundo livro, Luvas de Pelica (1980), é um breve diário de viagem, bastante peculiar, que, com apenas 33 páginas, ao invés de descrever o desenvolvimento de uma esperada sucessão de movimentos e descobertas, expressa imobilidade, o não ir, ou melhor, nas palavras de HOLLANDA (apud. CÉSAR, 2013, p. 443), “o exercício de escrever inúmeras cartas para o ponto de partida, a empenhadíssima construção de um espaço silencioso, em vez da conquista e da exploração do mundo" (HOLLANDA apud CÉSAR, 2013, p.443). Em outra conversa com sua amiga, lemos:

Eu fiz uma versão da minha história bem sem conteúdos para você. Mas eu tenho tara por conteúdos, só a técnica é capaz de me salvar. Deleuze explica. EXISTEM SIM, mas não interessam, acho que só servem para eu ruminar de vez em quando um drama qualquer. Não sei se saio do drama à custa de conteúdos ou à custa de montar na moto. Acho que o $1^{\circ}$.., mas estou louca pelo $2^{\circ}$. Me dá nervoso!

[...] Estou com umas ganas horríveis de escrever, leve, são os conteúdos que me atrapalham.

Mais P.S Conteúdos pode ser que não existam, mas existem as 2as intenções...

Mais P.S Percebo que o lance de anotações tipo agendinha tem a ver com uma certa briga entre o fora e dentro, registro e psicologia, cenografia e interioridade. Registrar com um muxoxo de quem não 
pudesse derramar. Mas para não ficar neo-realista só vale se a tensão

passar. Tem mais aí? Ai, um batonzinho. [...] Prometo que a próxima carta será sem estilo. Às vezes acho que sou louca mansa, mas não, é apenas um brinquedo. (CÉSAR, 1999b, p.6263)

A passagem acima nos demonstra o ímpeto de criar uma escrita leve, sem o peso de seus conteúdos, que não fosse sempre uma imersão em seu universo interior. Um tempo depois, escreverá novamente sobre esse empuxo a uma escrita de si:

O tempo fecha.

Sou fiel aos acontecimentos biográficos.

Mais do que fiel, oh, tão presa! Esses mosquitos que não largam! Minhas saudades ensurdecidas por cigarras! O que faço aqui no campo declamando aos metros versos longos e sentidos? Ah que estou sentida e portuguesa, e agora não sou mais, veja, não sou mais severa e ríspida: Agora sou profissional. (1982/1992, p. 9)

Em um de seus artigos, publicado em setembro de 1982, Ana C. comenta sobre Ângela Melim, uma escritora cuja particularidade é escrever cada vez mais prosa, Ana C. diz que chega a se assustar com a diferença entre o então atual trabalho da poeta e seus livros anteriores. De acordo com ela, os primeiros são de prosas breves que se misturam com poemas,

todas muito orais, muito próximas de uma certa voz que a gente ouve, para as engravatadas primeiras linhas do livro mais recente. .[...]. As primeiras frases do livro engravatado diz: "LM se viu dentro do carro, no meio do trânsito na Lagoa, indo em direção do túnel Rebouças" enquanto a outra diz: "Sobre o suicídio: preciso tomar uma decisão entre pedra ou vidro, estilhaça ou espatifa, porque todas as palavras não cabem num livro". (CÉSAR,1999, p.241,)

O comentário no artigo posiciona sua escrita íntima em contraposição a uma prosa engravatada, que não faz qualquer esforço de transgressão da língua. Nas palavras dirigidas à outra, escutamos as preocupações artísticas de Ana C. É impossível deixar de notar a temática suicidária que habita sua poética. Sobre seu ofício, ela escreve: 
entre um poema e outro, aprendi a ouvir uma prosa de voz íntima, que fala como quem conversa intimamente com o interlocutor, que se apega às exclamações e aos murmúrios da intimidade, e que pede emprestado da conversa a despreocupação com a continuidade lógica e com a sintaxe rigorosa, desobedecendo as regras de desenvolvimento expositivo, à mercê de toda sorte de interferências meio fora de controle, de associações meio súbitas, de interrupções e parênteses que quebram às vezes irremediavelmente, as primeiras sequências. Uma sintaxe infantil, às vezes levemente estropiada e cortada por diminutivos. Uma dicção com um jeitinho[...]Passeios pelo arbitrário[...] E uma história toda estilhaçada em que se localiza uma maior dificuldade: 'As coisas são assim, repetidas, superpostas, entremeadas de, maior dificuldade de ir separando elas com travessões, parênteses, aspas, maior ainda de ir inventando a existência delas com nomes.” (CÉSAR, 1999.p.242)

Seus primeiros escritos se apresentam menos fragmentados, com tom rimado de prosa, mas já existe a busca de uma desconstrução na escrita, uma potência que só se acentua ao longo de sua obra. Segundo Kofman (1996, p.135), "seria a sua arte que daria forma ao psiquismo do artista, e não seu psiquismo que viria à luz através de sua arte." Em uma vertente mais salutar da que viemos trabalhando, ela nos diz que:

Pelo jogo dos processos psíquicos inconscientes, o jogo dos afetos em sua transformação, o das representações na combinatória, o artista tenta repetir o que a criança faz através de suas brincadeiras, antes que a razão e o julgamento lhe venham impor coações. O homem "reverenciado" que é o artista no fundo não é mais do que uma criança que dá aos outros homens a alegria de poder reencontrar, eles também, o paraíso da infância. (KOFMAN, 1996, p.134)

A teus pés (1982/1992) foi o último livro escrito por Ana C. Nele, ao contrário dos anteriores, observamos como sua escrita foi ficando mais condensada. Existe uma economia particular das palavras: ao mesmo tempo em que algumas delas parecem ter um peso maior, outras nos soam simples e despretensiosas, apenas registros. É como se já não se pudesse dizer muita coisa, como se tivesse a sensação de que já falou demais, já foi suficiente a quantidade de chaves oferecidas para desvendarmos seu mistério. A prosa vira cada vez mais poesia, a voz vai se calando e, aos poucos, a fragmentação e o desligamento se infiltram no texto: 


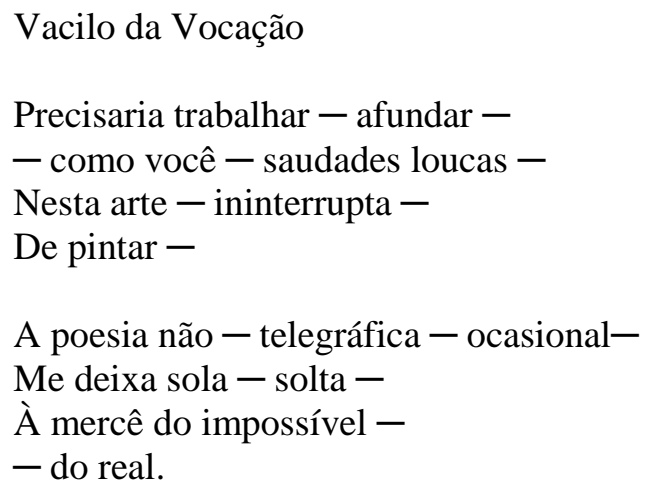

(CÉSAR, 1982/1992, p.29)

A escrita telegráfica nos lembra que as palavras custam caro. Escrito por volta de um mês antes de sua morte, o poema parece trazer uma esperança de que as coisas poderiam ter sido diferentes. Lemos:

Parece que há uma saída exatamente aqui onde eu pensava que todos os caminhos terminavam. Uma saída de vida. Em pequenos passos, apesar da batucada. Parece querer deixar rastros. Oh yeah parece deixar. Agora que você chegou não preciso mais me roubar. E como farei com os versos que escrevi?

Datado de 23-7-83

(CÉSAR, 1998, p.181)

A saída de vida seria incompatível com os versos escritos? Seria possível não escrever? Um pouco mais tarde um de seus versos nos diz: "Não adianta. [...] Alegria! Algoz inesperado" (CÉSAR, 1998, p.192).

Ana C. continuava a escrever mesmo em um estado de profunda depressão. Em 2 de outubro de 83, período em que entra no mar com a intenção de não mais voltar, é publicado, no "Folhetim" da Folha de São Paulo, "Contagem Regressiva", o qual antecipa: “os poemas são para nós uma ferida" (CÉSAR,1998,p.164). Estes são seus versos finais:

$[\ldots]$

Não há ninguém que me interesse e meus versos São apenas para exatamente esta pessoa que deixou de vir ou chegou tarde, sorrateira, de forma que não 


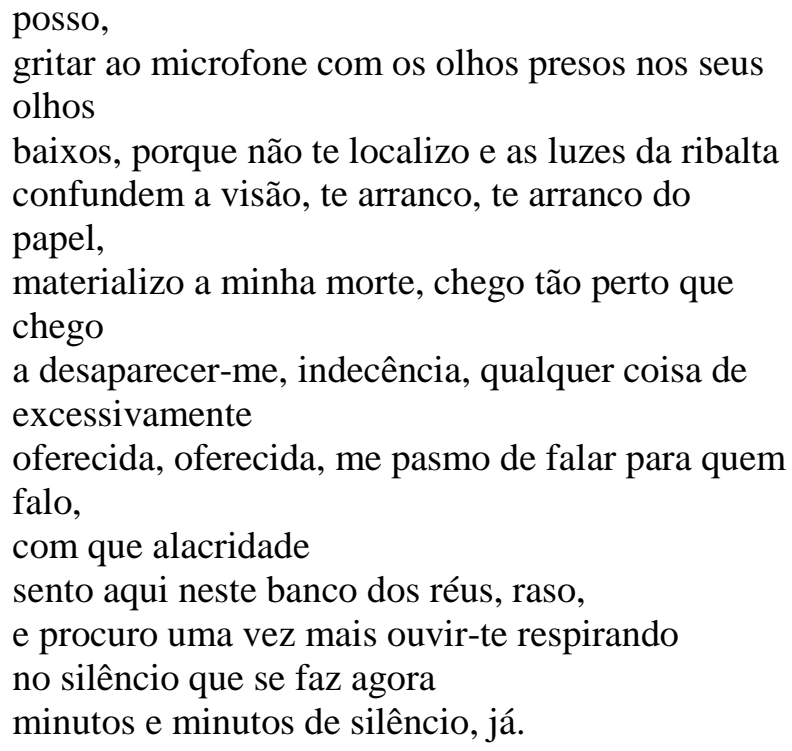

A leitura deste poema produz ressonâncias em nosso núcleo de desamparo. O desejo de desaparecer entrevisto nestes versos alude ao mundo interno de um sujeito melancólico, aquele que não teve sua imagem devolvida pelo outro que dele se ocupou. É necessário que este outro seja arrancando do papel, o que materializa a própria morte. Nestas circunstâncias, o que se pode fazer é buscar a respiração, mesmo que seja em um silêncio que se prolonga e estanca o tempo.

Investigaremos um pouco mais as diferentes modalidades de escrita e quais seriam seus efeitos na dinâmica psíquica de Ana Cristina César. 


\subsection{Preciso voltar aos cadernos terapêuticos}

Carvalho (2003), ao investigar a vida e obra de Silvia Plath, percebeu dois tipos de escrita, uma do recalque, que organiza, contém e separa os conteúdos representacionais e outra, pulsional, que trabalha muito perto da fonte pulsional, revelando o limite representacional da escrita. Derrida (1995) também faz uma distinção entre o escrito e a escritura, sendo esta última aquela que promove uma torção na linguagem, que localizamos mais próxima a esta escrita pulsional de que nos fala a teórica. A dimensão da escrita como phármacon, desenvolvida por Carvalho (2003) nos auxiliará a pensar em uma divisão que também encontramos em Ana Cristina César, por um lado, uma criação do "fogo do final", por outro a dos "cadernos terapêuticos". De acordo com Carvalho (2003, p.103):

Derrida nos lembra que, na visão platônica, a doença natural é comparada a um organismo vivo que é preciso deixar desenvolver-se segundo suas normas e formas próprias, seus ritmos e articulações específicas. Dentre os movimentos do corpo, o melhor movimento é o natural, aquele que, espontaneamente, nasce de dentro, por sua própria ação. O caráter nocivo do phármacon provém, portanto, do fato de que, vindo de fora e contrariando a vida natural, ele é o elemento estranho que desvia o curso normal da vida. Essas noções são introduzidas no momento em que Platão propõe a escrita como phármacon. Contrário à vida, o escrever, phármacon, apenas desloca e até mesmo irrita o mal. Sendo exterior à memória, que é interior, ele a afeta e a hipnotiza no seu "dentro". Platão mantém assim, tanto a exterioridade da escritura, como seu poder maléfico de penetração, capaz de afetar ou de infectar o mais profundo. A escrita como phármacon é um suplemento perigoso que "entra por arrombamento exatamente naquilo que gostaria de não precisar dele e que, ao mesmo tempo, se deixa romper, violentar, preencher e substituir". Derrida ressalta, finalmente, que a escrita - não tendo essência ou valor próprio, podendo sempre mudar de sentido, ora sendo remédio, ora sendo veneno - joga no simulacro e pode servir tanto à vida quanto à morte, residindo, aí, a fragilidade da sua proteção

De acordo com esta noção, o perigo da escrita está justamente no fato dela poder mudar, sempre, de um pólo para outro, de remédio a veneno. Ao longo da obra de Ana C., percebemos uma fragmentação que corresponde ao espírito de sua época, contudo, o fato do objeto de fragmentação ser o próprio eu, não é sem consequências para esse que se desdobra em outras vozes e, depois, parece não saber mais qual é a sua. Dentre os 
escritos de Ana Cristina César havia os poemas, a tradução, as cartas, os ensaios e os "cadernos terapêuticos", ou jornais íntimos, como chamava. Os cadernos terapêuticos, ao que nos parece, teriam a função de curar aquilo que a própria escrita produziu. $\mathrm{O}$ fato de Ana C. querer transformar o anti-literário em literário, o diário, a carta, bem como o desenho em literatura, nos leva a pensar que esta aproximação de sua obra com sua intimidade fez com que o próprio caderno terapêutico tenha perdido sua função de ser, ou melhor, a autora parece não mais ser capaz de encontrar um lugar para soltar seus "ais à vontade", um terreno todo seu. O caráter ficcional da autobiografia parece ter simultaneamente ganhando espaço e invadido, contaminado aquele que não deveria ser apenas simulacro. Observamos em Antigos e soltos (2008) como os cortes de palavras incidiam em especial naquelas que carregavam uma grande carga de afeto, o que parecia conferir ao poema, maior grau de pessoalidade. Esse efeito é o mesmo de um segredo, de algum mistério a ser desvendado. Contudo, ela escreve: "te apresento a mulher mais discreta do mundo, essa que não tem nenhum segredo". Lemos em Ana C. uma escrita que vai se tornando telegráfica. Sua escrita demonstra um desligamento e uma fragmentação que transformam o ganho estético em prejuízo do artista. Acreditamos que seu estilo a tenha levado para um ponto em que o sucesso de sua obra significaria também sua falência (Cf: CARVALHO,2003).

O texto de Ana C., para Souza (2010, p.73), esbarraria em dois gêneros propostos por Bakhtin: o "auto-informe" e a "confissão". O primeiro estaria condicionado àquilo que o autor pode dizer a si mesmo, sem contar com o ponto de vista do outro - o que contaminaria a enunciação. Não poderia haver uma preocupação estética em um auto-informe, uma vez que os elementos estéticos têm seu fundamento no valor dado pelo outro, ou seja, todo acabamento estético estaria fundamentado no olhar do outro. Se o sujeito da enunciação realiza esse acabamento, ele conclui sua própria existência, tarefa impossível, já que essa conclusão seria dada por um ato de criação artística, a qual abriria a vida à existência, e não o contrário.

$\mathrm{O}$ auto-informe daria lugar à confissão a partir do momento em que o caráter puramente individual e solitário do ato criativo se rompe. $\mathrm{O}$ enunciado se transformaria em uma forma de súplica que parte do sujeito para fora dele. Esta, por sua vez, é caracterizada per se a uma permanência inacabada, isto é, há uma abertura que faz com que o pedido vá se fragmentando em direção a um futuro não predeterminado do acontecimento. No entanto, não seria possível um auto-informe puro, já que ele 
implicaria na solidão absoluta e no silêncio. Desse modo, Bakthin irá referir-se às duas categorias como uma só: auto-informe-confissão.

O diário íntimo deveria, portanto, funcionar como esse espaço pessoal do autoinforme, fora do alcance do olhar e da exigência do outro. Porém, se essa separação com o outro acarreta em uma despersonalização, ao invés de um despojamento ou uma desidentificação, pode ser que essa função se torne difícil. O tratamento estético viria para garantir o contorno do eu fragilizado. Assim, buscaria-se evitar a dinâmica do tudo ou nada, a solidão ou a súplica absolutas. Certa vez, quando perguntaram a Ana $\mathrm{C}$. como havia sido a experiência de começar a escrever, e se esta teria sido um diário, ela responde:

Não, eu escrevia poesia, sempre escrevi poesia, mas poesia incomoda
muito. Poesia é muito grilante. Tem um lado grilante da poesia. Ela
não comunica. Isso que você está queixando, que não comunica, acho
que é um fato... [...] Então eu acho que a tentativa de ir para o
diário.......] Havia duas coisas separadas. Havia o diário, onde eu
podia escrever minhas verdades, minhas inquietações, minhas aflições
pessoais, minhas confissões pessoais, meus amores, e havia poesia,
que era uma outra coisa, e que eu não entendia direito o que era. Até
que começaram a se aproximar os dois, entendeu?[...] Percebi que no
ato de escrever a intimidade ia se perder mesmo. A poesia tendia,
queria revelar e o diário não conseguia revelar. Aí as duas coisas
foram se cruzando. (CÉSAR, 1999 a, p.270)

De acordo com Blanchot (1984), o diário íntimo que imaginamos ser desprovido de regras, onde se pode escrever tudo e registrar o dia a dia, está preso a uma cláusula: deve-se respeitar o calendário. Vemos aqui, novamente, o recurso buscado através do controle do tempo:

Escrever um diário íntimo é colocarmo-nos momentaneamente sob a proteção dos dias comuns, colocar a escrita sob essa proteção, e é também protegermo-nos da escrita submetendo-a a essa regularidade feliz que nos comprometemos a não ameaçar. [...] Escrever em cada dia, sob a garantia desse dia e para lembrar a si próprio, é uma maneira cômoda de escapar quer ao silêncio, quer ao que há de extremo na palavra. (BLANCHOT, 1984, pp.193-195)

O diário escrito por Ana C. marcaria a separação com o corpo da mãe, pois estaria desprendido daquela que escrevia para ela. Observamos um movimento de mão dupla: há tanto uma necessidade constante de registro íntimo, quanto a necessidade de trazer esses conteúdos para seu fazer literário. Desse modo, ela evitaria o rompimento total 
com o objeto de amor e, ao mesmo tempo, chamaria a atenção do leitor (e da sua primeira leitora), para seus conteúdos internos. Em Ana C., há uma repetição, a fala simples teve que ser transformada em poesia pela sábia criança que tinha uma mãe professora de literatura; a escrita simples teria um empuxo para ser obra. O estilo que torna inseparável vida e obra talvez faça uma analogia com a comunicação que é facilitada por esta transformação - uma relação fusional é criada em decorrência disso. O espaço poético é um lugar paradoxal, de encontro e afastamento da língua do outro. Em um depoimento de Ana C., lemos:

\begin{abstract}
Não acho que a poesia esconda, acho que a poesia revela, pelo contrário. Ela não esconde uma verdade por trás ou uma via íntima por trás. Mas é também a dificuldade de quem produz, quer dizer, sempre, quando você escreve, tem sempre uma história que não pode ser contada, entende, que é basicamente história, história da nossa intimidade, a nossa história pessoal. Essa história não pode ser contada. Se você conseguir contar sua história pessoal e virar literatura, não é mais a tua história pessoal, já mudou.[...] Mesmo que eu pegue um diário, como tentei fazer, mesmo assim, continua a haver uma história que não pode ser contada. É um tormento e, de repente, é engraçado também, Você não pode contar...[...] Esse mistério você pode chorar em cima dele, soluçar em cima dele, de repente, você pode achar interessante.(CÉSAR,1999 a, pp.262-263)
\end{abstract}

Vemos aqui como a função do auto-informe-confissão não está destituída da sua potência de promover aberturas, não ficando encerrada em si mesma. Ana C., continua em seu depoimento:

Eu queria me comunicar. Eu queria jogar minha intimidade, mas ela foge eternamente. Ela tem um ponto de fuga.[...]Eu acho que existe uma palavra não falada, mas no sentido mais da... da alegria.[...]Na literatura, sempre haverá uma coisa que escapa. Então, não dá nem mais pra chorar em cima disso. A gente pode, inclusive, se alegrar com isso. (CÉSAR, 1999 a, pp.260-261)

Crítica e tradução (1999a) foi um livro que reuniu diversos trabalhos, entre eles, sua dissertação de mestrado na PUC-RJ, que se tratou de uma pesquisa de filmes documentários sobre autores ou obras literárias produzidas no Brasil, intitulada: "Literatura não é documento". Nesta edição, foram reunidos os "Escritos no rio", sessão que traz artigos publicados em vários jornais e outros órgãos da imprensa ao longo entre os anos de 1970 e 80. Além desses, estão incluído os "Escritos na Inglaterra", que trazem a tradução do Conto "Bliss", de Katherine Mansfield, com suas anotações sobre 
suas escolhas lexicais. Finalmente, o compêndio também traz traduções de poemas como os de Sylvia Plath, Emily Dickinson, Anthony Barnet e Marianne Moore. "A tarefa do tradutor" de Walter Benjamin (1923) foi escrito no mesmo ano de "O ego e o Id", de Freud. O tradutor, segundo o filósofo, precisa se haver com o vazio que se abre na tentativa de representar, em outra língua, o significado da palavra original. Podemos pensar que tanto a fonte de origem quanto o termo traduzido são interpretações. A palavra da língua de saída aparece para representar o que não está mais ali, e também para representar o que tem lugar somente no mundo interno de alguém. A tarefa do tradutor, portanto, "corporifica" a hiância que existe entre eu e outro. O exercício de encontrar a melhor palavra - aquela impossível de atravessar o abismo que existe entre duas línguas - transparece nos próprios textos de Ana C., os quais também podem ser lidos como traduções de si mesma. A tarefa de tradução é da ordem de uma impossibilidade, em uma acepção extrema, o que o tradutor faz é escrever um novo poema.

Nos primeiros momentos da vida, a linguagem chega através do outro, que oferece os cuidados da maternagem. É o outro e a cultura em que se vive que oferecem as possibilidades de significação dessas experiências. Lembramos aqui do ruído que pode acontecer nesta troca que se dá entre o adulto e a criança. Como vimos, para Ferenczi (1923), há um caráter traumatizante nesta conversa, o adulto, sua sexualidade e seu inconsciente irão sempre exceder a capacidade de representação da criança, que fala a língua da ternura, e não a da paixão.

Na tradução do conto de Katherine Mainsfield, "Bliss", por exemplo, Ana C. justifica a tradução desta palavra - que não tem correspondência exata no português por "êxtase", e não felicidade:

Extase sugere a sensação de uma espécie de suprema alegria paradisíaca, que só pode ser sentida em ocasiões muito especiais: em momentos de satisfação na relação mãe/bebê, em outras relações apaixonadas "primitivas", em fantasias homossexuais, no êxtase religioso, e, muito raramente, na "vida real", nos relacionamentos com os adultos. Poder-se-ia dizer que o êxtase é, basicamente, uma emoção imaginária cheia de força e do poder próprios do imaginário. (CÉSAR,1999a , p.323) 
Para Benjamin, o tradutor é aquele que salta o abismo (UberSetzer) entre o eu e o outro, o abismo da distância e do tempo. De acordo com Seligmann-Silva (2011, p.13), "o território niilista aberto pelo tradutor é também o terreno de onde brota a melancolia" e, precisamente por isso, "habita nelas (nas línguas), antes de mais nada, o tremendo e originário perigo de qualquer tradução: que os portões de uma língua tão alargada e bem dominada acabem por se fechar, encerrando o tradutor no seu silêncio". Aqui, nos lembramos também de Blanchot (2001), para quem o grande trabalho do escritor estaria

em seu modo de impor silêncio ao interminável, seu modo de crivar o infinito, como se houvesse uma fala incessante, um universo infinito de palavras, ritmos, frases encadeadas, uma linguagem ininterrupta à qual cabe ao escritor cortar, impor silencio emudecer. (BLANCHOT apud MALUFE, 2006, p.44)

Um dos livros mais lidos por Ana C. foi Fragmentos de um discurso amoroso, de Barthes (1981, p.10). Entre seus grifos, encontramos:

\begin{abstract}
Quando acontece de me abismar, é que não há mais lugar para mim em parte alguma, nem na morte. A imagem do outro - à qual estava colado e vivia - não existe mais; ora é uma catástrofe (fútil) que parece me afastar para sempre, ora é uma felicidade excessiva que me faz recuperá-la; de qualquer modo, separado ou dissolvido, não sou recolhido em lugar nenhum; diante de mim, nem eu, nem você, nem um morto, nada mais a falar. [...] Não será o abismo um aniquilamento oportuno? Não me seria difícil ler nele não um repouso, mas uma emoção. Disfarço meu luto sob uma fuga; me diluo, desmaio para escapar a esta compacidade, a essa obstrução, que me torna um sujeito responsável: saio: é o êxtase.
\end{abstract}

Sabemos que a sensação de êxtase, um "excesso inquietante" 63 é característica dos estados maníacos. Não entraremos nos detalhes do conto "Bliss", mas achamos interessante o fato de que, após o falecimento de Ana C., sua mãe tenha feito a tradução desse trabalho.

Não é gratuita a multiplicidade de vozes no texto de Ana C. Ao trazer para seu texto a voz de outros autores, há uma dissolução da ideia de autor e temos que incluir a

${ }^{63}$ Ana C. (1999 a, pp. 249-250) em setembro de 82, escreve para o "Jornal Leia Livros" um artigo com o título "Excesso inquietante", no qual lemos: "as mulheres são um pouco doidas e o homens um pouco menos". [...] Será que a solução é o fincar-pé masculino, que afirma, dá forma, tem causa e lugar - no máximo?[...]É isso aí, literatura é de um material como que estrangeiro, que nos separa dessa proximidade do sentimento bruto, nos descola de nós e da língua de nossas pessoas." 
possibilidade de que o texto estaria referindo apenas a ele mesmo e às relações lógicas e poéticas - do mundo literário. O eu lírico não é nunca capturável, escorrega para a página de outros livros, línguas e diários.

Como nos aponta Souza (1999), a lírica fragmentada de Ana C. é uma marca de seu tempo, onde o que aparece nas poesias é a questão da identidade, das ambiguidades de gênero e do desejo. Sua poesia faz uma espécie de denuncia irônica da construção do texto e do próprio sujeito da enunciação, a qual narra sua autobiografia, através de um refinado manejo de técnicas e uma contínua sedução.

Os efeitos de época são vividos pelos pais e a cultura, responsáveis por oferecer um suporte para aquele que nela ingressa. A fusão entre arte e vida, diário e não diário, autobiografia e ficção, confissão e segredo, em Ana C., têm nela um efeito subjetivo, para além de ser um estilo representante de uma época. Treze dias antes de falecer, ela escreve:

Dia 16 de outubro de 1983

Não quero agora computar as perdas. Perder é uma lenha. Lá fora está sol, quem escreve deixa um testemunho. Reesquentando. Joguei fora algumas coisas já escritas porque não era o testemunho que eu queria deixar. É outro. Outro agora. Acredite se puder. [...] Chega desse lero, Poesia virá quando puder. Por enquanto, Filho, é isso aí apenas. Saí ao sol onde tentei um do-in, me sinto exaurida. Lembra que o diário era alimento cotidiano? Que importa a má fama, depois que estamos mortos? Importa tanto que abri a lata de lixo: quero outro testemunho. Diário não tem graça, mas esquenta, pega-se de novo a caneta abandonada, e o interlocutor é fundamental. Escrevo para você sim. Da cama do hospital. A lesma quando passa deixa um rastro prateado $^{64}$

Leiam se forem capazes.

(CÉSAR,1998,p. 201, grifos da autora)

Quando traçamos as pistas que Ana C. nos deixa em seu texto e buscamos as referências que ela faz, não sabemos se aquele outro poema deveria ser considerado em sua totalidade, como um eco de sua voz. Temos a impressão de que esse recurso fosse, para além da intertextualidade, um modo de colocar nas palavras de outros poetas os afetos que sente, mas não pode dizer. Como traduz em um poema: "É ilícito, para não dizer fatal, ser pessoal, e indesejável” (CÉSAR, 2008, p.445). Nos lembramos aqui da

\footnotetext{
${ }^{64}$ Aqui encontramos a citação de um poema de Sylvia Plath intitulado "Sleepers", de 1959. Na segunda estrofe, podemos ler: "Curtained with yellow lace./Through the narrow crack/Odors of wet earth rise./The snail leaves a silver track." In: Plath, Sylvia. Collected Poems. London: Faber and Faber, 1981, p. 122123. Agradecemos à Ana Cecília Carvalho pela referência.
} 
descoberta da teoria literária de Ana C.: se cortar o início e o final, resta o mistério. Ela cria uma personagem, um duplo de si, que é e não é ela. Em rascunhos encontrados post-mortem lemos as preocupações acerca da relação entre o real e o ficcional, sempre presente nas reflexões da poeta:

penso relações em forma de:

-indagação constante: qual a relação entre o texto e o real: o poema fala do real? O real vive ou morre no poema? posso possuir o real pelo texto?

-trajetória não-linear (diálogos entre textos) em direção à aceitação do paradoxo: o ser perde-se no poema mas ao mesmo tempo é no texto que se constrói o ser

-> perder o real (escrevê-lo) é recuperá-lo do silêncio (ganhá-lo)

- diálogo/debate entre a consciência do paradoxo e o desejo de solucioná-lo, evitá-lo, ganhar ou perder, e não ganhar e perder simultaneamente.

- real -> sentimentos do sujeito, as relações sociais, a paisagem. Qual o estatuto do real (ser) no texto? O ser se perde no poema (nele morre) ou nele se constrói (vive)? O poema dissipa ou produz?

(CÉSAR apud. MALUFE, 2006, p.44)

Através desses rascunhos, vemos o trabalho de construção lógica sobre a escrita, sua proximidade ou distância com o real e com o que se vive. O ser se perde no poema ou nele se constrói? Perguntamos também com Lambotte (1997, p.103):

Que lugar ocupa a partir de então, no seio da série de proposições lógicas, o sujeito melancólico? Ou, mais exatamente, atrás de que função preenchida pelo "eu" se dissimula ele? Pode ele ainda apreender-se em um discurso que se sabe destinado a recobri-lo?

E ainda, será que a dimensão de reparação que encontramos no processo sublimatório ficaria comprometida, uma vez que a tentativa de construção do eu-lírico no texto reitera a ficção da construção do próprio eu? Tentamos responder com as palavras da autora:

Assim que o sujeito se sinta "existir" em um movimento, isso não lhe indica o lugar que ele ocupa neste movimento, na medida em que ele só apreende aí o aspecto fugidio, o momento da interrogação. Deixese ele encadear no fluxo do pensamento ou tenha ele mesmo provocado o curso, o "eu" do enunciado parece só pertencer à formulação do relato descritivo, o que se encontra, aliás, confortado no sentimento experimentado pelo melancólico - e de que ele nos faz 
partilhar - de expor uma história que não seria sua. (LAMBOTTE, 1997, p.104):

Ana C. está entre dois mundos, habita uma ponte entre o mundo externo, que parece falar uma língua diferente da sua, e um interno, cujas chaves de decifração foram perdidas por ela mesma, e é como se só fosse possível existir enquanto se está pensando (Cf: DERRIDA,1995). Um de seus poemas mais conhecidos diz:

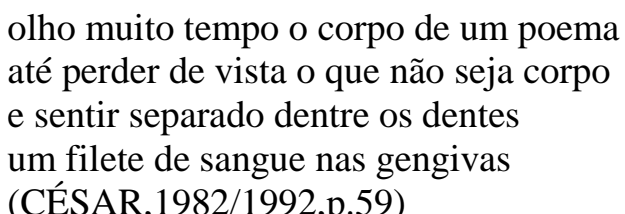

(CÉSAR,1982/1992,p.59)

Identificamos com Lambotte (1997), um modo de pensar próprio do melancólico, bastante paradoxal: ele é submetido tanto à pressão das ideias, quanto à ruptura dessas associações que se precipitam em um circuito lógico sem fim, que termina por voltar-se sobre ele mesmo. Para ela, haveria um "fechamento de circuito", isto é, não se trataria de uma falta de argumento, mas a sucessão de encadeamentos lógicos acabam levando o sujeito a seu ponto de partida, ao momento que deflagrou as associações. $\mathrm{O}$ melancólico, então, estaria situado entre dois espaços vazios: um círculo lógico, que "contribuiria para transformar o mundo sensível em um conjunto de relações; e outro, definido pelo que o sujeito revela de sua interioridade, contribuiria para tornar inapreensível um ego votado ao desvanescimento" (LAMBOTTE,1997,p.99). É a vivência desse "entre-dois-vazios" que faz com que o corpo do melancólico lhe escape e seja percebido como estranho a ele mesmo, além disso, esse entre-dois faz com que seu discurso lhe pareça 'soar falso' e originar-se de algum outro.

Dessa forma, o discurso melancólico compreende um conflito entre a mistura das vozes do supereu e a tentativa de expressão do ego, o que parece reproduzir o castigo de Eco, personagem do mito de Narciso. Eco era uma bela ninfa que foi punida pelos deuses por querer ter sempre a última palavra. Ela, então, teria somente as últimas palavras do outro para expressar-se. Apesar da limitação imposta, Eco ainda consegue se apropriar da fala do outro para se comunicar e ser ouvida. Ela tenta traduzir sua intenção amorosa com Narciso através de um jogo com as perguntas que o belo rapaz faz da beira de um lago. Na versão de Ovídio, é quando Narciso está perdido que Eco 
aparece. Ele pergunta: “Tem alguém aqui?” e ela responde: “Aqui!!”.O discurso de Eco precisa da palavra de Narciso. Mas ele, fascinado com a sua imagem refletida na superfície do lago, não pode se arriscar a perdê-la novamente, sendo capturado pela visão de seus próprios contornos, estranhos a ele. Ao depender de um outro para conseguir dizer algo seu, a palavra é realmente de quem? A fala de Eco terá sempre raízes na palavra do outro.

Lambotte (1997, p.101) nos auxilia a pensar um pouco mais sobre o eu do melancólico:

O "eu" do melancólico não é um "eu" atributivo que deveria o fundamentado de sua existência à consciência de sua atividade; é um "eu" irônico que só pode pensar-se em função do próprio movimento do pensamento, um "eu" que se especifica unicamente pelo movimento que se dirige a apreendê-lo, da mesma forma que este movimento se dirige a apreender todas as coisas. Isto é dizer também que ele desafia toda a origem ao querer constituí-la, que ele não se apreende senão em um movimento e que ele repousa unicamente no encadeamento indefinido de proposições lógicas umas em relação às outras.

Identificamos, na poesia de Ana C., essa "compulsão a pensar" ora descrita. Essa característica melancólica traz uma predisposição, uma espécie de vocação para o trabalho com o pensamento e, também, para o trabalho artístico - ambas presentes na vida da poeta. Contudo, essa consciência pode levar a um constante confronto com essa dimensão do não-sentido que acompanha a evidência de que o texto é apenas uma construção, nas palavras de Ana C.:

Infelizmente ou talvez felizmente - é esse o mistério [...] - um texto é só texto, ele não é pele, ele não é mãos se tocando, ele não é hálito, ele não é dedos [...] Acho que existem várias maneiras de você lidar com esse problema de que o texto é texto. Existe, de repente, uma consciência trágica: o texto é só texto, nada mais que texto. Que tragédia!

(CÉSAR,1999a , p.265-266)

É no não lugar, no entre, que o eu melancólico existe, o que, paradoxalmente, o protege da dinâmica do "tudo ou nada": "Sou coisa ou poeta". Pensamos que esse entre lugar está relacionado com o segundo momento da sublimação, entre o desinvestimento e o novo investimento libidinal. Na melancolia, esse segundo momento da sublimação seria mais prolongado, deixando mais tempo para a pulsão de morte se infiltrar e operar, 
desligando as representações dos afetos. Nos lembramos que as tragédias são sempre anunciadas pelo coro, o que não chega a impedir ou alterar o destino do herói.

Nos últimos poemas de Ana C. aparece a ideia da escrita como testemunho, como veremos a seguir. A "Pasta Rosa" cuidadosamente organizada, assemelha-se àquela encontrada após a morte da poeta Emily Dickinson, com uma extensa coleção de poemas não publicados.

\subsection{Quem escreve deixa um testemunho}

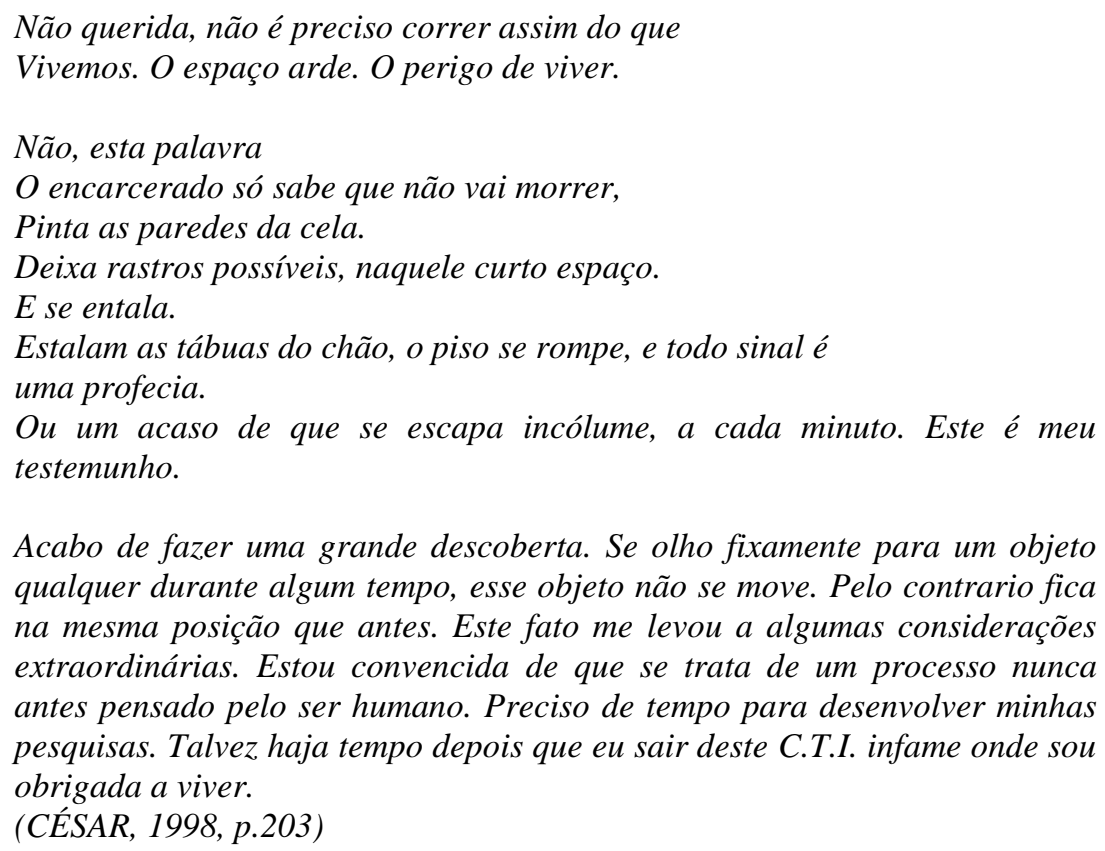

Ditar poemas para a mãe que escreve. Essa cena não é trivial, pelo contrário, esse "evento-tela" parece ter uma importância central na vida e na obra de Ana C. Segundo Lambotte (1997, p. 352), um evento-tela é um evento lógico que responderia melhor à resignação apática do melancólico e daria a seu discurso um semblante de justificação. Ela nos diz que, se "lhes acontece atribuir ao evento a causa de seu estado, é por uma espécie de lógica formal desafetivizada, sem a qual eles permaneceriam suspensos no tempo, faltosos de uma narrativa que se deixaria construir". 
De acordo com a psicanalista francesa, o melancólico está suspenso ao ideal do eu essencialmente materno. Ela nos lembra sobre o paradoxo da afirmação da negação, que faz da compulsão a negar do sujeito - a afirmação do nada como identidade -, não somente a "tradução da falha especular, mas também a recusa ativa de toda assimilação a qualquer modelo suscetível de manchar o referencial ideal que lhe serve de moldura.[...]"(LAMBOTTE,1997, p.333). Isto é, o dizer não seria uma possibilidade de existir pelo jogo e pela força da negação, que opera uma diferenciação e uma oposição ao outro. Pensamos que o jogo poético de Ana C. está ligado a esta dimensão, há sempre um outro ao qual se referencia, o leitor, os poetas que traduz e os eu-líricos das poesias que consome. A poeta faz diversas referências ao poema "Ao leitor" de Baudelaire, escrito em As flores do mal (1861/2011, p.30): "leitor hipócrita, - meu semelhante, - meu irmão.” Esse trecho também aparece em outro poeta que habita suas estantes e suas páginas, T.S. Eliot. Em The wasteland, a referência se repete no poema intitulado: "The buriel of the dead" (O enterro dos mortos): You! Hypocrite lecteur! mon semblable, - mon frére! Temos aqui um exemplo do labirinto e do mis en abyme a que nos referimos: assim, no jogo de decifração, deveríamos ler os sinais de despedida que aparecem e se repetem como uma anunciação ou então, essa própria construção seria responsável por uma "poética do suicídio", como aponta Carvalho (2003). Acreditamos que ambos os fenômenos não se excluam em Ana C..

Como vimos, encontramos sempre uma indicação deste outro que funciona como um apoio identificatório e, com o trabalho poético, há uma transformação, uma alteração desse material que vem daquele e passa a fazer parte do eu-enunciador de seus poemas. O entrelaçamento entre o real e o ficcional, entre o eu e o outro, sugere que a voz da poeta aparece em negativo, que foi mantida secreta, resistindo ao movimento fusional, o qual aparece na cena em que não sabemos quem está de fato escrevendo. A relação com aquela que primeiro teria "traduzido suas palavras" e, depois, com o leitor, garante um mínimo de identificação. Lambotte (1997, p. 342) nos relembra que: "sem identificação, nada de imagem, apenas uma moldura vazia, ou ao menos uma moldura que encerra uma paisagem sem interesse e cujo relevo se deve situar no pano de fundo inacessível. $\mathrm{O}$ investimento e identificação com a atividade de escrita é feita sob o modelo de apoio narcísico, o que pensamos ter tornado difícil para Ana C. operar uma desidentificação, tornando-se dela dependente para a estruturação de sua identidade. No poema abaixo, não conseguimos deixar de pensar no mecanismo melancólico descrito 
por Freud, em que a impossibilidade de desligamento faz com que a sombra do objeto caia sobre o eu:

Mecha branca

A despigmentação da tua palavra

Me incita, me entristece

Acho que atrai alguma sombra minha

Algum elo da nossa fraqueza

Essa despigmentação irregular

Que nos atiça

É antes uma sombra recriada uma forma ainda de esperar

Quando não esperamos mais - e nem ainda -

Escondo a tua sombra nesta mão

(CÉSAR,2008,p.95)

Retomamos a noção do bebê sábio de Ferenczi (1933), que precisa amadurecer rápido demais para cuidar de si e do outro que seria responsável por ele, à custa do sofrimento que acompanhará a impossibilidade de metabolizar o experienciado, bem como da marca do desamparo que lhe é impressa. O encantamento promovido pela habilidade com as palavras teria condicionado a poeta a usar suas palavras para garantir a presença do objeto amado, que aparece, desta maneira, como testemunha das suas experimentações artísticas. Se no início havia uma brincadeira de palavras, mais tarde, o jogo se torna sério. A simples presença do seu corpo não teria sido suficiente para convocar o afeto que precisava. Era preciso um esforço de composição para conseguir abaixar o jornal que o pai lia, ou entrar para a pasta de composições escolares de sua mãe. "Me leva no seu giz" (CÉSAR,2008,p.143), escreve. A criança tenta entrar no universo materno através das letras, do livro. Como exemplo desse jogo de espelhamento, escolhemos o poema abaixo, que começa com um verso tomado de Walt Whitman (1989):

Amor, isto não é um livro, sou eu, sou eu que você segura e sou eu que te seguro (é de noite? estivemos juntos e sozinhos?), caio das páginas nos teus braços, teus dedos me entorpecem, teu hálito, teu pulso, mergulho dos pés à cabeça, delícia, e chega -

Chega de saudade, segredo, impromptu, chega de presente deslizando, chega de passado em vídeo-tape impossivelmente veloz, repeat, 
repeat, repeat. Toma este beijo só para você e não me esquece mais. Trabalhei o dia inteiro e agora me retiro, agora repouso minhas cartas e traduções de muitas origens, me espera uma esfera mais real que a sonhada, mais direta, dardos e raios à minha volta, Adeus! Lembra minhas palavras uma a uma. Eu poderei voltar. Te amo, e parto, eu incorpóreo, triunfante, morto. (CÉSAR, 1982/1992, p.111)

Abandonar a poesia seria fazer o mesmo como objeto de amor (morto-vivo), o qual ela tenta fazer reviver, chamar para a conversa e se mostrar. Esse abandono talvez não tenha sido possível por causa dos remorsos melancólicos que viriam, retaliação ou retorno da libido que continha a violência necessária para romper o vínculo tão fortemente estabelecido. A potência desidealizadora e desterritorializadora da arte pode ter promovido esse movimento, mas pode também ter desencadeado um efeito oposto. Para os sujeitos que elegeram a identificação narcísica como modelo privilegiado de investimento, a separação tem por consequência a despersonalização e o despertar das agonias impensáveis, nas quais o sujeito se defrontaria com a parte nadificada da sua imagem refletida por um espelho cego. Lemos em Ana C.:

Eu penso a face do poema/ a metade na página

Partida

Mas calo a face dura

Flor apagada no sonho

Eu penso

A dor visível do poema/ a luz prévia

Dividida

Mas calo a superfície negra

Pânico iminente do nada

(CÉSAR,1998,p.88)

Através de uma de suas cartas, sabemos que Ana C. (1969, p. 269) Esteve bastante investida no texto de Foucault "O que é um autor?" Ali, o filósofo, ao examinar a "função autor", afirma: "é preciso que ele faça o papel do morto no jogo da escrita". Diante desta afirmação, a noção de obra problematiza-se tanto quanto a individualidade do autor. Nesta esteira de pensamento, Blanchot (2011, p. 95) diz que, "talvez a arte exija que se brinque com a morte, talvez introduza um jogo, um pouco de jogo, onde não existe mais recurso nem controle".

Pensamos na relação particular criada por Ana C. com a figura das mãos que “contornavam sua sintaxe", isto é, um suporte identitário teria vindo através das mãos 
maternas, e não de seu olhar, que estava na folha branca do papel. O corpo do poema seria o espelho onde teria sido possível se reconhecer, fragmentar, inventar, se desfazer e refazer. A leitura que Souza (2008, p.52) faz de sua lírica se aproxima do que temos articulado:

\begin{abstract}
A poesia de Ana C. , assim como a produção de vários colegas de sua geração, é a poesia do corpo: esse é o território por onde a poeta pode conceber seu drama, longe da repressão do desejo. Tal marca indica outro aspecto: a dissolução do sujeito. Paz defende que a crítica do tempo da utopia, realizada pelo corpo e pela imaginação, é também a crítica do sujeito: o poeta não é mais um ator, e sim, um "momento de convergência das diferentes vozes que confluem para o texto...(o sujeito é uma cristalização mais ou menos fortuita da linguagem". A voz do poeta é a voz de ninguém, a voz da outridade.
\end{abstract}

De acordo com Winnicott (2000, p.403), é através da dimensão corporal que poderemos pensar na simbolização primária. A sublimação depende da simbolização secundária que, por sua vez, possibilita os processos secundários. Para Freud, o eu é uma superfície corporal, assim, é preciso a construção de um corpo capaz de suportar as angústias de liquefação, de desaparecimento no nada. Inicialmente, é o corpo materno que deve envolver o pequeno sujeito, oferecendo uma experiência corporal que garanta a continuidade do existir, condição necessária para a diferenciação do eu/não- eu. A importância do corpo na obra da poeta nos leva a pensar numa escrita que buscava, no texto, "mãos se tocando" com luvas de pelica. Esse corpo é erotizado e tornado presente no poema, ele incomoda, seduz e atinge o leitor. Quase se pode sentir seu cheiro: "Lavei os sovacos e os pezinhos. Preparei o chá. Caso ele me cheirasse... Ai que enjôo me dá o açúcar do desejo" (CÉSAR, p.63). Na leitura de Malufe (2006, p.44) os versos de Ana C.

são sensualmente corporificados, uma linguagem que gruda no corpo, que toca corporalmente quem lê. Aqui talvez esteja o principal afecto feminino da linguagem para Ana C.: o "grudar" no corpo, o corporificar. Grudar no corpo é também grudar no corpo da letra o movimento, o ritmo, o tempo, a velocidade. Tornar presente. Tornar perceptível as forças de um movimento que, até então, ninguém sentia. 
A vitalidade desse empreendimento enriquece ainda mais a obra de Ana C. É como se impulsionasse ou forçasse uma presentificação do corpo no tempo: "é agora, nessa contramão" (CÉSAR, 1982, p.15). Mais uma vez o movimento paradoxal da escrita, que ao mesmo tempo que constrói por partes um corpo no poema, também o desfaz, o estilhaça, fragmenta. Para Castelo Branco (1995, p.91), haveria na escrita feminina um saber especial:

Saber da falta, do vazio, é um saber feminino e um saber precioso. Talvez dada sua inexorabilidade - terrível, porque faz saber que além dos objetos, além das construções, além da fantasia há o nada ou não há nada. Conviver com esse nada, saber dos limites, este é um saber feminino [...]. Zombar da onipotência, do sujeito fulgurante, pleno e onipotente, elas sabem, e sabem o peso e o preço de tanto fulgor, tanta plenitude e tanta onipotência.

“Toda a mulher fala com o corpo, se comunica com o corpo", diz Ana C. (CÉSAR, 1999, p.272.) A voz feminina, traz a marca do corpo, mas também do real, do silêncio que se oculta por trás dela. Em depoimento dado em 1990, Heloisa Buarque de Hollanda comenta alguns aspectos da poesia de Ana C.:

[...] Essa coisa do feminino nela era a possibilidade do segredo. Esse segredo em termos de pacto, um pacto que ela fazia com o leitor, um pacto que ela fazia com o autor, um pacto que ela fazia com o tradutor, ela vivia de pactos. Um "pacto" que eu estou falando, no sentido do ser... um segredo. Quando você faz um pacto , o pacto é um segredo seu, é uma coisa irracional, um pacto de morte. Você faz um pacto, é um compromisso cego; não é um acordo, é diferente. Isso é o que ela faz com o leitor. Se você está a fim de fazer acordo, vai ler outra pessoa. Se você não fizer um pacto com ela, não serve. Acordo ela não faz. E aí a tradução fica muito atraente, porque a tradução é outro pacto. Eu vou descobrir o que o outro não me disse. Eu vou ficar por trás daquela palavra, é uma coisa assim.

(HOLLANDA in: VIEGAS, 1998, p.131-132)

Na poesia de Ana C., a dimensão do corpo se expressa na sonoridade das palavras, no ritmo, na entonação. Lemos o texto e somos lidos por ele. Assim, vislumbramos que a obra que se pretende autoral, precisa entrar em contato com a radicalidade dos efeitos que a alteridade produziu para que, finalmente, seja possível a diferenciação do que é Eu e o que é o outro, através do estilo. Para isso, contudo, seria necessária uma desidentificação, é "preciso justamente que sejamos nós mesmos para nos descobrirmos 
identificados ao outro. Desta maneira, sendo inconsciente a identificação, é impossível torná-la consciente de outro modo que não seja desidentificando-se" (MANNONNI, 1994, p.175). Mannonni (1994, p.185) nos diz também que "a literatura, o teatro ou o cinema são como exercícios de identificação para o autor, os atores e o espectador".

A sublimação implica um laço social, isto é, a pulsão que tem esse destino, se não visa o compartilhamento, certamente o promove, uma vez que tenta possibilitar um tipo de comunicação que não será feita somente pela via do entendimento racional, mas principalmente pela via dos afetos e das emoções. A fim de concluir esta sessão, gostaríamos de incluir os poemas da série "Fragmentos 1,2,3,4,5,6," os quais, ao nosso ver, representam todo o argumento aqui desenvolvido. Nela série, observamos a desconstrução do eu, as tentativas de reconhecimento, a mãe, a condensação da palavra, bem como a fragmentação que foi produzida ao longo do processo criativo. Palavra puxa palavra, uma ideia traz outra: deixamos então que esses versos amarrem, por si só, nossos objetivos centrais:

Fragmento I

Efusão de palavras

Aventura de registrar a fenda

Desistir da fluência

De todos os truques

Da bruta castidade.

(Nem me reconheciam em versos naquele tempo)

Qualquer coisa tua me lembra

A mãe difícil percorrer

Naquele tempo

As mesmas formas de pureza recusada:

A dúvida

A pele que refaço

Fragmento 2

Curta efusão de palavras

Aventura tímida de registrar a fenda

Desistir da fluência

De todos os truques

Da bruta castidade que me aflige

( me reconheciam em versos naquele tempo)

Porque talvez qualquer coisa tua me lembre

A mãe que era difícil percorrer

Naquele tempo

preservar

As mesmas formas da pureza recusada-

Nela reside a dúvida

A pele que refaço 
Fragmento 3

efusão de palavras

Aventura de registrar a fenda

Desistir da fluência

De todos os truques

Da bruta castidade

(me reconheciam em versos naquele tempo)

qualquer coisa tua me lembra

A mãe difícil percorrer

Naquele tempo

As outras formas

pureza recusada

a dúvida a pele

que refaço

Fragmentos 4

efusão de palavra

aventura

bruta castidade

(me reconheciam)

lembrar a mãe

percorrer

aquele tempo (em versos)

\section{Fragmentos 5}

efusão

aventura

bruta

(reconhecer)

a mãe

difícil

tempo

\section{Fragmentos 6}

aventura

bruta

(em versos) 


\section{Considerações finais}

Nos perguntamos ao longo deste trabalho sobre o que faz com que um sujeito tenha sua linha de desenvolvimento psíquico preservada enquanto outros, não. Compreendemos que aquele que nos precede, e é responsável pela maternagem, é também o outro que irá produzir traumatismos, veicular intensidades que irão exceder a capacidade do pequeno sujeito de metabolizar o que é trazido junto dos cuidados. Assim, nos atentamos aos elementos que impedem o aproveitamento dos recursos e os benefícios que poderiam ter sido obtidos através de novas experiências positivas com o mundo: a ligação da pulsão de morte através da pulsão de vida.

O tema da desfusão pulsional ocupou um lugar fundamental em nossa discussão, uma vez que, como observado, esta é constitutiva do processo sublimatório, colocando o ego em perigo de maus tratos e morte. Através da desfusão e refusão pulsional, foi possível explicar o fenômeno do masoquismo moral, elemento que, para Freud (1917[1915]), distingue a melancolia do trabalho de luto. Desse modo, é a relação especial entre o ego e o superego que caracterizam o complexo melancólico.

Nos estudos sobre a melancolia, trabalhamos especialmente na tensão entre dois modos, aparentemente distintos, de se compreender o fenômeno: de um lado, entende-se que a perda do objeto de amor é elemento constitutivo do sujeito, a falta em torno da qual se erigiria o eu. De outro, a perda do objeto de amor primordial, apesar de fazer parte do desenvolvimento psíquico de todos, passa a ter uma consequência diferente para alguns sujeitos. Vimos que a qualidade da relação de objeto, anterior à separação eu/outro, é um elemento determinante no modo de enfrentamento dessa dolorida divisão. A melancolia está, portanto, relacionada ao traumatismo de uma abrupta separação que ocorre quando o pequeno sujeito já esboça o mundo exterior, e este é investido como algo separado de si.

A fim de levarmos a cabo nossos objetivos traçados, teremos que considerar também a existência de diferentes tipos de sublimação. Haveria aquelas que não trariam risco para o sujeito, como vimos com Mijolla-Mellor (2010). Para ela, a sublimação se trata de uma escolha, consciente ou inconsciente, assim como a escolha da neurose. Kupermann (2003), a partir do paradigma do humor, nos mostra como a 
sublimação possui uma capacidade de promover uma desidealização e uma desterritorialização do eu, o que, além de possuir uma dimensão política, por ser rebelde à norma e "não resignado", traria a possibilidade do sujeito encontrar formas mais criativas de satisfação, as quais garantem a individualidade e um ganho narcísico. Já Silva Jr. (2011) e Carvalho(2003) nos apontam para os limites e os perigos da desfusão pulsional que acompanham a sublimação. Estas estariam muito próximas da fonte de irrupção pulsional, que transbordaria além do limite (limens) de sua contenção. As primeiras seriam tributárias da pulsão de vida, enquanto as últimas, da pulsão de morte. Ressaltamos que a pulsão de morte não é sempre sinônimo de destruição. Sua atuação, entendida como desligamento e desobjetalização, como postula Green (), é o que permite ao eu não se enrijecer em um narcisismo mortífero. $\mathrm{O}$ desligamento promovido por ela é importante para o desinvestimento do mundo externo, permitindo o sono, o recolhimento da libido e a redistribuição da energia libidinal.

Imbuídos da noção de que a sublimação é mediada pelo eu, de que a obra de arte é um objeto narcísico, e de que é exatamente a instância egóica que está comprometida no conflito com o superego na melancolia, teremos que levar em consideração os efeitos da sombra do objeto na arte. $\mathrm{O}$ artista pode se confrontar com elementos que estavam silenciados, protegidos por poderosos mecanismos de defesa e contaminados pela pulsão de morte, como, por exemplo, a identificação ao nada e ao movimento evanescente de desaparição do objeto, o que causa, retroativamente, um efeito iatrogênico.

A análise do material estudado nos levou a entender que a situação de exílio promovida, tanto pela melancolia, quanto pela experiência da escrita, poderá ser justamente o que permitirá ao escritor melancólico, se aventurar em novos amores, e não somente naquele que lhe serviu de referência, impossível de ser abandonado. Através do "silêncio, do exílio e da astúcia", o sujeito passaria a existir em um "entre lugar", nas pontes que saltam o abismo aberto pela experiência da linguagem, reproduzindo a dinâmica melancólica. Contudo, ao encará-lo, ele se paralisa: tragicamente encontra o nada como seu novo objeto de amor. O artista nos sugere que essas fissuras sobre as quais se constrói a ficção, de si e do mundo, carregam a esperança de que o cais seria apenas um ponto de partida, e não a sentença de chegada. 
Gostaríamos de estender a compreensão do processo sublimatório para além do paradigma neurótico. O destino da pulsão que é a sublimação traz consigo resíduos-ecos dos objetos que amamos. No caso de Ana Cristina César, percebemos que a busca por uma palavra única cobrou o preço de não se poder mais apenas dizer. Em seu fazer literário, há um reencontro com aquilo que já se sabia ferido, uma poesia cuja urgência não prevê espera; no final, o poema "fagulha" se transforma em fogo, contudo, consumindo aquilo de que se alimenta.

Entendemos então, que as sublimações que fazem uso do trabalho de melancolia - e não do trabalho de luto - estão mais sujeitas aos efeitos da pulsão de morte, decorrentes da desfusão pulsional. O objeto que será reinvestido continuará a ser um objeto narcísico, que teria a função de espelho, de duplo do sujeito. Esse espelhamento pode funcionar como continente, mas pode, também, esgarçar ainda mais a trama do eu, trazendo à tona os objetos cindidos, em um luto que não se completa, mas reabre a ferida narcísica. A construção de uma outra versão de si nos poemas poderia ser reparadora, todavia, vimos como ela também pode promover um maior estranhamento de si. $\mathrm{O}$ autor pode não se reconhecer naquilo que fez, ou pode dizer e saber mais do que queria. O que foi perdido permanece inconsciente, mesmo com todas as respostas encontradas.

Assim, a tentativa de "registrar a fenda" com as palavras acaba produzindo, por fim, uma aventura bruta, em versos. 


\section{ANEXOS}
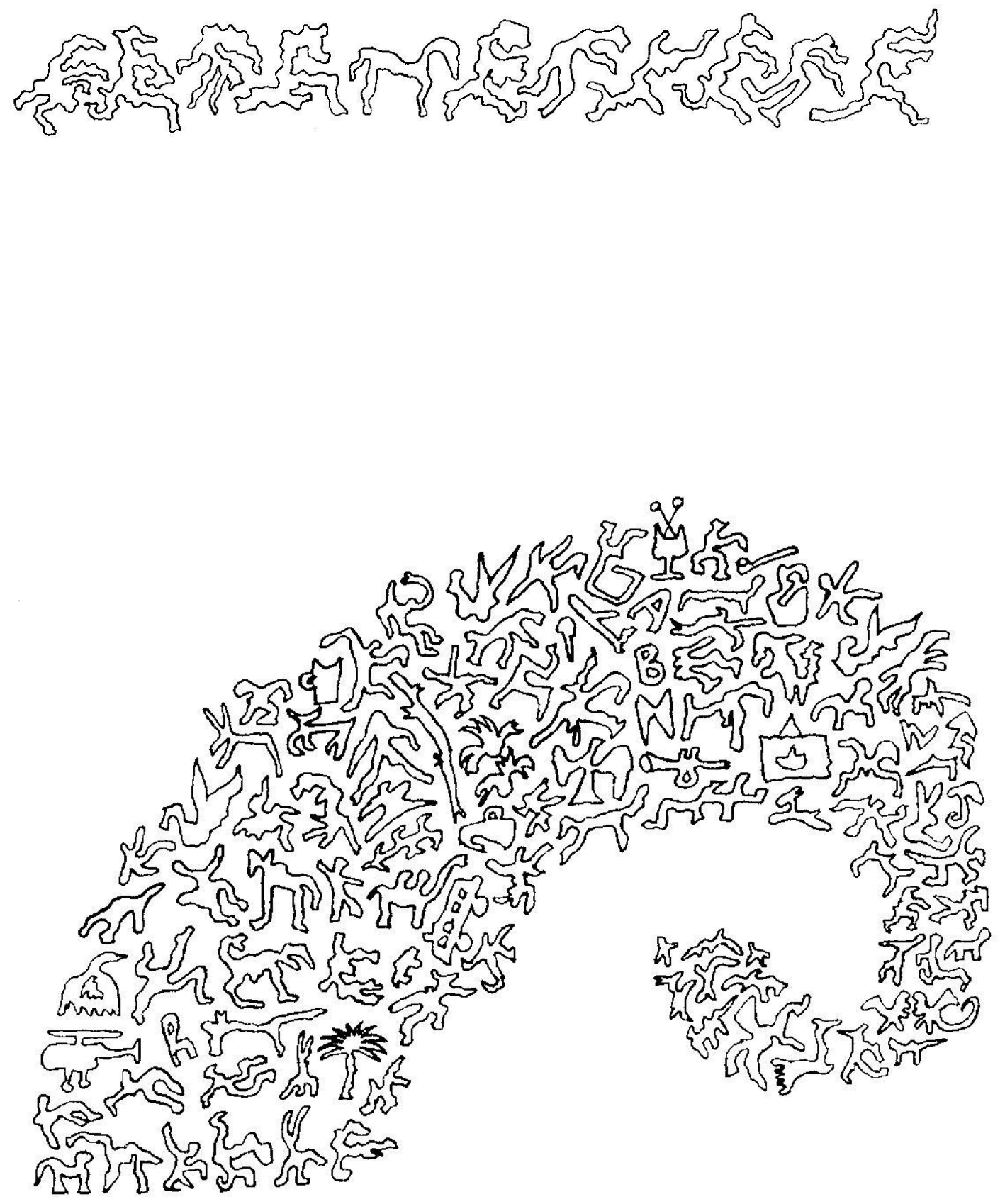
173

What is it? $\Omega$ atrás do trampolion (overlapping a tramp) (o que el o que ii)

Us gate (cat)

DD ten telefonema (watch my watch)

T6 surrupiando (disappearing into nothingness)

$\stackrel{2}{2}$ cobra triste (a sad sad snake)

10 vega so' (look at me)

as sol (the $27^{\text {th }}$ pregnant woman sunbathing)

25 na is wi pos ye e (scratching my back)

U. suicidal (upside down)

is aconteceu no ultimo verão (frog) 
174

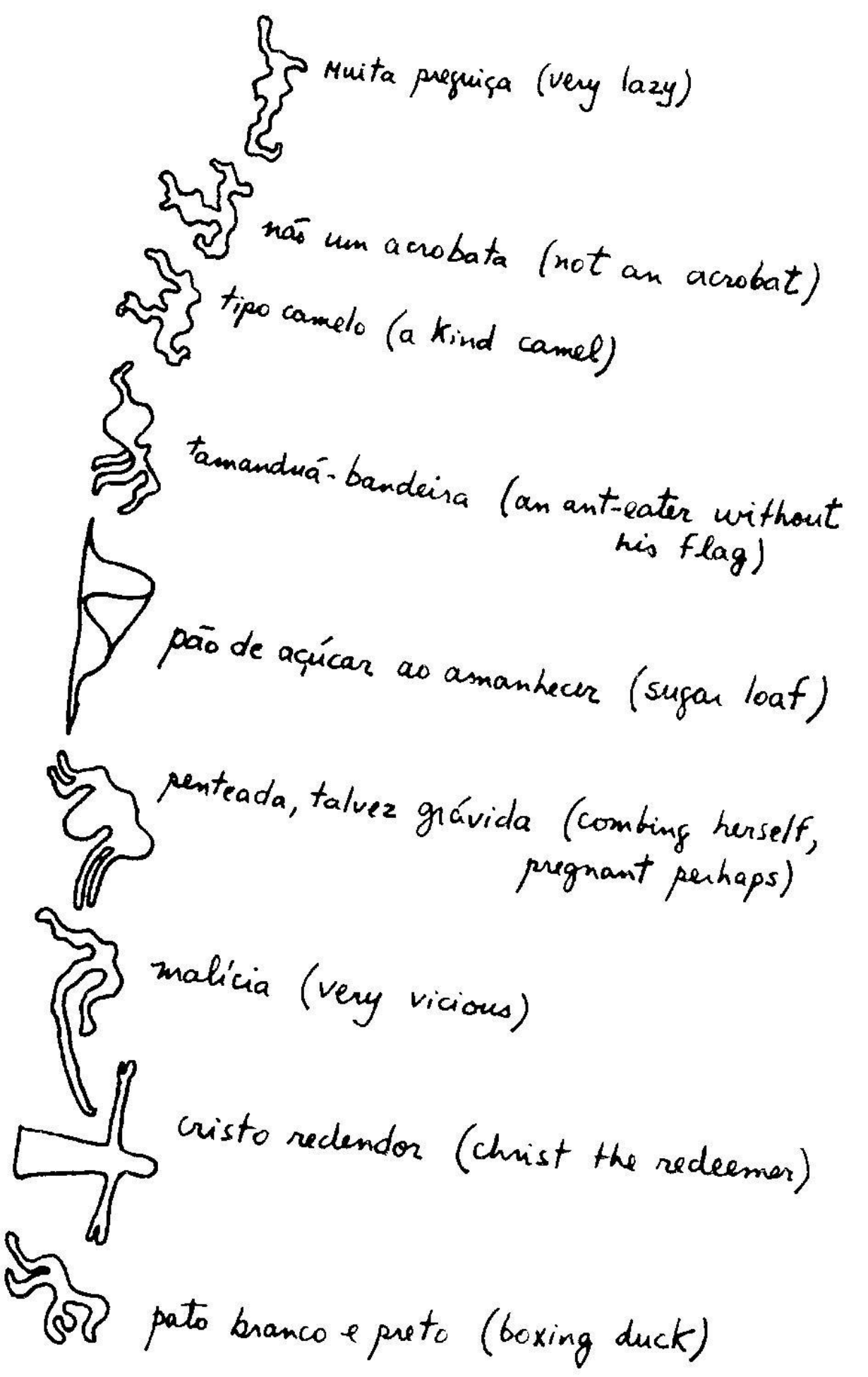




\section{Fragmentos}

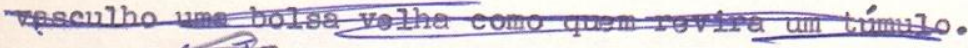

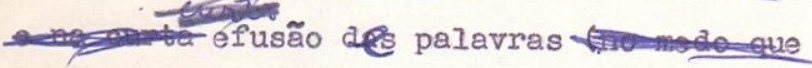

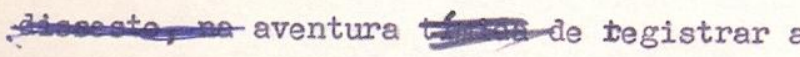

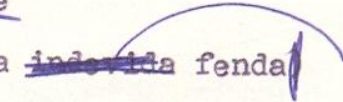

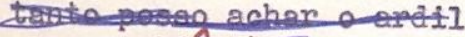

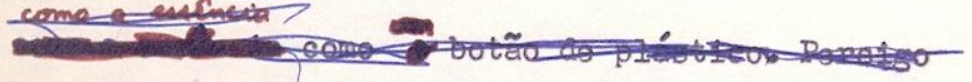

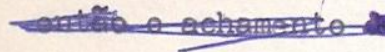

desistir da fluência

de todos os truques

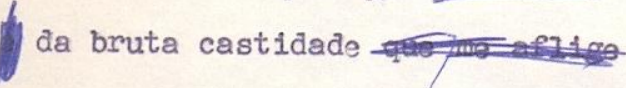

Tscrea corrandio eom saudade

(me reconheciam em versos naquele tempo)

peasporatquer coisa tua me lembre

a mãe

naquele tempo

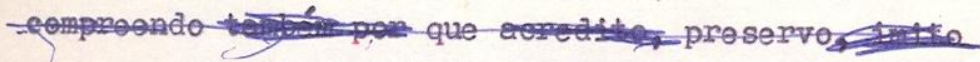

as mesmas formas da pureza recusada:

seì reside a dúvida

a pele que refaço 


\section{4 de maio de 1976}

Discussão na mesa do jantar. Asslinto, o vazemento que molhou o corredor. Mamãe acha que papai é um mole. Papal pergunta por que ela mesma não vai tratar do assunto. Não dizem tudo $\circ$ que pensam. Hamãe mandou atapetar qu̇ando papai viajava, surpresa. Há silência, eurlosidade de saber o desenlace.

Mamãe diz que projeton - fllme para mais duas turmas. fapai diz que queria tanto tocar órgão, ensaia, dedilha no ar. Pergunta de mamãe se ele já terminou o trabalho da blooh? linimos serenados pela tática de mútuos redesvios. Depois do jantar os homens descolam o tapete com ferramentas. Todos participam do alagamento. Escrevo in loco, sem literatura. 15 Penso na posteridade.

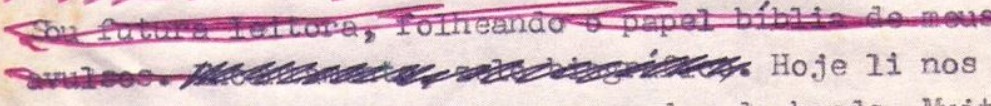
avulsos de Machado: regras para andar de bonds. Mhita uxk atonção a escarros, cuspes, catarros e peraigotos. 


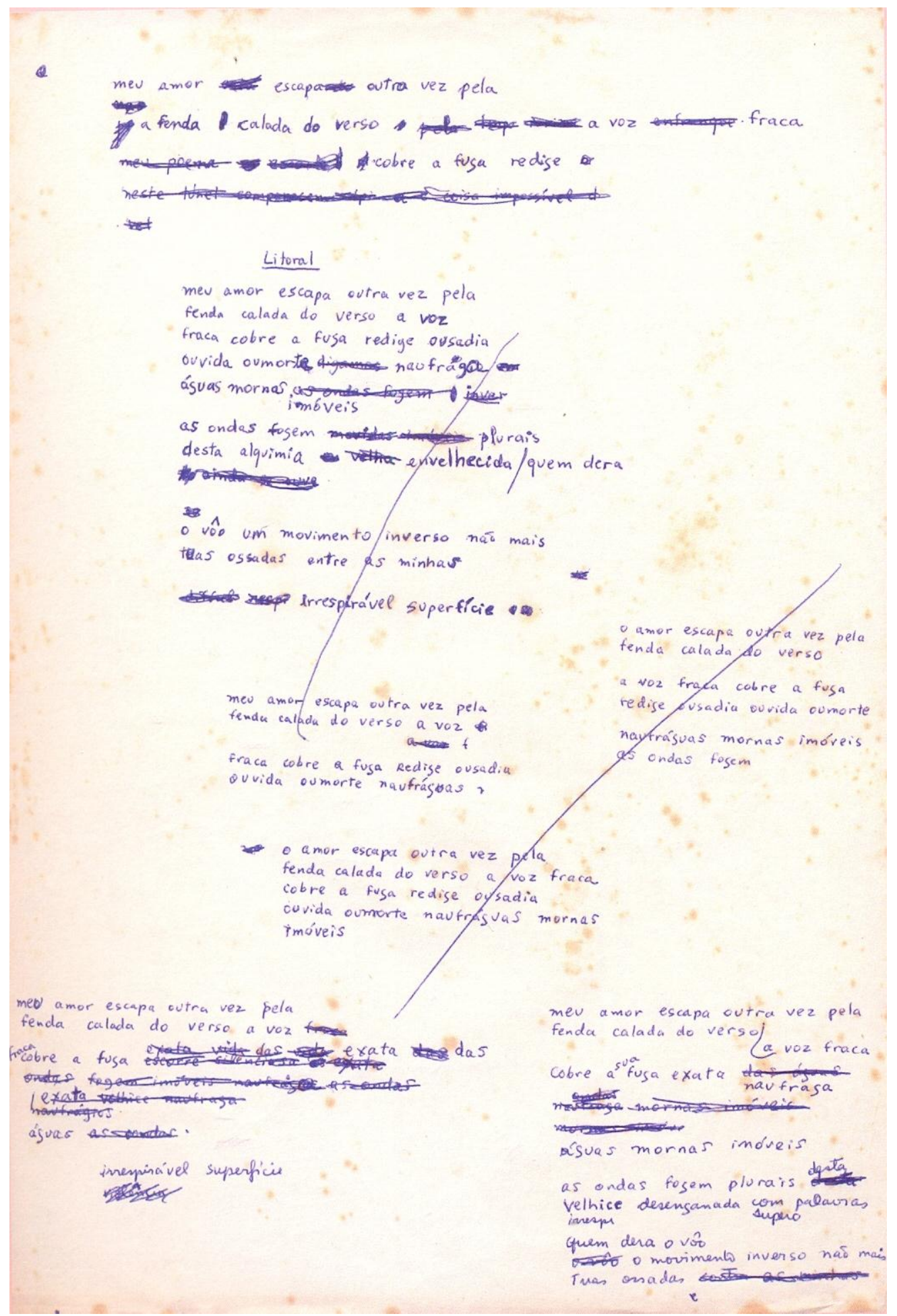


178

QVANDO EU NASCI.

UM Dois UM DOiS UM DO is UM DOiS

Mão sei/barra/Mao sei / bana

Mao sei/caimbio/Mco sei/cambio

voce me preocupa tant

quer les minhs caligrafis

quer dizer que eslou

TUDODOI

Resisto: TUDODÓi

Amanhá nós vamos necomecar tudo outre vez tudo ouths vez

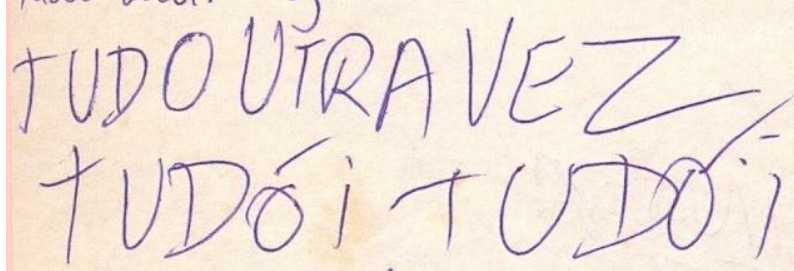

As lorestas ocupadas pier seres soforidissimos (elfos)

Voì li?

Voi vi?

Acabo de cicular em silencio 


\section{"Carta de despedida"}

eu me tenha iludido: eu me tenha 1ludido: a repetição é fundamental, meu caro. a repetição é fundamental, was eu me sinto um pouco assim assim, vamos embora, vamos dizer que tudo não passa, vamos dizer que medéia te espe ra: medéia tem um aspecto mais moderno do que se podia imaginar. ando tal como um hamster, corro pra lá e pra cá qual exatamente um hamster ( e não um hamster ferido). chega um ponto eu sinto falta. digamos que é hora de começar a escrever "as memórias". imaginárias memórias boreais. tudo tão antigamente sugestiשo. imaginá-lus auroras. munir-se de exemplos. contando-as criticamente. este projeto me atrai. o que é a metafísicar eu sinto que me desgarro. me desgarro, me des-garra rútila no portal. eu tenha me iludido:

espero qualquer chegada com uma frase: eu tenha me iludido. acho que vou me suicidar.

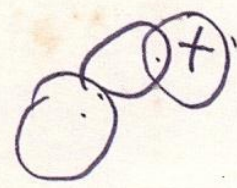

\section{espanto}




\section{Bibliografia:}

ARISTÓTELES. O homem de gênio e a melancolia - o problema XXX,I. Rio de Janeiro: Lacerda Editores, 1998.

ABRAHAM, K. Notas sobre as investigações e o tratamento psicoanalítico da psicose maníaco-depressiva e estados afins. (1911) In: Teoria Psicanalítica da Libido: Sobre o caráter e o desenvolvimento da libido. Rio de Janeiro: Imago Editora. 1970. 2009.

AGAMBEN, G. O que é o contemporâneo? e outros ensaios. Chapecó, SC: Argos,

AGAMBEN, G. Estâncias: a palavra e o fantasma na cultura ocidental. Belo Horizonte: Editora UFMG, 2007.

AULAGNIER, P. Um intérprete em busca de sentido (vol. I). São Paulo: Escuta, 1990.

BAAS, B.O desejo puro. Coleção Freudiana. Rio de Janeiro: Ed. Revinter, 2001.

BANDEIRA, M. Antologia Poética. Rio de janeiro: Nova Fronteira, 2001.

BARTHES,R.O prazer do texto. São Paulo: Ed. Perspectiva, 1987.

BARTHES,R. Fragmentos de um discurso amoroso. Rio de Janeiro: F. Alves, 1981.

BARTHES, R. A literatura e o direito de morte. In: A parte do fogo. Rio de Janeiro, Rocco, 1997.

BARTHES, R. Aula. São Paulo: Editora Cultrix, 2007.

BARTHES, R. A Morte do Autor. In: O Rumor da Língua. São Paulo: Martins Fontes, 2004.

BARTUCCI, G.(Org.) Psicanálise, literatura, estéticas de subjetivação.Rio de janeiro:Imago,2001.

BAUDELAIRE, C. As flores do mal. Tradução: Mário Laranjeira. São Paulo: Martin Claret, p.2011.

BENJAMIN,W. A Tarefa do Tradutor (Die Aufgabedes Übersetzers, GesammelteSchriften , IV.1, pp. 9 -21).Tradução Maria Filomena Molder.

BENJAMIN.W. A obra de arte na era de sua reprodutibilidade técnica. Magia e técnica, arte e política. São Paulo: Brasiliense, 1994. P.165-196.

BENJAMIN, W. O narrador: considerações sobre a obra de Nikolai Leskov. Magia e técnica, arte e política: ensaios sobre literatura e história da cultura. São Paulo: Brasiliense, 1994, p. 197-221 (Escrito em 1936 sob o título Der Erzähler: Betrachtungen zum Werk Nikolai Lesskows).

BIANCHI,H. O Eu e o tempo. São Paulo: Casa do Psicólogo,1993. 
BIRMAN,J. Arquivos do mal-estar e da resistência. Rio de Janeiro: Civilização Brasileira, 2006.

BIRMAN, J.O narcisismo e os impasses no processo psicanalítico. In: Freud e a interpretação psicanalítica. Rio de Janeiro: Relume-Dumará,1989.

BLANCHOT, M. Fragmentos de um discurso amoroso. Trad. Hortênsia dos Santos. Rio de Janeiro: F. Alves, 1981.

BLANCHOT, M. O livro por vir. Trad. Maria Virgínia Louro. Lisboa: Relógio d'Água, 1984.

BLANCHOT, M. O espaço literário. Rio de Janeiro: Rocco, 2011.

BOAVENTURA, C.T. A crítica de Ana Cristina César em Escritos no Rio. São Paulo: Linear B; 2008.

CARDOSO, M.R. Superego. São: Ed. Escuta, 2002.

CARVALHO, A.C. A poética do suicídio em Sylvia Plath. Belo Horizonte: Editora UFMG, 2003.

.A toxidez da escrita como um destino da sublimação em David Foster Wallace. In: Revista Psicologia USP. Vol.21. Num.3-2010, Julho/setembro. Universidade de São Paulo. Instituto de Psicologia. p.513-530.

. O método e a criação literária: uma visão psicanalíca. Revista de Psicanálise Pssychê. São Paulo: Centro de Estudos e Pesquisa e Pesquisa em Psicanálise da Universidade de São Marcos, ano VI,n. 09, 2002, p. 67-74.

. Freud borgeano, Borges freudiano: o pai, a cegueira e o recalque. Percurso, São Paulo: Instituto Sedes Sapientiae, ano VIII,n. 15, $2^{\circ}$. Semestre de 1995, p. 17-25.

. Escrita: remédio ou veneno? Revista de Psicanálise Percurso, São Paulo : Instituto Sedes Sapientiae, Ano IX, no. 18, $1^{\circ}$. semestre de 1997, p.79-86.

CASTELLO BRANCO, L.; SILVIANO BRANDÂO,R. Literaterras: as bordas do texto literário. São Paulo: Annablume, 1995.

CASTELLO BRANCO, L.;A branca dor da escrita: notas sobre a sublimação e o desastre em Emily Dickinson. Revista Destarte,V.1,n.1.Vitória, 1º. Semestre de 2002.

CÉSAR, Ana Cristina. Porthsmouth-Colchester. São Paulo: Duas cidades, 1989. . A teus pés. São Paulo: Brasiliense, 1992. (1ª Edição:1982)

Edição: 1985). .Inéditos e dispersos. São Paulo: Ed. Ática, IMS, 1998. (1 $1^{\mathrm{a}}$. Paulo: Ed. Ática; IMS, 1999.

Literatura não é documento. In: Crítica e tradução. São 
Correspondência Incompleta. Org. Armando Freitas Filho e Heloísa Buarque de Holanda. Rio de Janeiro: Aeroplano,1999.

Crítica e tradução. São Paulo: Instituto Moreira Salles,2008.

. Antigos e Soltos: poemas e prosas da pasta rosa. Org:

Viviana Bosi. São Paulo, São Paulo: Instituto Moreira Salles, 2008.

Ana Cristina César: poética. São Paulo: Companhia das letras, 2013.

CHASEGUET-SMIRGUEL, J. O ideal do Ego. Porto Alegre: Artes Médicas, 1992.

CINTRA, E.M.U. Sobre luto e melancolia: uma reflexão sobre o purificar e o destruir. In: ALTER - Revista de Estudos Psicanalíticos, v. 29 (1) 23-40. 2011.

CINTRA, E.M.U. Pulsão de morte e Narcisismo Absoluto: estudo psicanalítico da depressão. Tese de Doutorado. 2000. Pontifícia Universidade Católica.

COELHO JUNIOR, N. Intersubjetividade e corporeidade: dimensões da clínica psicanalítica.In: Dimensões da intersubjetividade. São Paulo: Escuta 2012.p.71-88.

DELOUYA, D. Entre Moisés e Freud: tratados de origem e de desilução do destino. São Paulo: Via Lettera Editora, 2000.

DELOUYA, D. Depressão, estação psique: refúgio, espera, encontro.São Paulo: Escuta: Fapesp, 2002.

DETHIVILLE, L. O direito ao segredo do self. Winnicott e-prints, São Paulo, v.5, n.2,2010. Disponible em http://pepsic.bvsalud.org/scielo.php?script=sci_arttext\&pid=S1679-

432X2010000200004\&lng=es\&nrm=iso >. accedido en 12 abr. 2014.

DERRIDA,J. Escritura e diferença. São Paulo: Editora Perspectiva. 1995.

DERRIDA, J. A farmácia de Platão. São Paulo: Iluminuras, 2005.

DICKINSON,E. Emily Dickinson: uma centena de poemas. São Paulo: Ed. Da Universidade de São Paulo. 1984.

FÉDIDA, P. L'absense. Paris:Galimard,1978.

Escuta, 1999.

Dos benefícios da depressão: elogio da psicoterapia. São Paulo: Ed. Depressão. São Paulo: Ed. Escuta, 1999.

FERENCZI, S. A criança mal acolhida e sua pulsão de morte. (1929) In: Obras Completas; vol. IV. 2a. edição. São Paulo: Editora WMF Martins Fontes, 2011.

A adaptação da família à criança. (1928) In: Obras Completas; vol.

IV. 2a.edição. São Paulo: Editora WMF Martins Fontes, 2011. 
Confusão de línguas entre os adultos e as crianças (1933). In:

Obras Completas;vol. IV. 2a. edição. São Paulo: Editora WMF Martins Fontes, 2011.

FELMAN, S. Educação e crise ou as vicissitudes do ensinar. Em Catástrofe e representação: ensaios. Org: Arthur Nestrovski, Márcio Seligmann-Silva. São Paulo: Escuta, 2000.

FIGUEIREDO, L.C. Palavras Cruzadas entre Freud e Ferenczi. São Paulo: Editora Escuta, 1999.

.Intersubjetividade, mundo interno e superego. In:Dimensões $d a$ intersubjetividade. São Paulo: Escuta, 2012.p.247-275.

Intransigência e criatividade em André Green. Ano 3, Março/2014. Disponível em: http://www.sig.org.br/_files/uploads/image/Num3_SiteArt1.pdf

FIGUEIREDO, L.C; COELHO JUNIOR, N. Figuras da intersubjetividade na constituição subjetiva: dimensões da alteridade. In: Dimensões da intersubjetividade. São Paulo: Escuta, 2012.

FLORENCE, J. (1994). As identificações. In: Maud Mannoni et al. As identificações na clínica e na teoria psicanalítica. (A. Roitman Trad.). Rio de Janeiro: Relume - Dumará. (Obra original publicada em 1987). p. 115-146.

FONTES, I. A construção silenciosa do ego corporal. ALTER - Revista de Estudos Psicanalíticos, v. 29 (2) 83-90, 2011.

FOUCAULT, M. A coragem da verdade. São Paulo: Martins Fontes,2011.

FOUCALT. M. A escrita de si. In: Ética, Sexualidade, Política. (Org.) Manoel Barros da Motta. Rio de janeiro: Forense Universitária, 2006.

FOUCALT, M. O que é um autor? In: Bulletin de la Societé Française de Philosophic, 63 ${ }^{\circ}$ ano, no 3, julho-setembro de 1969, ps. 73-104. (Societé Française de Philosophie, 22 de fevereiro de 1969; debate com M. de Gandillac, L.Goldmann, J. Lacan, J. d'Ormesson, J. Ullmo, J. Wahl.)

FRANÇA NETO, O. Identificação e culpa: questões éticas contemporâneas. Ágora (Rio J.) vol.8 no.1 Rio de Janeiro Jan./Jun, 2005.

FRANÇA NETO, O. Freud e a sublimação: arte, ciência, amor e política. Belo Horizonte: Editora UFMG, 2007.

FREUD, S. Projeto para uma psicologia científica(1950[1895]). In: Publicações pré-psicanalíticas e esboços inéditos. Rio de Janeiro: Imago, 1987. (Edição Standard Brasileira das Obras Psicológicas Completas de Sigmund Freud).

FREUD, S. Extratos dos doscumentos dirigidos a Fliess: "Rascunho G" (1950[1892-1899]). In: Publicações pré-psicanalíticas e esboços inéditos. Rio de Janeiro: Imago, 1987. (Edição Standard Brasileira das Obras Psicológicas Completas de Sigmund Freud). 
Delírios e sonhos na Gradiva de Jensen. (1907[1906]). In: . Delírios e Sonhos na "Gradiva" de Jensen e outros trabalhos. Rio de Janeiro: Imago, 1987. (Edição Standard Brasileira das Obras Psicológicas Completas de Sigmund Freud).

Escritores criativos e devaneios (1908[1907]). In:

Delírios e Sonhos na "Gradiva" de Jensen e outros trabalhos. Rio de Janeiro: Imago, 1987. (Edição Standard Brasileira das Obras Psicológicas Completas de Sigmund Freud).

Moral sexual "civilizada" e doença nervosa moderna (1908). In: _. Delírios e Sonhos na "Gradiva" de Jensen e outros trabalhos. Rio de Janeiro: Imago, 1987. (Edição Standard Brasileira das Obras Psicológicas Completas de Sigmund Freud).

estética (1913). In:

Interesse da psicanálise do ponto de vista da ciência da 1987. Totem e Tabu e outros trabalhos. Rio de Janeiro. Imago, 1987. (Edição Standard Brasileira das Obras Psicológicas Completas de Sigmund Freud).

Sobre o narcisismo: uma introdução (1914). In: . A história do movimento psicanalítico, artigos sobre a metapsicologia e outros trabalhos. Rio de Janeiro: Imago, 1987. (Edição Standard Brasileira das Obras Psicológicas Completas de Sigmund Freud).

Observações sobre o amor transferencial (Novas recomendações sobre a técnica da psicanálise III) (1914). In: __. O caso de Screber;Artigos sobre técnica e outros trabalhos. Rio de Janeiro: Imago, 1987. (Edição Standard Brasileira das Obras Psicológicas Completas de Sigmund Freud).

O instinto e suas vicissitudes (1915). In: . A história do movimento psicanalítico, artigos sobre a metapsicologia e outros trabalhos. Rio de Janeiro: Imago, 1987. (Edição Standard Brasileira das Obras Psicológicas Completas de Sigmund Freud).

Luto e melancolia (1917[1915]). In: A história do movimento psicanalítico, artigos sobre a metapsicologia e outros trabalhos. Rio de Janeiro: Imago, 1987. (Edição Standard Brasileira das Obras Psicológicas Completas de Sigmund Freud).

Conferência XXVI: A teoria da libido e o narcisismo (1917[1916-1917]). In: Conferências introdutórias sobre psicanálise (Parte III). Rio de Janeiro: Imago, 1987. (Edição Standard Brasileira das Obras Psicológicas Completas de Sigmund Freud).

O 'estranho'. (1919). In: . Uma neurose infantil. Rio de Janeiro: Imago, 1987. (Edição Standard Brasileira das Obras Psicológicas Completas de Sigmund Freud). 
Além do princípio do prazer (1920). In:

Além do princípio do prazer, psicologia de grupo e outros trabalhos. Rio de Janeiro: Imago, 1987. (Edição Standard Brasileira das Obras Psicológicas Completas de Sigmund Freud).

O ego e o id (1923). In: O ego e o id e outros trabalhos. Rio de Janeiro: Imago, 1987. (Edição Standard Brasileira das Obras Psicológicas Completas de Sigmund Freud).

O problema econômico do masoquismo (1924). In: . $O$ ego e o id e outros trabalhos. Rio de Janeiro: Imago, 1987. (Edição Standard Brasileira das Obras Psicológicas Completas de Sigmund Freud).

Neurose e Psicose(1924 [1923]). In: O ego e o id $e$ outros trabalhos. Rio de Janeiro: Imago, 1987. (Edição Standard Brasileira das Obras Psicológicas Completas de Sigmund Freud).

O humor (1927). In: . O futuro de uma ilusão, $O$ Malestar na civilização e outros trabalhos. Rio de Janeiro: Imago, 1987. (Edição Standard Brasileira das Obras Psicológicas Completas de Sigmund Freud).

Dostoievski e o parricídio (1928[1927]). In: O futuro de uma ilusão, O Mal-estar na civilização e outros trabalhos. Rio de Janeiro: Imago, 1987. (Edição Standard Brasileira das Obras Psicológicas Completas de Sigmund Freud).

(1933[1932]). In: Conferência XXXI - A dissecção da personalidade psíquica. Novas conferências introdutórias sobre psicanálise e outros trabalhos.Rio de Janeiro: Imago, 1987. (Edição Standard Brasileira das Obras Psicológicas Completas de Sigmund Freud).

Construções em análise (1937). In: Um estudo autobiográfico, inibições, sintoma e ansiedade e outros trabalhos. Rio de Janeiro: Imago, 1987. (Edição Standard Brasileira das Obras Psicológicas Completas de Sigmund Freud).

Esboço de Psicanálise (1940 [1938]). In: Moisés e o monoteísmo e outros Trabalhos. Rio de Janeiro: Imago, 1987. (Edição Standard Brasileira das Obras Psicológicas Completas de Sigmund Freud).

GARCIA-ROZA, L. A. Introdução à metapsicologia freudiana. (vol.1). Rio de Janeiro: Jorge Zahar,1996.

GERTRUDE, Stein. A autobiografia de Alice Toklas. Tradução: José Rubens Siqueira. São Paulo: Cosac Naiyf, 2009.

GREEN, André. A mãe morta. In: Narcisismo de Vida, Narcisismo de Morte. São Paulo: Escuta, 1988.

.A reserva do incriável. In: $O$ desligamento: Psicanálise, Antropologia e Literatura. Rio de Janeiro: Imago, 1994. 
O desligamento. In: $O$ desligamento: Psicanálise, Antropologia e Literatura. Rio de Janeiro: Imago, 1994.

- O duplo e o ausente. In: $O$ desligamento: Psicanálise, Antropologia e Literatura. Rio de Janeiro: Imago, 1994.

. A Pulsão de Morte na Teoria da Pulsão Sexual. In: GREEN, André [et al.]. A pulsão de morte. São Paulo: Ed. Escuta, 1988.

HOUAISS, A. Dicionário da língua portuguesa. Rio de Janeiro: Objetiva, 2001.

JAMISON, K. R. Touched with Fire: Manic-Depressive Illness and the Artistic Temperament. New York: Simon \& Schuster, 1993.

JAMISON, K. R. Uma mente inquieta. São Paulo: Martins Fontes, 2006.

JOSEPH, B. O vício pela quase-morte. In: Equilíbrio psíquico e mudança psíquica: artigos selecionados de Betty Joseph. Org: Feldman, M. e Spillius, E.B.Coleção Nova Biblioteca de Psicanálise. Rio de Janeiro: Imago Ed., 1992.

KAUFMANN, P. Dicionário enciclopédico de psicanálise: o legado de Freud a Lacan. Rio de Janeiro: Zahar Ed., 1996.

KELL, M.R. O tempo e o cão. São Paulo: Boitempo, 2009.

KLEIN, M. Amor, culpa e reparação. (1937) In: Amor, Culpa e Reparação e outros trabalhos. Rio de Janeiro: Imago, 1996.

KLEIN,M.O luto e suas relações com os estados maníaco-depressivos.(1940) In: Amor,Culpa e Reparação e outros trabalhos. Rio de Janeiro: Imago,1996.

KOFMAN, S. A infância da Arte: uma interpretação da Estética Freudiana. Rio de Janeiro: Relume Dumará, 1996.

KON, N. M. Freud e seu duplo. São Paulo: Editora da Universidade de São Paulo: FAPESP, 1996.

KRISTEVA, J.O Sol Negro- depressão e melancolia. Rio de Janeiro: Rocco,1989.

KRISTEVA,J. On the melancholic imaginary. In: New formations. Number 3 Winter, 1987.

KUPERMANN, D. Presença sensível: cuidado e criação na clínica psicanalítica. Rio de Janeiro: Civilização Brasileira, 2008.

. Humor, desidealização e sublimação na psicanálise IN: Psicol. clin. vol.22 no.1 Rio de Janeiro jun, 2010.

- Ousar rir: humor, criação e psicanálise sensível: cuidado e criação na clínica psicanalítica. Rio de Janeiro: Civilização Brasileira, 2003.

- Psicanálise e cultura: Utopias e poderes na história da psicanálise. In: Universos da psicanálise. Orgs: Kupermann, D. e Denise Rollemberg. Rio de Janeiro: Relume-Dumará: CCBB,1995. 
. Seria trágico... se não fosse cômico.(Orgs.)Abrão Slavutzky e Daniel Kupermann. Rio de Janeiro: Civilização Brasileira, 2005.

LACAN,Jacques. O estádio do espelho como formador da função do eu.(1949) In: Escritos.Rio de janeiro: Jorge Zahar Editor,1998.

LACAN,J. O seminário livro 7: A ética da psicanálise. Rio de Janeiro: Rocco, 1989.

LACAN, J. O seminário livro 8: A transferência. Rio de Janeiro: Rocco, 1989.

LAGE, I. Sublimação e idealização: os destinos de um conflito. Belo Horizonte: UFMG/FAFICH, 2008.184p. Dissertação de mestrado.

LAMBOTTE, Marie-Claude. O discurso melancólico: da fenomenologia à metapsicologia. Rio de Janeiro: Companhia de Freud Editora,1997.

LAMBOTTE, Marie-Claude. Estética da Melancolia. Rio de Janeiro: Ed. Companhia de Freud, 2000.

LAPLANCHE, Jean. Problemáticas III: A sublimação. São Paulo: Martins Fontes, 1989.

l'homme. Paris: PUF,1999.p.301-338.

. Sublimation et/ou inspiration.In: Entre seduction et inspiration:

A Pulsão de Morte na Teoria da Pulsão Sexual. In: GREEN, André et al. A pulsão de morte. São Paulo: Editora Escuta, 1988.

LAPLANCHE, J.; PONTALIS, J.-B. Vocabulário da Psicanálise. 10 ed. São Paulo: Martins Fontes, 1988.

LARANJEIRA, M. Poética da tradução. São Paulo: Ed. Da Universidade de São Paulo, 2003.

LIMA, Regina S. C. O desejo na poesia de Ana Cristina César: 1952-1983. São Paulo: Annablume, 1993.

LOFFREDO,A.M. Figuras da sublimação na metapsicologia freudiana. Revista Brasileira de Psicanálise- Vol. 45, n.1, 2011, p.51-62.

MALUFE, Anita C. Territórios Dispersos: a poética de Ana Cristina César. Paulo: Annablume; FAPESP, 2006.

MANNONI, O. “Eu sei, mas mesmo assim,...”. In: Chaves para o Imaginário. Trad. Ligia Maria Pondé Vassalo. Petrópolis: Vozes, 1973.

MANNONNI, O. As desidentificações. In: As identificações na clínica e na teoria psicanalítica. Maud Mannoni [et al]; organização, tradução e prefácio Ari Roitman. Rio de Janeiro: Relume-Dumará,1994.p.173-200.

MANNONNI, O. A desidentificação. In Um espanto tão intenso: a vergonha, o riso, a morte. Rio de Janeiro: Campus, 1992.

MARCOS,C. Resíduos do nada: a arte contemporânea e a subjetivação feminina. Revista Curinga no. 20. Belo Horizonte, Novembro de 2004. 
MASSA, E.S.C. Reflexos do objeto materno: do processo melancólico ao impulso suicida - as horas que separam duas mortes. Dissertação de mestrado- UFMG. Belo Horizonte, 2012.

METZGER, C.; SILVA JR. N. Sublimação e pulsão de morte: a desfusão pulsional. In: Revista Psicologia USP. Vol.21. Num.3-2010, Julho/setembro. Universidade de São Paulo. Instituto de Psicologia. p.567-584.

MEZAN, R. (1996). O símbolo e o objeto em Férenczi. In: Katz, C. S. (Org.). Férenczi: história, teoria, técnica. São Paulo: Ed. 34. p. 91-120.

MIJOLLA-MELLOR,S. Le choix de la sublimation. Paris: PUF, 2005.

Os ideais e a sublimação. In: Revista Psicologia USP. Vol.21. Num.3-2010, Julho/setembro. Universidade de São Paulo. Instituto de Psicologia. p.501512.

Psicanálise - Vol. 45, n.1. 2011.p.37-50.

Sublimação e prazer do pensamento. Revista Brasileira de

MIJOLLA-MELLOR,S; PONTALIS,J.B; NEYRAUT,M. L'autobiographie. Paris: Societéd'editon -Les Belles Lettres, 1988.

MOREIRA, A.C. A clínica da melancolia. São Paulo: Ed. Escuta, 2002.

MOREL, D. Ter um talento, ter um sintoma. Trad. Ana Maria Leandro e Lidia Aratenguy. São Paulo: Escuta, 1990.

MORICONI, I. Ana Cristina César: o sangue de uma poeta. Rio de Janeiro: Relume-Dumará,1996.

OLIVEIRA, M. C. A dor dorme com as palavras. São Paulo: Sete Letras, 2011.

PAULA, M.P. A identificação como efeito do processo tradutivo da sedução originária. Maringá, 2011. (http://www.ppi.uem.br/Dissert/PPIUEM_2011_Marina.pdf)

PELLION,F. Melancolía y verdade. Buenos Aires: Manantial, 2003.

PINHEIRO, M.T. Trauma e Melancolia. In: Katz, C. S. (Org.). Férenczi: história, teoria, técnica. São Paulo: Ed. 34.1996, p. 43-64.

PLAZA, M. A escrita e a loucura. Lisboa: Editorial Estampa, 1989.

PONTALIS, J.B. A melancolia da linguagem. Perder de vista: da fantasia de recuperação do objeto perdido. Rio de Janeiro: Jorge Zahar Editor.1988.

RECALCATI, M. As três estéticas de Lacan. Revista Opção Lacaniana, n.42. Janeiro de 2005.

RIBEIRO, P.C. C. O problema da identificação em Freud: recalcamento da identificação feminina primária. São Paulo: Escuta, 2000.

ROSENBLUM, Rachel.¿Se puede morir de decir? Sarah Kofman, Primo Levi. Psicoanálisis APdeBA- Vol. XXIV- N. 7/2-2002 
ROSENBERG, B. Masoquismo mortífero e masoquismo guardião de vida. São Paulo: Escuta, 2003.

ROUSSILLON, R. Primitive agony and symbolization. Londres: Karnac, 2011.

SCHNEIDER, M. Ladrões de palavras: ensaio sobre o plágio, a psicanálise e o pensamento. Tradução de Luiz Fernando P. N. Franco. Campinas: Editora da UNICAMP, 1990, 503 p. (Coleção Repertórios).

SEGAL, H. Arte e posição depressiva. In: Sonho, Fantasia e Arte. Rio de janeiro: Imago Ed., 1993.

SEGAL, H. Joseph Conrad e a crise da meia-idade. In: Psicanálise, Literatura e Guerra. Artigos 1972-1995. Org: John Steiner. Rio de janeiro: Imago Ed., 1998.

SEGAL, H. Salma Rushdie e o mar de histórias: Uma fábula não muito simples sobre a criatividade. In: Psicanálise, Literatura e Guerra. Artigos 1972-1995. Org: John Steiner. Rio de janeiro: Imago Ed., 1998.

SELIGMANN-SILVA. Um tradutor é um escritor da sombra? Variações sobre a ontologia da tradução. Texto originalmente apresentado como aula inaugural do Programa de Pós-Graduação em Estudos da Tradução da UFSC em 14 de março de 2011.

SELIGMANN-SILVA; NESTROVSKI, A. (Orgs). Catástrofe e representação: ensaios. São Paulo: Escuta, 2000.

SIGAL, A M. (2009). Formação do Eu: um estudo para ler o Estádio do Espelho. In: Escritos Metapsicológicos e Clínicos. São Paulo: Casa do Psicólogo. Disponível em: www.sedes.org.br/Departamentos/Psicanalise/formacao_do_eu_sigal.pdf

SILVA JR., N.; GASPARD, J-L. A iatrogênese da sublimação em três tempos da cultura. Revista Brasileira de Psicanálise- Vol. 45, n.1. 2011.p.75-88.

SILVA JR, N. A ficcionalidade da psicanálise. Hipótese a partir do inquietante em Fernando Pessoa In: Bartucci, G. (Org) Psicanálise, literatura e estéticas de subjetivação. Rio de Janeiro: Imago Ed., 2001.

SOUZA, C.E.S.F. A lírica fragmentada de Ana Cristina César. São Paulo: EDUC, 2010 .

SOUZA, P. C. (1999). As Palavras de Freud: O Vocabulário Freudiano e Suas Versões. São Paulo: Editora Ática.

SOLOMON, A. O demônio do meio-dia. Rio de Janeiro: Objetiva, 2002.

SÜSSEKIND, F. Até segunda ordem não me risque nada: os cadernos, rascunhos e a poesia-em-vozes de Ana Cristina César. Rio de Janeiro: Sette Letras, 1995.

SONTAG, S. Questão de ênfase: ensaios. Trad.: Rubens Figueiredo. São Paulo: Companhia das Letras, 2005.

TOLEDO, J. Dicionário de suicidas ilustres, Rio de Janeiro: Record, 1999.

TOROK, M.; ABRAHAM, N. A casca e o núcleo. São Paulo: Escuta,1995. 
TROCOLI, F. O retrato do artista como perda. In: Nina Virgínia de Araújo Leite e J.Guillermo Milán-Ramos. (Org.). EntreAto - o poético e o analítico. Campinas/SP: Mercado de Letras, 2011, v., p. 289-295.

VERAS, V. Atos de fala e escrita em cenas da tradução. In: EntreAto - o poético e o analítico. Nina Virgínia de Araújo Leite e J.Guillermo Milán-Ramos. (Org.). Campinas/SP: Mercado de Letras, 2011, p. 43- 52.

VERTZMAN, J. O observador do mundo: a noção de clivagem em Ferenczi. In: Revista Ágora v. V n. 1 jan/jun 2002 59-78

VERZTMAN, J. A melancolia e o olhar: uma clínica contemplativa. In: Dimensões da intersubjetividade. São Paulo: Escuta 2012.p.105-124.

VERTZMAN, J. PINHERO, T., HERZOG, R. Vergonha, culpa, depressão contemporânea e perdão (Projeto de Pesquisa do NEPECC-UFRJ). In: Comunicação de pesquisas. Ano I, Edição I. $2^{\circ}$. Semestre de 2009. Disponível em: http://www.uva.br/trivium/edicao1/comunicacao-de-pesquisa.htm

VERTZMAN,J. PINHERO, T., HERZOG, R. Sofrimentos narcísicos. Rio de Janeiro: Cia de Freud: UFRJ; Brasília, DF: CAPES PRODOC, 2012.

WINNICOTT, D.W. O brincar e a realidade. Rio de Janeiro: Imago, 1975.

Porto Alegre: Arte Médicas Sul, 1994.

O medo do colapso (1963). In: Explorações psicanalíticas. Explorações psicanalíticas. Porto Alegre: Artes Médicas, 1994. Da pediatria à psicanálise. Rio de Janeiro: Imago, 2000.

WHITMAN, W. Folhas da relva. Tradução: Geir Campos. São Paulo: Ed. Brasiliense, 1989. 